\title{
Political Reconciliation
}

Andrew Schaap

$\mathrm{PhD}$ in Politics

The University of Edinburgh

February 2003 


\section{Contents}

$\begin{array}{ll}\text { Declaration } & 4\end{array}$

$\begin{array}{ll}\text { Abstract } & 5\end{array}$

$\begin{array}{ll}\text { Abbreviations } & 7\end{array}$

$\begin{array}{lr}\text { Preface } & 9\end{array}$

$\begin{array}{lr}\text { Introduction } & 13\end{array}$

1. Reconciliation and Politics $\quad 24$

1.1 The legacy of grave state wrongs 25

1.2 Political inadequacy of restorative reconciliation 30

1.3 The risk of politics 33

$\begin{array}{ll}1.4 \text { The politics of reconciliation } & 37\end{array}$

2. Toleration $\quad 45$

2.1 The public good of security $\quad 46$

2.2 The limited horizon of human understanding 51

2.3 Limited politics $\quad 57$

2.4 The limit of toleration $\quad 65$

$\begin{array}{ll}\text { 3. Recognition } & 71\end{array}$

3.1 The irreducibly social good of identity $\quad 72$

$\begin{array}{ll}3.2 \text { Struggle for recognition and fusion of horizons } & 78\end{array}$

3.3 The anti-political moment of recognition 84

$\begin{array}{ll}3.4 \text { The dilemma of recognition } & 90\end{array}$ 
$\begin{array}{lr}\text { 4. Worldliness } & 97\end{array}$

4.1 The world disclosing potential of politics 98

4.2 The risk and promise of action $\quad 107$

$\begin{array}{ll}4.3 \text { Reflective judgement } & 117\end{array}$

5. Political Reconciliation 126

5.1 Beyond realism, toleration, recognition $\quad 127$

5.2 The political (im)possibility of reconciliation 134

6. Constitution 139

6.1 Between past and future $\quad 140$

6.2 Beginning 145

6.3 Promising "never again" 152

6.4 "We the people" 159

$\begin{array}{ll}\text { 7. Forgiveness } & 165\end{array}$

7.1 Setting aside resentment 166

$\begin{array}{ll}7.2 \text { Inadequacy of reason and necessity } & 170\end{array}$

$\begin{array}{ll}\text { 7.3 Political grounds for forgiveness } & 174\end{array}$

$\begin{array}{ll}7.4 \text { Amnesty, amnesia and anamnesis } & 179\end{array}$

$\begin{array}{lr}\text { 8. Responsibility } & 185\end{array}$

8.1 Guilt and denial $\quad 186$

8.2 Good men and good citizens $\quad 190$

8.3 Shame and sentimentality 194

8.4 Apology, reparation and the passage of time 201

9. Remembrance 208

9.1 Truth and politics 209

9.2 The redemptive power of narrative $\quad 214$

9.3 The judgement of history 220

9.4 Commemoration $\quad 225$

$\begin{array}{ll}\text { Conclusion } & 233\end{array}$

$\begin{array}{lr}\text { References } & 239\end{array}$ 


\section{Declaration}

I declare that:

a) this thesis has been composed by me

b) this work is my own

c) this work has not been submitted for any other degree or professional qualification, except for sections 8.1, 8.2 and 8.3, which contain revised material from my dissertation for the MSc (by research) in Social and Political Theory, The University of Edinburgh, 2000.

Andrew Schaap

3 June 2003 


\section{Abstract}

In this study in political theory I develop a political conception of reconciliation. In the late twentieth century, the concept of reconciliation became prominent in the political discourse of many polities divided by grave state wrongs. Reconciliation is an inherently political aspiration since it invokes a "we" to underwrite the legitimacy of shared public institutions. Yet the logic of reconciliation, which tends toward harmony and closure, also seems at odds with politics, which invariably entails plurality and conflict.

The work of Carl Schmitt provides a point of departure for considering the political nature of reconciliation and defining the problem of how a relation of enmity might be transformed into one of civic friendship. In the first half of this thesis I consider the liberal ideal of toleration (as articulated by John Locke) and the communitarian ideal of recognition (as articulated by Charles Taylor) as political ethics that might animate reconciliation. Against toleration and recognition, I turn to Hannah Arendt's ethic of worldliness to develop a theory of political reconciliation. Reconciliation, on this account, entails a difficult mode of interaction between former enemies that seeks to enclose both within a common horizon of understanding while affirming the possibility of calling any such shared horizon into question.

In the second half of the thesis, I draw on the interdisciplinary literature surrounding transitional justice to develop this theory of political reconciliation. I consider the implications of Arendt's ethic of worldliness (outlined in the first half of the thesis) for how we should think about four key issues confronting societies divided by past wrongs: the constitution of a political association that might accommodate former enemies; political grounds for forgiveness; the collective responsibility of those implicated in state 
wrongs and; coming to terms with the past through remembrance of these wrongs.

Two central arguments recur throughout the thesis. First, we should affirm reconciliation as an aspiration that sustains politics by framing an encounter between enemies in which they might debate the possibility and terms of their association. Yet, we must also invoke politics to resist the tendency inherent in the logic of reconciliation to bring to a close what should remain open, incomplete, contestable. Second, and following from this, in conceiving reconciliation politically we must reverse the order of our moral thinking. It is a political mistake to presuppose a common moral community that must be restored between those alienated by past wrongs. Political reconciliation would never get off the ground if it required agreement on shared norms and the nature of wrongdoing in order to initiate the 'return' of the wrongdoers to community with those wronged. Rather, it must begin with the constitution of a space for politics through the invocation of a "we" and proceed from this faith in a community that is notyet toward the possibility of a shared understanding of what went before. 


\section{Abbreviations}

\section{Hannah Arendt}

BPF - Between Past and Future

CR - Crises of the Republic

EJ - Eichmann in Jerusalem

EU - Essays in Understanding

$\mathrm{HC}$ - The Human Condition

JP - The Jew as Pariah

LKPP - Lectures on Kant's Political Philosophy

LM I - Life of the Mind 1: Thinking

LM II - Life of the Mind 2: Willing

MDT - Men in Dark Times

OR - On Revolution

OT - The Origins of Totalitarianism

\section{Karl Jaspers}

QG - The Question of German Guilt

\section{John Locke}

E - An Essay Concerning Human Understanding

PE - Political Essays

L - 'A Letter Concerning Toleration'

$\mathrm{T}$ - Two Treatises of Government

\section{Carl Schmitt}

CP - The Concept of the Political

PT - Political Theology 


\section{Charles Taylor}

EA - The Ethics of Authenticity

HMS - Hegel and Modern Society

PA - Philosophical Arguments

PP1 - Philosophical Papers 1: Human Agency and Language

PP2 - Philosophical Papers 2: Philosophy and the Human Sciences

$\mathrm{RS}$ - Reconciling the Solitudes

SS - Sources of the Self 


\section{Preface}

The beginning and completion of my tertiary education roughly coincided with two public spectacles: the fall of the Berlin wall and the attacks on the World Trade Centre. That both events were of great significance could not be doubted by those who watched as they were broadcast around the world. However, what their implications were for the various human societies that cover the globe became a subject of speculation and debate. While it was widely understood that the fall of the Berlin wall signalled the end of the cold war, the announcement that it meant the end of ideology and the beginning of a new world order tended to be met with hope or fear according to one's likely place in that order. Following the attacks on the twin towers it was widely reported that the world could never be the same again. What changed, exactly, remains unclear. What is apparent is that it started off a new war (and a new kind of war) against a different idea: not communism this time but terror. Only with hindsight will we be able to judge its significance for the world we inhabit.

This thesis is very much a product of the time between these two events - the epilogue to the "short twentieth century" - during which societies around the world struggled to readjust to changed political circumstances. For many, this was perceived as an opportunity for a new beginning. In several parts of the world, old conflicts that had been fuelled by a "cold" war came to end. Authoritarian regimes collapsed. Insurgents capitulated. But new conflicts also emerged with the resurgence of ethnic divisions within polities previously held together by communist regimes. With democratisation in countries such as South Africa and Chile, successor regimes were confronted by the problem of how to reckon with the legacy of grave state wrongs, which continued to divide the polity. 
In this context, "reconciliation" became an important objective of public policy. Reconciliation suggested dealing with past wrongs in a way that might promote national unity and open the way for a more peaceful future. Most controversially, the ideal of reconciliation was sometimes invoked to legitimate provision of amnesty to perpetrators of political violence. But reconciliation was not only pursued in new democracies. In settler societies such as Australia, the memory and continuing impact of the wrongs of colonisation continued to undermine the legitimacy of the political association by calling into question the basis of the "we" on which it was founded. Reconciliation became a watchword for the desire for a final settling of accounts that might enable us to leave the past behind and face the coming millennium with the hope for a more inclusive and just society.

In the universities, these events led to the development of an interdisciplinary literature in transitional justice. Initially the literature was dominated by legal theorists and political scientists concerned with the choices successor regimes must make in balancing the demands of retributive justice with the consolidation of democracy. There was also much interesting work carried out by anthropologists in relation to the exhumation of human remains and the impact of widespread state violence on society. However, the emergence of reconciliation as a central term of political discourse, especially as it was promulgated by the Truth and Reconciliation Commission in South Africa, soon attracted the attention of theologians and, eventually, philosophers and political theorists.

Coinciding with this attention to transitional justice was a growing interest among political theorists in the work of Hannah Arendt. With the end of the cold war, there was some disaffection with the modes of theorising and categories of understanding employed by political philosophers. Many questioned the curiously apolitical character of both liberal and socialist theories, which seemed inadequate in the face of what was actually at stake in many of the political conflicts of a changed world. Arendt's work offered an important corrective to this tendency, a basis for developing a more political approach to thinking about politics. This interest in Arendt also often filtered into the literature on transitional justice. For she is the only significant political theorist to accord forgiveness a central role in politics. Moreover, her account of narrative and the possibility of a 
redemptive catharsis through the public telling of stories proved attractive to advocates of truth commissions. Yet the many scattered remarks on Arendt within the literature on transitional justice are typically made only in passing and left underdeveloped.

In this thesis I draw these two literatures together and bring their related preoccupations to bear on each other: namely, what is "reconciliation"? And what is "the political"? As will become clear, I think that Hannah Arendt's work is invaluable for contemplating both of these issues and I appropriate it here in order to formulate a political conception of reconciliation. In the first half of the thesis, I introduce Arendt's ethic of worldliness as a framework for thinking about reconciliation in contrast to the ideals of toleration and recognition, suggested by the liberal and communitarian traditions. In the second half of the thesis I develop this concept of politics in relation to a nest of issues that the problem of reconciliation poses for political theory.

Since the terrorist attacks on the United States, concern about reconciliation seems to have been firmly displaced by concern about security, the hope for greater social trust and harmony overcome by fear of an enemy that cannot and ought not to be trusted. For the time being, reconciliation seems to be off the agenda. Yet, regrettably, the continuing perpetration of grave state wrongs (not least those which "we" in "the West" are implicated in) suggests that the need for sustained thinking about political reconciliation remains as urgent as ever.

I have benefited greatly from the support, encouragement, criticism and intellectual stimulation of many people during the course of my postgraduate studies at the University of Edinburgh. I am grateful to my supervisors, Kimberly Hutchings and Emilios Christodoulidis, who have taught by example what good philosophy and scholarship is. Christodoulidis's work on reconciliation and constitutionalism is frequently cited in this thesis. Hutchings' influence, while more subterranean, is no less pervasive. Both have shaped my thinking on this subject to an extent that cannot be adequately acknowledged. Thanks are also due to Jane Astbury, Zenon Bankowski, Christopher Bennett, Keith Breen, Bregham Dagleish, Allyn Fives, Duncan Forrester, Iseult Honohan, Russell Keat, Hilary Lawson, 
Mianna Lotz, Claire Moon, Thomas Moore, Jeffrey Prager, Laura Reagan, Julian Reid, Bert van Roermund and Claire Sutherland, all of whom have commented on my work at various stages of its development.

I acknowledge the financial support of the Faculty of Social Sciences at the University of Edinburgh, which provided me with a Postgraduate Research Studentship and that of the Committee of Vice Chancellors and Principals of the Universities of the United Kingdom, which provided an Overseas Research Student Award. Without this support I would not have undertaken a postgraduate degree. I am also grateful to Tony Coady and the Centre for Applied Philosophy and Public Ethics at the University of Melbourne for providing me with office space and a congenial environment in which to complete the thesis. My thanks to Hilary for proof reading the manuscript, for her financial support and for her loving and intellectual companionship throughout my (many) years as a student. 


\section{Introduction}

In an early [1948] essay, Hannah Arendt writes of the 'factual territory' onto which the crimes of the Nazi regime have driven Germans and Jews (EU: 212-216). Auschwitz opened up an abyss, on the one side of which stand the Germans in their complicity, which the Nazis 'consciously planned and realised'. On the other side stand the Jewish people in the 'blind hatred, created in the gas chambers.' In order to resist being drawn into this abyss of eternal hatred and perpetual guilt, she insists, both peoples must refuse to accept the facts of the world created by Nazi crimes as 'necessary and indestructible.' As Mary Dietz (2000: 94) discusses, the theme of this factual territory is 'conspicuously absent' and therefore 'saturatingly present' in Arendt's affirmation of politics as the highest activity of human beings in The Human Condition. In contrast to the holes of oblivion into which the victims of the Nazis were made to disappear, Arendt presents the good polity as a space of appearance. With her idealised image of the ancient Athenian polis, then, Arendt presents a 'healing illusion and a disruptive countermemory' according to which we might 'reach over the historical abyss created by Auschwitz, and break the mastery of the Holocaust' (Dietz 2000: 100). It is in this spirit of interpretation that I draw on Arendt's work, in this thesis, to develop a political conception of reconciliation.

What is at stake as a consequence of the unprecedented crimes perpetrated by the Nazis, Arendt suggests, is humanity itself. This humanity does not derive from a universal capacity that is part of our nature. Rather, it is an artificial achievement. We realise our humanity through public action and speech by which we share our experience of the world with others. 'We humanise what is going on in the world and in ourselves only by speaking of it, and in the course of speaking of it we learn to be human' (MDT: 25). Totalitarianism threatens this humanity by seeking to eliminate human spontaneity itself, our freedom to imagine how things might otherwise be, to 
call the world into question, to do the unprecedented. Consequently, the inhumanity of the death camps cannot be grasped by attending to the cruelty of the perpetrators or suffering of the victims. For what distinguishes a crime against humanity from other violence is not the barbarity of the violence itself, which, after all, is common throughout history. Rather, it is that it involves 'an attack upon human diversity as such', an attempt to eliminate the plurality that inevitably emerges whenever human beings come together to act and speak about the world they share in common (EJ: 268-269). Thus, Arendt invokes not universal human rights but politics as a remedy against the inhumanity of the modern genocidal impulse.

In 1959 Arendt accepted the Lessing Prize of the Free City of Hamburg. She accepted this honour with gratitude before her German audience, but also with an unusual public reflection on her personal background as a Jew forced to flee Germany by the Nazis. In her extraordinary acceptance speech (MDT: 3-31), she explores the possibility of resisting the Nazi legacy of guilt and hatred by juxtaposing the ideal of friendship exemplified by Gotthold Lessing against the 'weird irreality of worldlessness' that prevailed among both Germans and Jews during the period of Nazi rule. What Arendt admires in the eighteenth century dramatist and literary critic is not so much his tolerance of religious difference (and of Jews, in particular) but his 'passionate openness to the world and love of it.' Lessing's friendship was demonstrated in his 'vigilant partiality' - his readiness to judge, to take sides for the sake of the world and his gladness for plurality, for the 'infinite number of opinions that arise when men discuss the affairs of this world' (MDT: 26).

For Arendt, Lessing's greatness as a thinker was due not to his recognition of the limits of human knowledge (that there can be no absolute truth in human affairs that is self-evident to all) but his gladness for this. Lessing preferred the freedom to form and express an opinion to the compulsion of reason. Indeed, he would willingly sacrifice truth for the sake of friendship since the reign of truth in the world would result in the loss of politics. And Lessing knew that the inexhaustible richness of human discourse is infinitely more significant and meaningful than any One Truth could ever be' (BPF: 233-234). Arendt illustrates the point by supposing that if it could be scientifically proved that one race was, after all, inferior to 
another, Lessing would reject this truth outright - not by invoking the commandment against murder, but on the grounds that accepting such a truth would not be worth the sacrifice of a single friendship between two people (MDT: 29).

For Arendt, there is a close relationship between friendship and humanity because friendship is based on an 'openness to others' and a 'pleasure in the other person and what he says' (MDT: 15). As such friendship calls for more than tolerance; it entails a passionate and potentially agonistic encounter with others. It presupposes a willingness to engage in an incessant discourse in which difference and lack of consensus is understood not as an obstacle to communication but a precondition for it. For the significance of events enacted in the world only becomes apparent through the revelation of the diverse perspectives its inhabitants bring to bear on these. Our sense of reality depends on the disclosure of the world as an object held in common but perceived from a multitude of perspectives. In testifying to how the world seems to him, an actor initiates a relationship with those he addresses. The commonness of the world is not merely revealed, then, but constituted through politics since each perspective brought to bear on the world comes to form part of the inter-subjective reality we inhabit. Friendship thrives on the 'intensified awareness of reality' that arises from such political inter-action.

By contrast, with each person's withdrawal or retreat from the public sphere 'an almost demonstrable loss to the world takes place.' For 'what is lost is the specific and usually irreplaceable in-between which should have formed between this fellow and his fellow men' (MDT: 4-5). What Arendt refers to as 'dark times' occur when there is widespread withdrawal from the world. A strange irreality ensues because our 'common sense' of the world (our sense of its commonness) is diminished. During the dark time of Nazism, the loss of world among Germans was reflected in the phenomena of 'inner migration', according to which many people withdrew from public life into themselves. Reporting on the aftermath of Nazi rule in Germany in 1950, Arendt observed that the experience of totalitarianism seemed to have robbed all Germans of 'spontaneous speech and comprehension' (EU: 253). The profound awkwardness with which they struggled when confronted with the past in the post-war era was due not only to their unavoidable 
complicity but the loss of common sense that resulted from the inner migration.

By contrast, Jews did not withdraw but were forcibly excluded from the world. The experience of common persecution gave rise to fraternity among them. Yet this also involved a worldless form of togetherness. When the possibility of openness to and trust in the world is closed off, fraternity becomes a bulwark against a hostile environment as people huddle together for mutual support against the pressure of persecution. While fraternity often produces a genuine warmth of human relationships, however, it dissolves the 'interspace' between persons. In this situation, what is shared in common is no longer a world perceived from diverse perspectives but an identity predicated on a common situation. While the high level of consensus and kindliness experienced between members of a persecuted group can be exhilarating, however, it is ultimately unpolitical. For a oneness predicated on an identification among co-sufferers replaces the sensation of a world shared in common. This political irrelevance of fraternity is the reason why the 'humanity of the insulted and injured has never yet survived the hour of liberation by so much as a minute' (MDT: 16-17).

Just as fraternity cannot sustain a world in common, so Arendt rules out compassion as a humanitarian response through which a common world might be restored between wrongdoers and wronged. Compassion is a natural affect, a form of co-suffering, that touches us at the sight of the other's suffering. Yet, this feeling for our fellows is passive (for it is something that we suffer rather than do) and so cannot reveal the commonness of the world. Compassion is unpolitical because it seeks a direct relationship between persons based on fellow feeling rather than one mediated by the world. As such, it tends to 'shun the drawn-out wearisome processes of persuasion, negotiation, and compromise' that characterise politics (OR: 86-87). Moreover, since compassion can only comprehend the particular it becomes distorted into sentimentality when generalised to a collective (MDT: 19). When the boundlessness of such a sentiment is enjoyed for its own sake it leads to a peculiar insensitivity to 'reality in general and the reality of persons in particular' (OR: 90). ${ }^{1}$

${ }^{1}$ Arendt's remarks on compassion are controversial, especially with regard to the failings of
the French Revolution. For an opposing perspective see Nussbaum (1996). However, within 
In contrast to inner migration, fraternity and compassion, friendship is political because it depends on sharing joy rather than suffering. While suffering tends toward muteness and isolation, the enjoyment of others' company inspires dialogue and debate. While friendship is predicated on care for what is particular about the other, however, this does not necessarily entail indifference to her identity. In the midst of persecution it would be inadequate for a German and a Jew to declare friendship based on their common humanity. Such a response would be entirely unworldly since it would evade the reality of their situation. Rather, they would have to say to each other, 'A German and a Jew, and friends'. Only where such a friendship is sustained 'without false guilt complexes on the one side and false complexes of superiority or inferiority on the other, [would] a bit of humanness in a world become inhuman [be] achieved' (MDT: 23). To reject outright the identifications of a hostile world is to deny reality altogether. For whether one accepts or denies such identifications, they remain constitutive of a reality in which one lives and moves.

Taken in the context of her other work, Arendt's reflections on Lessing and 'humanity in dark times' suggest the outlines of a theory of political reconciliation. They suggest, that is, how members of a divided society might resist the legacy of grave state wrongs by turning to politics. On this account, rather than trying to surmount politics with compassion, political reconciliation would be mediated by the world that lies between former enemies. Against the certainty of moral reasoning, the possibility of political reconciliation would depend on the contestability of opinions. Rather than seeking to 'restore' a unity predicated on a common identity, political reconciliation would presuppose a plurality of potentially incommensurable perspectives - not only between the communities to which perpetrators and victims belong but among them. Rather than being sustained by the fraternal warmth of shared suffering, reconciliation might be realised through common enjoyment of the world. Instead of the benevolent indifference of toleration, political reconciliation would entail a willingness to engage others in a passionate and often agonistic discourse about the world we share in common with them. While it would require acknowledging those identities

the particular context with which we are concerned, I find Arendt's warning that the politicisation of compassion tends to pervert it into sentimentality persuasive. We will return to this issue in 8.3 . 
that are constituted and sustained by a history of enmity it would also require that we remain attentive to the difference in the other that exceeds her identity.

Drawing on this Arendtian account of politics, then, I will argue in this thesis that if reconciliation is to be political it cannot be conceived in terms of an ahistorical ideal of harmony or consensus according to which discord and antagonism would be stilled once and for all. Rather, it must be understood as a striving for a sense of commonness that might be disclosed from the clash of perspectives we bring to bear on the world in our historical relation to each other. As such, reconciliation would not be about transcending the conflicts of the past by striving for social harmony. Rather, reconciliation would condition the possibility of politics by framing a potentially agonistic clash of world views within the context of a community that is "not yet."

In order to elaborate this political theory of reconciliation, I begin by considering Carl Schmitt's (ultimately reductive) concept of the political as defined by the ever-present possibility of the friend-enemy relation. Schmitt is important for thinking about reconciliation on two counts. First, by drawing our attention to the inherently conflictual nature of politics, Schmitt helps us to recognise the politics of reconciliation and, hence, the political inadequacy of a restorative conception of reconciliation. Rather than recognising community as the fragile achievement of political inter-action, such an account presupposes a moral community between perpetrator and victim that must be restored. This presupposition of community depoliticises the terms within which reconciliation is to be enacted by representing them as necessary and incontestable. Second, by drawing our attention to the risk of politics - the possibility that political inter-action will not lead to reconciliation but will confirm a relation of enmity - Schmitt helps to delineate the problem that a reconciliatory politics must address. That is, not how to restore community between alienated co-members, but how to transform a relation of enmity into one of civic friendship. This problem provides the context for the first half of the thesis, in which I consider, in separate chapters, toleration, recognition and worldliness as alternative ethics that might animate political reconciliation. 
I turn to the work of John Locke, in chapter two, in order to explicate an ethic of toleration. It is worth going back to Locke and the context in which he wrote since toleration is the value according to which modern societies first sought to reconcile deep divisions among their members. The virtue of toleration and the institutional separation of Church and State provided a basis for quieting the religious conflicts that had afflicted Europe in the sixteenth and seventeenth centuries. Following Locke, toleration appeals to reasonableness to overcome a relation of enmity. The basis of political association with the other depends on our common interest in security. Political society is conceived in terms of a voluntary association through which individuals agree to abide by the sovereign so that the life, liberty and property of each can be collectively secured. Toleration seeks to avoid the risk of politics by separating public and private goods. By limiting the legitimate end of politics to the public good of security, the clash of world views is depoliticised so that it no longer constitutes a threat to public order. Yet, I argue, toleration unduly limits reconciliation by grounding social harmony on the exclusion of substantive conceptions of the good from the legitimate ends of politics. For, in doing so, it also precludes the possibility of discovering good reasons for political antagonists to live together in the first place.

In chapter three, I turn to the work of Charles Taylor to consider recognition as an alternative principle in terms of which we might conceive political reconciliation. Taylor is helpful for thinking about political reconciliation due both to his political concerns and the intellectual tradition in which he is situated. Drawing on the experience of Quebec's problematic status in the Canadian federation, he questions the plausibility of the kind of state neutrality between competing conceptions of the good that toleration seeks to establish. For, while the justification of procedures for settling political conflicts may be neutral, in effect they may privilege certain forms of life over others. Following Hegel (and in accordance with "communitarianism" in general), Taylor argues that political society is not properly understood as a voluntary association of contracting individuals. Rather, community emerges out of relations of mutual recognition through which identity is constituted. Rather than predicating social harmony on a benign indifference to the other's form of life, then, Taylor advocates the realisation of community by transforming antagonism into a struggle for 
recognition by which we might come to understand the other in her own terms. Recognition opens the way to a shared horizon of understanding since it proceeds from a hermeneutic engagement between self and other. Yet, I argue, it risks remaining caught in the identarian logic of self and other (that political reconciliation ought to challenge) when it forgets the difference in identity that every act of recognition must exclude.

We have already seen that, since she formulates it against the worldcurtailing crimes of totalitarianism, Arendt's account of the world-disclosing potential of politics provides a promising basis for thinking about reconciliation. In chapter four I show that, for Arendt, the promise and risk of politics arise from our capacity for initiatory action. The promise of action lies in its power to generate new relationships with others and thus the potential that a "we" will emerge from public interaction. Its risk derives from the fact that our freedom to act is given under the condition of nonsovereignty. Because every act falls into an already existing web of conflicting wills and intentions, each actor lacks mastery over the consequences of his actions. Consequently, the boundless and irreversible processes that are initiated through action not only generate community but threaten to undermine it. Yet, following Arendt, the risk of action cannot be overcome by imposing constraints on politics from the outside but must be guarded against by the inherently political activities of promising and forgiving. The world-disclosing potential of politics thus requires mediating between the delimiting and disrupting moments of action. For the promise of politics always also entails its risks. Thus, the "political" emerges as a ceaseless effort of reconciling the boundless potentialities of action with the limits and frailty of the world.

In chapter five, I restate the argument of the first half of the thesis in terms of this ethic of worldliness. I show how an Arendtian perspective is able to illuminate the difficulties that Schmitt's realism, Locke's liberalism and Taylor's communitarianism lead us into. Moreover, I show how it responds to the challenges they pose for thinking about reconciliation and gets us beyond the difficulties. Arendt's ethic of worldliness suggests that political reconciliation requires a fragile holding together of two contending moments of politics, one in which a common world is disclosed between former enemies and the other in which this world is called into question. As 
such, it entails a fractious interaction that seeks to delimit a common horizon that might encompass former enemies while affirming their freedom to unsettle the terms in which this horizon is constituted. Moreover, since an awareness of the risk of politics means that we cannot presuppose community, in order to conceive reconciliation politically we must reverse the order of our thinking. Instead of being initiated by recognition of the moral truth of wrongdoing and proceeding from that toward the restoration of community, political reconciliation begins with the invocation of a "we" that is not yet, in terms of which it seeks to realise a shared understanding of what went before. Thus, while the aspiration for reconciliation conditions the possibility of politics in the present, any ultimate reconciliation in the future is itself a political impossibility.

In the second half of the thesis, I develop this preliminary understanding of political reconciliation in relation to four issues confronting polities divided by past wrongs: constitution of the political association; the possibility of forgiveness in politics; collective responsibility for wrongdoing; and remembrance of a painful past. These four issues provide a context within which to further articulate and elucidate the account of the political developed in the first half of the thesis. The manner in which I proceed thus mirrors the account of political reconciliation I present. Just as I argue that faith in reconciliation conditions the possibility of politics even while we must invoke politics to resist the logic of reconciliation, so I not only derive a theory of reconciliation from the Arendtian account of the political presented in chapter four but seek to further understand the political in relation to the politics of reconciliation as discussed in chapters six to nine.

Political reconciliation is initiated, I argue in chapter six, with the constitution of a space for politics. The meaning of constitution in this context is threefold: in its political sense, it refers to the constituting act by which a space for politics is established; in its legal sense, it refers to the constitutive law that delimits this space; and in its ethical sense, it refers to the "we", the plural subject of law and politics, that paradoxically must both constitute and be constituted in the founding act. In this context, political constitution entails both beginning and promising. By interpreting the present as a founding moment or point of origin, constitution imports an awareness of the frailty and contingency of the "we" it seeks to realise. 
Promising "never again", on the other hand, conditions the possibility of community in the future by establishing shared expectations. In its political sense, then, constitution invokes the "we" of community as an underdetermined potentiality, which enables a reconciliatory politics in the present. Constitutional law, by contrast, must re-present the identity of the people as already existing (and so constituting) in order to establish it own legitimacy. Law tends, in this way, to undercut political reconciliation by over-determining the terms in which it can be enacted. Consequently, we cannot entrust the task of sustaining reconciliation to a legal constitution but must invoke the freedom exemplified in the act of constitution to sustain a reconciliatory politics in the future. The legal constitution of South Africa and the movement for a treaty in Australia are discussed in this context.

If constitution establishes a space for a reconciliatory politics, I argue in chapter seven, this is sustained by a willingness to forgive. While it might not be possible to forgive as an act of will, it is possible to seek grounds for forgiveness. Against necessity (as advocated by realists) and reason (as advocated by liberals), I follow Arendt in arguing that political grounds for forgiveness are the frailty of the world and the natality of the other. In forgiving for the sake of a world we share in common we seek to bring to an end the story that implicates the other in an original transgression. By grounding forgiveness on the other's capacity for initiatory action, we suspend our judgment of the other as our enemy in the present so that she might reveal herself as friend by acting anew. Forgiveness mitigates against the irreversibility of action by refusing to allow the past to determine the possibilities of the present. I discuss the possibility of forgiveness among ordinary citizens in a society divided by past wrongs in relation to the provision of amnesty to perpetrators of human rights violations in South Africa.

In chapter eight, I examine the extent to which ordinary citizens are politically responsible for wrongs perpetrated in their name. By examining the debate between Arendt and her mentor Karl Jaspers concerning the question of German guilt, I show that it is proper to hold ordinary citizens accountable for wrongs perpetrated by their state by virtue of their membership in a political association. Unlike personal responsibility, however, this political responsibility does not entail blame. However, 
assuming political responsibility requires more than just accounting for the past, as if a final settlement could ever be reached. Rather, care for the fragile world that is threatened by the legacy of past wrongs requires a responsiveness to the other, a willingness to live through the consequences of the past in the present. In contrast to a sense of responsibility based on shame, which seeks to redeem an identity tainted by past wrongs, such political responsibility does not so much look to the wronged for forgiveness but invites them to join us in the risky business of realising an identity in common. The question of intergenerational guilt for past wrongs is considered in relation to the debate over responsibility for wrongs perpetrated against indigenous peoples by the settler society in Australia.

Finally, in chapter nine, I discuss the politics of remembrance in a society divided by past wrongs. Following Arendt, I argue that a reconciliatory politics requires respect for factual truth, of that which is simply because it was not otherwise. For, although the world-disclosing potential of politics is predicated on the fact that the world appears differently to each of us, it is only to the extent that we are aware of perceiving the same object in common that this world might appear more common to us. Yet, it is only by being selected and ordered within a story that facts are meaningful. I discuss and problematise Arendt's account of the redemptive power of narrative in relation to the unspeakable truths associated with trauma. Furthermore, I examine Arendt's and Walter Benjamin's philosophies of history: their shared rejection of success as a criterion for historical significance and their different accounts of the importance of remembering the deeds of the defeated. I argue that just as reconciliation seeks to realise a community that is always "not yet", so the task of remembrance remains always unfinished because new aspects of old injustices will be revealed to the backward glance of future generations. The difficulties of remembrance and historical understanding are discussed in relation to the work of truth commissions. 


\section{Reconciliation and Politics}

In an important sense, reconciliation is at odds with politics. Whereas reconciliation tends towards closure, harmony, consensus and union, politics tends towards openness, agonism, conflict and plurality. Nevertheless, reconciliation has become a central term in the political discourse of many divided societies. In this context, a shared commitment to reconciliation enables politics between citizens divided by the violence of the past. Yet, insofar as unity is presupposed as its ultimate end, the logic of reconciliation inclines towards a final settlement that would bring this politics to a close. If we are to understand reconciliation as a political concept, then, we must consider not only how politics might be conciliatory but how reconciliation might be politicised. Consequently, the key argument I will advance in this thesis is this: while the aspiration to reconcile is an enabling condition of politics, politics must be invoked to resist the moment of closure that reconciliation might otherwise tend towards.

Following from this, I will argue that, to understand political reconciliation, we need to reverse the order of our moral thinking. In moral terms, reconciliation refers to the restoration of a wrongdoer to community. By violating the shared norms that bind the moral community, a wrongdoer alienates himself from his co-members. The wrongdoer's return to community is initiated by his acknowledgement of the truth of his wrongdoing and is completed with his forgiveness by those he has wronged. If we are to conceive reconciliation politically, however, we cannot presuppose community but must recognise it as the contingent outcome of interaction. Consequently, political reconciliation begins (rather than ends) with the invocation of a "we." Faith in the possibility of community enables a collective reckoning with the past in terms of which former enemies might eventually arrive at a shared understanding of what went before. 
I begin to make a case for these claims in this chapter by examining the potentially contradictory logics of reconciliation and politics. In 1.1, I consider the legacy of grave state wrongs that political reconciliation must address. In such circumstances, I argue in 1.2, it is not adequate to conceive reconciliation in terms of restoration because this makes an unwarranted presumption of community. By contrast, I suggest in 1.3, a political conception of reconciliation would be conditioned by an awareness of the risk of politics that Carl Schmitt draws our attention to: the ever-present possibility of the friend-enemy relation. In 1.4, I show how this guiding distinction brings to light the politics of reconciliation, which tends to be obscured by the religious, therapeutic and economic discourses in which it is often represented. Yet when the distinction between friend and enemy becomes an organising principle of politics it seems to preclude the possibility of reconciliation altogether. Following from this, I suggest that the problem political reconciliation must address is not how to overcome a relation of alienation between co-members of a moral community but, rather, how to transform a relation of enmity into one of civic friendship.

\subsection{The legacy of grave state wrongs}

If the crowning political achievement of modernity is the development of constitutional democracy, this also has its dark side. The innovation of the eighteenth century revolutions was to combine the liberties of the moderns with those of the ancients by conjoining rule by the demos with the rule of law. On the one hand, the legitimacy of the state was established by divesting sovereignty from the monarch and investing it in "the people." On the other hand, it was understood to depend on the state's role in securing the private freedoms of individuals as proclaimed in the Rights of Man (see Tully 2002: 205-211). Yet, despite this achievement in principle, modern states have, in fact, been responsible for the most pervasive and systematic destruction of human life in history. State-organised killings are often described as acts of barbarism or madness, which suggests that they are an aberration of the fragile achievement of civilisation. Yet on closer examination the ethnic and political cleansing of certain categories of people 
from within a territory under the control of a state appears to be a distinctly 'modern tradition' (Mann 1999: 18).

The modernity of genocide is apparent not only in the technocratic means employed to bring it about but the end for which it is perpetrated. As Zygmunt Bauman (2000: 91) argues, traditional motives for mass extermination range from 'cold-blooded calculation of competitive gain' ("there is no room for both of us") to 'disinterested hatred or heterophobia' ("the only good Indian is a dead one"). With modern genocide, by contrast, elimination of the other is not an end in itself but a means to realising a rational design for society. It is part of a plan to remake the world in the image of an ideal. Mass extermination is undertaken in order to bring about a 'harmonious world, conflict-free, docile in the hands of [its] rulers, orderly, controlled' (Bauman 2000: 93). Bauman, thus, shows modern genocide to be consistent with the 'civilising process' itself and, in particular, with the instrumental rationality in terms of which modern society is organised. In this context, law - which is supposed to restrain violence - becomes a means to regulate its systematic deployment.

Moreover, as Michael Mann (1999) suggests, genocide may be regarded as the 'dark side of democracy' since modern regimes typically justify their murderous projects in the name of "the people." Since every act of inclusion is predicated on one of exclusion, the invocation of the idea of "the people" often functions not only to legitimate the state but to generate a sense of an alien other that threatens the integrity of the people from within. Because the claim to sovereignty is not only a claim to self-determination but a claim over territory, this may lead to these others being forcibly removed from the territory of the people (Mann 1999: 21). Various types and degrees of "cleansing" have been applied by states in order to protect the sovereignty of a people from an alien form of life within the body politic. These have included cultural assimilation, biological assimilation, coerced emigration, murderous cleansing and, ultimately, genocide (Mann 1999: 22).

Both the rationalisation of mass murder as a means to a better social order and the undertaking of this act to secure the sovereignty of the people are motivated by a profoundly anti-political mentality (as we will see in 4.1). For they are driven by a resentment of the plurality of the human world, the 
unpredictability of action and the always unfinished character of community. Consequently, the memory of such offences undermines the possibility of politics in the present between those implicated in wrongdoing and those targeted for persecution. The knowledge that what has been could be again emasculates the conditions that enable social trust since it establishes a selfperpetuating legacy of hatred, fear, guilt and resentment.

Since the end of the Cold War, many societies have been struggling to arrest and overcome the legacy of grave state wrongs. Attempts to reckon with a painful past are often associated with a transition to democracy during which a range of official responses are available to a new regime. These include amnesty and criminal trials, reparation and restitution, removal of collaborators from public office, official investigations into the causes and consequences of state wrongs and constitution making (see Minnow 1998; Teitel 2000). Such measures are usually referred to as forms of transitional justice since they are associated with a period of rapid political change during which the demand for retributive justice must be balanced against the imperative to consolidate a democratic regime (see Huntington 1991: 208-279). Efforts to reckon with state wrongs, though, have not been confined to new democracies, which must tread lightly in their justiceseeking measures for fear of a military coup or return to civil war. In many well-established democracies, the memory of offence continues to be a source of grievance for a section of the population and presents a legitimation crisis for the state.

Yet legal remedies alone are insufficient to address the legacy of grave state wrongs. For, important as they are, the goals of "restoring the rule of law" and "promoting a culture of respect for human rights" presume that state wrongs represent a temporary aberration of the moral-political order. Consequently, they tend to overlook the law's historical role in sanctioning state violence. Moreover, such legal strategies do not allow for the possibility that the memory of offence might foreclose the possibility of political association in the present. This risk is real because those "ordinary citizens" who were neither immediate perpetrators nor victims are invariably implicated in the modes of oppression or conflict that underpin political violence. Given the persistence of hard feelings between citizens, focusing on institutional reform and legal remedies might, at best, facilitate a more 
fundamental reckoning with the past. For, in such circumstances, ordinary citizens need to find good grounds to live together in the first place if they are to affirm the legitimacy of shared institutions. This fundamental reckoning is inherently political because it centres on the possibility of invoking a "we" that might meaningfully include both the perpetrators and the survivors - the oppressors and the oppressed - of the former regime.

In this context, the concept of reconciliation has recently emerged within the political discourse of divided societies such as South Africa, Australia, and Chile. In these countries, reconciliation has been promoted by the state as a way of dealing with the legacy of grave wrongs perpetrated by a former regime. As Priscilla Hayner (2002: 161) observes, reconciliation 'implies building or rebuilding relationships today that are not haunted by the conflicts and hatreds of yesterday.' In the reconciled polity, she argues, the wrongs of the past could be discussed openly and without bitterness in public. Relationships between former antagonists would be based on responding to present challenges rather than identifying each other in relation to past events. Moreover, there would be some common agreement on fundamental historical facts concerning what wrongs were perpetrated (see also Govier \& Verwoerd 2002). However, as Hayner acknowledges, it remains unclear, beyond this minimal definition, what political reconciliation should amount to and how it should be achieved. Consequently, the meaning of reconciliation tends to be vigorously contested among citizens divided by past wrongs.

According to W.B. Gallie (1969: 123), an 'essentially contested concept' is one whose proper use 'inevitably involves endless disputes about [its] proper [use] on the part of [its] users.' 'Reconciliation' is clearly such a concept. ${ }^{1}$ Actors may disagree over what form reconciliation should take or how it should be realised. However, even the most conservative supporter and the most radical opponent of the old regime are likely to agree that reconciliation is a desirable social good in the changed political circumstances in which they find themselves. Reconciliation is an internally

\footnotetext{
${ }^{1}$ Following Gallie (1969: 123), an essentially contested concept is appraisive (since it signifies some kind of valued achievement), of an internally complex character (since it refers to a nest of practices) and ambiguous (such that the rules of its proper application are open to interpretation by different parties according to particular circumstances). See also Connolly (1993: 10f.).
} 
complex concept since it refers to a cluster of practices that include (among other things) repenting, restoring, punishing, apologising, repairing, forgiving, redeeming, forgetting, remembering, promising and understanding. Moreover, it is a concept broadly open to interpretation so that actors are likely to differ significantly in their understanding of what true reconciliation would entail. In South Africa, for instance, reconciliation was interpreted differently by various actors in terms of: a non-racial ideology that promotes unity in the form of the 'rainbow nation'; an intercommunal understanding that would preserve the distinct identities of separate cultures; a religious ideology that demands repentance from wrongdoers; a human rights approach that calls for restoring the rule of law in order to prevent future abuses; and community building that would restore social trust in divided townships (Hamber \& van der Merwe 1998). ${ }^{2}$

This essential contestability shows reconciliation to be a fundamentally political concept. As Brandon Hamber \& Hugo van der Merwe (1998) discuss, although the various interpretations of reconciliation they identify sometimes co-existed 'quite comfortably' within political institutions and discourses in South Africa, they are, in various ways, incompatible. Consequently, the different meanings assigned to reconciliation often emerged at the 'core of the conflict between different groups.' This conceptual contestability should be affirmed because, as I will show, it creates a 'space for political interaction' (Connolly 1993: 6). As William Connolly (1993: 6) argues, politics typically entails an 'ambiguous and relatively open-ended interaction of persons and groups who share a range of concepts but share them imperfectly and incompletely.' By accommodating multiple meanings, reconciliation provides a common vocabulary within which citizens may contest the terms and possibility of their political association. Political reconciliation depends on this conceptual contestability because it points to an ambiguity that counters a certain antipolitical view of reconciliation, which forecloses political opportunity by privileging consensus as a regulative ideal.

\footnotetext{
${ }^{2}$ Competing conceptions of reconciliation similarly emerged in Australia, most notably between Prime Minister Howard's promotion of 'practical' reconciliation (based on universal principles of social justice) against a more historically informed, reparative approach supported by his predecessor, Paul Keating (see Grattan 2000).
} 


\subsection{Political inadequacy of restorative reconciliation}

The essential contestability that is inherent to any political conception of reconciliation tends to be occluded when reconciliation is construed in terms of restoration. According to advocates of restorative justice, such as Christopher Bennett (2002), reconciliation is central to the way we make sense of moral experience. Wrongdoing is understood, in this context, in relation to the ideal of union - that being joined together with others completes us (Morris 1976: 96). In transgressing a norm that mediates relations between members of a community, an individual not only causes injury to the person wronged but demonstrates a lack of commitment to the values of the community to which he belongs. Through transgression, then, the wrongdoer alienates himself from a moral community (MacIntrye 1985: 151f.; Morris 1976: 96). The retributive sentiments of resentment on the part of the injured party and indignation on the part of other members of the community express blame and communicate withdrawal of the usual solidarity extended toward a co-member of the community (Bennett 2002: 149-153).

Alienation brings the wrongdoer to recognise his transgression and, hence, to share the community's moral disapproval of his act. In coming to recognise how he has damaged a valued relationship, he accepts blame and so feels guilty. The suffering associated with guilt arises both from recognition of the hurt inflicted on another for whom one cares and from the feeling of separation from others (Morris 1976: 99-100). The experience of guilt thus leads to repentance; acknowledgement that one has failed to live one's life according to the values one shares with others and reaffirmation of one's commitment to those values. In repenting, the wrongdoer distances himself from his act - he repudiates the wrong as incommensurate with his identity as a member of the moral community - and so initiates 'a rite of passage back to union' (Morris 1976: 96). The end of atonement, in other words, is an 'at-one-ment' with others (Perrin \& Veitch 1998: 226; Morris 1976: 100).

The way to reconciliation involves attending to the negative consequences of one's actions through apology, reparation and penance. By acknowledging responsibility, expressing sorrow and regret and reaffirming 
his commitment to the values of the community, 'the offender simultaneously recalls and is re-called to that which binds' (Tavuchis 1991: 8). Through reparation one seeks to set things right, to compensate those wronged for harm to person and property. Typically, though, some further extraordinary sacrifice or effort is required. Penance involves a willingness to suffer for what one has done and to go beyond the call of duty to demonstrate one's commitment to a relationship. Apology, reparation and penance are, in this way, all oriented to the 'restoration of relationships damaged by past conflict' (Morris 1976: 97). This rite of passage back to union is completed by forgiveness; the relinquishment of resentment. Resentment (justly) holds the wrongdoer at arms length and so constitutes an obstacle to restoration. According to Jeffrie Murphy (1988: 19), an offer of forgiveness should be conditional on satisfaction that the wrongdoer no longer holds us in contempt, that he has accepted responsibility for his actions and has reaffirmed his commitment to communal norms. Forgiveness then amounts to an acknowledgement of reconciliation - the restoration of a damaged relationship. ${ }^{3}$

This restorative conception of reconciliation provides a persuasive account of the moral psychology involved in the way we commonly respond to and seek to ameliorate wrongdoing. Yet, it is politically inadequate for at least three reasons. First, it suggests the prior existence of harmonious or friendly relations between groups whereas in the case of state wrongs there is often 'nothing to go back to' (Krog 1998: 109). Indeed, the relationship between groups often originates in a wrong such as colonisation or slavery. State wrongs are typically perpetrated against categories of people who are not recognised as members of the moral-political community. Alternatively, violence is legitimated in the name of community; oppression of one part is justified for the sake of the whole. Yet the restorative conception of reconciliation does not to distinguish between wrongs perpetrated within a

\footnotetext{
${ }^{3}$ While personal forgiveness restores the relationship between offender and victim, it does not necessarily preclude punishment. For, although the victim has exclusive authority over whether to forgive an injury, the question of punishment is a matter for a third party to decide - an authorised representative of the community whose norm has been violated.
} 
community of moral equals and wrongs that are legitimated by a political regime. ${ }^{4}$

Following from this, the moral conception of reconciliation does not recognise that, within a polity divided by past wrongs, reconciliation would not involve the restoration of the moral-political order but rather would require a fundamental reconfiguring of that order. The notion of restoration suggests that a previous order has been violated by wrongdoing and that reconciliation requires the reaffirmation of those norms that this wrong called into question. Yet it is in the nature of state wrongs that they do not transgress a political order but are intended to uphold one. State violence is justified for the security of the political association. Rather than restoration, then, what seems to be required is revolution; a radical break with the past and the initiation of an entirely new order.

Third, the restorative conception of reconciliation does not distinguish between the political and the moral. It presupposes that the norms of the moral community are publicly known and bind all who belong. However, the plurality that attends public life means that there is likely to be conflict over the applicability of norms according to which wrongful acts should be judged. There may be agreement on brute facts: that a particular individual killed several people, for example. However, while members of one group may understand him to be a freedom fighter, members of another might consider him a terrorist. In such instances, conflict is of a second-order; it concerns not the proper application of a norm but the validity of the norm itself.

An advocate of the restorative ideal might respond to these criticisms by pointing out that the moral relevance of the ideal of reconciliation does not depend on the coincidence of moral and political communities. Thus, although an actually existing political community failed to recognise certain categories of people as members of the moral community, we should insist

\footnotetext{
${ }^{4}$ In fact, Morris (1976: 96) does draw such a distinction, but in doing so seems to preclude the applicability of restorative reconciliation in the contexts with which we are concerned. He writes: 'Wrongdoing...gives rise to guilt and separation from those with whom one was joined. Those who are not viewed as within this union may be viewed as dangerous, but their conduct is not seen as wrongdoing. They may be controlled; they may be reacted to as we sometimes react to wild animals, but they are outside the world of wrongdoing with its implications of separation and union.'
} 
that it was wrong to do so. By excluding these others, the members of a political community failed to recognise a pre-existing structure of mutual obligations and responsibilities. Similarly, it would follow from this that we are right to presuppose a continuous moral order despite the messy reality of politics. Just as the bounds of the moral community remain the same despite those of an actually existing political community, so the moral order continues despite the temporary aberration of an immoral political order. ${ }^{5}$

However, while it may well be true that we have moral obligations towards others that are universal and independent of actually existing political relations, it would be a political mistake to take for granted a shared set of moral norms according to which political relations should (or could) be ordered. For moral norms are politically relevant only to the extent that they are attested to and contested - upheld or rejected - by members of a political association. Just as we should resist the conclusion that what is at stake in morality is, in the end, a matter of politics, we should not assume that political concerns are ultimately reducible to the demands of morality. As we will see, politics is characterised by a clash of world-views over relevant moral norms and the risk of enmity this gives rise to. Consequently, a political conception of reconciliation cannot take for granted a moral community that must be restored but, rather, must recognise the community it seeks to realise as a contingent, historical possibility.

\subsection{The risk of politics}

According to Carl Schmitt, politics is conditioned by the ever present possibility of the friend-enemy relation. As such, politics is inherently conflictual and ultimately turns around the terms of association and dissociation among people. Schmitt's concept of the political provides a challenge for thinking about reconciliation because he draws attention to the risk that a conflict about the significance of past wrongs may turn out to be irreconcilable. A politically adequate conception of reconciliation, then, would be predicated on an awareness of this risk.

\footnotetext{
${ }^{5}$ I am indebted to Christopher Bennett (personal communication, August 2002) for offering a defence along these lines.
} 
Schmitt distinguishes 'the political' from other modes of action and judgement (moral, aesthetic, economic) not in terms of its substantial concerns but its guiding distinction. Whereas the moral concerns the distinction between good and evil, the economic the distinction between profitable and unprofitable and the aesthetic that between beautiful and ugly, the political significance of action and judgement can always be traced to the distinction between friend and enemy (CP: 26). The political is 'autonomous' from other modes of human interaction, then, not because it describes a separate domain of intercourse or mode of human relation but a peculiar criterion of judgement. As the guiding distinction of politics, the friendenemy relation cannot be reduced to moral, aesthetic or economic criteria. The political enemy is not necessarily ugly, evil or our competitor, although he might turn out to be (CP: 27, 36). But our enemy is by definition 'other' 'something existentially different and alien' (CP: 27). As such, he constitutes an existential threat to our own form of life. To identify an enemy is thus to recognise the possibility of war: that we might have to fight in order to preserve our own form of existence.

For Schmitt, politics ultimately concerns the terms of association and dissociation among people (CP: 38). Fear of harm or domination by others is what leads people into political association. Since the state is a sovereign entity that commands obedience in exchange for protection, Schmitt insists (against liberal pluralism) that the state cannot be one association among a plurality of others to which its members may be loyal (CP: 52). Rather, the political association is the decisive association because it commands an allegiance for which its members must be prepared to stake their lives (CP: 46). The mark of sovereignty is the capacity to decide on the friend-enemy relation ( $\mathrm{CP}: 30,35)$. In normal times of public security and order, the sovereignty of the political association is not apparent; public life appears to be governed by the normative order of law. However, a general norm can never encompass the exception, which by definition 'cannot be codified' in an existing legal order (PT: 6). Consequently, the arrival of the exception and the need to suspend law during the political emergency reveals the fallacy of the 'rule of law' (PT: 9). The authority of the sovereign to decide the exception demonstrates that every legal order ultimately 'rests on a decision and not on a norm' (PT: 9-10). 
The friend-enemy relation emerges, then, in the confrontation between groups. For the conviction, by members of various groups, that they 'possess the truth, the good, and the just' brings about the 'worst enmities' (CP: 65). The risk of war thus defines the circumstances within which politics is enacted (CP: 19). Yet the political 'does not reside in the battle itself...but in the mode of behaviour which is determined by this possibility' (CP: 38). As such, politics always entails antagonism - the clash between different forms of life - and every antagonism becomes more political the closer it approaches the extreme case of the friend-enemy grouping. This conflictual nature of politics is evident in the polemical aspect of all political discourse the essential contestability of political concepts. For Schmitt, the political meaning of a concept, image or term can only be comprehended by considering who is 'affected, combated, refuted or negated' by it (CP: 31). Indeed, whether something is political or not is itself a political question. To claim that one is adopting a non-political stance, for instance, is typically to claim the higher moral ground - to present one's opinion as incontestable moral truth. Conversely, to denounce an adversary's point of view as political is to refute it by suggesting that it is biased and self-interested rather than impartial.

Schmitt thus understands the ever-present possibility of enmity to be an inescapable feature of human association (CP: 79). In drawing attention to the guiding distinction of the friend-enemy relation his intention is to bring the political to recognition against the liberal tendency to obscure it. Against a politics of consensus, Schmitt presents a politics of dissensus. In contrast to a certain liberal understanding of politics as the historical unfolding and pacific expansion of a universal morality' he presents a particularist account of politics that, while allowing that individual conflicts might be resolved, presupposes that 'antagonism as a structure and reservoir of possible future conflict is never destroyed' (Rasch 2000: 10). The risk of politics cannot be eliminated but only elided by pursuing politics through the discursive modes of law, economics or morality.

Yet, as Leo Strauss (1995: 111-113) points out, Schmitt not only recognises the political but affirms it. He attacks the liberal effort to subordinate politics to ethics and economics because the seriousness of life is at stake. Liberalism substitutes procedure for struggle, economic competition 
and interminable discussion for political antagonism (CP: 28, 71). But the liberal ideal of a depoliticised world could be realised only if human beings ceased asking ultimate questions. A world without politics might be interesting and entertaining but there would be no beliefs or values for which people were prepared to stake their lives (CP: 35). For Schmitt, then, the 'high points' of politics occur in the moment in which the other is recognised as enemy because it is in this extreme situation that the significance of our life in common - what "we" stand for - is affirmed (CP: 67).

With his concept of the political, then, Schmitt means to affirm plurality. The political world, he insists, is a 'pluriverse not a universe' (CP: 53). Yet this pluralism does not subsist between individuals or the associations of civil society but between states. Schmitt rejects liberalism because it places pluralism in the service of a universal ideal. But this ideal of humanity is an unpolitical concept because it recognises no outside (CP: 54). In a 'world among good people' in which the humanitarian ideal had been realised 'only peace, security, and harmony [would] prevail' (CP: 65). Yet when politics is enacted against the horizon of humanity, antagonism is not pacified but outlawed. By staking an absolute and incontestable ideal as its standard, liberal pluralism leaves no representational space - no ambiguity in terms of which the regime it would institute could be contested. The ideal of humanity is absolute and incontestable because it incorporates all conflict within a single constituency in terms of which it could be resolved (CP: 5354). Schmitt's concern is, thus, with the difficulty of staging opposition in a liberal universe that does not recognise its own outside (Rasch 2000: 14). He turns to the system of states to protect plurality among humankind because in this system there is no sovereign power to overawe all. Consequently, it guarantees a value-neutral pluralism in which there is no higher moral ground to claim. On this account, then, politics is not the means by which a universally acknowledged good is actualised. Instead, it is an activity through which disputes are negotiated and limited in the absence of any such good (Rasch 2000: 11).

Schmitt rightly emphasises that politics is ultimately concerned with the creation of a "we" and that the enabling condition of politics is contestability, the absence of a universal standpoint in terms of which 
conflict could potentially be resolved once and for all. Consequently, as Michael Dillon (1999: 161) observes, justice is always related to an allied regime of politics, 'the frame within which it is staged, legislated, and executed.' Following Schmitt, then, a political conception of reconciliation must attend to the risk of politics. It cannot presuppose a community that must be restored but must recognise community as a contingent outcome of political interaction.

\subsection{The politics of reconciliation}

Schmitt's insistence on the friend-enemy relation as the guiding distinction of politics is important because it directs our attention to what the restorative conception of reconciliation elides. By taking harmony as a regulative ideal in terms of which contemporary divisions should be understood, restorative reconciliation outlaws conflict that might call into question the basis of this unity. Political grievances and disputes are disciplined by representing them as communal when they might otherwise have challenged the legitimacy of community. Thus, just as liberalism obscures the politics of its own exclusions through non-political modes of discourse, so reconciliation is depoliticised when represented in theological, therapeutic and economic discourses. As we shall see, the metaphors of redemption, healing and settlement, with which reconciliation is often associated, all serve to elide the risk of politics by presupposing a single constituency (see Veitch 1999: 150151). However, the guiding distinction of the friend-enemy relation brings the politics of reconciliation back into view.

Reconciliation is central to the Christian religion since it provides the narrative link between the Hebrew scriptures and the New Testament. According to Paul, just 'as by the offence of one judgement came upon all men' so 'by the righteousness of one the free gift came upon all men unto justification of life' (Romans 5: 18). Adam's original sin brought about alienation both between humanity and God and among humankind (Genesis 3: 15). The sacrifice of Christ restores humanity to God through the gift of Grace. For God was in Christ 'reconciling the world unto himself' (Corinthians 5: 19). God made Christ 'to be sin for us, who knew no sin, that we might be made the righteousness of God in him' (Corinthians 5: 21). 
Though sinners in the flesh, we are redeemed by the sacrifice of Christ when we accept the gift of Grace (Colossians 1: 21-22). Moreover, Grace makes way for peace between worldly enemies. Through Christ, those who were 'strangers and foreigners' are reconciled as 'fellow citizens with the saints, and of the household of God' (Ephesians 2: 19). Those who were 'far off' are 'made nigh by the blood of Christ' (Ephesians 2: 11f.).

The reconciliation of a divided society is often premised on the need to redeem a painful past for the sake of a common future. There is a sense that the sacrifice of the victims of state terror should not have been in vain but might have been for the good of a better society (see Veitch 1999; Humphrey 2000). This religious discourse was prominent, for instance, in the workings of the Truth and Reconciliation Commission (TRC) in South Africa (see Graybill 1998). Ritualised public hearings began and ended with prayer and were presided over by Desmond Tutu dressed in his purple Archbishop's cassock. There would be a solemn atmosphere, with candle lighting 'to commemorate those who had died in the struggle' (Tutu 1999: 81). The significance of death by political violence was interpreted through the imagery of redemptive sacrifice. Moreover, central to Tutu's (1999: 31) understanding of reconciliation was the notion that social harmony is the greatest good and anything that undermines this must be steadfastly avoided. Tutu writes of a divine movement in the world to 'reverse the awful centrifugal force of alienation, brokenness, division, hostility, and disharmony'. God has set in motion a movement 'toward unity, harmony, goodness, peace' and the removal of all barriers. In this vision of an ultimate reconciliation, none are outsiders since 'all belong' (Tutu 1999: 265).

Reconciliation is also often represented in terms of the metaphor of 'healing.... traumatised, divided, wounded, polarised people' (Tutu in Ignatieff 1996: 110). In imagery that recalls the myth of Oedipus, the body politic is understood to have been infected by internecine violence or a corrupt regime. In this context, the image of the wounded body becomes a template of collective memory, 'both a map and moral charter' (ScheperHughes 1998: 125). Social healing is associated with restoring a moral order that has been violated (e.g. Zalaqeuett 1995: 46-47; Milliken 2000: 125). Revelation of the truth of past wrongs is counselled on the basis that 'what is not dealt with poisons the body politic' (Asmal 1995: 29). 
In neo-Freudian therapeutic discourse, healing from trauma depends on recalling, narrating and incorporating a traumatic experience that remains a silenced and unresolved memory (e.g. Herman 1992; see Prager 2001b). As a single shattering blow, a traumatic event destroys the victim's fundamental assumptions about the safety of the world, positive value of the self and meaningful order of experience. The life experience of the individual becomes 'dominated by a discontinuity in life so dramatic and profound that it overwhelms all other experience'. Trauma 'expresses itself as time standing still', a continual re-enactment of the past in the present since insecurity and fear overwhelm all trust and hope (Prager 2001a). Similarly, widespread state violence is often understood to result in collective trauma. The traumatic wounds inflicted on individuals can combine to manifest a pathological mood within a community that is more than the sum of private wounds (Prager 2001b). In this context, social healing is understood to depend on incorporating the traumatic event into collective memory. Through public narration and acknowledgement of the stories of survivors it is hoped that a catharsis might be brought about (e.g. Asmal 1995: 30). ${ }^{6}$ The memory that rebounds in the present as an inexplicable rupture is integrated into a narrative whole. Uncovering the secret of trauma is, in this way, supposed to bring social healing by 're-establishing the autonomy of time' - allowing the past to take its place as past (Prager 2001a).

A third metaphor in terms of which reconciliation is often represented is that of "settling accounts." Kader Asmal and others (1997: 47), for instance, suggest that reconciliation should be understood as 'a closing of the ledger book of the past...like the accountant's job of reconciling conflicting claims' (see also Borneman 1997; Digeser 1998: 706). As Paul Ricoeur (2000: 14) observes, the metaphor of settling accounts suggests 'a kind of moral bookkeeping of merits and demerits, as in a double entry ledger: receipts and expenses, credits and debits'. To reconcile an account is to calculate, to make sure everything adds up correctly on either side of the ledger to produce the correct balance.

\footnotetext{
${ }^{6}$ On an individual level, the dignity of survivors is supposed to be restored through public acknowledgement of their suffering. The individual is brought back from stigmatised isolation into social belonging through the public sharing of pain. Collectively, healing is supposed to occur through addressing the legacy of violence. Through public story-telling and mourning a sense of closure is achieved.
} 
As such, the metaphor of settling accounts implies both the idea of being held to account (to repay a debt one has incurred) and of being called to account (to report, recount, set the record straight). In terms of this moral calculus, restoring the rule of law is understood to depend on perpetrators being held to account in a court of law. When amnesty is granted to perpetrators this is sometimes presented as forgiving their debt to society in order to turn a new page in the nation's history. Ordinary citizens are called to account for their complicity with the regime and expected to acknowledge a debt to the victims. There is a need to settle accounts through the payment of reparations. Moreover, there is a call to set the record straight, to give a full and proper account of the wrongs perpetrated by the previous regime.

The guiding distinction of the friend-enemy relation reveals the depoliticisation of reconciliation when represented in these religious, therapeutic and economic modes of discourse. For, in every case, plurality is placed in the service of a higher unity: a nation to be redeemed, a society to be healed, a truth to be settled. In these terms, the reconcilability of political conflict is taken for granted. By promoting social harmony as an unconditional common good, the terms within which this unity is constituted are presented as unambiguous. Consequently, no representational space is left in which the terms of reconciliation itself might be contested.

For instance, as Claire Moon (2000) discusses, Tutu's invocation of a Prelapsarian human condition in his appeal for reconciliation in South Africa 'subjects the nation to a seamless continuity of representation.' This metaphor elides the risk of politics by 'constituting the nation as a timeless and originary form of community' (see also Chandra-Shekeran 1998). As Scott Veitch (1999) argues, when the stakes of reconciliation are tied to the redemption of the nation in this way, the establishment of a collective

\footnotetext{
${ }^{7}$ Moon suggests that religious tropes and narratives may be especially resistant to change, and so tend to foreclose politics, due to their 'strict codifications and textual groundings'. Yet, she suggests, a metaphor may also open up the possibility of politics since it 'gestures beyond that which it seeks to name, and beyond the seemingly immutable givens of an existing order'. Indeed, the richness of reconciliation as a political concept is due, in particular, to its religious significance since its over-determination with meaning makes it both resonant for many different actors and imbues it with an ambiguity that makes it contestable. Thus, I do not want to suggest that the concept of reconciliation is too religious; only that it is in danger of being not political enough.
} 
memory on which community is supposed to depend requires a selective forgetting of that which might call into question the commonness of the past. Since political antagonism inevitably disrupts social harmony, a dissenting politics that challenges the terms in which a consensus would be realised, must, it seems, 'be avoided like the plague' (Tutu 1999: 31).

The organic metaphor of a body politic in need of healing similarly tends to naturalise the historical community by representing continuing antagonisms as jeopardising the health of community. Ricardo Trumper (1999: 16), for instance, discusses how the Pinochet regime represented the nation of Chile as a sick body that needed shock treatment to eliminate the Marxist cancer. Following the transition to democracy, this imagery was retained but now the 'body needed time and soothing medicine, a noninvasive cure, to heal. The politicians argued that "we" needed to (re)conciliate, allow the country's wounds to close' (Trumper 1999: 24). Yet, the unequal social relations that the Pinochet regime seized power to defend were left unchallenged because they were naturalised and depoliticised in terms of an idealised image of a healthy political body, 'at peace with its self, with no contradictions' (Trumper 1999: 24). Similarly, as Michael Humphrey (2000: 24) discusses, in South Africa the fundamental and sometimes ambiguous social distinctions that shaped individuals' experience of political violence were often covered over through the symbolic re-presentation and appropriation of survivors' testimonies in the name of healing divisions within the body politic. The focus on healing through sharing the pain of individuals often provided a ready escape from the difficult political questions arising from the context of continuing antagonism between social groups.

Likewise, the representation of reconciliation in economic terms renders all political claims calculable and, hence, reconcilable. To settle accounts is to establish certainty by resolving any ambiguity in order to protect the debtor from further claims being raised against him. However, this glosses over the fact that state wrongs often inflict on survivors 'a loss that is irrecoverable, incalculable, immemorial' (Perrin \& Veitch 1998: 231). As Colin Perrin and Scott Veitch (1998: 228-229) observe in their discussion of reconciliation in Australia, there is an injustice discernable in the presumption that it is possible to achieve a complete settlement. For this 
forecloses the possibility that a debt may have been incurred that cannot be repaid and so must remain unsettling. Similarly, in his commentary on the politics of reconciliation in Argentina, Mario Di Paolantonio (1997: 454) observes that to claim that 'past injustices have been finally explored, catalogued, and dealt with once and for all...is to "finish off" the past's claims on the present.' Yet it seems that such resolution can only be achieved by reduction; by re-presenting the past in terms of a calculus that necessarily renders conflict reconcilable. In this way, economic discourse elides the risk that it may turn out to be irreconcilable.

We are left, as Scott Veitch (1999: 58) observes, with the 'political concern about reconciliation as recovery, as a covering over that "persisting anxiety" which lies at the core of political possibility.' When represented in terms of redemption, healing and settlement it seems that reconciliation 'merely acts to drive under - but for how long? - conflicts that are at the heart of agonistic politics' (Veitch 1999: 58). The ideal of reconciliation, as we have seen, suggests harmonisation, restoration, redemption, healing. On the other hand, following Schmitt, politics is characterised by interminable conflict, incommensurability, division, uncertainty. To reconcile is to resolve; to settle. To politicise is to open up; to call into question. As Schmitt reminds us, politics turns around the question of who "we" are; the terms of inclusion and exclusion. The aspiration to reconcile becomes unpolitical then, when accompanied by a forgetfulness that the "we" it seeks to realise is not a given but the contingent outcome of interaction. As I have shown, the therapeutic, religious and economic discourses in which reconciliation is often represented are complicit in such forgetting.

Against this tendency, a politically adequate conception of reconciliation would be conditioned by an awareness of the risk of politics; that community is not inevitable and that conflict may turn out to be irreconcilable. From this perspective, the "we" that the restorative conception of reconciliation invokes as its pre-determined end must be reconceived as an horizon of possibility that enables a reconciliatory politics in the present. As we shall see, if the aspiration to reconcile is not to undercut the enablement of a reconciliatory politics in the present, this must be kept in view for being just that: an article of faith that depends upon accepting the risk of politics (and the opportunity it presents) rather than eliding it. 
While acknowledging the risk of politics to which Schmitt draws our attention, however, we may nonetheless resist it as an inevitable outcome of human interaction. For when the friend-enemy relation ceases to be a guiding distinction and becomes instead an organising principle of politics, it leads to a 'false radicalisation' of political life, which Slavoj Zizek (1999: 29) appropriately calls 'ultra-politics'. When politics is overcome by enmity this precludes the kind of symbolic interaction - which I earlier associated with essential contestability - on which a reconciliatory politics depends. If Schmitt's realist concept of the political provides an important challenge, then, it is one that we must answer not only to formulate a more political concept of reconciliation but to develop a more ethical concept of the political.

In particular, we need an account of plurality that subsists between citizens and thus allows for the possibility of politics within the political association. Schmitt affirms the political because he senses that through politics humans confront and struggle with ultimate questions. While he affirms plurality as an enabling condition of politics between sovereign entities, however, it becomes a threat to sovereignty when it arises within the political association. However, by privileging politics between states over that between citizens, Schmitt does not recognise the latter as a site in which shared meanings might be generated. ${ }^{8}$

Following from this, it appears that a more robust account of political friendship will be required than Schmitt can provide if we are to imagine the possibility of reconciliation within a deeply divided society. For Schmitt, the association determined by the friend-enemy relation is always the decisive human grouping. This suggests that one comes to know one's political friends only by knowing one's enemies. However, it seems that the sense of fraternity based on a common enemy is too precarious to sustain community between members of a polity divided by past wrongs, especially when the political emergency recedes.

\footnotetext{
${ }^{8}$ As Rasch (2000: 19 - emphasis in original) argues, 'Schmitt could not see a structure of differentiation carried by a unity that itself was structured by differentiation. This then, becomes, our challenge. If we accept conflict as the basic definition of politics...then it becomes necessary to extend his 'logic' of conflict, to 're-enter' his friend/enemy distinction within the state, without thereby collapsing the grander structure he outlines.'
} 
What I want to take from Schmitt, then, is a sense of the predicament in which a reconciliatory politics must be enacted. In this context, the problem that political reconciliation must address is not how to restore community between alienated co-members. Rather it is, as Chantal Mouffe (1999: 755) suggests, how an antagonism between enemies might be transformed into an agonistic politics between adversaries. As Mouffe (2000: 102) points out, treating the other as an adversary rather than antagonist does not eliminate the risk of politics since our adversary may remain our enemy. However, he becomes a 'legitimate enemy' because we share a commitment to the principle of reconciliation. Yet, because our shared understanding of reconciliation is imperfect and incomplete, the politics that arises between us is likely to be agonistic in the sense that our disagreement may not be resolvable by deliberation and rational discussion.

In the first of half of this thesis, then, I look to three political thinkers John Locke, Charles Taylor and Hannah Arendt - who each suggest a political ethic that might provide a basis in terms of which to formulate a politically adequate conception of reconciliation. Each of these thinkers is concerned, in his or her own context, with how to accommodate plurality within a political association. Moreover, each offers an account of the political that is formulated, to some extent, against the realist tradition in which Schmitt is situated. Consequently, each advocates an ethic that suggests how a relation of enmity might be transformed into one of civic friendship. Locke's ethic of toleration seeks to contain the risk of politics by limiting the terms of political association to providing for the mutual interest former enemies have in security. Taylor's ethic of recognition seeks to transform the risk of politics into an opportunity to realise community by recasting a relation of enmity into a reciprocal dialogue oriented toward a shared understanding. Arendt's ethic of worldliness takes this risk as the enabling condition of an agonistic politics in terms of which the commonness of the world that lies between former enemies might be disclosed. 


\section{Toleration}

I have just argued that a politically adequate conception of reconciliation must be conditioned by an awareness of the risk of politics. As such, the problem political reconciliation confronts is how to transform a relation of enmity into one of civic friendship. Writing at the beginning of the twentieth century, Schmitt wants to bring the political to recognition against liberalism's inclination to obscure it by substituting procedure and interminable discussion for struggle between enemies. John Locke inaugurated this liberal tradition of political philosophy by articulating an ethic of toleration as response the violence associated with the Reformation in Europe. By returning to Locke, it becomes clear that an ethic of toleration seeks to contain the risk of politics by delimiting the legitimate ends of political action. Toleration enables coexistence between enemies by appealing to their reciprocal interest in security.

In this chapter we will see that an ethic of toleration is political insofar as it seeks to arbitrate conflict according to a standard that is immanent to the public realm. Moreover, it is predicated on an awareness both of the inevitability of plurality within the political association and of the potential for tyranny in claims to absolute truth in politics. However, I will argue that Locke conceives human interdependence too narrowly and so underestimates the creative potential of politics. In 2.1, I show how Locke seeks to derive a rational standard by which to determine the limits of political authority from the public good of security. In 2.2 I show how Locke's recommendation of toleration is supported by his epistemology. Given the limits of what we can know with certainty, we should maintain friendship in the diversity of opinions and refrain from imposing our own way of life on others. In 2.3, I discuss how Locke's social contract theory underpins the limited politics he advocates - the intent of which is to reduce its risks by excluding conflict over matters of faith from the public sphere. I 
conclude, in 2.4, that while toleration is important for establishing the minimal conditions for public communication between political antagonists, it tends to undercut political reconciliation by unduly limiting what may count as legitimate political speech. In order to keep a civil tongue it is necessary to avoid asking the embarrassing but inevitable question that political reconciliation must address: namely, who are "we"?

\subsection{The public good of security}

Locke was no advocate of absolute liberty in matters of religion. Rather, his main concern was the peace and security of the commonwealth (Kelly 1991: 132). Locke's great 'respect and veneration for authority' was a result of the civil discord and religious conflict through which he lived (PE: 7). This forced on him an awareness both of the risk of politics and of the fragility of society. 'I no longer perceived myself in the world,' writes Locke, 'but I found myself in a storm' and so 'cannot but entertain the approaches of a calm with the greatest joy and satisfaction' (PE: 7). The possibility of social disintegration as a consequence of political violence appeared very real to him (Schneewind 1994: 208). His argument for toleration, then, is associated with what Judith Shklar calls the 'liberalism of fear'.

Political liberalism's 'deepest grounding', Shklar (1989: 23) insists, is present in the 'conviction of the earliest defenders of toleration, born in horror, that cruelty is an absolute evil, an offence against God or humanity' (see also Wolin 1961: 293-294). Remembering wrongs perpetrated by past regimes, the political liberal anticipates the future more with fear than hope. Insofar as this liberalism makes a claim to universality it is not predicated on a substantive conception of the good to which all should strive but rather the recognition of 'cruelty and the fear it inspires' as an ultimate evil to be prevented at all costs (Shklar 1989: 29). ${ }^{1}$ I agree with Shklar that this 'deepest grounding' ensures liberalism's continuing relevance for the contemporary

\footnotetext{
${ }^{1}$ The fear the political liberal wants to prevent is that 'created by arbitrary, unexpected, unnecessary, and unlicensed acts of force and by habitual and pervasive acts of cruelty and torture performed by military, paramilitary and police agents in any regime' (Shklar 1989: 29).
} 
world, and, in particular, for polities divided by past wrongs. ${ }^{2}$ Yet, I will argue, this also makes toleration limited as an ethic that might animate reconciliation. By limiting the legitimate end of politics to the public good of security so as to mitigate against its risks, Locke under-estimates the creative potential of politics on which the possibility of reconciliation depends.

The fundamental problem that the issue of toleration poses for Locke is how to reconcile freedom of conscience with political authority (Kelly 1991: 127-128). As a puritan, Locke recognises the importance of freedom of conscience for sincere religious worship. However, he is suspicious of the claims of conscience in political life. ${ }^{3}$ Locke believes that there is a universal morality - the law of nature - that may be demonstrated by reason. However, he rejects the idea that the law of nature is written in our hearts by God and is revealed to the individual by his conscience. If practical principles were innate they would be self-evident to all. This is clearly not so since 'some Men, with same bent of Conscience, prosecute what others avoid' (E: 1.3.8). Conscience cannot provide an adequate criterion by which to determine the extent of political authority because judgements of conscience are self-validating, 'received upon their own Authority, without examination' (E 1.3.27; Kelly 1991: 131). Though conscience makes a claim to

\footnotetext{
${ }^{2}$ Locke's pragmatic justification of toleration differs significantly, in this regard, from the perfectionism of John Stuart Mill (Shklar 1989: 27; Waldron 1991: 111-112). While Locke argues against intolerance on the grounds that it leads to civil discord and political instability, Mill defends toleration on the basis that it is necessary for the flourishing of individuals as autonomous beings. Locke tends to present plurality as an inevitable aspect of human society that potentially leads to violent conflict. By contrast, Mill affirms plurality as a necessary precondition for human flourishing. This allows Mill to make a stronger claim about the immorality of intolerance than is apparent in Locke's appeal to political prudence (Mendus 1989: 55). However, the perfectionist argument for toleration runs into trouble since it presupposes a particular conception of the good (i.e. autonomy), which makes it less hospitable than political liberalism to forms of life that do not privilege autonomy. Consequently, both Mendus (1989: 70) and Shklar (1989: 30) suggest that Locke provides a more appropriate starting point for considering a theory of toleration suited to our present situation.

${ }^{3}$ The cultural crisis through which Locke lived was as epistemological as it was political. In a situation of fundamental disagreement over ultimate religious and moral truths there was no unified tradition to turn to in order to resolve disputes (Wolterstorff 1994: 173-174). Moreover, the Protestant emphasis on individual responsibility for salvation proved the ideal of a shared Christian conscience to be untenable as a basis for moral judgement. Far from being a unifying force, by which particular individuals came to the universal by listening to the voice of God within, conscience appeared a divisive principle, by which individuals mistook their partial opinions for the universal truth of God (Wolin 1961: 337; Kelly 1991: 130).
} 
universality based on the sanction of divine grace, the divorce of conscience from reference to a publicly accessible divine law means that only the individual to whom God speaks can judge the truth of his own experience. ${ }^{4}$ To elevate individual conscience over the authority of the sovereign is, then, to reject any public standard of reason (Kelly 1991: 126). To frame positive laws according to the judgements of conscience would be to abandon impartiality, which is the first principle of law (PE: 21, 140-141).

The claim of conscience, moreover, is open to abuse since individuals might appeal to religious reasons to justify the pursuit of worldly interests. For, 'how easily the pretence of religion, and the care of souls, serves as a cloak to covetousness, rapine and ambition' (L: 38). Whereas advocates of freedom are concerned to temper the power of the magistrate by appealing to individual conscience, Locke asks what bounds the people will put on their own consciences. If the people hear that the magistrate has no authority to impose in matters of religion 'they will all of an instant be converts, conscience and religion shall presently mingle itself with all their actions and be spread over their whole lives to protect them from the reach of the magistrate' (PE: 36). Freedom of conscience poses a threat to political order since it undermines the authority of the ruler, in whose care the peace of society has been placed. For it may be abused to justify the actions of 'everyone that could pretend to conscience and draw a sword' (PE: 42).

Related to this suspicion of mendacity is fear of irrational and boundless action that is nurtured by the politicisation of religious sentiment (see Creppell 1996: 213-216). The fervour with which religious faith is often proselytised threatens abandonment of rational debate and descent into violence (E: 4.18.11; 4.19.7). Claims of conscience often entail a dogmatism that leads to resentment of difference, for 'everyone is orthodox to himself', just as he appears a heretic to others (L: 14, 24). Consequently, freedom of conscience could 'prove only a liberty for contention, censure and persecution and turn us loose to the tyranny of religious rage' (PE: 7). This potential for violence is not inherent in Christianity itself, which is the 'most

\footnotetext{
${ }^{4}$ Locke is particularly critical of 'enthusiasts' for whom conscience is based on immediate revelation: 'This is the way of talking of these Men: they are sure, because they are sure: and their Perswasions are right, only because they are strong in them' (E: 4.19.9). 'It is a Revelation, because they firmly believe it, and they believe it, because it is a Revelation' (E: 4.19.10).
} 
modest and peaceable religion that ever was', but rather arises from the sinful nature of human beings (L: 51). Indeed, practice of the Christian virtues such as charity and peacefulness would foster the 'softness of civility' in political discourse (L: 23-27; T: 2.2.5, 2.8.108). This stands in contrast to the 'overheated zeal of those who know how to arm the rash folly of the ignorant and passionate multitude with the authority of conscience [which] often kindles a blaze among the populace capable of consuming everything' (PE: 55; L: 27).

The limits of government cannot be determined by the partial and corruptible judgements of private individuals, then, but must be grounded on an impartial and publicly accessible measure. The rule of law must prevail over the judgements of individual conscience (L: 44). The innovation that enables the development of Locke's thought on toleration is his transformation of the simple 'utilitarian justification' of the sovereign's absolute authority in the 'Two Tracts on Government' into a 'criterion for the legitimate exercise of power' in 'A Letter Concerning Toleration' (Kelly 1991: 139; see also Gough 1991). In his early writings, Locke defends the authority of the sovereign to impose in matters of religion because this is necessary for the maintenance of social peace and security (PE: 3-78). In the 'Letter' he argues that the actions and laws of the sovereign should be strictly limited to this end. While he revises his early defence of absolutism in favour of limited government, he continues to reject the partial judgements of religious conscience as a basis for determining the extent of the magistrate's authority (L: 44). Rather than freedom of conscience, the 'public good' should be the 'rule and measure of all law-making' (L: 33).

The public good of security provides a public standard of reason by which the limits of political authority can be judged. This is a view that contemporary liberals, such as John Rawls, continue to endorse. ${ }^{5}$ The end of political society is to secure for its members the 'just possession of things belonging to this life' ( $\mathrm{L}: 17)$. Both the boundlessness of conscience and the reach of political authority ought to be circumscribed by this rule. Each

\footnotetext{
${ }^{5}$ According to Rawls (1999: 187) 'this reliance on what can be established and known by all is itself founded on the principles of justice. It implies no particular metaphysical doctrine or theory of knowledge. For this criterion appeals to what everyone can accept. It represents an agreement to limit liberty only by reference to a common knowledge and understanding of the world.'
} 
person should be free to pursue his own eternal happiness as he thinks fit so long as this does not prejudice another person's rights or break the public peace (L: 39). Conversely, the actions and judgements of the sovereign are legitimate only to the extent that their purpose is to ensure the public good. If the sovereign oversteps the bounds of legitimate government by imposing religious practices irrelevant to the care of the commonwealth, the people have a right to revoke the office he has been entrusted with (T: 2.222).

In this light, religious toleration appears to be not only compatible with political authority but necessary for maintaining the peace and security of the commonwealth ( $\mathrm{L}: 49-50$ ). Since the sovereign has the coercive power of the state at his disposal, it is not the partiality of individual conscience but the partiality of government that constitutes the greater threat to the polity (T: 2.93). The unavoidable 'diversity of opinions' within society has not, in itself, been responsible for all the 'bustles and wars' that have afflicted the Christian world. Rather, violent conflicts have been fermented by 'the refusal of toleration to those that are of different opinions' (L: 52). Members of a minority sect are more likely to become dangerous to a political regime due to their shared persecution than their shared faith. There is 'only one thing which gathers people into seditious commotions, and that is oppression' (L: 49). By contrast, toleration is an appropriate policy by which to manage religious conflict and thus ensure the peace and security of a commonwealth (L: 49-50).

Though the principle of toleration is justified in terms of security, it is important to recognise that security, as the measure of legitimate government, is not an end in itself. Rather peace and stability are necessary conditions for the flourishing of human rationality and agency (Kelly 1991: 132). The 'end of the Law is not to abolish or restrain, but to preserve and enlarge Freedom' (T: 2.57). Government does not establish security simply so all can have a quiet and prosperous passage through this life but to maximise the conditions whereby individuals can find their way into the next (E: 1.1.5). Or, as John Rawls (1999: 187) was to later put it, 'the maintenance of public order is understood as a necessary condition for everyone's achieving his ends whatever they are (provided they lie within certain limits) and for his fulfilling his interpretation of his moral and religious obligations.' Yet, by conceiving the basis of political association minimally, in terms of a common 
interest in security, political liberals underestimate the potential of politics. Rather than look to politics as an activity through which individuals might discover the significance and meaning of their common existence, politics becomes, at best, a means that makes possible the private pursuit of happiness or, at worst, a direct threat to one's private happiness. This underestimation of the political follows from Locke's modest estimation of the horizon of human understanding.

\subsection{The limited horizon of human understanding}

How far human understanding can extend is a question of religious and political significance for Locke. By charting the 'Horizon....which sets the Bounds between the enlightened and dark Parts of Things; between what is and what is not comprehensible by us', he inquires into the 'human predicament, our place in the total scheme of things' (E: 1.1.7; Woolhouse 1994: 146). Given fundamental disagreement over ultimate values within society, Locke wants to 'find out those Measures, whereby a rational Creature, put in that State, which man is in, in this world, may, and ought to govern his Opinions, and Actions depending thereon' (E: 1.1.6). He concludes that our ignorance is 'infinitely larger' than our knowledge (E: 4.3.22). Yet, since we can know enough both for our purposes in this life and to find our way into the next, we should neither despair at the lack of certainty in human affairs nor pretend to greater certainty than we possess. Rather, we should patiently accept the limited understanding that our Creator has deemed sufficient for our worldly existence. The candle of reason that God has given us 'shines bright enough for all our purposes' since it provides us with 'light enough' to lead us both to the knowledge of our Creator and the sight of our duties (E: 1.1.5). ${ }^{6}$

\footnotetext{
${ }^{6}$ Wolin (1961: 296-297) comments: 'Where Plato had set as the target of human aspiration "the completest possible assimilation to god" and Aristotle had exhorted men "to put off mortality as far as possible", Locke had confined man to a middling sort of condition, incapable of omniscience or perfection, "a state of mediocrity, which is not capable of extremes..." The philosophy best suited to man's limited possibilities was one which concentrated on the "twilight of probability" between sceptical despair and proud presumption'.
} 
Knowledge, for Locke, refers to that which is 'certain and universal' or, in Aristotelian terms, to that which must be so and cannot be otherwise (E: 4.3.29). To know is, literally, to see truth and thus to be compelled by the 'irresistible Light of Self-evidence' or the 'force of Demonstration' (E: 4.19.1). To know by the force of demonstration is to perceive the necessary connection between abstract ideas, for example, that the three angles of a triangle are equal to two right angles. Locke is confident that many moral truths could be demonstrated with the same certainty as mathematical truths if men would only search after them with the 'same method and indifferency' (E: 4.3.20). Yet, what we can know remains fundamentally limited by our experience of the world, from which our ideas, the building blocks of knowledge, are originally derived. Consequently, we can discover only several basic truths of religion through reason operating independently of revelation. ${ }^{7}$

Due to the experiential limits of the understanding on the one hand and our 'laziness, unskillfullness or haste' on the other, we typically rely on opinion rather than knowledge in our everyday life (E: 4.14.3). We would have very little to guide our conduct in the world if we had to depend only on clear and certain knowledge (E: 4.14.1). For the most part, we conduct ourselves in the world by assenting to principles and facts without seeing, and hence being certain of, their truth (E: 4.14.1, 4.15.2). While God has 'set some Things in broad day-light', so that their truth might be revealed to us with certainty, for most of our affairs 'he has afforded us only the twilight...of Probability, suitable...to that State of Mediocrity and Probationership, he has been pleased to place us in here' (E: 4.14.2). In contrast to knowing, forming an opinion involves taking something to be true before seeing it to be so (E: 4.14.4). Most of the time opinion is all we have to go on. Nevertheless, in forming and holding beliefs we must let reason be our guide (Wolterstorff 1994: 178).

\footnotetext{
${ }^{7}$ Sam Black (1998: 479) refers to these as together constituting Locke's 'ultra-minimal creed', namely, that there is a God, that God is omnipotent, omniscient and providential, that this God should be worshipped and obeyed, that God has given us a law of nature and that the content of God's law is centrally connected with respect for property rights (E: 4.10.1-19). The truth of the ultra-minimal creed is not self-evident but must be demonstrated through the use of reason. Yet this is as far as reason can potentially reach in establishing certain religious truths; all else is necessarily a matter of faith.
} 
This account of the limits of understanding underpins Locke's argument for toleration. Though opinion provides us with a sufficient basis by which to govern our conduct, yet we should remain cognisant of its probabilistic status and, hence, of the potential fallibility of what we take to be true. Acknowledging the limits of human understanding in this way encourages an attitude of humility in our dealings with others. We should 'maintain Peace, and the common Offices of Humanity, and Friendship, in the diversity of Opinions' (E: 4.16.4). ${ }^{8}$ It is not so much scepticism, then, as anti-dogmatism that supports Locke's defence of toleration (Lowe 1995: 9). Against the humility of those who love the truth, Locke wonders at the 'extravagant arrogance' of those who hold their beliefs with absolute certainty, observing that those who cling most obstinately to their opinions are often those who have least examined them (L: 55; E: 4.16.3).

Locke's pragmatic defence of toleration is supported by two epistemological arguments concerning government fallibility and the irrationality of persecution. A sovereign ought not impose in matters of religion since his public authority does not provide him with any greater access to religious truth than is available to every private individual (L: 2930). In matters of faith, the judgements of the sovereign are as fallible and partial as anybody else's. This is evidenced by the diversity of statesupported religions. Ultimately, every individual must be the 'supreme and absolute authority of judging for himself' in matters of religion, since his soul depends on it (L: 43). The sovereign is not in a position to assume responsibility for the salvation of his subjects since it is not in his power to compensate for their loss should he err in his judgement of the true way to eternal happiness (L: 30 ).

Moreover, even if a sovereign did possess superior insight to religious truth, persecution is irrational because government cannot achieve the

\footnotetext{
${ }^{8}$ When engaged in dispute over matters of opinion we ought to 'commiserate our mutual ignorance' and seek to overcome it together by joining in the 'gentle and fair ways' of rational argument and 'not instantly treat others ill, as obstinate and perverse' because they will not readily receive our own opinion as their own. 'For where is the man that has incontestable evidence of the truth of all he holds, or of the falsehood of all he condemns, or can say that he has examined to the bottom all his own or other men's opinions? The necessity of believing without knowledge, nay, often upon very slight grounds, in this fleeting state of action and blindness we are in, should make us more busy and careful to inform ourselves than constrain others' (E: 4.16.4).
} 
professed end of saving souls by the coercive means at its disposal (see Waldron 1991). Subjects 'cannot be forced to be saved' due to the involuntary nature of belief ( $\mathrm{L}: 32,41)$. The coercive imposition of religious doctrines is intended to compel belief by working on the will. Yet, although a subject may outwardly conform through profession and practice, he cannot will himself to believe a proposition that he is not persuaded of. Belief is subject not to the will but the understanding. Only 'light and evidence can work a change in men's opinions; and that light can in no manner proceed from corporal sufferings, or any other outward penalties' (L: 19). Since salvation depends not on outward conformity but inward sincerity, it can be found only if the individual is free to follow his own conscience (L: 41). ${ }^{9}$

Underlying this pragmatic argument about the irrationality of persecution, then, is a moral one that appeals to the ideals of sincerity and thinking for oneself (Schneewind 1994: 202; Black 1998: 503). ${ }^{10}$ The individual must be the final judge in matters of religion not only because he would be foolish to trust the care of his soul to another, but because 'God meant us to think for ourselves' (E: 1.4.12; L: 18). We have a duty to seek religious truth and to examine the doctrines of our faith (L: 29, 42; E: 4.10.24, 4.17.24). Our highest obligation in this world is to obtain God's favour by inquiring after his purpose for us and leading our lives according to what we judge this to be. Indeed, the manner in which God is worshipped is, ultimately, less important than that he is worshipped sincerely (E: 4.10.3). As Robert Kraynak (1980: 66) observes, sincerity is the fundamental condition of liberal respect and it is in this context that the moral insult of intolerance is best understood. Though we may disapprove of another's religion we should respect that he practices it 'sincerely and out of conscience to God, according

\footnotetext{
${ }^{9}$ 'I cannot be saved by a religion that I distrust, and by a worship that I abhor...Faith only, and inward sincerity, are the things that procure acceptance with God...men cannot be forced to be saved whether they will or no; and therefore, when all is done, they must be left to their consciences' ( $\mathrm{L}: 32$ )

${ }^{10}$ Waldron (1991: 116) argues persuasively that Locke's argument about the irrationality of persecution is insufficient to justify the principle of toleration. Even though belief may not be subject to the will, we may wilfully direct our attention toward or away form things that are likely to confirm or disabuse us of our beliefs. In certain circumstances, then, it could be rational for a ruler to impose or prohibit practices or rites since this might indirectly influence a subject's beliefs by concentrating his attention. Waldron (1991: 120) concludes that it is not sufficient to assert the irrationality of intolerance; a stronger claim about its immorality is required. Yet Waldron overlooks this ethical moment in Locke's defence of toleration.
} 
to the best of his knowledge and persuasion' (PE: 140). For, since each worshipper believes he is performing those rites most pleasing to God, to impose any religious practice contrary his beliefs would be to require him to give offence to God (L: 35; PE: 139).

Locke's description of the tolerant person as a lover of truth who maintains peace and friendship in the diversity of opinions accords with the ideals of sincerity and thinking for oneself (E: 4.16.4, 4.19.1). The tolerant self is radically reflexive in that it takes a critical stance to its own experience; it can stand back from the self and its received opinions and examine them from the disengaged vantage point of reason. The tolerant self is not defined by its beliefs but defines these for its self. ${ }^{11}$ True freedom is realised in thinking for oneself rather than accepting, without examination, the opinions of others (E: 1.4.22). Though we are formed by passion, custom and education, our capacity to suspend assent and examine the grounds for it enables us to assume responsibility for the self and its beliefs (SS: 167). ${ }^{12}$ As Taylor puts it, 'radical disengagement opens the prospect of self-making' (SS: 170). In contrast to the enthusiast, who does not examine his opinions because he assumes they are God-given, the tolerant individual subjects his opinions to the 'restraint of reason' and 'check of reflection' (E: 4.19.6-7; T: 2.63).

Faith, then, must be regulated by reason. Reason and faith must be clearly distinguished, but they are not opposed to each other (E: 4.17.24). Whereas reason leads to knowledge or opinion based on sensation or reflection, faith leads to belief based on revelation (E: 4.18.2). Whatever God has revealed is certainly true. However, whether it has, in fact, been revealed

11 Taylor refers to the ideal of subjectivity that Locke inaugurates as the 'punctual self' (SS: 159-176; see also Tully 1993: 183-201). As Taylor puts it, '...the modern ideal of

disengagement requires a reflexive stance. We have to turn inward and become aware of our own activity and of the processes which form us. We have to take charge of constructing our own representation of the world, which otherwise goes on without order and consequently without science; we have to take charge of the processes by which associations form and shape our character and outlook. Disengagement demands that we stop simply living in the body or within our traditions or habits and, by making them objects for us, subject them to radical scrutiny and remaking' (SS: 174-175).

12 This stands in contrast to the greatest source of ignorance and error among humankind, 'the giving up our Assent to the common received Opinions, either of our Friends, or Party; Neighbourhood or Country. How many Men have no other ground for their Tenets, than the supposed Honesty, or Learning, or Number of those of the same Profession?' (E: 4.10.17). 
by God must be judged according to reason (E: 4.18.10). Faith should not convince us of anything that contradicts our knowledge because the assurance with which we judge something to be divinely revealed can never exceed the certainty of knowledge (E: 4.18.5). Faith is thus properly concerned with things 'beyond the discovery of our natural faculties' and, hence, 'above Reason' (E: 4.18.7). As such, our articles of faith must remain tentative for we can never be certain that they have been revealed to us by God. Faith may guide us in forming reasoned opinions but it cannot require us to abandon reason entirely. The failure to adequately distinguish these 'Measures and Boundaries between Faith and Reason' has been the cause of many 'great Disputes, and perhaps Mistakes in the World' (E: 4.18.1). The violence of the Reformation can be largely accounted for by the failure to regulate faith by reason due to the ill-informed belief that true faith requires the suspension of reason (E: 4.18.11). ${ }^{13}$

Locke's account of the limits of understanding thus leads him to recommend toleration as both virtue and institution. As virtue, toleration is associated with self-restraint. Awareness of the 'bounds' between knowledge and opinion leads us to 'govern' our opinions and actions, to 'regulate our assent and moderate our persuasion' according to the ideal of thinking for oneself $(E: 1.1 .6,1.1 .3)$. Psychologically, the violence of the Reformation could be explained by the fact that contradictory beliefs were taken on the authority of tradition or revelation to be certain truths for which men were 'ready at any time to seal with their Blood' (E: 1.3.27). By contrast the tolerant self does not take its beliefs on trust and authority but rather subjects them to suspension and examination (see Tully 1993: 193-201). Moreover, it does not mistake the probability of opinion for the certainty of knowledge. Reason thus imposes an 'economy of constraint' on religious belief and action (Creppell 1996: 202).14

13 As Selina Chen (1998: 178) observes: 'The distinction between faith and reason explains and justifies a pluralism of religious beliefs because conflicts about religious beliefs are not capable of adjudication by appeal to an external standard of judgement, given the low degree of probability they demonstrate.'

${ }^{14}$ In this context, Ingrid Creppell (1996: 202) argues that toleration 'was a freedom for the individual and a recognition of rights to moral expression, but it was also essentially dependent upon a domestication of that individual. The constraining or privatisation of moral life made a public openness possible. This establishment of boundaries between a political and private realm had ramifications not just "outside" between people, but within the person's psychological life.' 
This economy of constraint is institutionalised through the separation of Church and State. Establishing the limits of understanding leads Locke to advocate a limited politics. Those claims that cannot be arbitrated by recourse to a public standard of reason are omitted from politics. Since it is not possible to reach a substantive consensus concerning the good life, matters of faith are deemed private rather than public concerns. The public good of security acts as a principle of constraint that determines what is and what is not admissible as a legitimate claim in the public sphere. Conflicts arising from potentially incommensurable horizons of understanding are dealt with by limiting them to the private sphere. By limiting the scope of legitimate political action and judgement by recourse to a standard to which all can reasonably assent, the institution of toleration is supposed to manage irresolvable conflict between enemies. The public good of security provides a basis on which political antagonists can agree to disagree. As Bruce Ackerman (1992: 22) would later put, 'You and I may remain strangers, but we may find common ground in a politics that protects our equal right to cultivate our distinctive characters without any one stranger calling the shots. By working with one another to build a liberal state dedicated to our equal right to be different, we may become something more than strangers, if less than friends.'

\subsection{Limited politics}

Lockean toleration and the liberalism of fear are predicated on a juridical political morality. Will should be restrained by reason, politics by the law. Just as it is essential for the self-governing subject to clearly distinguish the proper 'measures and boundaries' between faith and reason, it is imperative for the peaceable government of society to 'settle the just bounds that lie between' Church and State (E: 4.18.1; L: 17). The establishment and preservation of enduring political institutions depends on containing irresolvable religious controversies. This is achieved by maintaining a clear separation between religious and political society. Locke takes Church and State to be 'absolutely separate and distinct' both in terms of the ends for which they are instituted and the authoritative means by which they govern their members' lives (L: 26). The violence of the Reformation can be 
explained, in this context, by wrong-headed efforts to subordinate political means (coercion) to religious ends (salvation) on the one hand or religious means (indoctrination) to political ends (security) on the other. By contrast, if each society would 'contain itself within its own bounds', with the church attending only to the salvation of souls and the state to the welfare of the commonwealth, much civil discord could be avoided (L: 53).

Religious society exists for the 'public worship of God, and by means thereof the acquisition of eternal life' (L: 20). All the discipline and laws of the Church, therefore, ought to be confined to this end, to 'the regulating of men's lives according to the rules of virtue and piety' (L: 14). None should relate to the 'possession of civil and worldly goods' (L: 22). Since religious society is not concerned with worldly goods, it has no legitimate claim to the use of coercion against its members, or anyone else (L: 20). A Church is a 'free and voluntary' association of individuals who unite to worship God in the manner they believe most pleasing to him (L: 20). Consequently, religious authority resides in the common consent of the members of a Church to abide by its laws; God does not directly invest authority in a minister or bishop. Compliance with the laws and doctrines of a particular Church may be sought, therefore, only through the use of 'exhortations, admonition and advice', which, in any case, are the only effective means to influence the understanding of others (L: 22). Ultimately, the strongest sanction available to Church authorities is excommunication.

By contrast, political society exists for 'no other end but to secure every man's possession of the things of this life' (L: 44; T: 2.95). The role of government, therefore, ought to be limited to providing for the public good. The sovereign is 'armed with the force and strength of all his subjects' in order to preserve the commonwealth from external threats and to punish those who violate the rights of others ( $\mathrm{L}: 17 ; \mathrm{T}: 2.131$ ). Yet, the civil power of the sovereign must be 'bounded and confined' by this end (L: 18). Political society does not exist for saving souls (L: 18, 28), making men morally good (L: 38-39) or establishing religious truth (L: 41). Since none of these are necessarily entailed by the public good of security, they are illegitimate ends of the state. 
Locke's argument for instituting toleration by limiting politics is supported by his social contract theory of the origin, extent and end of civil government. The legitimate scope of political authority is demonstrated by imagining our situation in a state of nature in which individuals co-exist without a publicly recognised authority to judge between them. In this state of nature, people are without government but not without law. Individuals live in perfect freedom (no-one is subject to the rule of another) and perfect equality (all have the same authority to adjudicate and enforce the law). The state of nature, then, is not a war of all against all (T: 2.19). Rather, individuals know and obey the law in the absence of an over-reaching authority. ${ }^{15}$ The law of nature can be known by all 'who will but consult it' through reason and it teaches that 'being all equal and independent, no one ought to harm another in his Life, Health, Liberty, or Possessions' (T: 2.6). Put simply, the law of nature is the public good: 'that measure God has set to the actions of Men, for their mutual security' $(2.8 ; 2.11 ; 2.135)$. This law is universal in that it extends to all, can be known by all and obliges all; the natural society of human beings encompasses all humanity ( $T: 2.128$ ).

The law of nature commands the subjection of will to reason. We restrain our will within the limits of the law due to our recognition that individual freedom depends on common observance of the law. When an individual transgresses the law of nature he therefore 'declares himself to live by another Rule than that of reason and common Equity' (T: 2.8). He places himself outside society, renouncing reason and reverting to force - the way of beasts (T: 2.172). Every individual in the state of nature has the right to punish someone who violates the law. For the offender not only wrongs his victim but trespasses 'against the whole Species' by violating the law that constitutes society (T: 2.8). Locke's idealised account of the state of nature as a pre-political state in which men live 'together according to reason, without a common Superior on Earth' is a description of the conditions in which God places human beings in the world (T: 2.19; see Ashcraft 1994: 238; Dunn 1994:

\footnotetext{
${ }^{15}$ Locke shares the 'basic assumption' of all juridical political thought that law constitutes society. That is, 'in virtue of being subject to law in a law-governed community, people are social, moral, and rational beings' (Tully 1993: 24; T: 2.11). However, against legal positivists such as Hobbes and Schmitt, human nature is not naturally base so that moral life is conditional on the establishment of law by a juridical political authority (T: 2.92). Rather, human beings are naturally sociable in the strong sense of not just needing to enter society for self-preservation but to enjoy each other's company ( $\mathrm{T}: 2.77$ ).
} 
47). Individuals are in the great society of all humanity prior to the establishment of political authority. Contrary to Hobbes (and Schmitt), therefore, society is not realised by political means but, rather, precedes political authority.

Juxtaposed against this idealised state of nature, which is characterised by 'Peace, Good Will, Mutual Assistance and Preservation', is the state of war, marked by 'Enmity, Malice, Violence, and Mutual Destruction' (T: 2.19). The state of war is brought about by 'force, or the declared design of force' intended to bring the other under absolute subjection in the absence of a 'common Superior on Earth to appeal to for relief' (T: 2.19). The state of war is an aberration of society, whether the prepolitical society of humankind in the state of nature or the civil society of men within a polity. It is an aberration in that it destroys the agreement to live by a common law (natural or positive) that makes society possible. This agreement is destroyed whether the enemy acts 'outside' the law by disregarding it or 'through' the law by perverting it into an instrument of oppression ( $\mathrm{T}: 2.20$ ).

As Sheldon Wolin (1961: 306f.) points out, these contrasting pictures of the perfect state of nature and the state of war present an interpretative difficulty regarding which condition political society is realised from. For, given the ideal (though inconvenient) conditions in the perfect state of nature, it is difficult to understand why people would want to leave it to enter political society. Yet if political society is instituted from the state of war, it appears impossible to resist the Hobbesian conclusion that society can only exist where there is a strong authority capable of over-powering all. In this context, Wolin points to a 'third condition' implicit in Locke's historical account of the origin of political society, which he refers to as the 'fallen state of nature'. Though the natural society of human beings is the 'great and natural Community' of humanity, individuals were driven to separate from this and 'by positive agreements combine into smaller and divided associations' due to the 'corruption, and vitiousness of degenerate Men' (T: 2.128).

Though the original condition in which God places men in the world is one of perfect freedom and equality, this condition becomes 'full of fears 
and continual dangers' due to the human propensity to sin ( $\mathrm{T}: 2.123$ ). In contrast to the ideal state of nature in which reason rules the wills of men, then, in the fallen state of nature the operation of reason is corrupted by selflove. Ironically, although Locke turns to reason (against tradition or revelation) in order to establish the legitimate end of politics in a plural society, he remains pessimistic about the capacity of men to know those basic moral truths that provide the foundation of the polity. Working people lack the skill and time to employ their reason to the attainment of knowledge (E: 4.15.6, 4.10.2). ${ }^{16}$ Moreover, the understanding of most is corrupted by 'desire of esteem, riches, or power', which leads them to distort the truth or use it for their own ends (E: 4.2.20; L17). Rather than being rational interpreters of the law of nature, in their fallen state individuals tend to be partial in their own cases and those of friends. Similarly, passion and revenge carry them too far in punishing those enemies who trespass against them (T: 2.13, 124, 136).

For Locke, then, human beings are driven into political society by insecurity. Remembrance of the original condition in which God placed men in society together enables them to recognise the deficiencies of their fallen state and suggests the 'remedies' by which these may be overcome in civil society (Wolin 1961: 307). An established and public law, a public and impartial judge and the power to enforce justice - those conditions that were present in the ideal state of nature but found wanting in the fallen state of nature - are restored in political society (T: 2.124-6). The body politic is constituted by the common consent of its members to be governed according to the public good. Men agree to divest themselves of their natural freedom and 'put on the bonds of civil society' for their 'comfortable, safe and peaceable living one among another, in a secure Enjoyment of their Properties, and a greater Security against any that are not of it' (T: 2.95). The establishment of an impartial political authority provides the remedy for those evils that arise in the fallen state of nature, where individuals are judges in their own cases ( $\mathrm{T}: 2.14$ ). The advantage of political society, then, is that individual partiality, which is an inherent human weakness, is mitigated

\footnotetext{
16 The public good is a matter of knowledge rather than opinion since it is to be found in the law of nature, which is 'plain and intelligible to all rational Creatures' (T: 2.9.124). However, since the truth of natural law is not self-evident but must be demonstrated, to know it requires an exacting sort of intellectual inquiry. As Wolin (1961: 335) puts it, 'The law of nature was viewed as a body of essential political truths, discoverable by reason, yet there was the difficulty that, for the vast majority, human reason had been corrupted'.
} 
by authorising an indifferent third party as representative of the community to impartially arbitrate public conflict (T: 2.89 ; L: 17, 51).

However, if the advantage of government is that it improves the prospects for civil peace through impartial interpretation and enforcement of law, the risk it brings is the potential for abuse of that political power concentrated in the office of the sovereign ( $\mathrm{T}: 2.13$ ). While the partiality of individuals led to insecurity in the fallen state of nature, the partiality of a sovereign poses an even graver threat to society (T: 2.90-94; see Dunn 1994: 49f.). Not only the will of subjects, therefore, but the will of the sovereign must be restrained by the law (T: 2.94). The authority of the sovereign is that of a 'publick Person vested with the Power of the Law' (T: 2.151). Consequently, if the sovereign acts outside the law, if he imposes his own private will rather than governing impartially according to the public good, he acts 'contrary to the trust reposed' in him by the people (T: 2.149, 151). The arbitrary exercise of power dissolves the authority entrusted in the sovereign by society and so places him in a state of war with those he unjustly persecutes. In the absence of an impartial authority to appeal to, the right of the people to ensure their self-preservation is returned to them. The people thus have the right to resist tyranny, which comes about when the sovereign 'makes not the Law, but his Will, the Rule' (T: 2.199).

If Locke's epistemology establishes an obligation to maintain friendship in the diversity of opinions, his social contract theory recommends the institutional arrangements by which this is possible. The institution of toleration through the separation of Church and State is the historical precedent of the modern liberal distinction between private and public. This distinction supports not just a theory of limited government but a limited (and limiting) understanding of the political. The ideal of limited government is predicated on fear of the boundlessness of tyrannical will and subjective conscience. Since politics is synonymous with the coercive power of government, the limits of the political are demarcated in order to prevent it from encroaching on society. The political therefore comes to reside in the 'sum of protective arrangements' that leaves individuals free to pursue their own private happiness (Wolin 1961: 302). When politics goes well it establishes the social conditions under which individuals can pursue their 
private happiness. When it goes wrong it threatens to destroy society through violence.

As Wolin (1961: 308) argues, Locke initiates 'a way of thinking in which society, rather than the political order, [is] the predominant influence'. This is reflected in Locke's characterisation of the state of nature as one of society rather than war. With the rejection of the nature-society dichotomy, the political order loses its 'quality of dramatic achievement'. It is not the establishment of a political order that brings society into existence but society that precedes and sustains politics. Thus, politics is not conceived in terms of invention but a recovery of our natural condition (Wolin 1961: 306). Rather than looking to politics to realise society, the political liberal tends to presuppose society as that which must be protected by and from politics. It is in society, despite politics, that he hopes to realise freedom and happiness.

The political liberal is right to emphasise that limiting politics opens a space for friendship in the diversity of opinions. Some bounds must be set around the political. However, how and where the limits should be drawn is itself a political question. Locke supposes that the distinction between public and private can be reasonably established by recourse to the public good of security. The rule of law determines the limits of the political. Thus, the political authority has 'no Will, no Power, but that of the Law' (T: 2.151). This marks Locke's fundamental departure from Hobbes. Whereas for Hobbes law is established by the will of Leviathan, for Locke political will is legitimate only if it conforms to the law. It is this liberal faith in the rule of law that Schmitt attacks when he argues that the law is always allied to a regime of politics; the legal order 'rests on a decision not on a norm' (PT: 910). I agree with Schmitt that it is implausible to suppose that the principle of security can furnish a non-political criterion by which to determine the limits of the political. For this public good is routinely appealed to by both liberal and non-liberal regimes to curtail basic human freedoms. Security, like reconciliation, is an essentially contested concept within political discourse. Though all agree it is good, actors mean different things when they affirm their commitment to it.

My point here is not to debunk security, impartiality and limited government as important values of public life but to show the limits of 
toleration as an ethic that might animate political reconciliation. Toleration seeks to contain the risk of politics by depoliticising conflict over ultimate ends, which might give rise to enmity. This is achieved, importantly, by the institution of 'gag rules.' In this context, Stephen Holmes (1988a: 23) observes that 'the "wall" between church and state does not merely shelter the private sphere from unwanted incursions; it also unburdens the public sphere of irresolvable problems.' ${ }^{17}$ Similarly, Erin Kelly \& Lionel McPherson (2001: 51) argue that in political discourse 'people should not invoke comprehensive moral doctrines or religious beliefs as justifying reasons - and debate should not extend to issues that do not require political resolution.' Yet it is precisely such conflict that also holds out the possibility of transforming a relation of enmity into one of civic friendship. Ultimately, the problem with positing the public good of security as the basis for a limited politics, then, is that it begs the question of how this society should be secured. By limiting politics to the end of security, toleration forecloses a politics that would enable citizens to call into question (and so potentially discover reasons) why they should want to collectively secure the conditions that make society possible between them in the first place.

Toleration thus tends to undercut the possibility of reconciliation by denying its status as a legitimate political aspiration. Timothy Garton-Ash (1997: 37), for instance, argues that 'taken to the extreme' reconciliation is a 'deeply illiberal idea. As Isaiah Berlin has taught us, liberalism means living with unresolvable conflicts and South Africa has those in plenty.' Consequently, he wonders if it would it not be 'more realistic to define a more modest goal: peaceful coexistence, cooperation, toleration?' 18 'What is clear', Berlin (1990: 12) insists, 'is that values clash - that is why civilisations are incompatible.' Consequently, 'we can discuss each other's point of view, we can try to reach common ground, but in the end what you pursue may

\footnotetext{
17 As such, Holmes (1988a: 24) insists, 'private rights contribute vitally to democratic government by expunging irresolvable disputes from the public sphere. By narrowing the scope of the political agenda to problems manageable by discussion, certain individual rights may be said to subserve self-government.'

${ }^{18}$ Similarly, De Brito et al (2001: 27) suggest that: 'Rather than talk about reconciliation, it is more appropriate to ask whether accountability processes can contribute to affirming democratic governance... Unity may be elusive and even undesirable if it is conceived of in a non-democratic way. By contrast, consensus around the need for democracy, for a system of rules, laws, procedures, and values that calls for peaceful coexistence among all kinds of groups, whether friendly or not, is a lower threshold and a more practical possibility.'
} 
not be reconcilable with the ends to which I find that I have dedicated my life' (Berlin 1990: 12). As such, political liberalism is conditioned by an awareness of the risk of politics, the potential irreconcilability of politics.

Yet, this results in a suspicion of politics that leads liberals to neglect the opportunities (as opposed to the dangers) that the clash of ideals presents. Berlin (1990: 13) insists that, to those who advocate an ideal of reconciliation 'we must say that the world in which what we see as incompatible values are not in conflict is a world altogether beyond our ken...But it is on earth that we live, and it is here that we must believe and act.' Consequently, the 'best that can be done, as a general rule, is to maintain a precarious equilibrium that will prevent the occurrence of desperate situations, of intolerable choices' (Berlin 1990: 17-18). Political liberals are rightly worried about the danger of conceiving reconciliation as an ideal end of politics. Against such a lofty aspiration, they want to limit the aim of politics to avoiding the worst. However, they give up too much in rejecting reconciliation as a horizon of potentiality against which politics might be enacted. For, in the absence of a meta-political standard on the basis of which the terms of association could be delimited, the aspiration to reconcile provides a context in which citizens might struggle to find good reasons to want to live together in the first place.

\subsection{The limit of toleration}

Toleration may be necessary, then, but it is not a sufficient basis for political reconciliation. In order to open a space for politics it is important to limit the conversation, to set bounds to the scope of legitimate claims and to establish public procedures for settling controversies. Yet the possibility of calling these limits into question, of politicising the terms of association, must be held open. Since the political liberal looks to politics with fear rather than hope, toleration is premised on an understanding of the political that is too restrictive. Although toleration establishes a basis on which members of a plural society might peaceably coexist, it limits politics in such a way that it renders citizens inarticulate about how society is possible in the first place.

By precluding comprehensive moral doctrines and religious beliefs as legitimate reasons for political action and judgement, it limits the possibility 
of the kind of political engagement between friend and enemy through which self-understandings might be transformed. Toleration seeks to evade the risk of politics by avoiding the embarrassing question of who "we" are. Yet, it is precisely this issue of identity and belonging - the ethical constitution of a "we" - that is at the heart of political reconciliation.

The limit of toleration is revealed in the refusal of toleration to the intolerant and unreasonable. Locke argues that toleration should not be extended to Catholics or atheists. This is justified on the basis that no opinions 'contrary to human society, or to those moral rules which are necessary to the preservation of civil society are to be tolerated by the magistrate' (L: 45). For Locke, the existence of God is a demonstrable truth. Atheism, therefore, is not only immoral but irrational. Moreover, in Locke's view, the 'taking away of God, though but even in thought, dissolves all' (L: 47). Without belief in a God who dispenses reward and punishment in the after-life people would have no reason to be moral. Atheists, then, should not be tolerated because they cannot be trusted to keep the promises, covenants and oaths that are the 'bonds of human society' (L: 47). Similarly, Catholics cannot be trusted, though for different reasons. Catholics make bad citizens because they recognise a political allegiance to the Pope, which might come into conflict with that of the sovereign. As such, Catholics are a potential fifth column within the body politic. Moreover, the Pope's claim to temporal authority extends not just to Catholic subjects but to heretics. Whereas atheists should not be tolerated because they imperil society by their unreasonable denial of the existence of God, Catholics should not be tolerated because they imperil society by their intolerant refusal to recognise fully the separation of Church and State.

On Locke's own self-understanding, his intolerance of atheists and Catholics is not based on prejudice. Rather, Locke offers what he considers to be universalisable reasons for limiting toleration. In principle, Rawls (1999) takes the same position when he argues that it is only the liberty of the intolerant which is to be limited, and this is done for the sake of equal liberty under a just constitution the principles of which the intolerant themselves would agree to in the original position.' Selina Chen (1998: 183) points out that 'had Locke believed, as most of us do now, that it is rational to behave morally without theistic beliefs, he would have no reason for excluding 
atheists from freedom and citizenship.' Similarly, it is likely that Locke would also have included Catholics in the tolerant society had the Papacy renounced all temporal authority and taught Catholics unconditional obedience to the sovereign. Yet these historical examples are instructive in that they reveal liberalism's tendency to overlook the political nature of its own exclusions. Locke (like Rawls after him) assumes that humans reason in the same way and that reason exists independently of tradition, prejudice and custom. Yet it is clear to us that Locke's argument for excluding Catholics and atheists in the name of toleration is embedded in a peculiarly Protestant worldview.

Thus, although Locke assumes that membership in the tolerant society is predicated on terms that are established by an impartial and public standard of reason, we can see that they are inherently political in a Schmittian sense. The light of reason is supposed to compel assent, yet if atheists resist seeing the truth of God's existence, it is legitimate to coerce them by political means. Similarly, if Catholics resist the ideal of the Church as a voluntary association and stubbornly cling to traditional authority, there is no obligation to extend tolerance toward them. Atheists and Catholics are excluded because they are recognised as enemies of society. I draw attention to Locke's own intolerance, here, not because I want to argue that toleration should be limitless. Rather, my point is that we should recognise the political nature of where the limit of toleration is drawn - that the grounds for exclusion depend on the regime within which toleration is instituted. By contrast, the claim of the political liberal to delimit the scope of legitimate political conflict by reference to a non-political standard 'reveals itself to be not the opposite of force, but a force that outlaws opposition' (Rasch 2000: 10). For, as Emilios Christodoulidis (1998: 280) observes, 'to fix the boundaries of possible politics metapolitically...is itself a silencing of politics. ${ }^{19}$

\footnotetext{
${ }^{19}$ Similarly, Chantal Mouffe (2000: 31) argues, political liberalism denies its own exclusions by 'declaring that they are the product of the "free exercise of practical reason" that establishes the limits of possible consensus. When a point of view is excluded it is because this is required by the exercise of reason; therefore the frontiers between what is legitimate and what is not legitimate appear as independent of power relations. Thanks to this legerdemain, rationality and morality provide the key to solving the 'paradox of liberalism': how to eliminate its adversaries while remaining neutral.'
} 
The limit of toleration is further revealed in the example of a calfsacrificing sect that Locke introduces in order to demonstrate the principle of state impartiality. For Locke, impartiality means that the sovereign should not engage the particular meanings that groups attach to particular practices. Rather, he should appeal to public and universal reasons to justify state action. Thus, if it is lawful for an individual to slaughter and burn a calf at home he should be allowed to do so in Church. The sovereign would not be justified in prohibiting the religious sacrifice of calves if he continues to permit their domestic slaughter. However, it would be legitimate for the sovereign to universally prohibit the slaughter of calves for a certain period if this is justified by appealing to the public good, for example, in order to ensure the replenishment of stock. Although this policy would have a disproportionate impact on members of the calf-sacrificing sect, the sovereign would be justified since the law would be made about an economic rather than a religious matter (L: 37).

As Jeremy Waldron (1991: 112-115) discusses, what matters to Locke are not the effects of state coercion but the reasons that justify it. Though a prolonged prohibition of calf slaughtering may threaten the cultural survival of the calf-sacrificing sect, this is judged to be a tolerable consequence in the interest of the public good. What is important is that there is no wilful discrimination against a group of people on the basis of its particular form of life. By contrast, for the perfectionist liberal - who takes diversity to be a precondition for human flourishing - impartiality would entail not just a negative responsibility of non-interference but a positive obligation to protect and preserve cultural diversity. This demands more than simply ensuring the equity of consequences as well as reasons for state coercion, as Waldron (1991: 113) suggests. This stronger principle of impartiality would appear to require not only justification in terms of universal reasons but that the sovereign enter into to the particular self-understandings of subjects in order to properly appreciate the significance of his actions. On this account, state impartiality may in fact require discriminating between different forms of life in order that to ensure their survival. Against Locke, impartiality might require allowing the sacrifice of calves to ensure the survival of the religious 
sect, while prohibiting their slaughter for domestic consumption in order to allow the replenishment of the national stock. ${ }^{20}$

An ethic of toleration seeks to overcome the friend-enemy relation through the reasoned acceptance by each party of their common interest in security. The political conflict that arises due to the clash between the partial opinions of people is mitigated by recognising an overarching interest in peace. Through the use of reason, individuals are able to stand back from their prejudices and beliefs for long enough to recognise their individual interests in security as a shared interest. Society with the other can be reasonably countenanced, on the basis of a shared interest in peace, so long as politics is limited to serving this end. Yet, as Bert van Roermund (2001: 187-190) discusses, an ethic of toleration is insufficient to sustain political reconciliation if politics is limited to 'restoring' the rule of law as conceived within the social contract tradition. For in the circumstances in which a reconciliatory politics is enacted, 'law can only be established on the ruins of an oppressive past. What is more, it can only be enacted and enforced between parties whose identity is mutually related to their respective roles in this past. For all of them, to live under the rule of law is to engage in the daily effort to find good reasons to do so' (van Roermund 2001: 187). The common interest in security cannot, in itself, furnish a public standard of reason by which to determine the end and limit of the political. For the transition with which a politics of reconciliation is concerned is not from the state of nature but from a state of oppression to the rule of law.

Given the legacy of grave state wrongs, the establishment of a tolerant society will require more than an appeal to a common interest in security. ${ }^{21}$

\footnotetext{
${ }^{20}$ But such a principle of impartiality cannot be justified within the terms of political liberalism. Rather, it is sustained by a politics of recognition. Galeotti makes this point in relation to a recent controversy in France surrounding Muslim girls who refused to lower their headscarves during class. This was interpreted by the school and state authorities as a challenge to the principle of secular education. Galeotti argues that the limit of toleration arises because liberalism conceptualises difference as a matter of individual choice rather than collective identity. Consequently, an ethic of toleration does not provide the basis on which to 'differentiate meaningfully between wearing the Islamic veil and wearing a funny hat at school' (Galeotti 1993: 586; see also Moruzzi 1994; Galeotti 1994; Koker 1996). Similarly, Walzer (1997: 69) argues that 'claims of conscience over a wide range of social issues...gain whatever legitimacy they have, even today, because they are religious practices, features of a collective way of life. These practices would have no legitimacy at all if they were put forward on a purely individual basis'.
} 
For the wrongs of the past were likely to have been 'justified' in similar terms. 'In politics, oppression is accompanied invariably by the claim that it occurs on behalf of the public order or the general interest' (van Roermund 2001: 176). Part of the polity is subjected in order to maintain the security of the whole. Consequently, reconciliation must come to terms 'not only with the violence of the past, but also with its alleged justification' (van Roermund 2001: 176). This requires more than the benign indifference of toleration. It requires a substantive engagement between conflicting world-views from which a shared horizon of understanding might emerge. Van Roermund (2001: 188) suggests (with some scepticism) that the Hegelian dialectic of master and slave might provide an alternative to social contract theory as a basis for imagining the possibility of political reconciliation. It is fitting then, that we should consider next whether an ethic of recognition, as articulated by Charles Taylor, might furnish a more adequate basis for political reconciliation than is afforded by Lockean toleration.

21 'The problem,' Michael Ignatieff (1999: 92) observes, 'is that before you can have tolerance, as a social practice, you have to create a political culture in which human identity itself is seen as individual and civic, rather than ethnic and collective. Transition to democratic regimes can occur almost overnight. The transition to a democratic culture, tragically, requires time, peace and prosperity, and all three are in short supply in Eastern Europe.' Ignatieff puts his finger on the problem with toleration here, but against such liberal complacency, I will suggest in the following chapter that political reconciliation needs the rough ground of ethnic and collective identities in order to get started. 


\section{Recognition}

In chapter one I insisted that a politically adequate conception of reconciliation must be conditioned by an awareness of the risk of politics, which, following Schmitt, we saw to be the ever-present possibility of the friend-enemy relation. Consequently, political reconciliation must be understood not in terms of restoring community between alienated comembers but in terms of transforming a relation of enmity into one of civic friendship. We have just seen that an ethic of toleration seeks to contain the risk of politics - and, thus, to domesticate an antagonistic relation between enemies - by limiting the legitimate end of the political association to the public good of security. By demonstrating a reciprocal interest in security, Locke hopes to provide common ground on which former enemies can agree to disagree. However, toleration tends to elide rather than contain the risk of politics because it cannot acknowledge the political nature of its own exclusions. Moreover, this limited politics precludes the kind of agonistic confrontation in which former enemies might discover good reasons to want to live together in the first place.

If an ethic of toleration would enable enemies to coexist by depoliticising conflict over ultimate ends, an ethic of recognition hopes to realise community between enemies by transforming their antagonism into a reciprocal dialogue oriented towards a shared understanding. In this chapter, I will show that Charles Taylor provides a richer account of political interdependence than is afforded by social contract theory because he recasts political conflict as ethical and integrative. Yet, as I argue in 3.1, a politics of recognition tends to trade on an ambiguous account of identity as both constituted through dialogue with others but also somehow fundamental and non-negotiable. Consequently, as we will see in 3.2 and 3.3, a politics of recognition tends to presuppose identity both as an origin to which we should be true and as a communal end that is the inevitable outcome of 
interaction. While the ideal of authenticity tends to reify existing identities as irreducibly social goods, the ideal of a fusion of horizons makes an unwarranted presumption that conflict will end in community. Frantz Fanon is important, in this context, in drawing our attention to a certain antipolitical moment that is inherent to relations of recognition. I conclude in 3.4 that recognition is both a necessary and untenable basis for political reconciliation. For although it provides the rough ground in terms of which an ethical encounter between former enemies becomes possible it tends to over-determine the terms in which a reconciliatory politics would be enacted.

\subsection{The irreducibly social good of identity}

The politics of recognition is predicated on the idea that identity is an irreducibly social good and that, since our identities are formed through social relations, misrecognising the particular identity of the other can be a form of oppression (PA: 232). Consequently, we have an obligation to recognise the other in terms of her own self-understanding rather than by imposing our own form of life and cultural norms upon her. Charles Taylor articulates his ethic of recognition in the context of debates about multiculturalism in North America and, in particular, the status of Quebec as a distinct society within the Canadian federation (see especially PA: 242f.; RS: 168-170, 192-193). Yet, he also points beyond Canada to the anti-colonial struggles of the post-war period as the context within which the harm of misrecognition was first clearly articulated and made a rallying point in the politics and wars of liberation. According to Taylor, Frantz Fanon popularised the idea that misrecognition constitutes a harm of the same order as exploitation, injustice and inequality (PA: 250-251).

Influenced by Sartre's pessimistic reading of Hegel, Fanon (like Albert Memmi) argues that colonial rule is sustained and legitimated by a pattern of non-recognition predicated on the destruction of the culture of the colonised and imposition of the language, institutions and history of the colonisers. ${ }^{1}$

\footnotetext{
1 'We witness the destruction of cultural values, of ways of life. Language, dress, techniques, are devalorised...Expropriation, spoliation, raids, objective murder, are matched by the sacking of cultural patterns, or at least conditions such sacking. The social panorama is destructured; values are flaunted, crushed, emptied...In their stead a new system of values is
} 
The colonised are misrecognised in terms of the norms and meanings of the hegemonic culture. While the colonisers represent themselves as civilised, cultured, rational, enlightened, sophisticated and industrious, the colonised are identified, through a series of negations as 'not-us': uncultured, uncivilised, irrational, backward, childlike, lazy (Memmi 1990: 149). The colonisers are not content to be masters by force alone but need to legitimate their rule by convincing the colonised to accept their role as slaves (Memmi 1990: 155). The denigrating identification of the colonised inflicts harm by imprisoning them in a 'false, distorted and reduced mode of being' (PA: 225). Persistently bombarded with a demeaning portrait of themselves, the colonised end up accepting and learning to live with it as one does a 'detested nickname which has become a familiar description' (Memmi 1990: 153). Distorted by colonial misrecognition, the identity of the colonised becomes a source of shame (Fanon 1967: 38).

Taylor's description of the harm of misrecognition in terms of imprisonment is meant to convey how the loss of self-worth wrought by the denigration of one's identity is accompanied by a diminished sense of agency. ${ }^{2}$ Since the colonised are made complicit in their own oppression through their internalisation of a demeaning self-image, the first step of liberation is to reclaim their identity as a source of pride rather than shame. Fanon (1965: 238) advocates revolutionary violence as a means for the colonised to reclaim their agency. Yet, if reconciliation with the colonisers is sought, rather than their elimination and expulsion, then this might be conceived in terms of a struggle for recognition of a newly asserted positive self-image. Indeed, it is this more optimistic reading of the master-slave dialectic as being oriented to the realisation of 'a regime of reciprocal recognition among equals' that underpins Taylor's own analysis of identity politics in the contemporary world (PA: 241).

imposed, not proposed but affirmed, by the heavy weight of canons and sabres' (Fanon 1967: 33-34).

2 This metaphor resonates in Fanon's (1965: 46, 170, 73) description of the colonised as being 'hemmed in', held in the 'grip' of colonialism, suffering from 'petrifaction' and 'cultural lethargy'. Misrecognition 'snares', 'imprisons', 'walls in', 'chains', 'hamstrings', 'seals' and 'fixes' the individual within a reductive social category (Fanon 1986: 35, 112, 117, 130, 109). Similarly, Memmi (1990: 203) writes of the 'moribund culture', 'frozen traditions' and 'rusted tongue' of the colonised. 
Taylor's account of the harm of recognition turns on his communitarian understanding of the importance of identity in moral and political life. ${ }^{3}$ In contrast to Locke's ideal of the tolerant self as a knowing subject that exists independently of its social context, prejudices and beliefs, Taylor emphasises the dialogical character of human existence. Our personal and public lives are characterised by our situation within 'webs of interlocution' in which we struggle to define ourselves with and against significant others (SS: 36-38; PA: 230). Individuals are dependent on their intersubjective relations with others for acquiring a sense of self (PA: 226). Through perceiving ourselves as others perceive us we acquire selfconsciousness, the capacity for self-reflection (see also Honneth 1995: 74). Recognition by others does not passively reflect back our self-interpretations, then, but actively shapes the way we think of our selves: it 'forges identity' (PA: 251). While our basic self-confidence depends upon loving recognition in our private relations, in the public sphere recognition takes two forms (PA: 233). In the first instance, our sense of dignity depends on recognition of our universal status as moral agents. Given our sense of dignity, we expect to be accorded the same rights and entitlements as other members of society. In the second instance, however, our sense of self-worth depends upon recognition of the value of our particular form of life (see also Honneth 1995: 92f.).

The demand for recognition of a distinct identity is sustained by the ideal of authenticity, that every individual or people has an original way of being in the world, which they should seek to realise (PA: 227-229). ${ }^{4}$ The value of identity is that it situates us in relation to an ultimate good. While our identity is partly constituted from without through relations of recognition, it is also partly worked out from within through selfinterpretation and articulation. An identity is, in this sense, 'something one ought to be true to, can fail to uphold, can surrender when one ought to' (SS:

\footnotetext{
${ }^{3}$ Taylor's communitarianism needs qualification since he describes his project as recovering the moral sources that empower our liberal presuppositions. Yet in doing so he advocates a 'holist' ontology that stands in contrast the 'atomist' prejudices that underlie much liberal philosophy (PA: 186).

4 'There is a certain way of being human that is my way. I am called upon to live my life in this way, and not in imitation of anyone else's life. But this notion gives a new importance to being true to myself. If I am not, I miss the point of my life; I miss what being human is for me' (PA: 228).
} 
30). An identity is of fundamental importance to being a human agent, since it defines the horizon within which we judge what has worth in our lives and what makes our life worthwhile (PP 1: 23; SS: 19). It provides the 'background against which our tastes and desires and aspirations make sense' (PA: 231).

By furnishing us with a vocabulary of worth, an identity makes us capable of 'strong evaluation' (PP 1: 15-44; SS: 27). As strong evaluators, we act and judge according to the 'kind of beings we are or want to be' (PP 1: 23). The capacity for strong evaluation is constitutive of human agency since it enables us to form second-order desires, to judge our immediate desires as higher or lower, noble or base (PP 1: 16). It is due to this trait that we attribute depth to human agents. Without the capacity for strong evaluation an individual would be a 'simple weigher of consequences' (PP 1: 23). Agency depends upon being able to positively identify with a particular form of life because we cannot act meaningfully without the orientation to the good that an identity provides. ${ }^{5}$ In its absence we are 'at sea', disoriented, without a sense of the worth of things (SS: 30). Just as Locke fears the boundlessness of conscience in politics, Taylor rejects the notion that all values ultimately depend upon the arbitrarily determined identity of the person who happens to hold them (PA: 254-256). Rather, authenticity presupposes a moral source that exists beyond the self, but which must be articulated in terms of the identity that orients us to it (SS: 510; EA: 41).

Our capacity for self-realisation, then, depends on our ability to articulate our personal vision of the good and interpret our moral experience in relation to it. We engage in self-interpretation and thus find meaning in our lives by telling a story of our self in terms of our quest for the good (SS: 47-52). ${ }^{6}$ Such a narrative provides a coherent framework for understanding

\footnotetext{
5 'To know who I am is a species of knowing where I stand. My identity is defined by the commitments and identifications which provide the frame or horizon within which I can try to determine from case to case what is good, or valuable, or what ought to be done, or what I endorse or oppose. In other words, it is the horizon within which I am capable of taking a stand' (SS: 27).

${ }^{6}$ While an identity orients us in moral space we must also be able to locate ourselves within this space. Human beings have a basic desire to be 'rightly placed in relation to the good' (SS: 44). Our sense of self-worth depends on how well we live up to our ideals, how near or far we perceive ourselves to be in relation to the good and whether we are directed toward or away from it (SS: 47).
} 
those events that have formed us, made us who we are today, got us to where we are. Moreover, our life-story projects where we are going, what we are questing for. Yet, this narrative is always open to revision. We revise our self-interpretations as we articulate more closely our conception of the good. More radically, we may discover the inadequacy of a previous conception of the good for making sense of and guiding us through moral dilemmas (PP1: 27). Hence we may replace it with some other, more adequate, notion of the good. In such cases we reinterpret our moral experience in terms of our orientation to this new good and, hence, develop a new narrative of our quest.

Taylor's metaphor of moral space is meant to capture the sense in which we find ourselves in a moral predicament, a context of moral questions that exist independently of our selves (SS: 41). The way in which these questions are posed to us and the responses available to us are significantly shaped by the particular culture in which we find ourselves (HMS: 87f.; RS: 45). We are capable of defining our identity, and hence becoming 'full human agents' only through our 'acquisition of rich human languages of expression' (PA: 230). Language is an 'irreducibly social good' in that its value does not depend only on individual utility but rather on its constitutive nature and common enjoyment. Language establishes the possibility of meaning and, hence, of judgement and action (PA: 136f.). Thoughts, feelings and values are only possible against the background of meanings that a language provides. Language thus exists between members of a community, containing their shared ways of being. Since its locus is a society, the value of language cannot be reduced to an aggregate of individual interests and sentiments. Language is an irreducibly social good in that an essential aspect of its being good is that it is enjoyed in common with others. It is not a collective good because many people happen to find it good, but they find it good because it is collectively enjoyed. A cultural identity is itself an irreducibly social good, then, since it is sustained by language and institutions. As such it has an inherent worth that makes a claim on the individual beyond her immediate desires and interests (PA: 230231).

Taylor's account of the dialogical character of the human condition leads him to a much richer understanding of human interdependence than is 
afforded by Locke's theory of the social contract. In social and political life we depend upon each other not only for our common security but to work out an identity that makes us capable of strong evaluation. An identity, then, is not something that can be set aside when we enter politics. Rather, our identities move us to moral and political action. ${ }^{7}$ A politics of recognition thus politicises the boundary between private and public on which an ethic of toleration rests. For those subaltern groups and minorities whose form of life have been denigrated and disrespected, recognition within the private sphere is insufficient to restore their sense of self-worth. Only public recognition will vindicate their claim to equal membership in the polity not despite their otherness but on the basis of it. Struggles for recognition thus foreground fundamental issues concerning the terms of political association.

However, the strong claim that due recognition is not just a courtesy we owe people but a vital human need relies on an ambiguous conception of identity as at once relational and essential or, in Taylor's terms, dialogical and monological. We need the recognition of others because we cannot form our identity in isolation but must realise it through social dialogue. Hence, we owe the other due recognition because we undermine the other's potential to flourish by misrecognising her. But the demand for recognition is also sustained by the ideal of authenticity, that I have an original way of being in the world to which I should be true. As Taylor points out, this ideal tends to posit identity as something that is more 'inwardly generated' than 'socially derived' (PA: 229). Although he recognises this contradiction, Taylor glosses over the essentialism inherent in the ethic of authenticity by arguing that its emergence reflects the fact that identities are no longer unproblematically ascribed according to one's social position. Instead, forming an identity is understood as part of an individual's life project. Identity can no longer be taken for granted but must be struggled for. Since, in modern societies, identities are 'formed in open dialogue, undefined by a

\footnotetext{
${ }^{7}$ As Taylor puts it, 'If we set aside everything that derives from identity and the troubles and conflicts related to it, the world would seem more simple and manageable. But I strongly doubt the realism of any project which consists in trying to convince our co-citizens to 'think of something else'. Those whose identity is solid will applaud you but this is because they are already thinking of something else. Those whose identity is precarious will see this as another way to not take them seriously' (in Taylor \& de Lara 1998: 108).
} 
social script', the politics of recognition has become more central and stressful (PA: 232). ${ }^{8}$

The denunciation of other-induced distortions depends for its moral force on an implied counter-identity, a true self-image that has been distorted by relations of power. Misrecognition is condemned not only because it reduces ethical judgement to a relation of domination but because it fails to see the other as she 'really' is. Thus the demand for recognition, which 'goes forward spearheaded...by a powerful sense of both historical and continuing grievance', tends to presuppose an essential identity that must be recovered and restored to its proper place (RS: 193). Consequently, as Bauman (2001: 145) observes, there is a 'fundamentalist streak' in the politics of recognition that is difficult to eradicate. So long as the demand for recognition is underpinned by the ideal of authenticity it will tend to presuppose an identity that is, in some sense, non-negotiable because essential.

\subsection{Struggle for recognition and fusion of horizons}

Taylor makes only passing reference to Hegel in his essay on the politics of recognition. Yet, this understatement makes Hegel all the more powerfully felt as Taylor's true point of departure. According to Axel Honneth (1995: 3163), the struggle for recognition was originally conceived by Hegel as an intersubjectivist reinterpretation of the struggle for self-preservation in the state of nature. ${ }^{9}$ An implicit consciousness of right is already present in the state of nature, according to Hegel, and it is this that is articulated and made explicit in the social contract (Honneth 1995: 17). The implicit awareness of right becomes apparent in the social meanings ascribed to the conflict that is

\footnotetext{
${ }^{8}$ Honneth (2001: 52-53) persuasively argues that Taylor's historical stylisations and simplifications lead to a misleading periodisation according to which a politics of identity has gradually displaced a politics of material interests and legal concerns. In turn this leads to a narrowing of the paradigm of recognition according to which issues for material distribution tend to be excluded from issues of social esteem.

${ }^{9}$ For Hegel, the problem with the atomistic conception of the state of nature is that it cannot provide grounds by which individuals arrive at an intersubjective understanding of their rights and duties. Rather, the determination of right must be imported from the outside: 'the act of making the contract is posited either as a demand of prudence (Hobbes) or as a postulate of morality (Kant, Fichte)' (Honneth 1995: 41).
} 
initiated when one agent imposes his will on another. ${ }^{10}$ The socially ignored individual retaliates to make the other take notice of him. He stakes his life in defence of his honour. His response, then, is not mere self-assertion arising from the primordial instinct of self-preservation, as Schmitt suggests.11 Rather, it expresses a normative expectation that he should be accorded positive consideration in the plans of others (Honneth 1995: 42-43).

In his later work, Hegel (1997: 111-119) presents the struggle for recognition not as an account of the emergence of political society but of selfconsciousness. Following Kojève's (1980: 3-30) influential reading of the dialectic of lordship and bondage, the emergence of self-consciousness is driven by desire. Human desire is the desire not simply to consume, but to be desired by, the other. Self-consciousness can only be realised intersubjectively since the self depends on the presence of another desiring consciousness to affirm its own self-image. The desire for recognition is thus the desire for the other to 'recognise my value for his value' (Kojève 1980: 7). The struggle for recognition is initiated by the attempts of each subject to win recognition from the other. Each seeks to impose its own reality, its 'particular sense of itself' on the other (H: 155). However, attempts to win recognition from the other by force ultimately fail. If the struggle for recognition is settled by a contest of strength, recognition is predicated on a relation of domination in which the subjectification of the lord is won at the cost of the objectification of the bondsman. This relation fails to satisfy the desire for recognition since the lord has won a recognition that is 'without value to him' (Kojève 1980: 17). By withholding recognition of the other, the lord has denied in the other that quality of selfhood that led him to seek recognition in the first place. The recognition of the bondsman is not valued

\footnotetext{
${ }^{10}$ Honneth (1995: 42) characterises Hegel's line of thought as follows: 'in order to show, as against the dominant intellectual tradition, that subjects, can, on their own, reach a conflict resolution based on law (as formulated in the social contract) even under conditions of hostile competition, theoretical attention must be shifted to the intersubjective social relations that always already guarantee a minimal normative consensus in advance; for it is only in these pre-contractual relations of mutual recognition - which underlie even relations of social competition - that the moral potential evidenced in individuals' willingness to reciprocally restrict their own spheres of liberty can be anchored.'

11 'The enemy is a negated otherness. But this negation is mutual and this mutuality of negations has its own concrete existence, as a relation between enemies; this relation of two nothingness on both sides bears the dangers of war' (CP: 63).
} 
since his status as an equal and independent subject has been denied (PA: 241). 12

According to Kojève's political rendition of the dialectic of lordship and bondage, it is from the unequal conditions of a society divided into masters and slaves that progressive social relations must emerge. Importantly, the dynamic for progressive social change is inherent in the struggle for recognition since genuine recognition can only be realised through the reconciliation of master and slave in a state of absolute reciprocity, a "we' that is an ' $\mathrm{I}$ ' and an ' $\mathrm{I}$ ' that is a 'we" (Hegel quoted in PA: 241; H: 148). On this account, social conflict is conceived as a 'moral force within lived social reality' that propels the development of ethical relations and social integration (Honneth 1995: 143).13 Within a given polity, justificatory norms give rise to expectations concerning the forms of respect one is entitled to as a member of that community. When such demands are met this leads to an expansion and deepening of the relations of recognition in society. It leads toward a higher stage of ethical relations, a more inclusive society in which 'undistorted forms of recognition' are realised (Honneth 1995: 170).

Following Gadamer, Taylor explains how such deepening of relations of recognition might come about in terms of a hermeneutic dialogue oriented toward a 'fusion of horizons' (PA: 252). In contrast to Lockean toleration, recognition does not require suspending or stepping back from our prejudices. Rather, our prejudices provide a resource for judgement because they furnish us with a vocabulary of worth. Taylor rejects the feasibility of the natural science model that underpins Locke's philosophy, according to which misrecognition is overcome by finding a universal and value-free

\footnotetext{
12 'The relation between Master and Slave...is not recognition properly so-called...The Master is not the only one to consider himself Master. The Slave, also, considers him as such. Hence, he is recognised in his human reality and dignity. But this recognition is one-sided, for he does not recognise in turn the Slave's human reality and dignity. Hence, he is recognised by someone whom he does not recognise. And this is what is insufficient - what is tragic - in his situation...For he can be satisfied only by recognition from one whom he recognises as worthy of recognising him' (Kojève 1980: 19).

13 '...conflict represents a sort of mechanism of social integration into community, which forces subjects to recognise each other mutually in such a way that their individual consciousness of totality has ultimately become interwoven, together with that of everyone else, into a 'universal' consciousness' (Honneth 1995: 28).
} 
point of view (see 2.2). Such an aspiration is misguided since it is impossible to step outside of our own cultural milieu (PP2: 123f.). Moreover, it makes us inarticulate about our own conception of the good so that we remain unaware of how it shapes our judgements (SS: 53-90). Consequently, we risk mistaking our particular understanding for universal truth (PA: 237).

Similarly untenable is the 'incorrigibility thesis' associated with a pessimistic, 'neo-Nietzschean' account of the recognition relation (PP2: 125f.). Since all judgements of worth are taken to be 'based on standards that are ultimately imposed by and further entrench structures of power', the only way to avoid ethnocentrism, on this view, is to accept uncritically the selfinterpretations of the other (PA: 254). For Taylor, however, this is no kind of understanding at all since there is no mediation between interpretative frameworks. The slide to subjectivism curtails the possibility of any genuine intersubjective understanding. Since there is only 'our' language or 'their' language, no judgement of comparative worth is possible. The incorrigibility thesis is thus inadequate in the face of the other who wants us to recognise her value as our value. Far from granting due recognition, providing a 'favourable judgement on demand' can only amount to an 'act of breathtaking condescension' (PA: 254-255).

According to Taylor, misrecognition comes about not so much because of our prejudices but by our failure to adequately articulate them and to take those of the other seriously. Ethnocentrism means unreflectively judging the other in terms of our own vocabulary of worth (PA: 152; PP2: 126f.). What is offensive about such judgements is that they fail to take sufficient account of the self-understandings of the culture in question. Moreover, in doing so they find these other cultures to be inferior. The other is found to be a transgressor of our own values rather than recognised as possessing her own conception of the good. In order to avoid ethnocentrism, then, we must make a presumption of equal worth when entering into the dialogical encounter that is required for recognition (PA: 256). A genuine attempt at understanding presumes that the other's form of life has something valuable to say to us, that in coming to an understanding of the other we may discover some inadequacy in our own conception of the good. While there may be aspects of the other's form of life that we eventually choose to reject, it is almost certain that there will be aspects of it that are 
worthy of our admiration and respect. Putting the point negatively, Taylor suggests that 'it would take supreme arrogance to discount this possibility $a$ priori' (Taylor 1995: 256).

Genuine recognition is oriented 'toward a wider understanding which can englobe the other undistortively' and thus allows for real judgements of worth to be made (PA: 151). In the first instance, this requires comprehending the other in such a way that we are able to apply 'the desirability characterisations which define his world' (PA: 119). This means being able to articulate the vocabulary of worth through which he makes strong evaluations. In seeking to understand the other in his own terms, however, it is no more possible to step entirely inside the other's horizon than it is to step outside all horizons entirely. Rather, recognition must be mediated by our own self-understandings. In this way we enter into a dialogue with the other that requires us to more carefully articulate our own self-understandings through which this dialogue is mediated. By reflecting on our practices in relation to those of the other, we are forced to articulate our background assumptions, to make explicit what was formerly implicit. Through this dialectical process of re-cognition and re-articulation we should arrive at a more open sense of human possibilities. What we formerly took to be an inescapable limit to human experience - 'the way we do things around here' - becomes felt as one possibility among others (PA: 149).

In coming to an undistorted recognition of the other, therefore, we do not simply re-present her in our own terms but rather within a 'language of perspicuous contrast'. Such a language should enable us to 'formulate both their way of life and ours as alternative possibilities in relation to some human constants at work in both' (PP2: 125). We know we have developed such a language when both partners to the dialogue could accept the points of contrast and comparison stated between the two frameworks. It is only once we have developed this language of perspicuous contrast that we have arrived at a shared horizon in which non-distortive recognition is possible. In doing so, we no longer perceive the other only as a 'transgressor of our limits'. Rather, we are able to perceive 'two goods where before we could only see one and its negation' (PA: 162-163). 
For Taylor, then, a particular identity is not valuable simply because it is the identity an individual happens to have. That an identity has previously been denigrated does not qualify it for recognition of equal worth. Rather, we must be able to judge the value of particular identities in terms of their capacity to draw us closer to the good. Moreover, our own identity must remain open to re-articulation and revision. The fusion of horizons is an ongoing process rather than a stable endpoint. Because our selfunderstandings are constantly changing as we rearticulate our conception of the good, so too is the horizon within which we recognise the other shifting. Yet, the process of recognition and rearticulation has value in itself since it is through our dialogical relations with others that we enrich our vocabulary of worth and hence draw closer to our own moral sources (SS: 92). Overcoming distorted relations of recognition requires that we enter an open-ended dialogue with the other that holds out the possibility of coming to a shared understanding through the constant widening of our partial and necessarily limited cultural horizons.

As such, there is a risk inherent in the politics of recognition. By seeking to arrive at a non-distortive recognition of the other, our own prejudices and standards of judgement will almost certainly be transformed. As Fives (2001: 207) puts it, recognition requires that we 'put the presuppositions of our criteria at risk in the attempt to take seriously the potential truth of their utterances and cultural products.' Not only our selfinterpretations and the frameworks within which we make strong evaluations are risked, however, but also the terms in which recognition is construed. In order to get the struggle for recognition off the ground we must presuppose limits that define identity and otherness, the boundaries that separate self and other, us and them. These distinctions are necessary in order to open the possibility of an advance on our own partiality, which is brought about through a mutual openness to learn from each other. Yet, our encounter with the other and the situation in which it takes place may lead us to question and re-articulate the terms within which this encounter is initially framed.

While Taylor invites the first risk (of transforming self-understandings through the struggle for recognition), however, he wants to avoid the second (that the terms of the recognition-relation itself might be similarly 
transformed). As Fives (2001: 205) discusses, Taylor departs from Gadamer in representing the horizon in which undistorted recognition is arrived at as 'shared' rather than 'fused'. Within this shared horizon the constitutive identities of self and other remain as equally valid, but mutually discreet, bases for judgement. The 'we' that is constituted by this shared horizon thus serves to preserve the authentic identities that originated the struggle for recognition. A tension thus emerges between the origin and end of action. Given the irreducibly social good of identity, Taylor wants to set the terms of recognition in advance. While allowing that our identities may be transformed through our inter-action, he wants to preserve the boundary that defines one authentic identity as distinct from another. ${ }^{14}$ An ethic of recognition wants to avoid the risk of the politics by privileging the survival of the 'defining community' (SS: 36). Ironically, however, there is a danger that setting the terms of recognition beyond politics serves to entrench the relation of enmity that we hoped to transform through recognition.

\subsection{The anti-political moment of recognition}

Taylor's optimism about the possibility of a fusion of horizons depends on the assumption that recognition is distorted by relations of power. We reach an undistorted recognition when we relinquish force as a means of imposing our truth on the other and the ethical impetus to overcome the distortions of power is inherent in the struggle for recognition itself. Against Hegel, however, much twentieth century philosophy has found the recognition relation itself to be 'necessarily complicit with a logic of violent appropriation' (Yar 2001: 57). As Majid Yar discusses, Sartre, Levinas and the French tradition of 'post'-theories they have influenced, represent recognition as specular rather than dialogical (see also Honneth 1995: 156159; Williams 1992: 290-301). Sartre and Levinas draw attention to the antipolitical moment of recognition that is present in the objectifying 'gaze' that

\footnotetext{
${ }^{14}$ Taylor thus seems to forget Gadamer's (1986: 271) insight that: 'Just as the individual is never simply an individual, because he is always involved with others, so too the closed horizon that is supposed to enclose a culture is an abstraction. The historical movement of human life consists in the fact that it is never utterly bound to any one standpoint, and hence can never have a truly closed horizon. The horizon is, rather, something into which we move and that moves with us.'
} 
reifies the other. ${ }^{15}$ The knowing look of recognition over-determines the other and so constitutes the death of her possibilities. To render the other 'known, understood, interpretable, is to rob her of her alterity or difference, to appropriate and assimilate her into a sameness with my own subjectivity' (Yar 2001: 62). ${ }^{16}$ Since knowledge is taken to be necessarily implicated in relations of power, Hegelian teleology is rejected. On this view, history 'does not gradually progress from combat to combat until it arrives at mutual reciprocity'. Rather, it 'proceeds from domination to domination' (Foucault 1984: 85; see also Lyotard 1984: 15-17).

Fanon's analysis of the colonial situation is significantly influenced by Sartre. In his philosophical writing, Sartre presents a profoundly pessimistic account of intersubjectivity that precludes any role for recognition as a way to realise society. While subjects depend on the recognition of others to achieve self-consciousness, being the object of the other's look is experienced as a 'profound violation' (Yar 2001: 60). Recognition at once constitutes the individual's being and robs her of her being by limiting her possibilities for self-creation. Crucially, it is not possible to be both subject and object of such a look: one is either the seeing-subject or the object-seen. The only way to overcome one's objectification by the seeing-subject is to turn the tables on the other, to 'make her into the object of my own look, thereby depriving her of her own freedom via my definitional, judging act, and so reclaiming my own' (Yar 2001: 60). As such, 'conflict is the original meaning of being-forothers' (Sartre in Yar 2001: 61). Intersubjective life is characterised by a perpetual, antagonistic struggle of mutual objectification. Since recognition is always predicated on the subject-object relation, which is synonymous with the relation of dominant to subordinate, the recognition-relation is not understood to be 'distorted' by power. Rather, recognition is contiguous with the deployment of power.

\footnotetext{
${ }^{15}$ While for Schmitt this might constitute the affirmative, existential moment of the political as the recognition of the true enemy, I want to call this moment anti-political, in a normative sense, because it entails a reduction of experience or meaning that exceeds the terms of identity and otherness. If the political refers us to the opening up of possibilities, this tendency to closure and reduction can be understood as anti-political.

${ }^{16}$ Thus, Edward Said argues that, in making the other an object of knowledge, Orientalism turns the Orient into an immutable 'fact' which resists revision. 'To have knowledge of such a thing is to dominate it' (Said 1978: 32).
} 
Fanon (1986: 109f.) vividly describes the experience of violation in the anti-political moment in which he is recognised by a white child in the streets of Paris: 'Look, a Negro'. Rather, than being free to make a meaning for himself, he encounters a meaning that is always 'already there, pre-existing, waiting' for him (Fanon 1986: 134). Since this meaning is inscribed in the colour of his skin, his 'appearance saps, invalidates all his actions' (Fanon 1986: 214). Moreover, he is unable to turn the tables, to return the gaze of the coloniser. He has 'no ontological resistance' to the colonising gaze (Fanon 1986: 110; see also Memmi 1990: 151; Said 1978: 230). When he seeks recognition of his common humanity he is fixed by 'the movements, the attitudes, the glances of the other' just as a 'chemical solution is fixed by a dye' (Fanon 1986: 109). When he seeks recognition of his difference, he is either 'battered down by tom-toms, cannibalism, intellectual deficiency' or romanticised, equated with 'emotion, childishness, life, innocence, spontaneity' (Fanon 1986: 112, 132). Since colonial identities are constituted through relations of power, Fanon is pessimistic both about the possibility of black authenticity in a white world and of a fusion of horizons between African and European (Fanon 1986: 93; Macey 1999: 11).

Following Sartre's portrait of anti-Semite and Jew, Memmi describes the dilemma of authenticity in the colonial situation. ${ }^{17}$ The colonised may seek liberation by proving himself equal to the coloniser in terms of the values of the colonising culture. But assimilation entails self-negation. In adopting the values of the coloniser, the colonised 'adopts his own condemnation' (Memmi 1990: 187). For his inferiority is embedded in the coloniser's vocabulary of worth. Since assimilation is untenable, his only option is to 'shake off' the 'accusing and annihilating image' imposed on him by the coloniser (Memmi 1990: 194). The colonised reverses the colonialist accusation by positively re-evaluating his denigrated form of life. Instead of trying to measure up to the colonisers according to the norms of the colonising culture, he seeks to recover indigenous values in his neglected traditions, language, history and religion. The colonised must rebuild their

\footnotetext{
17 According to Sartre, authenticity does not involve being true to one's self but, rather, being true to one's situation by one's choice of self. While our situation forms us and decides our possibilities, we are free to give meaning to our situation by the choices we make 'within it and by it' (Sartre 1970: 60). Consequently, authenticity 'consists in having a true and lucid consciousness of the situation, in assuming the responsibilities and risks that it involves, in accepting it in pride or humiliation, sometimes in horror or hate' (Sartre 1970: 90).
} 
'authentic nature...reform their unity, communicate with it and feel that they belong' (Memmi 1990: 201). Yet, the process of self-recovery is problematic. For 'in the midst of revolt' the colonised accept their difference and separation from the colonisers and so continue to define their world in terms of the colonial situation, 'to think, feel and live against and, therefore, in relation to the coloniser' (Memmi 1990: 205).

True liberation thus requires overcoming the terms of colonialism itself, which constitute the identities of coloniser and colonised, friend and enemy, in radical opposition to each other (Memmi 1990: 217-219). ${ }^{18}$ In this context, Sartre (1963: 60) describes 'Negritude' as a moment of negativity. The cultural recovery and assertion of an African identity is a stage in a dialectical process in which the colonised reclaim their full humanity. Sartre likens the quest for Negritude to Orpheus's journey to Hades to recover his dead wife, Eurydice. Orpheus is told that he can have Eurydice back so long as he does not turn to see her follow; when he does she vanishes. Like Orpheus, at the moment the colonised embraces his lost identity it vanishes between his arms. Fanon is similarly aware of the contradictions of black authenticity. Those who want to create a black culture, he argues, 'forget that niggers are disappearing, just as those people who brought them into being are seeing the break-up of their economic and cultural superiority' (Fanon 1965: 188-189). The search for a black identity is fraught with difficulties since 'what is often called the black soul is a white man's artefact' (Fanon 1986: 16).

Yet Fanon responds indignantly to Sartre's image of black Orpheus, accusing him of a further reduction. Fanon agrees that the self-assertion of a stigmatised identity entails a reactive politics. However, Sartre betrays the condescending attitude of the colonising culture in explaining Negritude as a transitional moment. In doing so, Sartre robs the colonised of their authenticity, ruptures their lived experience, destroys the vitality of the moment of self-assertion. ${ }^{19}$ For Fanon, Negritude is at 'at once untenable and

\footnotetext{
18 'The struggle for freedom does not give back to the national culture its former value and shape; this struggle which aims at a fundamentally different set of relations between men cannot leave intact either the form or the content of the people's culture. After the conflict there is not only the disappearance of colonialism but also the disappearance of the colonised man' (Fanon 1965: 197).

19 'I wanted to be typically Negro - it was no longer possible. I wanted to be white - that was a joke. And, when I tried, on the level of ideas and intellectual activity, to reclaim my
} 
yet necessary' (Kruks 1996: 130). It is necessary in order to establish a solidarity among the oppressed that can form the basis for collective action. But it is an untenable identity by which to lead one's life because it is too restrictive: 'My black skin is not the wrapping of specific values...In the world through which in travel, I am endlessly creating myself' (Fanon 1986: 227). Just as the search for a black identity in the wake of oppression is fraught with difficulties, so the recognition offered by the former oppressor remains implicated in relations of power, no matter how well-intentioned his efforts may be. While we desire the recognition of the other, there is a sense in which recognition is always anti-political for it always robs us of our possibilities for self creation.

Fanon is pessimistic not only about the possibility of being true to an authentic origin but the possibility that the struggle for recognition will end at a fusion of horizons. For he suspects that far from desiring recognition, the settler looks on the native with indifference (Fanon 1986: 220; see also van Roermund 2001: 189). According to Fanon, there is no 'absolute reciprocity' in the colonial situation. Rather, the relation of settler and native is defined by 'reciprocal exclusivity'. The zones of settler and native, though opposed, are 'not in the service of some higher unity' (Fanon 1965: 31-32). Mutual recognition is impossible because the native is not complimentary but superfluous to the settler. As such, there is no intersubjective struggle (Fanon 1986: 220). In 'closing the circuit' of reciprocal recognition the coloniser 'keeps the other within himself', seals him into 'thingness' (Fanon 1986: 217, 218). Consequently, the liberation of the slave depends not on recognition from the master but his death or exile (Fanon 1965: 33). ${ }^{20}$

I doubt that a class of oppressors can ever be wholly independent from and indifferent to those they oppress. Memmi shows this clearly when he argues that, in his situation as privileged usurper, the coloniser can choose

negritude, it was snatched away form me...Nothing is more unwelcome than the commonplace: "You'll change, my boy; I was like that too when I was young...you'll see, it will all pass." (Fanon 1986: 132-135)

20 'When it does happen that the Negro looks fiercely at the white man, the white man tells him: "Brother, there is no difference between us." And yet the Negro knows that there is a difference. He wants it. He wants the white to turn on him and shout: "Damn nigger." Then he would have that unique chance - to "show them..." But most often there is nothing nothing but indifference, or a paternalistic curiosity. The former slave needs a challenge to his humanity, he wants a conflict, a riot. But it is too late' (Fanon 1986: 221). 
only between uneasiness and evil (Memmi 1990: 109). ${ }^{21}$ However, Fanon's suspicion of the indifference of the coloniser warns against what Emilios Christodoulidis (2000: 190-196) aptly calls an 'unwarranted assumption of a "we". As we have seen, an optimistic understanding of the politics of recognition presumes that it is impelled by a 'moral potential that is structurally inherent in communicative relations between subjects' (Honneth 1995: 67). Yet such an assumption may be unfounded. Conflict does have an integrative effect; it defines social identities in important ways. However, conflict can be either communal or non-communal.22 Both forms of conflict enhance community but each 'sets its constituency differently' (Christodoulidis 2000: 191). As Christodoulidis (2000: 192) points out, the risk of politics is that conflict may be of the non-communal sort that drives communities apart rather than the communal sort that brings people closer together.

If by taking identity as the authentic origin of action a politics of recognition risks entrenching a relation of enmity, by presupposing that conflict will end in a fusion of horizons it elides the risk that enmity might endure. This paradox - that a politics of recognition both reifies opposing identities and presumes identity as the outcome of their conflict - arises due to the ambiguous conception of identity on which it relies (as we saw in 3.1). To criticise an ethic of recognition for doing both is to state the same point from opposite directions, namely, that the risk of politics cannot be mitigated by determining in advance the terms of association and dissociation. Rather, the terms of recognition must also be risked in seeking to overcome a relation of enmity. As Christodoulidis (2000: 196) argues, a politics of recognition must acknowledge the contingency and revisability of who "we" are.

\footnotetext{
${ }^{21}$ In refusing colonialism, he lives the contradiction of renouncing its values while benefiting from its privileges. Yet in accepting colonialism, he accepts himself as a 'nonlegitimate privileged person...a usurper' and thus accepts the 'blame implied by that role' (Memmi 1990: 118, 117). In seeking to legitimate his position he is driven to demonstrate his superiority further and so only depeens his guilt.

${ }^{22}$ Christodoulidis (2000: 192) quotes Simmel: 'Non-communal conflict results when there is no community of ends between the parties to the conflict...Non-communal conflict is seen as disruptive and dissociating. Communal conflict, that is based on a common acceptance of basic ends, is, on the contrary, integrative. When men settle their differences on the basis of unity, communal conflict will ensue.' Christodoulidis goes on to note that: 'Talk of reconciliation all too often elides the distinction that matters by disposing of the dangerous non-communal type of conflict and assuming that conflict is always-already of the communal type.'
} 


\subsection{The dilemma of recognition}

Recognition opens the possibility of political reconciliation by taking the struggle over identity, the question of who 'we' are as the basis for the realisation of society between friend and enemy. Recognition moves beyond the limit of toleration, then, but it also leads to a dilemma. The desire for recognition provides the basis for an ethical and integrative conflict that holds out the possibility of constituting a horizon of understanding that might enclose former enemies without distortion. However, the anti-political moment of recognition constantly threatens to close off the possibility of reconciliation by over-determining self and other in terms of an authentic identity. Recognition thus appears both a necessary and untenable basis for political reconciliation. In order to initiate reconciliation between former enemies a politics of recognition must be predicated within the terms of identity and otherness according to which past wrongs were perpetrated. Yet, to the extent that such a politics takes these identities as irreducibly social goods, it risks entrenching and reifying those terms that political reconciliation ought to call into question.

The anti-political moment of recognition becomes particularly apparent when recognition is institutionalised for the sake of cultural survival. In contrast to the principle of non-interference that Lockean toleration imposes on a liberal regime, an ethic of recognition may require the state to ensure the survival and flourishing of a particular form of life (Taylor 1995: 246). In Taylor's view, recognition enjoins us to accept cultural survivance as a legitimate collective goal, even though this may compromise non-fundamental individual freedoms or rights. What distinguishes survivance policies in particular is that they 'actively seek to create members of the community' (PA: 246). To ensure cultural survival, it is not enough, for instance, that the language of a cultural group is preserved so that it remains as a resource available to individuals. Rather, a policy aimed at survival would need to ensure that future generations of a particular ethnic group continue to identify as speakers of that language (PA: 246). I agree with Taylor that such policies are not easily reconcilable with a procedural liberalism that is 'inhospitable to difference' because it insists on uniform application of rights and is suspicious of collective goals (PA: 248). 
However, Taylor's optimism about the possibility of establishing a regime of reciprocal recognition makes him insensitive to the anti-political moment of recognition and, in particular, the possibility of a repressive authenticity. Several of Taylor's critics point to the potential for authoritarianism inherent in a principle of cultural survivance that takes a particular cultural identity as an irreducibly social good. Iris Marion Young (1997: 387-388), for instance, points out that policies that actively seek to create future members of the community threaten to freeze social relations by establishing rigid inside-outside distinctions. Moreover, they may impose unwelcome 'life-scripts' on individual group members, they imply that members of a group have common interests and they tend to ignore differences within and across groups (see also Fraser 2001: 24). Similarly, Jürgen Habermas (1994: 128f.) argues that cultural reproduction should only be enabled, not guaranteed, by the state. For in guaranteeing cultural survival the state deprives community members of 'the very freedom to say yes or no that is necessary if they are to appropriate and preserve their cultural heritage' (Habermas 1994: 131; see also Weinstock 1994: 183). In short, the principle of cultural survivance is in danger of leading to the kind of misrecognition Taylor wants to avoid. By scripting an identity too tightly, a policy of cultural survivance may replace one form of tyranny with another. It may force members of a group into a social role with which they may not identify or which they may want to identify with only in certain contexts (Appiah 1994: 163).

These are pertinent, if well-worn, points of criticism as articulated within the terms of the liberal-communitarian debate. Yet they fail to capture the full sense in which the anti-political moment of recognition entails a logic of violent appropriation. This becomes more apparent when we shift our attention, as Linda Nicholson (1996: 2) suggests we should, from whether cultural survival compromises individual rights to the terms within which the cultural survival of a subaltern group may be recognised as legitimate by a dominant society. Elizabeth Povinelli (1998: 4), for instance, discusses the 'cunning of legal recognition of indigenous traditions in late modern liberal Australia'. In the 1990s, the High Court of Australia found that the principle of terra nullius, by which the dispossession of the land of indigenous peoples had hitherto been legally justified, did not apply. This opened the way for recognition of 'native title' within the common law of Australia as a 
legitimate basis for land-claims by indigenous peoples. ${ }^{23}$ At the time, the decisions of the High Court were widely praised for contributing to reconciliation through the widening and deepening of recognition between the settler society and indigenous Australians.

In fact, the Mabo (No.2) judgment demonstrates the dilemma of recognition. For as Valerie Kerruish and Jeannine Purdy (1998: 159) discuss, the belated legal recognition of aboriginal property in Australian law also provided the 'legal means and justification for its extinguishment by a sovereign power.' Whereas Australian common law derives its authority and content from the juridical traditions of the United Kingdom, native title is supposed to derive its authority and content from the customary laws by which aboriginal peoples lived prior to colonisation. With the rejection of terra nullius, the High Court found that native title might survive where it has not been washed away by the 'tide of history.' Native title is extinguished either by the recognition of freehold property rights or by the loss of those cultural institutions and practices that establish a group's connection to a region of land.

Yet recognition of 'native title' could not amount to recognition of aboriginal customary law as such but only insofar as it could be represented in terms commensurate with Australian common law. Consequently, aboriginal law is not recognised 'as law but as fact - to be proved as to its existence and content by evidence' (Kerruish \& Purdy 1998: 153). In this context, 'native title' is a legal fiction, retrospectively read back in to the history of common law to redeem common law from its complicity in the dispossession of indigenous Australians of their land. Whereas to indigenous Australians there was never any doubt that this dispossession amounted to theft, the common law could not recognise it as such without undermining its own legitimacy. Thus, the common law's belated recognition of indigenous peoples was only possible by substituting one legal fiction for another; namely, that native title did, in fact, exist at the time of settlement (even though it was not known to exist at that time) and that it continues to exist except where it has been intentionally extinguished by the sovereign that is, almost everywhere.

${ }^{23}$ Eddie Mabo v. the State of Queensland (1991) 107 ALR 82; The Wik Peoples v. the State of Queensland (1996) 141 ALR 129. 
With its partial rejection of terra nullius, the judgement thus made the legal identity of 'native title claimant/holder' available to Aboriginal peoples within Australian property law (Kerruish \& Purdy 1998: 152). ${ }^{24}$ But this was an identity that could only be claimed within the terms dictated by the common law. As Povinelli (1998) discusses, this meant that an impossible demand for authenticity was made of indigenous peoples in order for them to be recognised as 'native' by common law. A successful claim to native title depended on showing 'real acknowledgement of traditional law and real observance of traditional customs' (Povinelli 1998: 23). In order to be recognised, therefore, indigenous peoples are required to 'transport to the present ancient pre-national meanings and practices in whatever language and moral framework prevails at the time of enunciation' (Povinelli 1998: 23).

In this way, the colonial logic of cultural appropriation continues into the postcolonial legal-politics of reconciliation. Whereas, from the perspective of common law, recognition of native title appears as a deepening and widening of relations of social recognition, from the perspective of aboriginal customary law it appears as violent appropriation. Whereas, in the terms established by the colonial relationship, the 'true being of native title resides in an unknowable past ideal form, the true being of common law resides in an unknowable future formal ideal' (Povinelli 1998: 26 - emphasis added). The story of the common law is one of ethical progress as true justice is gradually realised through the deepening and widening of recognition. Common law is articulated through its particular judgements such as the jettisoning of terra nullius as a mistaken legal prejudice of the past - that draw us closer to the good of justice. By contrast, the story of Aboriginal customary law - recognised belatedly by the colonising culture is one of decline and (imperfect) recovery. In order to be recognised in the present, indigenous people must recover those traditions and customs that have not yet been washed away by the tide of history. Thus 'real' Aboriginal being depends on showing that one has been relatively untouched by history. Recognition of native title thus has the perverse consequence 'that those aboriginal peoples who do not satisfy the requirements of being

\footnotetext{
24 The doctrine of terra nullius was set aside for the purposes of land ownership but not of either sovereignty or jurisdiction (Kerruish \& Purdy 1998: 147).
} 
"native" continue to be unidentified inhabitants of a terra nullius' (Kerruish \& Purdy 1998: 153).

If the recognition-relation thus stands indicted for an inevitable complicity in the violent appropriation of the other, however, to dispense with recognition entirely is to give way to a form of indifference to the other. Though Fanon and Memmi stress the need to transcend the terms of self and other - coloniser and colonised - in which the recognition relation is predicated, they nevertheless stress the importance of reasserting a stigmatised identity. In seeking to affirm that difference or 'non-identity' that exceeds the reduction imposed by recognition - the 'open-door of every consciousness' as Fanon (1986: 232) puts it - there is a temptation to 'leap into a radical negativity' that eschews the terms of identity and otherness entirely (Dallmayr 1997: 38). Fred Dallmayr (1997: 34) argues that the aspiration among postmodern thinkers to affirm non-identity (or difference) sometimes slides into a celebration of 'non-distinction (or no-identity)' that can take the form of 'intellectual nomadism or an indifferent cosmopolitanism'. It is such indifference that Fanon objects to in Sartre's account of black Orpheus who finds that his 'true' identity vanishes as he embraces it. For, Fanon (1984: 135) insists, 'I am not a potentiality of something, I am wholly what I am...My Negro consciousness does not hold itself out as a lack. It is. It is its own follower.' Sartre's reduction of the moment of self-assertion to a stage in the dialectal transcendence of identity does violence to the lived experience of the colonised.

The dilemma of recognition, then, is that it seems to present us with a stark choice between reduction or indifference. As such, it appears both untenable and yet necessary. In order to overcome our perception of the other as enemy - the transgressor of our values - we must seek to 'understand him as he really is' (Memmi 1986: 149; Said 1978: 104). Yet positing the 'real' being of the other leads to a certain anti-political moment; the closing of the other's horizons within the terms of recognition. However, to eschew the terms of recognition entirely is to become indifferent to the other's form of life. For, as Dallmayr (1997: 34) asks: 'how could one honour the other's non-identity in the absence of a recognition of the distinctness and differential relation of self and other?' Though recognition necessarily entails 
a reduction, this reduction appears necessary in order to engage seriously with what is different in the other (see Feldman 1999: 24; Kruks 1996: 132).

Political reconciliation, then, must forestall the anti-political moment of recognition. While it cannot but proceed from the terms of self and other that constitute the interpretative horizons of those divided by past wrongs, it should also instantiate 'a reflective openness indefinitely postponing the moment of positive-affirmative closure' (Dallmayr 1997: 36). In recognising the identity of the other we would also seek to affirm her non-identity. Following Adorno, Dallmayr (1997: 35) defines non-identity as the 'surplus or excess of being over knowing, especially the excess of social and historical reality over the appropriating grasp of conceptualisation'. To affirm nonidentity is to allow ambiguity to unsettle those oppositional terms by which we make sense of the world. Acknowledgement of non-identity in this way provides a basis from which to call into question the terms of friend and enemy by which we recognise each other in politics. ${ }^{25}$

Political reconciliation, on this account, would entail overcoming enmity by holding to the faith that a relation of antagonism might turn out to be ethical and integrative. This faith in reconciliation opens the possibility of a politics through which a shared understanding might be arrived at. Yet the faith that a conflict may lead to the constitution of a shared horizon - one which might encompass former enemies non-distortively - cannot alleviate the risk of politics. Reconciliation needs what Michael Ignatieff (1996) calls 'articles of faith.' Yet, as Christodoulidis (2000: 196) insists, these 'need to be kept in view for being just that' because there is 'nothing ineluctable' about reconciliation leading to community. The risk for political reconciliation, then, is that 'it must remain attentive to [the] contingency and revisability of the 'we" it seeks to realise; 'it cannot police the risk by arbitrating memories and identities and fixing constituencies for communities' (Christodoulidis 2000: 196).

Although a politics of recognition invites the risk of politics - and, hence, the possibility of establishing society between former enemies - it

\footnotetext{
${ }^{25}$ Consequently, for Adorno, 'reconciliation...means the emancipation of non-identity, its release from the constraints of systematising rationality, and hence, the "surging forth of the multiplicity of differences"' (Dallmayr 1997: 39).
} 
tends to elide this risk by presuming community rather than acknowledging this as the contingent outcome of interaction. For Hannah Arendt, by contrast, the possibility of constituting a "we" depends not so much on recognising the what of each other's identity but on disclosing who "we" are through collective action. As I will show in the following chapter, Arendt's ethic of worldliness thus provides the basis for a political conception of reconciliation that, in Christodoulidis's terms, accepts the risk of politics while aspiring to the faith of reconciliation. 


\section{Worldliness}

For reconciliation to be political, I argued in chapter one, it cannot presuppose community or a common moral law that is known by all. Rather it must attend to the risk of politics, which, following Schmitt, we understood as the ever-present possibility of the friend-enemy relation. In chapter two, we saw that toleration helps to delimit a space for a reconciliatory politics by limiting the end of politics to the public good of security. However, the exclusion of substantive moral doctrines as legitimate grounds for political action unduly limits the terms within which such a reconciliatory politics might be enacted. Consequently, it prevents antagonists from discovering good reasons to live together in the first place. We saw, in chapter three, that recognition shows a way beyond this limit of toleration by recasting antagonism as a reciprocal dialogue oriented to a common understanding. Such a struggle for recognition appears necessary in order to initiate political reconciliation. Yet it also leads to a dilemma in which, it seems, we must choose between appropriation of or indifference to the identity of the other.

In this chapter, I develop Hannah Arendt's ethic of worldliness in contrast to toleration and recognition and show how it provides a more adequate basis for developing a political conception of reconciliation. Like Schmitt, Arendt understands the political to be autonomous from the moral and looks to politics to affirm the seriousness of life. However, against Schmitt's reductive account of the political as being against others, she emphasises the world-disclosing potential of politics that arises out of being with others. An ethic of worldliness overcomes the limit of toleration since it understands the public good of political association to be not only security but an organised remembrance that redeems human affairs from the futility of our acting and suffering in the world. Moreover, worldliness avoids the dilemma of recognition since it conceptualises community neither in terms of 
an original identity to which we should be true nor an inevitable end of social conflict but as the contingent and fragile achievement of political interaction.

In 4.1, I show how Arendt affirms the world-disclosing potential of politics against the world-curtailing negation of human freedom perpetrated by totalitarian regimes. In 4.2 I argue that the world-disclosing potential of politics presupposes both the promise and risk of action. The political thus entails an unceasing effort to reconcile the boundless potentialities of action with the limits and frailties of the world. In 4.3 I show how Arendt's theory of political judgement as reflective, extends and completes her account of action as performance enacted with the space of appearances. This chapter therefore provides the basis for a preliminary account of political reconciliation as an open-ended interaction through which former enemies seek to delimit the commonness of the world that lies between them while affirming each other's freedom to call this world into question.

\subsection{The world disclosing potential of politics}

Hannah Arendt articulates her political ethic of worldliness against the emergence of totalitarianism as an unprecedented form of rule. For Arendt, totalitarianism cannot be properly understood in terms of the juridical political morality expounded by Locke. According to Locke, as we saw in 2.3, tyranny comes about when the sovereign 'makes not the Law, but his Will, the Rule' (T: 2.199). Yet the total domination that a totalitarian regime aspires to is neither arbitrary nor lawless. In contrast to tyranny, human freedom is not threatened by the partial will of a sovereign. Rather, the radical denial of freedom is 'justified' by appealing directly to those 'sources of authority from which positive laws [receive] their ultimate legitimation' (OT: 461-462). The 'lawfulness' of the totalitarian regime derives from its appeal to a standard, such as the Law of Nature (Nazism) or the Law of History (Stalinism), which transcends the world of plural individuals (OT: 349-350). Totalitarianism forgoes the 'petty legality' of positive law by applying this ultimate law 'directly to mankind without bothering with the behaviour of men' (OT: 462; EU: 339-340). Consequently, it makes the partial will of every individual 
superfluous (including that of the ruler) in relation to the overwhelming necessity of an ultimate end.

The horrible novelty of totalitarian rule is that it makes terror its organising principle (OT: 467). ${ }^{1}$ The difference between the experience of fear instilled by the tyrant and the terror inflicted by the totalitarian regime is that, whereas some limited form of freedom and society is still possible under tyranny, totalitarianism destroys the possibility of meaningful action entirely by making individuals superfluous (EU: 357). ${ }^{2}$ The tyrant creates a 'desert of neighbourlessness and loneliness' by doing away with the laws, which create a space for political action as the city walls protect a polis (EU: 344; HC: 194-195, 202-203). Though individuals are atomised when returned to the fallen state of nature by the arbitrary will of the tyrant, they retain a 'minimal, fearful contact' with one another (EU: 344). By contrast, totalitarianism obliterates the space between individuals by compressing them into one collective subject within the 'iron band' of terror (OT: 465-466; EU: 342). In leaving no space for politics, terror robs them not only of their public freedom but of their world.

This deprivation of a common world is realised even more radically in the death camps. According to Arendt, the Nazi death camps served as laboratories in which the totalitarian belief that 'everything is possible' was verified (OT: 437). This was achieved by altering human nature, which had previously been accepted as a limit to domination. In the camps, the Nazis sought to eliminate human 'spontaneity itself' by reducing each inmate to a 'bundle of reliable reactions' (OT: 448-459; EU: 240). Total domination was brought about by a threefold destruction of the individual integrity of each inmate prior to her eventual extermination. First, the juridical person was destroyed through the arbitrary selection of the victim. Certain people were placed outside the law according to an 'objective' category so that there was

\footnotetext{
${ }^{1}$ Arendt thus adds totalitarianism to Montesquieu's taxonomy of government. For Montesquieu honour is the guiding principle and criteria of a monarchy, virtue that of a republic and fear that of tyranny (OT: 467; EU: $329 f$.).

${ }^{2}$ Fear ceases to be a reliable guide for action since victims are selected according to the categories they happen to fall within rather than their particular deeds or opinions. 'Under totalitarian conditions, fear probably is more widespread than ever before; but fear has lost its practical usefulness when actions guided by it can no longer help to avoid the dangers man fears' (OT: 467; EU: 348).
} 
no correlation between 'guilt' and the actions or opinions of those arrested. Second, the moral person was destroyed by removing her from a social context in which action could be meaningful. Since inmates were made complicit in the perpetration of crimes against each other it was impossible to do good. Moreover, the isolation of the camps from the rest of the world and the prohibition of grief and remembrance made even martyrdom impossible since death was anonymous (OT: 452). Third, the uniqueness of the person was destroyed through the institutionalisation of torture. Intense suffering was inflicted not to elicit speech from or punish the victim but to reduce her to a biological specimen capable only of predicable reactions. This bundle of reactions, that allowed herself to be led to her death without protesting, was the ideal 'citizen' of the totalitarian state (OT: 455-456).

As Villa (2001: 143-145) argues, Arendt is led to a more positive conception of politics than is to be found in Locke's sober liberalism precisely because she formulates it against the experience of terror rather than fear. Rather than wanting to limit politics to avoid the worst, as do Locke and Shklar, Arendt turns to politics to recover meaning and value in human affairs in the wake of their radical negation under totalitarian rule (HC: 4 ; BPF: 149f.). Totalitarianism is world-destroying because it makes individuals superfluous. To resist the legacy of the death camps - our fearful recognition that what has happened before could also happen again - Arendt appropriates for modernity the Ancient Greek vision of the world-disclosing potential of politics. This leads her to conceive political action and judgement as activities through which 'sharing-the-world-with-others comes to pass' (OT: 438; BPF: 221).

The concept of world is at the centre of Arendt's thought. A world exists 'in-between' those who share a common political space (EJ: 262-263; LM II: 201; MDT: 10). The world is an artifice made up of all those objects created through work. This artifice, in its thingly solidity, gives a measure of durability to life by providing an enduring physical environment to house the transient affairs of human beings (HC: 137, 152, 182; BPF: 202). But the world also has an intersubjective dimension, which consists of all those intangible relationships, institutions and practices that define the public space in which we move (HC: 52-55). This 'web of human relationships' overlays the human artifice and invests it with meaning (HC: 182-183). 
Without the web of human relationships the world would be a heap of unrelated things' and without 'the intermediary, stabilising and solidifying influence of things' human affairs would be 'floating' and 'futile' (HC: 182, 204).

Humans depend on sharing a world in common, according to Arendt, not only to guarantee their mutual security but to experience meaning in their lives (HC: 4, 27; BPF: 71; LKPP: 14, 74). The sharing of words and deeds and the actualisation of freedom are what 'make it worthwhile for men to live together' (HC: 196-197; BPF: 146). A world enables us to live a fully human life, rather than merely existing, since it provides us with a sense of reality that comes from appearing before others. It mediates relationships with others, which emerge from our engagement in public action and speech. Moreover, it provides some measure of permanence to redeem the transience of human existence by establishing the conditions for a collective remembrance; it enables us to recount a history of those events we have woven together through our inter-action in the public space we share with generations past, present and future (HC: 60). The sense of reality, relationship with others and permanence that the world imparts to human affairs depends on the conditions of appearance, plurality, frailty and contingency. As I discuss below, each of these terms is fundamental to Arendt's conception of the world and her account of the circumstances within which politics is enacted in the world. As such, each serves as description (with which she illuminates the predicaments and possibilities of politics) and norm (by which she condemns totalitarianism and shows a way to resist its legacy).

For Arendt, the world is, foremost, a space of appearances. As such, it is both the 'arena' and 'reference point' of politics (Biskowski 1993: 879). Arendt (1990: 85) insists that political appearances are meaningful in themselves against the tendency to understand appearances as emanations of a higher truth or as the effects of an agent that acts 'behind the scenes' of politics (HC: 183-186; LM I: 19-40; see Villa 1996: 80-109). Everything that appears in public is relative by definition since politics is enacted within a web of relationships (MDT: 27). Consequently, there are no absolute or selfevident moral truths in politics but only contestable opinions, which announce how the world seems to those who act and speak together (Arendt 
1990: 78). Yet this does not mean that opinions are merely subjective. Rather, politics enables us to overcome the isolation of our subjectivity by disclosing an inter-subjective reality. For our actions and opinions to have significance they must be seen and heard by others and must refer to a common object (HC: 50-58). As arena, the world provides a space for politics in which individuals can appear before each other (EU: 20,17; MDT: 3 ). This space of appearances is brought into existence whenever people come together to engage in a collective effort to transform the world or to enter an incessant discourse about how the world appears to each of them (HC: 199f.). As reference point, the world is the common object of our actions and judgements (HC: 182). We can be certain that the world has 'an existence independent of the act of perceiving' only through our confirmation that the objects we perceive also appear to others (LM I: 46; HC: 208).

Arendt affirms appearances in politics because our sense of reality depends on the 'existence of a public realm into which things can appear out of the darkness of sheltered existence' (HC: 50, 199). So long as our experiences remain intimate and solitary and are not publicly shown or spoken about, they remain entirely subjective and so lack reality (OR: 96; LM I: 50). Our common sense of reality is arrived at not by interpreting the world according to an invisible, causal law of Nature or History but by appearing before others and sharing with them how the world seems to us (HC: 50-51; LM I: 19; OR: 98; Arendt 1990: 87). In contrast to Arendt's idealised image of the polis as a space of appearances in which actors strive for public recognition, the death camps were 'holes of oblivion' into which victims were made to 'disappear in the literal sense of the word' (OT: 442). The camps were pervaded by a peculiar unreality such that the victims doubted what was happening right up until their deaths. Those who survived doubted the truth of their own testimonies (OT: 439). This unreality was manufactured by radical measures that treated people 'as if they no longer existed, as if what happened to them were no longer of interest to anybody' (OT: 445). ${ }^{3}$

\footnotetext{
3 'It is not so much the barbed wire as the skilfully manufactured unreality of those whom it fences in that provokes such enormous cruelties and ultimately makes extermination look like a perfectly normal measure...these gruesome crimes took place in a phantom world...which is complete with all sensual data of reality but lacks that structure of consequence and responsibility without which reality remains for us a mass of incomprehensible data' (OT: 445). Similarly, Arendt highlights the world-curtailing effects of
} 
Plurality, the fact that the world appears differently to those who are involved with each other in the public realm, defines the 'predicament from which politics must start' (Canovan 1992: 100). Plurality is the source of uncertainty and frustration in politics. Because in politics we do not act alone but always with different others, action rarely achieves it goal. Actors have little control over the outcomes of their actions because every act 'falls into an already existing web' of 'innumerable, conflicting wills and intentions' (HC: 184; BPF: 164-165). Nevertheless, plurality is not primarily an impediment to public life, a source of conflict that should be overcome through a fusion of horizons (as in recognition) or mitigated by limiting politics (as in toleration). Rather, we depend on plurality for our sense of the reality and worth of things. Our feeling for reality depends upon the disclosure of the world as an object held in common but perceived from a multitude of perspectives (HC: 57; LM I: 64). The commonness of the world is not merely revealed, then, but is constituted by contesting reality through political interaction (HC: 198; OR: 93). Each distinct perspective that is brought to bear in the public sphere forms part of the web of human relations. By publicly revealing how the world 'opens up' to him, an agent initiates a relationship with those he addresses and, in doing so, 'inserts' himself into the world (Arendt 1990b: 80; BPF: 51; HC: 176). As such, plurality is not merely a condition of politics but its achievement - a potentiality that is actualised through action.

Arendt affirms plurality in politics because we depend upon sharing how the world opens up uniquely to each of us in order to experience meaning. Only if it remains an object of 'incessant and continual discourse' does the world appear meaningful and comprehensible (MDT: 30). Moreover, in contesting reality the distinctness of each individual is revealed. It is this experience of difference, the disclosure of 'who' the other is in her actions and judgements, that makes political communication both pleasurable and worthwhile. In the absence of the peculiarly human desire to distinguish ourselves in front of others, signs and sounds would be sufficient to communicate identical needs and wants as they occur to us (HC: 176; LM

torture when she writes that intense bodily pain 'deprives us of our feeling for reality...There seems to be no bridge from the most radical subjectivity in which I am no longer

"recognisable," to the outer world of life. Pain, in other words, truly a borderline experience between life as "being among men"...and death, is so subjective and removed from the world of things and men that it cannot assume an appearance at all' (HC: 51). 
I: 98; LKPP: 70). Indeed, this is precisely what totalitarianism aims to bring about, since it 'strives to organise the infinite plurality and differentiation of human beings as if all of humanity were just one individual' (OT: 438). As such, the totalitarian impulse is driven by a resentment of plurality and the frustrations it leads to in politics. Whereas the ideal of plurality is predicated on the simultaneous presence of a multitude of partial perspectives from which the world might be disclosed in its commonness, totalitarianism seeks to order the world in terms of an Absolute, an ultimate standpoint (the end of History or Nature) that transcends the fray of politics entirely.

The common world that is disclosed through politics is frail since its realisation depends upon the 'unreliable and only temporary agreement of many wills and intentions' (HC: 201). Because the space of appearances exists only so long as people act and speak together, it can vanish as suddenly as it springs up (HC: 199-201; BPF: 153; OR: 175, 255f.). While the possibility of the space of appearances enduring through time depends upon its formal constitution, its preservation depends upon its ongoing actualisation through public action and speech (EU: 315 ). Yet the space of appearances is also threatened by politics itself (BPF: 63; OR: 232). The frailty of the world, in this sense, arises from human natality, the fact that in action we are free not simply to deliberate and decide within a given set of possibilities but to do the 'wholly unexpected', to initiate something entirely new. The laws and institutions that define the space of appearances are thus susceptible to the 'onslaught with which each new generation must insert itself' into a world that precedes it (HC: 191; OT: 465; OR: 28).

Arendt presents the world, in its frailty, as the object of political responsibility (see Williams 1998; Biskowski 1993: 879-885). Frailty establishes a responsibility of care for the world, the importance of which transcends the immediate concerns and interests of the self (BPF: 242). As that which we share not only with our contemporaries but with past and future generations, we have a responsibility to preserve and pass on the world as a 'place fit to live' (BPF: 95). Political responsibility thus involves an openness and responsiveness to the play of the world. ${ }^{4}$ Genuine political

\footnotetext{
${ }^{4}$ Following Gadamer, 'Play is not something a subject does; rather it is a structure of human reality, a universal dynamic that is not initiated by the willing ' $\mathrm{I}$ ' but draws the ' $\mathrm{I}$ ' into its
} 
action is associated with doing the public thing; it is undertaken for the sake of the world. This responsibility of care entails a gratitude for what is given, a respect for those conditions of human existence such as plurality and natality that are not of our own making and thus limit action. ${ }^{5}$ By contrast, totalitarianism is driven by the belief that 'everything is possible' (OT: 459). Its disastrous effects stem from a lack of concern for sustaining the web of human relations, its treatment of human beings as raw material from which to remake the world according to an idea (HC: 188 , note 15). By making politics a means to realise the 'perfect' society, totalitarianism destroys the fragile web of human relations (HC: 226) ${ }^{6}$

Contingency in human affairs arises from the freedom to do the unprecedented, our 'being able to do what could also be left undone' (LM II: 198). This freedom is the source of the haphazardness and moral irresponsibility' of politics (HC: 220). The consequences of processes initiated through action are unpredictable since they depend on the responses of others who are similarly free to act in unexpected and spontaneous ways. History, therefore, is a 'story of events and not of forces or ideas with predictable courses' (HC: 252). If actors are free to do the unprecedented, then they could always have acted differently in the same circumstances for better or worse. Things could always have been otherwise (BPF: 242-243). Against the authentic origin and communal end presupposed by recognition, the beginning of action is indeterminate and the outcome of interaction uncertain.

Arendt affirms contingency because it is inseparable from the gift of freedom (HC: 244; LM I: 198). We actualise our freedom by beginning something new when we act in the world. By initiating something new we realise our humanity. According to Arendt, it is primarily our ability to begin, rather than the capacity for reason (Locke) or strong evaluation (Taylor), that distinguishes humans from other animals (HC: 176; CR: 179;

movements. Play, a goal-less, to and fro movement, transcends human subjectivity, and draws human beings into its field' (Feldman 1999: 10).

5 JP: 246; RV: 85; OT: 301; HC: 2; see Canovan 1997: 18-20; Kateb 1984: $165 f$.

${ }^{6}$ As Ricoeur (1983: 68) observes the frailty of human affairs and the political enterprise provides not only a guideline for understanding the perplexities of modern politics but a normative principle by which to judge the eclipse of politics as the supreme expression of free action and to condemn all the attempts to dissolve politics into human engineering'. 
BPF: 169; see Bowen-Moore 1989: 37). Beginning coincides with revealing 'who' we are, our difference that is not reducible to identity (HC: 179). By contrast, the death camps were a 'ghastly experiment of eliminating...spontaneity itself as an expression of human behaviour and transforming the human personality into a mere thing' (OT: 438). ${ }^{7}$ Since natality always manifests itself in the world as an 'infinite improbability', it contradicts the necessity of the Laws of Nature or History and so poses a threat to total domination (BPF: 169). In executing such a law, the totalitarian regime is driven to destroy spontaneity, which 'cannot be explained on the basis of reactions to environment and events' (OT: 455).

Appearance, plurality, frailty and contingency are descriptive terms, which define the predicament of politics, the circumstances within which politics is enacted in the world. Yet, when juxtaposed against the wrongs perpetrated in the death camps, it is clear that they are also normative terms, which define Arendt's positive vision of the political. ${ }^{8}$ Arendt's description of the conditions and world-disclosing potential of politics leads to a normative understanding of the world as 'the highest good of man' (HC: 318). This ethic of worldliness establishes a responsibility to engage in politics. We have a responsibility to act and judge since these are the activities through which we constitute and preserve the world. The end of politics is 'to establish and keep in existence a space where freedom as virtuosity can appear' (BPF: 154-155). The political, in this sense, is always 'ultimately concerned with the meaning of our life in common' (Villa 1996: 32). Worldliness also refers to a certain spirit that should animate politics (see Villa 1996: 23; Benhabib 1996: 146). This entails gratitude to the world and recognition of the limits, as well as the possibilities, that appearance, plurality, frailty and contingency establish in political life. ${ }^{9}$ Following

\footnotetext{
${ }^{7}$ In the death camps, the life of inmates is reduced to a 'dragged-out process of dying' (OT: 446) Moreover, the'status of the inmates in the world of the living is...such that it is as though he had never been born' (OT: 444).

${ }^{8}$ The concept of the political is best understood as an ideal which must be distinguished from the actual activity of politics, which is typically a 'continuous, ceaseless and endless' contest over public goods (Wolin 1996: 31).

9 In Arendt's own references to the notion of 'worldliness', she tends to associate it more narrowly with the activity of work, the 'capacity to fabricate and create a world' (e.g. BPF: 209; HC: 7, 236). However, I interpret worldliness more widely as an animating ideal for the activities of acting and judging that constitute the web of human relationships. Kateb (1984: 2) describes worldliness similarly as 'a common commitment to the reality, beauty and
} 
Arendt, then, all that is undertaken for this end and in this spirit is political, all that is irrelevant to the world we share in common is unpolitical and all that undermines the world-disclosing potential of politics or is animated by a resentment of worldly conditions is anti-political (see Kateb 1984: 22-28).10

\subsection{The promise and risk of action}

We have seen how Arendt turns to the world-disclosing potential of politics to recover meaning and dignity in human affairs against the worlddestroying anti-politics of totalitarianism. Yet there is an ambivalence in Arendt's affirmation of the political since, although she invites action for the sake of freedom and meaning, she is wary of its destructive impact on the world we share in common. The promise of action is the possibility of a new beginning, the generation of relationships and the disclosure of a world in common. Yet, this promise entails a risk since action also initiates boundless, unpredictable and irreversible processes that threaten to overwhelm the fragile web of human relationships. If the promise of action is the source of hope and faith in politics, its risk often leads us to regard politics with fear and suspicion.

Arendt's account of the promise and risk of action leads to a tension in her work between her affirmation of political interaction as animated both by agonistic-striving (actualising freedom by distinguishing ourselves through a conflictual and open-ended inter-action with others) and care-for-the-world

sufficiency of the culture or way of life that sustains political action, as well as a commitment to political action itself. Political action looks in turn to the conservation or augmentation of the way of life that sustains it.'

10 This Arendtian distinction between politics and 'the political' more or less reverses the Schmittian distinction proposed by Chantal Mouffe. According to Mouffe (2000: 101), the political refers to 'the dimension of antagonism that is inherent in human relations, antagonism that can take may forms and emerge in different types of social relations. 'Politics' on the other side, indicates the ensemble of practices, discourses and institutions which seek to establish a certain order and organize human coexistence in conditions that are always potentially conflictual because they are affected by the dimension of 'the political". I think it is important to invert these terms in order for the concept of the political to do the normative work I want it to. However, rather than eliding what Mouffe calls the 'dimension of antagonism' I propose to capture it with the concept of the 'risk of politics', which I develop further in 4.2. If, with this reversal, I go astray by reducing the political to the ethical, I would prefer to do so with Arendt than, following Schmitt, to reduce the political to the moment of decision (see Mouffe 2000: 134-135). 
(acting in concert for the sake of realising and preserving the fragile web of human relationships) (see Kateb 1984: 33-34). Recognition of the frailty of the world engenders a concern with establishing durability and stability in human affairs. As response to frailty, politics concerns sustaining a world in common through remembrance, respect for limits and the establishment and maintenance of a space of appearances. Yet, recognising contingency unsettles our being at home in the world by exposing the haphazardness of politics. The insecurity engendered by recognising contingency is, however, inseparable from realising our freedom since it 'challenges the belief in necessity, the acquiescence in the arrangement of the world' that leads to apolitical complacency (LM II: 196). Despite its unsettling effect, contingency must be affirmed in politics for the sake of freedom, the recognition of novelty in human affairs and the openness of the future. ${ }^{11}$ Following Arendt, the promise and risk of action presuppose each other. To make good on the promise of action we must be prepared to assume its risk. But, conversely, an agonistic politics is only coherent in the context of a shared commitment to realising a world in common. The world-disclosing potential of politics thus depends upon inviting both the promise and risk of action, its worlddelimiting and world-rupturing moments. Politics emerges as an unding (and ultimately impossible task) of reconciling the boundless potentialities of initiatory action with the limits and frailty of the world.

The promise of action depends on its revelatory quality. According to Arendt, as we have already seen, by beginning something new we 'insert ourselves' into the world (HC: 176). Initiatory action discloses both the unique identity of the actor and the commonness of the world that lies between her and those she acts among. The 'who' that is revealed in action and speech (a distinctness that becomes apparent in distinguishing oneself before others) is not reducible to 'what' one is (the qualities and attributes with which we identify and by which others identify us) (HC: 178-181).

\footnotetext{
${ }^{11}$ I take this tension to arise from a real and unavoidable predicament of action, which cannot be dispensed with by drawing selectively on only one aspect of Arendt's theory of action as some interpreters propose to do. Deliberative democrats seize on the consensusoriented promise of action but want to dispense with its risk: that consensus is not an inevitable outcome of inter-action (e.g. Benhabib 1996: 118, 125-126; d'Entrèves 1994: 85, 153156). Radical democrats, by contrast, suspect that the promise of realising a world in common is a ruse for domination and so affirm action only as an incessant contest that resists the closure of a normative order (e.g. Honig 1991: 108; Villa 1996: 206 - but see also Villa 1999: 107-127).
} 
Rather, the 'who' of the agent is revealed through the unique story she enacts in the world. Since we always act among others who are similarly capable of spontaneous action, our unique life story unfolds through our interaction in the world. Moreover, through this interaction we uniquely affect the lifestories of others and, in doing so, generate relationships with them (HC: 184). Action discloses the world in its commonness because the web of human relationships is constituted through interaction. The stories that are enacted in the world are the source of meaning in human affairs. As the outcome of our interaction, individual life-stories and common histories reveal relationships between people, events, places, things, words and deeds in time and space. They give coherence to human affairs by providing a meaningful context within which to make sense of our acting and suffering.

If the promise of action lies in its revelatory character, the risk of action derives from our lack of mastery over its consequences. As Schmitt (CP: 58, 61) recognises, the freedom to act anew means that human beings are 'dangerous and dynamic', 'risky' rather than 'harmless' creatures. Yet Arendt breaks decisively from Schmitt and, indeed, Locke and Taylor in her insistence that freedom is given to humans 'under the condition of nonsovereignty' (HC: 244). For Arendt, the ideal of sovereignty 'uncompromising self-sufficiency and mastership' - is anti-political because it contradicts the condition of plurality (HC: 234). The ideal of sovereignty is based on the solitary experience of making, according to which we use and master nature for our own ends (HC: 140). But it is inappropriate to generalise this experience to political life. For, in the process of fabrication, what we do is determined, judged and justified by the end we seek to realise, the outcome we want to produce. By contrast, the end of action is always unpredictable because it relies on the re-actions of others on whom we depend for our sense of self and world. The traditional identification of sovereignty and freedom in political philosophy, then, necessarily leads to despair at the haphazardness of politics and the almost inevitable failure of action to achieve its goal (HC: 235). ${ }^{12}$ Against this tradition Arendt associates freedom with beginning rather than the pursuit of ends.

\footnotetext{
12 'If we look upon freedom with the eyes of the tradition, identifying freedom with sovereignty, the simultaneous presence of freedom and non-sovereignty, of being able to begin something new and of not being able to control or even foretell its consequences, seems almost to force us to the conclusion that human existence is absurd' (HC: 235).
} 
Arendt's understanding of freedom as non-sovereign leads her to conceive the risk of politics more broadly than Schmitt's important, but ultimately reductive, concept of the ever-present possibility of the friendenemy relation. For Arendt, the risk of action is apparent in its boundlessness, unpredictability and irreversibility. Since every act falls within a pre-existing web of conflicting wills and intentions, it initiates a process of re-actions that fundamentally alters the constellation of existing relationships and has the potential to endure indefinitely in the world (HC: 233). Every process outlasts its initiating act and tends to grow in strength, while its consequences multiply as it works its way through the web of human relationships. Consequently, there is an inherent tendency in action to 'force open all limitations and cut across boundaries' (HC: 190). This lack of mastery over the consequences of our actions leads to 'a cruel paradox' in that 'by producing the web of human relationships', action 'seems to entangle its producer to such an extent that he appears much more the victim and the sufferer than the author and the doer of what he has done' (HC: 233234). While the risk associated with the irreversibility of action is that we cannot free ourselves from the consequences of past deeds, the risk associated with its unpredictability is that we are unable to establish any continuity in our relations with others (HC: 237).

The predicaments and frustrations of non-sovereign freedom give rise to the temptation to try to 'eliminate [the] risks and dangers' of action by organising politics according to a relationship of command and obedience (HC: 230). ${ }^{13}$ In order to 'escape the haphazardness and moral irresponsibility inherent in a plurality of agents' for 'the solidity of quiet and order', humans have often sought to exercise sovereignty in public affairs (HC: 220, 222). In order to master action from beginning to end, the polity is divided between those who decide the ends of the political association and those who 'act' by executing the sovereign will. Conceived in terms of command and obedience, politics becomes a means to achieve the undivided will of a

\footnotetext{
13 'Humans have long been aware of the predicaments and perplexities of action. 'They have known that he who acts never quite knows what he is doing, that he always becomes "guilty" of consequences he never intended or even foresaw, that no matter how disastrous and unexpected the consequences of his deed he can never undo it, that the process he starts is never consummated unequivocally in one single deed or event, and that its very meaning never discloses itself to the actor but only to the backward glance of the historian who himself does not act' (HC: 233).
} 
sovereign entity. Yet instrumentalising politics in this way eliminates the risk of action by denying its promise. Stability and security in human affairs are won at the cost of freedom and meaning since plurality must be denied for the higher purpose to which action is subordinated (HC: 229). The end toward which the sovereign seeks to mould society becomes an absolute standard that is incontestable. Action is judged according to its success or failure in achieving this predetermined end, whether it be, for example, the historic destiny of the nation or the happiness of the greatest number. Yet the instrumentalisation of politics can only lead to the generation of meaninglessness in human affairs because it deprives action of its revelatory quality (HC: 180, 153-159, 207-212).

Arendt therefore accounts for the meaningfulness of action in terms of its performative rather than its strategic character and frequently likens politics to the performing arts. ${ }^{14}$ As with drama and dance, the accomplishment of action 'lies in the performance itself' rather than its origin or end (HC: 153; LM I: 131). The meaning of action cannot be construed either in terms of its causes or its consequences. Rather, action is meaningful to the extent that it is exemplary and free to the extent that it springs from an inspiring principle rather than being determined by motives or goals (BPF: 152; OR: 212-213). A principle, in this sense, is not the same as a rule, as in Kant's categorical imperative (see Villa 1996: 139-140). A principle does not direct but animates political action and, as such, is only manifest so long as the act lasts (HC: 206). The principled act exemplifies some aspect of our common experience of the world such as, for instance, what it is to show mercy, fear, courage or solidarity. The free act is, in this sense, 'endconstitutive' (Villa 1996: 32). It does not reflect a choice between predetermined ends, but exemplifies what those ends should (or should not) be.

Arendt's rejection of what Taylor calls expressivism, that is, the Romantic ideal of self-realisation, is closely related to this performative conception of action. The revelatory quality of action is not the expression (or repression) of an authentic self. Rather one's self is actualised in appearing before others (LM I: 29). Arendt rejects the notion of a unitary subject that lies behind appearances and causes its effects in the world (Villa 1996: 90 f.;

14 HC: 187-188, 207; BPF: 153; OR: 106; see Villa 1996: 52-59 
Honig 1992: 217). When we are alone the self is indistinct and divided. It is only when we appear before others that the self is drawn together and constituted in the world (LM I: 37; Arendt 1990: 86, 88; Honig 1988: 77). The self does not precede and determine action, then. It is not something one ought or could 'be true to' (Taylor, SS: 30). Rather, actor and act coincide, the identity of the agent is constituted in action. Moreover, the revelation of the self through action is decentred (Villa 1996: $92 \mathrm{f}$.). For, although the 'who' disclosed in action 'appears clearly and unmistakably to others, [it] remains hidden from the person himself' (HC: 179). While the actor exercises some discretion in self-presentation, self-disclosure can 'almost never be achieved as wilful purpose' (HC: 179; LM I: 36). Similarly, because the individual plays a part in a story of which he is not the author but its actor and sufferer, his perspective is always partial. The significance of the events he participates in and the meaning of his action is never revealed to him as fully as it is to the spectators who judge the whole from a more disinterested and less partial perspective (HC: 192; LKPP: 68-69).

In politics, just as in the performing arts, 'virtuosity of performance is decisive' (BPF: 153). Virtù serves a similar role in Arendt's ethic of worldliness as it does in Machiavelli's realism since it distinguishes an ethical mode appropriate to political life from everyday morality. Like Machiavelli, Arendt wants to separate political virtue from its association with moral character (BPF: 137). ${ }^{15}$ However, since she rejects necessity as an anti-political ground for action, Arendt refers to virtù only in terms of the 'excellence' with which the actor 'answers the opportunities the world opens up before him' rather than his willingness to do what is necessary (BPF: 153, 137). Virtù has a double sense as both the excellence of the deed and the skilfulness with which it is performed (BPF: 137, 153). The excellence of an act depends upon its revelatory quality, its power to illuminate the significance of our life in common (BPF: 248; LKPP: 84). To the extent that it is exemplary, action is extraordinary and possesses a 'shining quality' (BPF: 47 ; $\mathrm{HC}: 42,205)$. On the other hand the skilfulness or virtuosity of the act

\footnotetext{
15 Those worldly virtues revealed in action such as spontaneity, excellence, moderation and courage, are coincident with the performance itself (BPF: 275-276). They do not refer to a given quality of the actor, which precedes her appearance in the world and are actualised in action. Rather, they are called forth from the agent as she responds to the play of the world (HC: 207).
} 
depends on the mastery of self-presentation, the actor's ability to 'find the right words at the right moment' (HC: 26; LM I: 34-37). Against fidelity to an authentic self, virtuosity requires that one appears as one wishes to be (OR: 101).

Since the world-disclosing potential of politics depends upon the revelatory, performative quality of action, Arendt is led to affirm action as agonistic-striving. The agonal spirit of politics arises from the 'urge toward self-disclosure', the desire to distinguish oneself before one's equals (HC: 194, OR: 33, 120). Humans are 'roused to action in order to find their place in the society of their fellow-men' (LM I: 70). ${ }^{16}$ The desire to distinguish oneself leads to conflict and disagreement between actors. Agonism thus refers to the 'resistibility, openness, creativity, and incompleteness' of political life against necessity, irresistibility, compulsion and determination, which leave no space for politics (Honig 1992: 217). The affirmation of agonism requires an openness and ongoing responsiveness to others and to the world, a willingness to share the world with different others (MDT: 15, 6). This means taking pleasure in the play of perspectives, enjoying politics for its own sake rather than wanting to bring to a close the activity of persuading and being persuaded (BPF: 233-234; see Villa 1999: 118-119). To engage in such an agonistic politics requires courage. For, in being exposed to the light of the public sphere, the agent must forsake 'the comforting security of "what" it is, the roles and features that define (and even) determine it in the private realm' (Honig 1992: 219). Courage is inherent in a willingness to act and speak in the first place, to 'risk the disclosure' of who one is by appearing before others (HC: 180, 186-187; see Kateb 1984: 34-35).

Yet, just as the musician and the dancer are dependent upon an audience in order to give a performance in which they can reveal their virtuosity, so is the political actor dependent upon an audience of spectators to distinguish herself in the world (LM I: 132-133; HC: 198; BPF: 154). The frailty of human affairs arises due to the intangibility of the 'products' of action and speech, the fact that these activities leave nothing behind but 'exhaust their full meaning in the performance itself' (HC: 206; BPF: 44-48). The 'utterly fragile meaning' that action produces depends upon attentive

\footnotetext{
16 See HC: 24-25, 41, 77, 194, 197; OR: 119-120, 275; BPF: 67; Arendt 1990: 82.
} 
witnessing by others if it is to be established in the world (HC: 196; BPF: 44$45,84)$. Through the constitution of a permanent space in the world in which citizens can appear before each other, the polity makes the extraordinary revelation of action an everyday possibility. Moreover, political society provides a measure of permanence and durability to human affairs by creating the possibility of an 'organised remembrance' (HC: 198; BPF: 71-72, 218). The meaningfulness of events, words and deeds can only take their place in the world, can only become tangible through their remembrance in narration and reification in art (BPF: 209).

The world-disclosing promise of action is inherent in its performative character, then, and so is inseparable from the open-ended, agonistic contest of politics, the clash of world-views. Consequently, the promise of action always entails risk. For, if an agonistic politics goes unchecked by care-forthe-world, the boundless, unpredictable and irreversible processes initiated through action threaten to rupture the fragile web of human relationships (Arendt 1990: 82; OR: 144). This frailty imposes a responsibility of care that is, to some extent, at odds with the agonism of action. Political responsibility is conservative in the sense that a claim is made on us 'to take care and preserve and admire the things of the world' (BPF: 225). Our being at home in the world depends on the durability of the human artifice, since without some guarantee of permanence the world of human affairs 'cannot offer moral men the relatively secure, relatively imperishable home they need' (MDT: 10-11; BPF: 210). A world characterised entirely by spontaneous, initiatory action would be inhospitable since it would be 'violently wrenched into a movement in which there is no longer any sort of permanence' (MDT: 11). Care-for-the-world thus lures us beyond the immediate concerns of the self, since we are called upon to take care of and preserve something that transcends our own short lives (HC: 53-57; BPF: 207 f.; OR: 230).

Care-for-the-world requires moderation. At the same time as she celebrates initiatory action, Arendt counsels a politics of limits, keeping within the bounds of the world (HC: 191; see Canovan 1997: 14-21). As we have seen, gratitude for the givenness of the world means accepting the conditions of plurality, appearance, contingency and frailty as setting limits to the possibilities of action. But care-for-the-world also requires a respect for those limits constituted in the procedures, conventions and institutions of the 
polity. ${ }^{17}$ The laws of a polity stabilise the affairs of men by institutionalising a normative order. Without respect for the boundaries law establishes between polities, between public and private and between members of the polity in the public sphere, politics would not be possible (HC: 191; OR: 275). These laws, however, are not secured by any extra-political ground (such as God, Nature, Reason or Tradition) but must be actualised through action (HC: 245; OR: 151). Institutions do not establish absolute limits to action but rather delimit a space within which meaningful action is possible. Whether action affirms or contests institutionalised norms, what is important is that these provide a common point of reference for an agonistic politics. For, to be coherent, even transgressive action must presuppose a publicly recognised limit. ${ }^{18}$

Yet, since law depends on politics for its actualisation, legal institutions cannot, in themselves, ensure the preservation of a common world. Rather, Arendt ultimately looks to the 'potentialities of action itself' for a remedy against its risks (HC: 236). Promising and forgiving are inherently political, according to Arendt, because they presuppose the presence of others. ${ }^{19}$ Moreover, they are animated by care-for-the-world, the collective responsibility to preserve the world against the ruinous excesses of unbounded spontaneity. Forgiving offers a possible redemption from the predicament of irreversibility (our inability to undo what has been done) while promising offers a remedy for the predicament of unpredictability (the uncertainty of the future). While forgiveness releases us from the grip of the past, promising assures a degree of certainty within the radical openness of the future (HC: 237). Because these faculties are central both to Arendt's political thought and to a politics of reconciliation I examine each in detail in chapters six and seven.

\footnotetext{
17 OR: 126, 223; HC: 191; OT: 465-467; BPF: 214; EU: 207, 298; see Waldron 2000

18 'What saves the affairs of mortal men from their inherent futility is nothing but this incessant talk about them, which in its turn remains futile unless certain concepts, certain guideposts for future remembrance, and even for sheer reference, arise out of it' (OR: 220).

19 'In so far as morality is more than the sum total of mores, of customs and standards of behaviour solidified through tradition and valid on the ground of agreements, both of which change with time, it has, at least politically, no more to support itself than the good will to counter the enormous risks of action by readiness to forgive and to be forgiven, to make promises and to keep them' (HC: 245).
} 
I mention promising and forgiving here to underscore Arendt's point that the inevitable risk of action cannot be mitigated or avoided by 'grounding' institutional limits (e.g. rights, equality) on a foundation that exists outside the political realm (e.g. the law of nature). Though there may, indeed, be a natural justice that exists independently of our beliefs and opinions, its actualisation in human affairs depends upon the possibility of contesting its truth, of making it a living reality within the space of appearances. It is in this sense that justice is always related to an allied regime of politics. Rather than seeking to order politics from an ultimate end that is independent of politics, we must invite the risk of politics for the sake of its promise. ${ }^{20}$

When politics goes well, the world is disclosed in its commonness from a plurality of perspectives. By engaging in an incessant discourse about the world and its affairs, the world becomes more common to us. When politics goes badly, our sense of a common world is diminished. Yet politics is most likely to run amok when we try to avoid the risk of action by 'overcoming' those worldly conditions that give rise to politics in the first place. This happens, for instance, when we seek to establish an Absolute standard in place of the relativity of opinion, treat society as a collective subject rather than a manifold of individuals or subject action to a supposed historical or natural necessity to avoid the haphazardness of spontaneous interaction. Such 'remedies' for politics end up not only undermining its world-disclosing potential but taking away our political capacities for reducing its risks. Moreover, the assumption that politics can be approached in the same manner as fabrication quickly leads to the supposition that we can similarly unmake the unfortunate consequences of our actions through the violence inherent in means-end thinking (HC: 238).

\footnotetext{
${ }^{20}$ Kateb (2000: 142) points out that it is striking that the morality Arendt claims to be inherent to political action is derived from the frailties of action rather than from its excellence. Morality thus appears as 'a tax on human endeavours rather than its crowning achievement'. Consequently, Arendt's political morality appears as an 'accommodation between action and restraint, with restraint accepted reluctantly, if perhaps magnanimously'. While, this is a fair reading of Arendt, it is somewhat partial due to Kateb's own liberal anxieties about Arendt's rejection of the feasibility of grounding rights in an extra-political morality. While these anxieties are well-stated, Kateb underestimates the ethical significance of those other aspects of Arendt's theory of action I discuss here in terms of performance, freedom and agonism.
} 
The agonism Arendt affirms in politics thus differs decisively in one important respect from that to which Schmitt draws our attention. According to Schmitt (CP: 71), liberalism trivialises politics by substituting mere talk for an agonistic politics in which individuals are willing to stake their lives to defend their moral truth. Arendt also points to the loss of the political within the terms of liberal discourse. However, she argues that genuine political speech is similarly reduced to mere talk when 'people are only for or against other people' (HC: 180). For when speech is subordinated to political ends in this way it loses its revelatory quality and becomes 'simply one more means toward the end, whether it serves to deceive the enemy or dazzle everybody with propaganda' (HC: 180). With Schmitt, then, Arendt acknowledges the emergence of the friend-enemy relation as a risk of action. However, against Schmitt, she locates friendship and the promise of action in being together with a plurality of others rather than in defending one's form of life against incursion from a hostile and alien other.

\subsection{Reflective judgement}

The world-disclosing potential of politics depends not only on action but judgement. Indeed, as the faculty through which we grasp the significance of appearances, judging is the 'other side of action' (EU: 321; see Beiner 1982: 111; Vollrath 1977: 182). As we have seen, the space of appearances is constituted by an audience of spectators to whom actors appear (LKPP: 6163; BPF: 217). As actors, we depend upon others to judge the significance of the stories we enact in the world, to preserve the fragile meaning that our action reveals. The actor never fully understands what he is doing and suffering since he sees the story from his own partial perspective (LKPP: 69). By contrast, the significance of interaction is revealed more clearly to the spectators who see the whole (LKPP: 55; HC: 192; LM I: 76, 93 f.). If action refers to the agent's freedom to begin something new, judgement refers to the spectator's recognition of the unprecedented and his discernment of its significance for our life in common (HC: 205; LKPP: 62; EU: 320).

Arendt appropriates Kant's third critique of aesthetic judgement to formulate her theory of political judgement. Kant's account of judgement is inherently political, according to Arendt, because it presupposes the 
conditions of appearance, plurality and contingency. Aesthetic taste and political opinion are closely related because they are both concerned with judging the particular qua particular, according to its appearance rather than its purpose. Further, both presuppose the presence of others who we want to agree with our judgements of worth. Finally, neither taste nor political opinion compel with the force of reason but rather persuade by appealing to common sense. ${ }^{21}$ As I show below, Arendt's aestheticisation of political judgement extends and completes her performative account of action (see Beiner 1982: 104; Villa 1996: 99-109). On this account, political judgement involves two mental operations. These are representation, by which we imagine the object from a plurality of viewpoints in order to establish an impartial perspective, and reflection, by which we find a general concept to make sense of the particular (LKPP: 68). Since the validity of reflective judgement depends upon an appeal to common sense rather than natural law, I argue, it avoids the political pessimism that Locke's privileging of knowledge over opinion leads to (see 2.2). Moreover, since it aims to grasp the meaning of the particular qua particular, it resists the anti-political moment of recognition without giving way to indifference (see 3.3 and 3.4).

Aesthetic judgement is based on taste. Yet, as Arendt observes, taste and smell are the most subjective and private of senses because they refer to an inner sensation rather than an external object. As such, taste and smell are inherently discriminating. One can suspend judgement about the objects we see, hear and touch but 'in matters of taste or smell, the it-pleases-ordispleases-me is immediate and overwhelming' (LKPP: 64). Taste involves a direct relation between the sensing subject and the particular such that the 'it-pleases-or-displeases-me is almost identical with the it-agrees-with-or disagrees-with-me' (LKPP: 66). That judgement should be based on a political equivalent of taste is appropriate given Arendt's phenomenology of action as performance within a space of appearance. The world-disclosing

${ }^{21}$ As Bernstein (1986: 236) puts it: 'What drew [Arendt] to Kant's analysis of aesthetic judgement as a model for all judgement is what she took to be his deepest insight - that there is a distinctive mode of thinking which is not to be confused with cognition or with practical reason - both of which are obsessed with universality - a mode of thinking that could deal with particularity as such without subsumption and which would enable us to understand the meaning of this particularity. She also thought that Kant, as she read him, was profoundly right in stressing the intersubjectivity of this mode of thinking - that the spectator is not alone but is always appealing to and needs other judging spectators.' 
potential of politics depends fundamentally on the opinion of spectators, the 'it-seems-to-me' with which we insert ourselves into the web of relationships. Yet, the very subjectivity of taste suggests that it is a precarious foundation from which to realise a world in common. We either like something or we do not. Consequently, there seems to be no criterion beyond our immediate, idiosyncratic and private response by which to decide what constitutes good or poor taste.

However, following Kant, Arendt argues that we are able to overcome the subjectivism of taste by imaginative representation and by referring to our common sense of the world. Through imagination we remove the particular from our direct perception by re-presenting it as a thought-object. What pleases us in perception is gratifying but not beautiful (LKPP: 67). Real judgements of worth depend upon reflexivity, our capacity to 'approve or disapprove the very act of pleasing' (LKPP: 69). This reflexivity, which Taylor (PP1: 16) calls our capacity for strong evaluation, enables us to cultivate taste, to acquire a taste for some things and distaste for others. Imaginative re-presentation establishes a critical distance between subject and object that enables reflexivity and, hence, enables us to make strong evaluations. Yet, whereas for Taylor (PP1: 23) our strong evaluations depend upon the 'kind of beings we are or want to be', for Arendt they depend upon our ability to 'think in the place of everyone else' (BPF: 220). We are not content to judge in private but rather want to share our judgements of worth with others. As Kant puts it, the beautiful only interests us when we are in society (LKPP: 67). Judgement presupposes communication with others and, hence, a community of judging spectators with whom we share the world. It is by appealing to 'common sense', our sense that we perceive the same world in common with others, that judgement appeals to an inter-subjective rather than an objective validity.

The impartiality on which the spectator bases the validity of his opinion, then, is not the same as the universality that the philosopher claims for his truth (BPF: 221). Impartiality is arrived at by taking the viewpoints of others into account, by representing in one's mind a plurality of partial perspectives. By contrast, the philosopher seeks to ground moral truth on a singular transcendent standard, a 'higher standpoint' that could settle a political dispute by 'being altogether above the mêlée' (LKPP: 42; BPF: 48-52). 
This is what Locke tends to do by appealing to the law of nature to establish the right to life, liberty and property. Yet, as we saw in 2.2, while Locke presupposes that it is possible to demonstrate moral truths, which would compel with the force of demonstration, he considers that most humans are too prejudiced, partial and self-interested to 'see' such truths. He is led to advocate a limited politics because he despairs at the partiality of opinion and the conflicts it gives rise to in human affairs.

Reflective judgement similarly requires that we transcend our immediate and partial interests. However, we do so not by disengaging from our standpoint in the world entirely but by thinking representatively. In contrast to the singular standpoint of the universal, impartiality would not be possible in the absence of the many perspectives that a plurality of spectators bring to the world. For impartiality depends upon our ability to imagine the object of judgement from the partial perspectives of 'significantly situated others' (Ferrara 1998: 117). By representing the standpoints of others in our minds we seek to grasp the way in which the world opens up 'from the place where they stand, the conditions they are subject to, which always differ from one individual to the next, from one class or group as compared to another' (LKPP: 43). ${ }^{22}$ To the extent that we are able to imagine the 'different and frequently opposing aspects' through which the same object is perceived by others, our judgement is liberated from the 'private conditions and circumstances' that constrain it (BPF: 51, 220-222, 241-242; LKPP: 73, 42-43). The more perspectives one is able to imagine, the more impartial will one's judgement be (BPF: 241).23 Yet, the validity of our judgement is never universal but extends only so far as those 'others in whose place the judging person has put himself for his considerations' (BPF: 221). As such, the standpoint that we aspire to in forming an impartial judgement is the 'standpoint of the world as a common world' (Vollrath 1977: 180).

\footnotetext{
22 Thus, as Beiner (1982: 100) points out: 'Judgement may require us to make the effort to understand those whose point of view we not only do not share but may even find highly distasteful. Disagreement does not release us from the responsibility to understand what we reject; if anything, it rather heightens this responsibility'.

${ }^{23}$ Importantly, this imaginative capacity for representative thinking is not the same as empathy. Whereas empathy tends toward the uncritical acceptance of the selfunderstanding of others, representative thinking is oriented toward transcending not only our own immediate self-understandings but those of others (BPF: 222; MDT: 203).
} 
The impartiality achieved by representative thought prepares the way for the second operation of judgement. Reflection is the actual activity of judging something, by which we combine the particular with the general. With determinate judgement the particular is subsumed under a general rule or law that is already given. By contrast, with reflective judgement, the particular is given 'for which the general has to be found' (Kant in LKPP: 76). Arendt wants a standard for political judgement that is not legislative and it is for this reason that she turns to Kant's critique of judgement rather than that of practical reason. Morality, as Kant presents it in the Second Critique, is not a matter of judgement at all but of will complying to the dictates of reason. Reason lays down the law, the categorical imperative to 'always act in a manner that the principle of your action can become a general law'. As such practical reason is based on the 'necessity for rational thought to agree with itself' (BPF: 220-221; LKPP: 15). ${ }^{24}$

Arendt's distinction between the moral and the political turns on her distinction between the necessity of agreeing with oneself and the freedom to agree or disagree with others in public debate. Arendt takes the principle of non-contradiction as the defining feature of morality. This is represented not only in Kant's categorical imperative but in the declaration attributed to Socrates by Plato that 'Since I am one, it is better for me to disagree with the whole world than to be in disagreement with myself' (BPF: 220). As such, morality 'concerns the conduct of the self in its independence from others' (LKPP: 44). Kantian morality is predicated on a universal conception of 'Man' as an autonomous, rational being who is subject to the laws of practical reason which he gives to himself (LKPP: 27; 49). While moral considerations centre around the self, according to Arendt (1987: 47), political considerations centre around the world. Consequently, in politics we must always take into account the judgements of others who are free to disagree with us (LKPP: 67). As political beings, humans cannot simply lay down the

\footnotetext{
${ }^{24}$ Kimberly Hutchings (1996: 94) explains that Arendt's 'aim in her work on judgement is to create a political philosophy that does not violate her concept of politics. Crucial to Arendt's concept of politics is a notion of human activity which is not structured by the violence of truth, morality or law. The last three involve the coercion of particulars by universal determinations, whether these are the rules of the understanding or the commands of practical reason. In Kant's concept of reflective judgement, the human faculty which is lawful without law, Arendt argues that she has found what she is looking for, a political philosophy which is not a philosophy of right'.
} 
law but must court the agreement of others (LKPP: 72). As political beings, men not Man inhabit the world and, far from being autonomous, they need 'each other's company even for thinking' (LKPP: 27).

While Arendt's distinction between the moral and the political leads to a reductive account of morality, her intention is not to dispense with morality in politics. Rather, her point is that we must change the order of our moral thinking when acting in the world. We cannot order politics according to a pre-determined moral rule. Rather, we must realise morality by engaging in politics. It is for this reason that she turns to Kant's critique of aesthetic judgement rather than that of practical reason to support her politics. For practical reason, which bases moral responsibility on the ideal of autonomy, contradicts the heteronomy inherent to political interaction (LKPP: 70). Kant's moral philosophy is anti-political and, hence, inhumane because it introduces an absolute standard into the web of human relationships, which is relative by definition (MDT: 27). ${ }^{25}$ Similarly, Kant's predecessor Locke counsels a limited politics because the uncertainty of opinion prevents us from laying down the law in politics with the assurance of moral truth. For Locke, moral knowledge, which compels with the force of demonstration, is the ideal against which opinion is found wanting. By contrast, Arendt affirms opinion against the ideal of legislative reason because debate constitutes the 'essence of political life' (BPF: 241). We depend upon disagreement and debate - exchanging, contesting, compromising, reformulating and transforming our political judgements for the 'inexhaustible richness of human discourse' through which we humanise and invest the world with meaning (BPF: 234; MDT: 27).

Our ongoing sense of the reality and worth of what exists and happens in the world depends upon our capacity for reflective judgement.

\footnotetext{
25 'Kant argued that an absolute exists, the duty of the categorical imperative which stands above men, is decisive in all human affairs, and cannot be infringed even for the sake of humanity in every sense of that word...the inhumanity of Kant's moral philosophy is undeniable. And this is so because the categorical imperative is postulated as absolute and in its absoluteness introduces into the interhuman realm which by its nature consists of relationships - something that runs counter to its fundamental relativity. The inhumanity which is bound up with the concept of one single truth emerges with particular clarity in Kant's work precisely because he attempted to found truth on practical reason; it is as though he who had so inexorably pointed out man's cognitive limits could not bear to think that in action, too, man cannot behave like a god' (MDT: 27).
} 
According to Arendt, most of our concepts originate in a particular historical incident, which then becomes exemplary in that we perceive in this particular 'what is valid for more than one case' (LKPP: 85; OR: 35). Sensitivity to appearances enables us to discern the unprecedented event, the significance of which resists articulation within our existing categories of judgement. In the case of the unprecedented, a particular is given for which a general must be found; the particular must be 'brought to' rather than 'subsumed under' a concept (LKPP: 83). This is possible through the use of example. To judge through use of example is to single out a particular, which 'in its very particularity reveals the generality that otherwise could not be defined' (LKPP: 77). In this way, the exemplar retains its experiential referent even as its meaning is abstracted. For instance, in saying 'courage is like Achilles' we refer to a general aspect of human experience without abstracting this entirely from the particular circumstances in which it appeared (LKPP: 84, 77). The exemplar thus 'discloses generality without surrendering particularity' (Beiner 1982: 130).

Arendt's aestheticisation of judgement follows naturally from her performative account of action. What the beautiful and the human person have in common is their purposelessness, that they both must be understood as ends in themselves (LKPP: 77). To justify the existence of either in terms of causes or consequences is to debase them. Similarly, to judge action in terms of its success or failure rather than its revelatory quality is to derive its meaning from an assumed historical process, which transcends human affairs (LKPP 5, 56). However, human dignity demands that the individual 'be seen...in his particularity' (LKPP: 77, 26). As discussed in 4.2, it is by disclosing who we are in action that we realise our humanity. Yet this who resists articulation. For in trying to say who a person is we usually find ourselves describing what he is: 'we get entangled in a description of qualities he necessarily shares with others like him; we begin to describe a type...with the result that his specific uniqueness escapes us' (HC: 181). Arendt here describes what I referred to in 3.3 as the anti-political moment of recognition, the reduction of difference under identity. Just as recognition misses the uniqueness of the other to the extent that it neglects non-identity, the problem with determinate judgement is that, by subsuming the particular under a rule, it tends to reduce rather than release meaning. By contrast, Arendt's theory of reflective judgement seems to offer or, at least, suggest a 
mode of 'reflective openness indefinitely postponing the moment of positiveaffirmative closure', which we earlier saw as an enabling condition of political reconciliation (Dallmayr 1997: 36; see 3.4). ${ }^{26}$

The pleasure of judgement coincides with our heightened sense of the real. Arendt insists that 'judging is one, if not the most, important activity' through which the world is disclosed in its commonness (BPF: 221). This is so, since our judgements must be communicable to be valid and, as such, they must appeal to common sense. Reflective judgement has 'exemplary validity' to the extent that an appropriate particular is singled out as exemplifying a general principle. I present my judgement 'as an example of common sense, and attribute to it on that account exemplary validity' (Kant quoted in Beiner 1982: 121). Common sense refers to our common sense of the world, that intersubjective feeling for reality which depends upon our acting and speaking in public. This includes 'community sense', the received wisdom of custom and social mores. Yet, reflective judgement can only refer to this community sense in order to call it into question. For what dulls our sensitivity to appearances is an habitual reliance on inherited prejudices and doctrines, which 'protect us against reality, that is, against the claim on our thinking attention which all events and facts arouse by virtue of their existence' (Arendt 1971a: 418, 446; LKPP: 42; see Beiner 1982: 111). By contrast reflective judgement jolts our notions of pre-given meaning, the standards and criteria that we take for granted. In judging reflectively, we attempt to discern the worth of things without recourse to standards 'borrowed from experience' or 'derived from outside' the realm of human affairs (LKPP: 76). Reflective judgement is akin to initiatory action, in this regard, since it is 'a mode in which automatism is broken' (Kateb 1985: 38). In judging reflectively we re-constitute common sense, as it were, by reinventing existing categories or deriving new concepts for making sense of the world we share in common.

\footnotetext{
${ }^{26}$ Whether Arendt actually manages to escape a legislative conception of judgement is contentious. For instance, Hutchings (1996: 95f.) argues that 'Arendt treats the concept of the sensus communis as if it has resolved the problem of the authority of judgement rather than as part of the radical problematising of that authority...[Consequently] judgement is expounded as simple and straightforward, whereas in fact the authority of judgement is ambivalently located in empirical community and transcendental legislation, an ambivalence which represents the separation of the realm of action from the realm of thought'.
} 
Arendt's image of the world-disclosing potential of politics provides a compelling metaphor in terms of which to conceive political reconciliation. As the arena and reference point of politics, a 'world' provides a point of commonality, from which reconciliation might proceed, that does not presuppose community or shared norms beyond a mutual willingness to hear and be heard, to see and be seen. Moreover, in affirming action as both care-for-the-world and agonistic-striving, an ethic of worldliness aspires to hold together the world-delimiting and world-rupturing moments that we earlier attributed to reconciliation, on the one hand, and politics, on the other (see 1.4). To recall, whereas reconciliation turns toward harmony and resolution, politics thrives on contestability and uncertainty. Arendt's ethic of worldliness is ideally suited to formulating a political concept of reconciliation because it shows how the tension between these two moments can be ethical and creative. While a willingness to reconcile (care-for-theworld) opens a space for politics and thus provides an ethical context that mitigates against the risk of politics, the willingness to politicise (agonisticstriving) postpones the moment of positive-affirmative closure that reconciliation inevitably tends toward.

As I show in the following chapter, when conceived in these terms reconciliation is oriented toward disclosing the world in its commonness through an agonistic inter-action. As such, political reconciliation entails, as Aletta Norval (1999: 510) argues it must, 'not an easy bonhomie, but a difficult, restless and unceasing negotiation.' The possibility of transforming a relation of enmity into one of civic friendship depends on the willingness to assume the risk of politics for the sake of its promise. If the risk of politics, in this context, is that the world will continue to be perceived from the radically opposed perspectives determined by a relation of enmity, its promise is that, by engaging in an incessant discourse about the world that lies between them, this world might become more common to former enemies. 


\section{Political Reconciliation}

I began this thesis with two assertions. First, political reconciliation should entail not only a reconciliatory politics but the politicisation of the terms within which reconciliation is enacted. We should affirm reconciliation as an aspiration that sustains politics by framing an encounter between enemies in which they might debate the possibility and terms of their association. Yet, we must also invoke politics to resist the logic of reconciliation, its tendency to bring to a close what should remain open, incomplete, contestable. Second, and following from this, in conceiving reconciliation politically we must reverse the order of our moral thinking. It is a political mistake to presuppose a moral community that must be restored. Instead of positing acknowledgment of truth as the precondition for the wrongdoers' return to community with the wronged, then, political reconciliation begins with the invocation of a "we" that is not yet and proceeds from the faith in its possibility toward a shared understanding of what went before.

In this chapter I show how the foregoing examination of the ethics of toleration, recognition and worldliness lends support to these claims. In 5.1, I restate the challenges that Schmitt's ultra-politics, Locke's limited politics and Taylor's teleological politics present for political reconciliation and the difficulties they lead us into. Moreover, I show how Arendt's ethic of worldliness responds to these challenges and gets us beyond the difficulties. Having drawn together the argument so far, I argue in 5.2 that political reconciliation must be conditioned by an awareness of its own impossibility. While the aspiration to reconcile makes politics possible between former enemies in the present, a final reconciliation is a political impossibility since it would entail overcoming contingency and plurality, which are the enabling conditions for a reconciliatory politics in the first instance. In this sense, reconciliation is a political good only so long as it is not realised. 


\subsection{Beyond realism, toleration, recognition}

The restorative conception of reconciliation begins, as we saw in 1.2, with the presupposition of the wrongdoer's alienation from a moral community. By violating the shared moral standards that bind the members of the community, the wrongdoer places himself outside society. In acknowledging the moral truth of his wrongdoing, the perpetrator initiates a process of reconciliation with those he has wronged. Following remorse, reparation and penance on the part of the wrongdoer and forgiveness on the part of the wronged, reconciliation refers to the restoration of the wrongdoer to the moral community.

I argued that this conception of reconciliation is inadequate for the context of a polity divided by grave state wrongs because it is not political enough. This is so, firstly, because it presupposes community between wrongdoers and wronged rather than recognising this as the contingent outcome of their political inter-action. Second, because it presupposes the continuity of a shared normative order between wrongdoers and wronged, it does not distinguish the political aspect of wrongdoing (its legitimation by existing social relations) from its moral aspect (which takes for granted the equality of persons). Third, it tends to reduce the political to the moral. Rather than acknowledging plurality, it presupposes a publicly accessible normative order that is independent of actually existing communities, according to which political relations should be organised. While the restorative conception of reconciliation captures an important aspect of how we commonly respond to and seek to ameliorate wrongdoing in our moral lives, it would be a mistake to think of the politics of reconciliation in this way because it over-determines the terms within which it would be enacted.

In presupposing community, rather than recognising its fragility, the restorative conception of reconciliation fails to take into account the risk of politics. Schmitt's importance for thinking about political reconciliation, as we saw in 1.3, is that he brings this risk into view by showing how politics is conditioned by the ever-present possibility of the friend-enemy relation. Though Schmitt recognises that moral principles must be universal to be valid, he reminds us that politics always involves a clash between different groups' competing interpretations of moral truth. Thus, Schmitt points out 
that politics always revolves around the terms of inclusion and exclusion. Consequently, whereas the moral turns on the distinction between right and wrong, the distinction of utmost importance in politics is that between friend and enemy. The risk that our political interaction will result in a relation of enmity rather friendship could only be avoided by ceasing to ask ultimate questions about what makes life worthwhile. For it is only because we attach such importance to the frameworks by which we answer these questions that humans are willing to stake their lives in defence of shared values and beliefs. Since political reconciliation is oriented to the constitution of a "we", it cannot avoid but only elide this risk by presupposing community.

It is appropriate, therefore, to take a relation of enmity between rival political groups, rather than a relation of alienation between co-members of a moral community, as the starting point from which to consider the possibility of political reconciliation. Schmitt is important for recognising the tendency for reconciliation to obscure the risk of politics, to depoliticise community by construing its "restoration" in terms of redemption, healing and settlement. However, as I argued in 1.4, although Schmitt's realism reveals the importance of politicising reconciliation, it tends to preclude the possibility of a reconciliatory politics. For, in privileging sovereignty, Schmitt is led to understand plurality as a threat to the political association rather than a condition of its constitution. Moreover, by focusing on the antagonistic conflict between enemies as that which reveals and affirms what is common among group-members, he neglects the importance of the kind of agonistic symbolic conflict between adversaries that has the potential to transform received categories of understanding. Following from this, Schmitt's account of friendship is inadequate because it is derived from a relation of enmity. Such a concept of friendship is too fragile to sustain a reconciliatory politics because it neglects what might be common among group members independent of their relation to outsiders.

In order to articulate a political conception of reconciliation, then, Schmitt's realism must be rejected. I can now restate the critique of Schmitt from an Arendtian perspective and show how her ethic of worldliness answers his challenge. First, by privileging sovereignty, Schmitt makes the age old mistake of wanting to organise politics on the model of rule in order to overcome its risks. We saw that, for Arendt, the risk of politics includes, 
but is not reducible to, the ever-present possibility of the friend-enemy relation. Schmitt's realism is actually anti-political, in Arendt's normative sense, because he substitutes making for acting. He wants to master action from beginning to end rather than accepting the unpredictability of politics as the price of freedom. Against the ideal of sovereignty as a 'solution' to the risk of politics, Arendt proposes the faculties of forgiving and promising, which, as we will see in chapters six \& seven, are central to a reconciliatory politics.

Second, Schmitt neglects the world-disclosing potential of politics by imagining that this emerges only in the confrontation between enemies. Arendt shows us that politics may be reduced to mere talk not only when procedure is substituted for struggle, as in liberalism, but when we are only 'for' or 'against' others rather than 'with' them. When the distinction between friend and enemy becomes the organising principle of political discourse, the plurality of views that we depend on for our common sense of the world is reduced to only two opposed perspectives. This radicalisation of politics desensitises us to the disclosure of difference in action that is the peculiar achievement of politics. By contrast, a politics that attends not only to the conflict between identities but to the differences that exceed them provides the basis from which commonness might be revealed in diversity.

Third, Schmittian friendship cannot sustain a world in common because it does not allow a space for politics between friends. Solidarity against a common enemy provides a feeling of warmth and good will among friends. However, it does not allow a true feeling for the reality and worth of things because it is always determined in opposition to the other. This was demonstrated, for instance, by Memmi's observation that the colonised fail to liberate themselves from colonial domination so long as they continue to define themselves in opposition to the colonisers (see 3.3). By contrast, an Arendtian ideal of friendship is more robust. It lends itself to political reconciliation because it is predicated on our enjoyment of a world in common with others rather than solidarity against a common enemy.

In contrast to Schmitt, we saw that Locke understands plurality to be inherent to political association. Rather than taking plurality as the basis for a struggle over ultimate ends, Locke counsels friendship in the diversity of 
opinions. Locke responds to the risk of political enmity by appealing to antagonists' reciprocal interest in the public good of security. Mutual toleration opens the way for friendship between former enemies even though they may adhere to irreconcilable conceptions of the good. By recognising their common interest in collectively securing their private freedoms, enemies come to see their clash of world-views as irrelevant to their political association. On this account, political reconciliation would mean acknowledging the wrongs of the past as the result of intolerance, the illegitimate and unreasonable resentment of difference and consequent unwillingness to share territory, resources or institutions with different others. As such, political reconciliation would be brought about by restoring the rule of law, increasing democratic accountability and fostering a culture of respect for human rights. While political reconciliation would require more than a modus vivendi, which is the most that Schmitt's realism could furnish, it would resist the stronger ideal of social unity and harmony suggested by an ethic of recognition.

Toleration is an appealing ethic that might animate political reconciliation because it accepts plurality as an unavoidable aspect of political association and because it takes the risk of politics seriously. Yet, as I argued in 2.4, the conception of politics it relies upon is too limited to sustain reconciliation. For, in seeking to mitigate the risk of politics by privatising the conflict between enemies, it tends to deny reconciliation as a legitimate political aspiration. By limiting the legitimate end of politics to the public good of security, Locke conceives human interdependence too narrowly (see 2.1). Moreover, Locke tends to obscure the political nature of the tolerant society's exclusions by establishing the public good of security as a nonpolitical ground on which to establish the rule of law (see 2.4). Finally, because Locke regards politics with fear, he looks to the private realm to realise human freedom and so underestimates the creative potential of politics (see 2.3).

Again, each of these critical points can now be restated and responded to in terms of Arendt's ethic of worldliness. First, the common interest in security is not sufficient to sustain political reconciliation. To be sure, security is a fundamental public good, which can only be established collectively. Moreover, it is necessary to establish security in order to create a 
space for politics. However, it is a mistake to limit politics to guaranteeing security alone. Rather, the importance of security is that it is an enabling condition for politics. So long as people's lives are dominated by fear or the struggle for sheer survival they are not free to engage in an agonistic politics. Political interdependence is based not only on the need for mutual protection but the desire for meaning, for a sense of the reality and worth of things. The possibility of reconciliation depends on this world-disclosing potential of politics.

Second, by appealing to the rule of law to limit the risk of politics, Locke obscures the political foundation of the liberal regime. As such, he tends to write with the prejudice of the philosopher who wants to subordinate will to reason, politics to the law. Locke wants to overcome the partiality of opinion by establishing the public good as the measure of government. On the one hand, his social contract theory suggests that the laws of the polity rest on an agreement on this good among the people. Yet, on the other hand, this agreement is compelled by the force of reason, that is, by each individual's knowledge of the law of nature. To the extent that toleration relies on the latter as an extra-political ground for the public good, however, it obfuscates the political nature of its own exclusions. Reflective judgement, by contrast, politicises the terms of reconciliation because it is based on a potential agreement with others rather than the compulsion of legislative rationality.

Third, because Locke's principal concern in justifying toleration is to ward off the dangers of politics, he presupposes that freedom begins where politics ends. Locke understands political liberty as freedom from politics, non-interference by others in one's private affairs. However, the distrust of politics on which toleration is predicated means that it shies away from an agonistic encounter between adversaries from which a sense of the commonness of the world that lies between them might be revealed. Like Locke, Arendt insists on a clear distinction between public and private. Moreover, she recognises the importance of protecting a private sphere in which individuals may take refuge from the demands of public life. However, whereas for Locke freedom is guaranteed by privacy, for Arendt it is actualised through initiatory action. So long as we remain withdrawn from public life we are deprived of that sense of reality, permanence and 
relationship with others that the space of appearances imparts to human affairs. Following Arendt, the possibility of political reconciliation depends upon the willingness of individuals to assume the risk of politics by acting in concert.

Whereas Locke wants to overcome a relation of enmity by depoliticising identity, Taylor's ethic of recognition suggests that we do so by transforming an antagonistic confrontation into a reciprocal dialogue oriented to a shared understanding. As political attitude or practice, recognition requires that we understand the other in terms of her own values and practices rather than judging her from within our ethnocentric standards. Recognition is embodied in institutions that sustain and preserve particular forms of life deemed inherently valuable by their members and, therefore, essential for their flourishing as human agents. On this account, political reconciliation would require not only that we recognise those wronged as legal persons entitled to equal respect. We would also need to recognise the intrinsic worth of their particular form of life. Through recognising the common humanity and distinct identity of those wronged, their sense of dignity and self-worth might be restored. This is accomplished, for instance, through listening to the voices of survivors, empowering communities through support of culturally-specific institutions, supporting education in their language and history and establishing special corporate rights to ensure the survival of cultural practices.

Conceiving political reconciliation in terms of a struggle for recognition moves beyond the limit of toleration since it invites the risk of politics by making the contest over identity central to the realisation of community between enemies. However, as I argued in 3.4, because recognition relies on an ambiguous account of identity as both relational and essential, it leads us into a dilemma in which, it seems, we must choose between appropriation of or indifference to the other's identity. The demand for recognition tends to reify the distinction between self and other that political reconciliation ought to call into question because it is driven by the ideal of authenticity (see 3.2). Yet it also makes an unwarranted presumption of community between antagonists because it presumes that the struggle for recognition will end in a fusion of horizons (see 3.3). Moreover, recognition always tends towards an anti-political moment in which the non-identity of 
the other is reduced. While political reconciliation must proceed from the terms of self and other that constitute the horizons of meaning within which the violence of the past was perpetrated, I concluded in 3.4, it must forestall the anti-political moment of recognition, which over-determines both the authentic identities from which the struggle for recognition originates and the communal end to which it is oriented.

Once more, I can now restate these criticisms from an Arendtian perspective and demonstrate how worldliness overcomes the difficulties that recognition leads to. First, although Taylor's understanding of the self as embedded within webs of interlocution provides a richer account of human interdependence than is afforded by Locke's tolerant self, the ideal of authenticity means that identity tends to over-determine action. Taylor overestimates the extent to which we are in control of our selves as the authors of our own life stories. Moreover, since it is only by being true to an historical self that we are able to act meaningfully in the world, it is difficult to conceive how we are capable of initiatory action. The possibilities of the present are over-determined by our existing self-understandings. By contrast, Arendt's inversion of the relation between action and identity provides a basis for conceiving how the hope for a new beginning, on which political reconciliation depends, is possible. Arendt's performative conception of the self emphasises how identity emerges from rather than determines action. Moreover, this identity remains contingent and revisable since it does not precede action but only exists so long as it appears to others through our words and deeds. This performative conception of the self is particularly attractive for a theory of political reconciliation since it does not presuppose that collective identification is a necessary precondition for collective action.

Second, although he rightly emphasises the importance of symbolic conflict for constituting community, Taylor elides the frailty and contingency of the 'we' that might emerge from political inter-action by presupposing that a struggle for recognition will end in a fusion of horizons. Whereas an ethic of recognition presupposes that a community will eventually be, according to an ethic of worldliness community is the fragile achievement of action, which exists only so long as it is actualised in the space of appearances. Moreover, the "we" that is disclosed through inter-action is 
contingent because its realisation depends on the willingness of those who constitute it to begin anew, to call the world they share into question. Following Arendt, the end of political reconciliation would not be to define a common identity that could encompass former enemies. Rather, it would be to keep available a space for politics within which they could debate and contest the terms of their political association and the significance of past events for their life in common. Rather than looking to politics to secure a common identity, recognition of the fragility and contingency of community conditions and sustains the space of appearances.

Third, recognition concentrates too much on the 'what' of the other, the qualities and attributes according to which he is the same as 'them' and different from 'us'. The dilemma of recognition emerges because the difference that exceeds identity, the ineffable 'who' of the agent that is revealed in action, is reduced in terms of the categories of identity and otherness. By celebrating the revelatory quality of initiatory action, the disclosure of 'who' the other is through his words and deeds, Arendt invites us to grasp the non-identity of the other that promises to liberate us from the potentially reductive categories of the friend-enemy relation. Moreover, Arendt's account of reflective judgement suggests a political attitude that defers a certain anti-political moment in recognition by seeking to grasp the unprecedentedness and singularity of events and the actions of others. This attentiveness to that difference which exceeds the terms of our existing categories of judgement is fundamental for political reconciliation since it shows a way to resist the reality of the world created by past wrongs.

\subsection{The political (im)possibility of reconciliation}

If reconciliation is to be conceived politically, then, it must take all this into account: that politics is risky because we lack sovereignty over action; that the disclosure of commonness depends upon plurality; that the possibility of friendship depends on our enjoyment of a world in common; that we depend on the presence of others for a sense of reality and meaning; that norms are politically relevant only to the extent that they are based on agreement with others; that freedom is actualised by beginning; that identity emerges from acting in concert; that community is the fragile and contingent achievement 
of politics; that politics is enabled by difference and the deferment of the moment of closure.

Consequently, political reconciliation must be conditioned by an awareness of its own impossibility. This is not simply to say that reconciliation is an ideal that we should strive towards even though political reality must always fall short of it. As Chantal Mouffe (2000: 137) observes, advocates of deliberative democracy tend to present reconciliation in these terms by taking the model of a free, unconstrained communication as a regulative ideal by which to judge and transform actually existing social relations. On this account, the anticipated future of community furnishes an ideal that political reality might approach in an asymptotic relation as we overcome the empirical obstacles that frustrate reconciliation in the present (e.g. see Gutmann \& Thompson 2000). Similarly, the moral community that is presupposed by the restorative conception of reconciliation is not meant to refer to an actually existing political community but rather an idealised image of our social relations by which we make moral sense of our particular dealings with others. Accordingly, we judge the authenticity of attempts at reconciliation in the light of the ideal moral community they would seek to realise.

By contrast, an ethic of worldliness suggests not only the empirical improbability of reconciliation but its political impossibility. For although the aspiration to reconciliation enables a reconciliatory politics in the present, its realisation would undercut the conditions that constitute its possibility. The ideal of reconciliation is self-negating to the extent that it would overcome the plurality that enables a potentially world-disclosing interaction in the first place. As Aletta Norval (1998: 261) argues, since 'full reconciliation depends upon a complete coincidence with the self, it by definition rules out any relation to another which prevents such self completion'. In other words, it would bring to a close the incessant discourse by which we humanise the world that lies between us. Reconciliation necessarily presupposes as its telos a community that is not yet. Yet, if reconciliation is to be conceived politically, this end must be recognised, as Chantal Mouffe (2000: 137) suggests, as 'a good that exists as good only as long as it cannot be reached.' 
On this account, the anticipation of community does not furnish a universal ideal in terms of which a reconciliatory politics in the present might be ordered. Rather, faith in the possibility of reconciliation and an awareness of the frailty and contingency of the anticipated community establishes a context in which it is possible to confront one's former antagonist as political adversary. Yet it is only so long as the end of reconciliation remains as an open horizon that it sustains politics. When reconciliation is animated by the desire to enact a final settlement or closure, by contrast, it becomes anti-political. Against this tendency to overdetermine the terms within which reconciliation is enacted by hypostatising community as a regulative ideal, we must fall back on politics itself. Politicising the terms of reconciliation conditions an awareness of its risks, the recognition that there is no inevitability to community but that it is sustained only by the will to live together in speech and action.

Political reconciliation would thus involve a fractious inter-action oriented to disclosing the commonness of the world. Through a fragile holding together of the world-delimiting and world-rupturing moments of this interaction, it would enclose antagonists within a shared horizon while affirming their freedom to contest the terms within which this horizon is constituted. In this context, past wrongs would appear as an attack on human plurality driven by resentment of the frustrations of the will that occur when we act together with others. Genocide is the extreme manifestation of this desire to overcome the haphazardness of politics by violently remaking the world according to the logic of an idea. Against such a radical negation of plurality, the promise of reconciliation depends on holding open a space for politics by recognising the other as co-builder of a common world; i.e. as political adversary rather than antagonist.

As such, political reconciliation does not presuppose a prior community that must be restored between wrongdoers and wronged. While it is animated by the faith that the commonness of the world that lies between adversaries might be revealed through their political interaction, this is recognised as a possibility rather than an inevitability. Agreement on moral norms is not required in order to initiate a process of reconciliation. Rather, political reconciliation presupposes only the will to live together in the mode of acting and speaking. Though antagonists may disagree radically 
about the significance and moral meaning of past events for their life in common, they need only acknowledge that they are talking about the same events in order to initiate political reconciliation. For the faith of political reconciliation is that, by engaging in an incessant discourse about the world that lies between former enemies, this world might appear more common to them.

Acknowledging the impossibility of reconciliation suggests further the need to reconsider the temporal sequence of political reconciliation. For, if the moral norms by which we ought to order our present social relations cannot be derived from the anticipation of an ideal community, then the acknowledgment of moral truth cannot be a precondition for reconciliation. Rather, the anticipation of community conditions the possibility that a shared understanding of the significance of past wrongs will emerge from our political interaction. In certain circumstances, as Bert van Roermund (2001: 179) suggests, 'reconciliation is what makes the revelation of truth possible.' The joint commitment to realising a community that is 'not yet' establishes a space for politics within which the revelation of truth is possible.

Consequently, it is a political mistake to employ our ordinary moral intuitions about the order of reconciliation in the context of a deeply divided polity. For shared norms to be politically relevant they cannot be derived from an absolute ideal but depend on the relative agreements of citizens. In the absence of such agreement, an ideal moral community cannot be invoked as the basis from which the moral truth of the past can be acknowledged. For in politics there is good reason to be suspicious of the ideal of community since it is in the name of this ideal that oppression is legitimated. Instead of proceeding through acknowledgement, remorse, atonement, forgiveness towards restoring the ideal of community, then, political reconciliation begins with the invocation of a "we" that is not-yet, which establishes a space for politics in the present. This space is sustained by a willingness to forgive, which in turn invites those implicated in wrongdoing into political association with those wronged. The acceptance of political responsibility draws wrongdoers and wronged into a politics of remembrance according to which former antagonists might recognise each other as adversaries. By contesting the significance of the past for their shared association, the commonness of the world might be disclosed. 
As such, political reconciliation is sustained by the hope that the present will be remembered as the moment in which an anticipated community originated. Yet, it must also be conditioned by an awareness of the risk of politics and its own impossibility so that the tendency to overdetermine the terms within which it is enacted can be resisted. Drawing on the Arendtian account of the political developed in chapter four, then, I trace political reconciliation, in the second half of this thesis, through the sequence of constitution, forgiveness, responsibility and remembrance. In each chapter, I attempt to reveal how political reconciliation entails holding together its world-delimiting and world-rupturing moments and to elucidate the risks that must be acknowledged at each step of the way. 


\section{Constitution}

If we are to formulate a political conception of reconciliation we ought to conceive it in terms of revolution rather than restoration. As such, reconciliation does not begin with the collective remembrance of a prior state of harmony in terms of which our present alienation might be understood. Rather it begins with the invocation of a "we" (that exists only as a potentiality) as the basis of a new political order. Political reconciliation is thus initiated with the constitution of a space for politics, which makes possible a collective reckoning with the past. In this context, constitution entails both beginning and promising. On the one hand, it requires that we conceive the present as a point of origin, which might appear in retrospect as the moment in which 'the people' first appeared on the political scene. On the other, it requires that former enemies promise 'never again' in order to condition the possibility of community in the future. By constitution, then, I do not refer primarily to issues of jurisdiction and state organisation. Rather, I am concerned, more specifically, with the performative constitution of a "we" through collective action and the constitution of a space for a reconciliatory politics in which the appearance of this "we" is an everpresent possibility.

This perspective reveals the constitutional politics of reconciliation to be inextricably linked to questions of time and identity. I begin this chapter by arguing that if reconciliation is to be political it must also be historical. Political reconciliation cannot transcend the conflicts of the past by appealing to an ultimate end. Rather, it must be enacted in the gap between past and future, between the memory of offence and anticipation of community. In $6.2, \mathrm{I}$ argue that the hope of reconciliation derives from understanding the present as a possible new beginning. Constitution is world-rupturing to the extent that it enacts a radical break with the past through the act of founding the polity anew. However, as I show in 6.3 , if this beginning is to succeed it 
requires that former enemies establish shared expectations through promising. This is the world-delimiting moment of constitution. Yet, the institutionalisation of promises within a legal constitution tends to overdetermine the terms within which a reconciliatory politics might be enacted since it presupposes that community already is rather than recognising it as not yet. In 6.4, I look to Australia and South Africa to illustrate how a legal constitution in this way both facilitates and frustrates the ethical constitution of a "we" that political reconciliation seeks to realise.

\subsection{Between past and future}

The Christian faith in reconciliation is inseparable from the moral ideal, articulated by Jesus in the sermon on the mount, that we should love our enemies (Luke 6: 31-37). Yet, as Arendt shows in her intriguing dissertation on St Augustine, there is a paradox inherent in the ideal of loving one's neighbour as one's self, given the self-denying nature of Christian love. Since right love of God (caritas) involves relinquishing one's wrong love of the world (cupiditas), Arendt wonders how the individual who is 'isolated from all things mundane' in God's presence can be 'at all interested in his neighbour' (LSA: 7). For to love one's neighbour as oneself is to love him not in terms of his singular, worldly existence but by virtue of the universal quality of his createdness. The other's will toward me as friend or enemy is relevant only in the situation of worldly interdependence. In the presence of God his particular relation to me becomes irrelevant. To love one's neighbour in caritas is, thus, to love the source of his being rather than the particular person who appears before me. Yet this seems an inhumane love, which contradicts our mundane experience of love as both partial toward and dependent on its object.

For Augustine, the human experience of alienation is closely associated with our existence as temporal beings. To exist in the world is to be subject to time, to be always no more and not yet. By contrast, God always is and, as such, stands outside time. The wish to be reconciled with God, in this context, reflects the human aspiration to overcome the alienation of temporal existence by 'returning' to eternity. It is this anticipation of an absolute future - the re-presentation of our absolute past (before the Fall) as a 
radical future possibility (through Grace) - that gives rise to the paradox of neighbourly love. For the anticipated future of eternal life in God serves as a point of reference that lies outside the world and regulates 'all things inside the world as well as...the relationships by which they are interconnected' (LSA: 37). A tension is thus established between the vertical reconciliation between individual and God and the horizontal reconciliation among neighbours in the world. Since the world is used as a means toward realising this highest good rather than enjoyed for its own sake, it 'loses its independent meaningfulness and thus ceases to tempt man' (LSA: 33). Consequently, all bonds between man and world are undone. Reconciliation between neighbours is predicated on a universal love that renders all distinctions between persons (including that between friend and enemy) irrelevant. But this seems to require ordering human affairs from a timeless standpoint such that community with the other is countenanced in terms too abstract to realise any meaningful "we" in the world.

Following Augustine, Arendt argues that time itself is unthinkable without a creature through whom time passes, a creature who is 'inserted' in time in such a way that it is broken up into the tenses of past, present and future (LSA: 55). As the only animal that knows it was born and that it will die, the human agent experiences time as a stretching out between its first inexplicable appearance in the world and its ultimate disappearance from it (LM I: 20; HC: 97; LSA: 55). In other words, we actualise temporality through remembrance and anticipation. ${ }^{1}$ This is the meaning of Faulkner's famous claim that 'the past is never dead, it is not even past' (BPF: 10). For the achievement of memory is to re-present the past, to make present for our thinking attention what is no-longer (LM I: 86). Similarly, the future is actualised by our hopes and fears as the 'threatening or fulfilling 'not yet' of the present' (LSA: 13). We exist, then, in the broken middle of time, the 'gap between past and future' (BPF: 7f.). In our present situation we anticipate the future with fear or hope based on remembrance of what was and the knowledge that what has been could be again. Conversely, we remember the

\footnotetext{
${ }^{1}$ As such, time is not reducible to the intervals by which we measure it. Rather, it is because we reckon with time through remembrance and anticipation that we are driven to measure it. Our preoccupation with the world leads us to reckon with time in such a way that we can waste time or have the time, there can be a time to do this, a right time and a wrong time. Thus, human existence becomes meaningful, in temporal terms, through public interaction by which time is 'woven in common' with others (Ricoeur 1981: 169-171).
} 
past with regret or nostalgia in terms of our imaginative anticipation of the possibilities that the future holds (LSA: 48$){ }^{2}$

Time, as it is humanly experienced, is therefore distinct both from the non-time of eternity (the absolute of temporality) and the time of nature (the everlasting cycles of life). Expectation of death and remembrance of birth make humans aware of their finitude in contrast to the infinity of a God who has no beginning or end but stands outside time (OR: 206). Against the dispersion of human existence into past, present and future, eternity is conceived as a standing still of time in which the presence of the whole of time is manifest in an enduring Now (LSA: 53). We experience alienation from God because we are able to imagine eternity when we retreat from the world to think. Yet we remain aware of our own finitude due to our acting and suffering in the world. ${ }^{3}$

On the other hand, the human experience of time is in contrast to the time of nature because it follows a linear rather than a cyclical course. In contrast to the endless cycles of nature, which proceed along their course indifferent to human affairs, the stretching out of time through remembrance and anticipation means that events, actions, biographies, epochs are thought of as having a beginning, middle and an end. As animals we are subject to the cycles of nature and to those necessities required to sustain life. Yet, we also transcend nature in our historical existence as worldly creatures who seek to establish a sense of permanence in our affairs through work and remembrance. We experience alienation from Nature because, although we are subject to the never ending rhythms of life, we have a sense of the irrevocable succession of events, of time "marching on." This ordering of experience in terms of a rectilinear time concept has the potential to redeem human existence from the futility of nature's endless repetition.

\footnotetext{
${ }^{2}$ At least, this is what I make of Arendt's interpretation of Kafka's parable of "He" who struggles with two antagonists. One 'presses him from behind, from the origin. The second blocks the road ahead. He gives battle to both' while each assists him in his struggle against the other (Kafka in BPF: 7). It is only because He seeks to stand his ground that the flow of indifferent time becomes broken in the middle.

${ }^{3}$ As Ricoeur (1983: 62 - emphasis in original) writes: 'The question of time is raised, or rather time is raised as a question, because man is the only being which knows that it is "mortal," because man alone thinks and thinks what is eternal. Hannah Arendt never departed from this basic worldview - which is both pre-Socratic and Hebraic - that eternity is what we think, but that it is as "mortals" that we think it.'
} 
Yet it also threatens to empty experience of its immanent meaning by explaining our doing and suffering in relation to an ultimate end. Hope for reconciliation with God underpins a teleological conception of time as building towards a unique and shattering climax, a final judgement at the end of history, which will restore believers to their place in the eternal kingdom of God. Sheldon Wolin (1961: 124f.) argues that this Christian conception of time, which displaced the classical conception of cyclical time, had enormous political implications. Christianity transformed human beings' relation to the future with the promise of redemption. This enabled men to anticipate the unfolding of time with hope rather than the dread that had been characteristic of the classical mind. ${ }^{4}$ But this new time-dimension was anti-political, according to Wolin (1961: 124), because 'political society was implicated in a series of historical events heading towards a final consummation which would mark the end of politics.' Consequently, politics was no longer looked on as an opportunity for glory but as a weary necessity of worldly existence. Moreover, the quest for the ideal polity was condemned as irreverent and proud ambition animated by the desire to establish Man's independence from God.

The manner in which we reckon with time, then, not only opens the possibility of meaning in human affairs but may undermine the conditions according to which we invest the world with meaning. To some extent, Arendt concurs with Wolin's conclusions about the anti-political nature of the Christian concept of time (HC: 21, 54-55, 120). The ideal of an absolute future by which we make sense of the present leads us to take an instrumental attitude to the world, according to which events and actions are explained as means toward this ultimate end. Consequently, human affairs are divested of any intrinsic worth so that 'this world is for the

\footnotetext{
${ }^{4}$ The Greeks tended to understand time in terms of cycles which closely resembled nature's seasons of growth and decay. Consequently, heroic action (being able to answer the demands of the moment with excellence, with the hope of being immortalised by the poets) and founding a polis (which could withstand the destructive impact of time) were fundamental political aspirations. However, for the Christian, 'the classical notion of an eternally recurrent cycle governing human affairs, a rhythm which began in hope and ended in despair, seemed a mockery to both God and man' (Wolin 1961: 124)

${ }^{5}$ However, it is to Augustine that she frequently attributes the fundamental political insight that human freedom is inherent in our capacity to begin (e.g. HC: 177). Moreover, she observes that 'only under the condition of a rectilinear time concept are such phenomena as novelty, uniqueness of events, and the like conceivable at all' (OR: 27).
} 
faithful...what the desert was for the people of Israel - they live not in houses but in tents' (Augustine in LSA: 19). Yet, asks Arendt in her dissertation, 'Would it not be better to love the world in cupiditas and be at home? Why should we make a desert out of the world?' (LSA: 19). Indeed, as we saw in 4.1, it is precisely such love of the world that Arendt advocates in her later work, when she turns to politics to redeem human existence from the meaninglessness generated by such an instrumental mentality in public life.

In this context, Arendt affirms the striving for a worldly immortality against the yearning for eternity. Philosophy and the life of contemplation begin from wonder at the eternal, a sublime which can only be experienced outside the company of others in the solitude of thought. By contrast, political life is animated by the desire of actors to win recognition from their peers and to establish a lasting remembrance of their words and deeds (HC: 17-21). As Paul Ricoeur (1983: 62) observes, immortality is 'what we attempt to confer upon ourselves in order to endure our mortal condition'. That every life can eventually be told as a story that begins with birth and ends in death is the 'pre-political and pre-historical condition of history, the great story without beginning or end' (HC: 184). History presupposes a common world that precedes and will succeed the comings and goings of generations (HC: 97). The achievement of the polity is that it makes possible an organised remembrance by which to overcome the frailty of action. The political enterprise of distinguishing ourselves through action and of founding and preserving a world in common is, in this respect, the 'highest attempt to "immortalise" ourselves. From this attempt springs both the greatness and the illusion of the whole human enterprise' (Ricoeur 1983: 62).

Against the temptation to conceive the time of reconciliation in relation to a sacred origin or end of history in which our alienation is overcome once and for all, this suggests that a mundane reconciliation depends upon constituting a space for politics in the present within which conflicting memories and expectations can be brought to bear on each other. Politics is concerned with men in their temporal existence and in their neighbourly relations to each other as friends and enemies. As Arendt observes, morality may require us to imagine the 'earth as the homeland of all mankind' and to presuppose 'one unwritten law, eternal and valid for all' 
(MDT: 81). Politics, however, does not deal with 'Man' in the abstract (as autonomous, rational being, subject to the laws he gives to himself) but with 'men' in their plurality (as earthbound creatures who belong to different communities and are 'heirs to many pasts') (MDT: 81; LKPP: 27). Following from this, if reconciliation is to be political, it depends on citizens discovering good grounds to want to share a polity at all with their historical enemy or oppressor. This requires not that we transcend our relation to our neighbour as enemy but that we transform it into one of civic friendship.

As we shall see, what animates political reconciliation, then, is not the anticipation of community as absolute end according to which we ought to regulate our present relations. Rather, it is the will that the present be remembered by a possible future community as the moment in which it originated. In this way, the constitution of a space for politics makes possible a future collective remembrance. Or, as Bert van Roermund (2002) writes, in a different context, it makes available 'a past to look forward to'. Reconciliation necessarily anticipates a future community. However, insofar as it is political, this is conditioned by an awareness of the frailty and contingency of the "we" it seeks to realise. It is this anticipated remembrance that holds together (in the present) the world-rupturing and worlddelimiting aspects of constitution, which coincide with the exhilaration of beginning and the concern to establish a lasting institution through promising (OR: 223).

\subsection{Beginning}

Political reconciliation presupposes a revolutionary moment. As Bruce Ackerman (1992: 5) observes, revolutionaries divide history into a Before and a Now: 'Before, there was something deeply wrong with the way people thought and acted. Now, we have a chance to make a "new beginning" by freeing ourselves from these blinders.' As such, political reconciliation is predicated on the 'recasting of the present as a point of origin' (Christodoulidis 2000: 199 - emphasis in original). It is frequently observed that political reconciliation must be both retrospective (in coming to terms with the past) and prospective (in bringing about social harmony) and, therefore, must involve striking a balance between the competing demands 
of these temporal orientations. For instance, past-oriented concerns with punishing human rights violators must be considered in the light of futureoriented concerns with establishing democratic institutions (see Ackerman 1992: 70f.; Teitel 2000: 191-211; Villa-Vicencio \& Verwoerd 2000).

Yet, understanding the present as a point of origin entails a reckoning with time that is more subtle and complex than is immediately suggested by the metaphor of 'looking back' while 'reaching forward'. This is because political reconciliation refers to a future anterior, an imagined 'not yet' that is 'brought into the present to become constitutive of the experience of the present' (Christodoulidis 2000: 198). From the perspective of this imagined common future, the experience of the present is interpreted as a possible new beginning, as the moment in which reconciliation 'will have been' initiated. To perceive the present from the perspective of this future anterior is to recognise its contingency since what 'has been' could always 'have been otherwise'. Following Christodoulidis (2000: 198), this 'temporal modality' of political reconciliation is 'to be celebrated' because it 'imports an awareness that keeps community both attuned to the aspiration of being-in-common and aware of its vulnerability.' It is this awareness that politicises reconciliation since it interprets the present in relation to a contingent historical possibility rather than an absolute end. ${ }^{6}$

But this temporal modality also requires that we reckon with an absolute that is neither anticipated nor remembered but, rather, confronts us in the present in the act of beginning. The foundation of a new polity is, for Arendt, as it was for the Romans, the political act par excellence. This is because it exemplifies the human potentiality to do the unprecedented. Beginning is exhilarating because it is the actualisation of freedom in action. Yet the act of foundation is also perplexing because it confronts us with the arbitrariness inherent in every beginning. We accord coherence to human experience by telling a story of how we came to be where we are and by projecting this story into the future in terms of what we are questing after. In the case of the beginning, however, we are confronted with 'an unconnected,

6 The "we" that animates political reconciliation thus closely resembles that 'indeterminate consensus' Arendt calls the sensus communis (Burns 1987: 177; see 4.3). 
new event breaking into the sequence of historical time' (OR: 205).7 It is this arbitrary aspect of every beginning that makes it so difficult to be pleased with human freedom. Consequently, when confronted with the new we are driven to try justify it in terms of what came before.

The riddle, for those who wish to found a new social order, then, is 'how to restart time within an inexorable time continuum' (LM: 214). Since political reconciliation is impelled by the hope of establishing such a new beginning, it is self-consciously enacted in the gap between past and future. This transitional moment between the no-more of enmity and the not-yet of community resembles the legendary 'hiatus between disaster and salvation' that is described in the great foundation myths of Western society: the wanderings of the Israeli tribes and the adventures of Anaeis. As Arendt discusses, both the Romans and Hebrews conceived their past in terms of 'a story whose beginning could be known and dated' (LM II: 203). Moreover, in both myths there is a period of transition between the liberation from oppression and the realisation of political freedom through the foundation of a polity. The importance of these myths for modernity, according to Arendt, is that they show how human beings have sought to come to terms with the perplexities of beginning (OR: 205). The revolutionaries of the eighteenthcentury turned to these myths in order to understand and justify what they were doing. As Arendt discusses, these revolutionaries were peculiarly modern in their rejection of traditional authority and their faith in the human capacity to invent new forms of government and community that could be rationally justified. Yet, when confronted by the contingency of the founding act, they were led to 'renege on the very experience of freedom and novelty' by construing what they were doing in terms of restoration, an improved restatement of the principles on which Rome was founded (LM II: 210; OR: 210).

Since political reconciliation must also proceed from an understanding of the present as a point of origin, it is similarly initiated by constitution. In its political sense, constitution refers to the founding act by which a space for

\footnotetext{
${ }^{7}$ Because it is unprecedented, it is as though the revolutionary act came out of nowhere and, as such, it seems to have 'nothing...to hold onto' (LM II: 208). In the revolutionary moment, it is 'as though the beginner had abolished the sequence of temporality itself, or as though the actors were thrown out of the temporal order and its continuity' (OR: 206).
} 
politics is established. According to Arendt, this space 'comes into being wherever men are together in the manner of speech and action' and so 'precedes all formal constitution of the public realm' (HC: 199). Yet, because its existence ultimately depends on its actualisation through performative action it quickly disappears when citizens withdraw from public life (HC: 200). In its legal sense, constitution refers to the fundamental law of the polity that is laid down in the founding act. The formal organisation of the public realm according to legal principles provide a measure of continuity and stability that the space of appearances would otherwise lack (OT: 463). In its third ethical sense, constitution refers to the emergence of a "we" as an 'identifiable entity' in the act of foundation (LM II: 201). As Arendt observes, a "we" arises wherever people come together to act and speak in public and it may take many different forms. Because this identity emerges from collective action, it never simply is but is always in the mode of becoming. Nevertheless, 'no matter how this "We" is first experienced and articulated, it seems that it always needs a beginning, and nothing seems so shrouded in darkness and mystery as that "In the beginning"' (LM II: 202).

Constitution thus refers to the complex inter-relation between politics (democratic will), law (constitutional reason) and ethics (the identity of the people), according to which constitution of a "we" emerges from the articulation of law and politics (Christodoulidis 2001b: 115). Fundamentally, then, the act of constitution requires holding together the apparently 'irreconcilable and even contradictory' logics of performing and legislating: on the one hand an 'exhilarating awareness of the human capacity of beginning'; on the other hand, a 'grave concern' with establishing an enduring regime (OR: 223). For revolutionaries, the legitimacy of the founding act does not derive from tradition but the will of the demos in the present. Yet, it is in the name of the present revolutionary will that they would bind the will of future actors according to the rational principles laid down in a legal constitution. The founding principles become the higher source of law from which the authority of future positive law should be derived (OR: 160). The act of foundation, in which the revolutionaries actualise their freedom to begin, thus, paradoxically, seems to deny this same freedom to future generations for the sake of the stability of the political association (OR: 232f.). 
In temporal terms, this paradoxical articulation of performance and legislation emerges in the fact 'those who would get together to constitute a new government are themselves unconstitutional, that is, they have no authority to do what they set out to achieve' (OR: 183-184). As Derrida (1986: 10) makes clear, it is only in retrospect that they might be understood as founders of law; in the act of foundation they are outlaws since the democratic will they purport to represent is not yet legally constituted. ${ }^{8}$ In the revolutionary moment, the will of the people lacks an institutional framework in terms of which it may be re-presented as such. The ethical constitution of a "we" emerges from this articulation of action and institution. Indeed the "we" of the people is invoked in fundamentally different ways in the performative and legislative moments of constitution. Whereas politics brings a "we" to presence through performative action, law re-presents this "we" by institutionalising it. While politics is enabled by invoking a "we" as an (under-determined) potentiality", law overdetermines this "we" since it must re-present community as already existing in order to establish its legitimacy (see Christodoulidis 2001b).

Nevertheless, Arendt argues that if we are to recover the 'lost treasure' of the revolutionary tradition, we must attempt to think together and combine meaningfully 'what our present political vocabulary presents to us in terms of opposition and contradiction' (OR: 224). For, she insists, concern for stability and the spirit of the new were 'not mutually exclusive opposites' in the experience of revolution 'but two sides of the same event' (OR: 223). For the American revolutionaries, it was a matter of course that they needed

\footnotetext{
${ }^{8}$ In his commentary on the American Declaration of Independence, Derrida (1986: 10) writes: "The "we" of the declaration speaks "in the name of the people." But this people does not yet exist. They do not exist as an entity, it does not exist, before this declaration, not as such. If it gives birth to itself, as free and independent subject, as possible signer, this can hold only in the act of the signature. The signature invents the signer. The signer can only authorise him- or herself to sign once he or she has come to the end, if one can say this, of his or her own signature, in a sort of fabulous retroactivity'.
}

${ }^{9}$ As Paul Connerton (1989: 59) writes: 'Through the utterance of the 'we' a basic disposition is given definitive form, is constituted among the members of the liturgical community. The community is initiated when pronouns of solidarity are repeatedly pronounced. In pronouncing the 'we' the participants meet not only in an externally definable space but in a kind of ideal space determined by their speech acts. Their speech does not describe what such a community might look like, nor does it express a community constituted before and apart from it; performative utterances are as it were the place in which the community is constituted and recalls to itself the fact of constitution.' 
a constitution to preserve the space of appearances they had brought into being in the act of foundation. Having succeeded in the first task of founding a body politic, the second task of the revolution was to 'assure the survival of the spirit out of which the act of foundation sprang' (OR: 126). This depended on ensuring the opportunity for "public happiness" by constituting a space in which freedom could appear.

Yet, Arendt suggests, it was the 'Constitution itself' that eventually 'cheated' the Americans of this 'their proudest possession'; the practice of public freedom. For they came to interpret 'happiness' in terms of the private freedoms the constitution secured - rather than the participation in government it enabled - and so forgot the joys of initiatory action (OR: 239). If the French revolution ended in Terror because it located the authority of law in an unpredictable revolutionary will, the American revolution ultimately failed because no space was reserved within the stable republic it established 'for the exercise of precisely those qualities which had been instrumental in building it' (OR: 232).

Arendt's attempt to recover the treasure of the revolutionary tradition by combining the spirit of the new with a concern for stability thus depends on divesting the latter of its legislative moment and re-conceiving it terms of a promise that is intended to preserve the memory of beginning. It is in this context that she develops a conception of authority as augmentation, which involves a binding back to the beginning. Rather than looking to an Absolute that transcends the realm of politics (such as a mythical origin or end) to legitimate the founding law of the polity we should look to the founding act itself. For, she suggests, it is 'futile to search for an absolute to break the vicious cycle in which all beginning is inevitably caught, because this 'absolute' lies in the very act of beginning itself' (OR: 204).10

In this context, she suggests that the 'political genius' of the American people (i.e. before they lost the treasure of the revolution) derived from their

\footnotetext{
${ }^{10}$ As Kimberly Hutchings (1996: 98-99) observes: 'Arendt wants to keep politics from being law governed. In The Human Condition, this results in political action being characterised as a kind of pure spontaneity; an arbitrary and purposeless process which is matched by the arbitrary violence of the legislator, and only recouped by the judgement of the storyteller. In On Revolution, this results in a recourse to judgement, as opposed to law, as the standard for legislation and political action more generally.'
} 
'extraordinary capacity...to look on yesterday with the eyes of tomorrow' (OR: 198). The stability of the polity was derived their willingness to bind themselves back to a contingent historical beginning. The authority of the legal constitution depended on its being taken as a common reference point for action. Consequently, Arendt suggests, rather than denying future generations the freedom to act it bestowed a 'communicative legacy' that might inspire future action. ${ }^{11}$ For the legitimacy of political action depended on the extent to which it would increase and enlarge the principle of public freedom as enacted in the foundation of the polity (BPF: 122; OR: 201-202). ${ }^{12}$ I am not sure that Arendt succeeds in combining, let alone reconciling, the contending logics of law and politics with this account of authority. ${ }^{13}$ However, as we shall see, it provides a suggestive basis for considering the role that promising plays in sustaining a reconciliatory politics.

\footnotetext{
11 The term communicative legacy is Steve Buckler's (2001: 296). I will consider the significance of this concept for political reconciliation further in 9.3 .

12 As Waldron (2000: 213) points out, this does not mean treating the constitution as 'sacrosanct and beyond change; but it means treating it as the object of change and augmentation, rather than simply purporting to begin again every time we suppose ourselves to have accumulated more wisdom than our ancestors'. In binding future generations by constituting the fundamental law of the polity, we 'want our successors to maintain arrangements that all parties can continue to respect and regard as acceptable' (Thompson 2002: 21). This means that our posterity-binding treaties may be changed and renegotiated in the light of changing circumstances and understandings of what justice requires. As such, a constitution is 'something that evolves, changes its meaning, comes to an end, or is reborn, as the relations between communities develop and conditions and ideas of acceptability change' (Thompson 2002: 202).

13 Honig (1991: 106) and Keenan (1994: 319) both suggest that it is not possible to separate the performative moment of the political from the violence of institutions. For instance, Keenan (1994: 316) argues that 'The realm of freedom - seen as a logic of indeterminacy, openness, plurality, and the possibility of new beginnings - is inevitably compromised in the attempt to found it, even as some such foundation is necessary for its survival...As a result of this paradoxical relation of freedom and foundation, the loss of the "political"...that Arendt regularly laments is a loss that cannot fail to happen'. Yet, since my concern is with the ethical constitution of a "we" through performative action, I want to resist Keenan's conclusion that violence is an ineradicable aspect of the political rather than inherent to an institutional logic that is other to it. With Arendt, I want to maintain an ethical distinction between violence and the political in order to invoke politics against the institutional logic of closure that would undermine the possibility of reconciliation.
} 


\subsection{Promising "never again"}

Political reconciliation is predicated on the promise nunca más or "never again". This was the title, for instance, of the report of the truth commission established in Argentina to investigate the "disappearance" of 10,000 - 30,000 people by successive military juntas between 1976 and $1983 .{ }^{14}$ The promise "never again" locates the possibility of community between former enemies in their present intention to prevent the recurrence of wrongdoing. In this context, the ethical constitution of a "we" depends, as van Roermund (2002) suggests, on prolonging the present moment in which this intention is expressed in order to avoid either a preoccupation with the past (that threatens to overwhelm the future) or a preoccupation with the future (that too easily forgets the past)..$^{15}$

If beginning has the potential to disclose a "we" in the moment of its performance, promising conditions the possibility that this "we" might be brought to presence in the future. There is 'an element of the world-building capacity of man in the human faculty of making and keeping promises', Arendt insists, because it is animated not so much by a concern with ourselves and our own time but with that of those who will succeed us (OR: 175).16 The achievement of promising is that it establishes a 'limited independence' of our present actions 'from the incalculability of the future' (HC: 245). By establishing shared expectations, promising reduces the radical contingency of the future so that we are able to make plans and form projects. It provides a partial remedy against the predicament of unpredictability by establishing certain 'guideposts of reliability' or 'isolated islands of certainty in an ocean of uncertainty' (HC: 244; 224). In contrast to the ideal of sovereignty, the faculty for promising presupposes the presence

\footnotetext{
14 Since its publication, a digest of the report has become one of the best-selling books in Argentina's history (Hayner 2001: 33-34).

15 As Mario Di Paolantonio (1997: 456) observes, to promise "never again" is to make a promise about a future that can never arrive. As such, it is a promise that can never be fulfilled.

16 '...binding and promising, combining and covenanting and the means by which power is kept in existence, where and when men succeed in keeping intact the power which sprang up between them during the course of any particular act or deed, they are already in the process of foundation, of constituting a stable worldly structure, to house, as it were, their combined power of action' (OR: 175).
} 
of others since 'no one can feel bound by a promise he makes to himself' (HC: 237). Yet, it can only provide a partial remedy against the risk of action because, as Alan Keenan (1994: 317) puts it, 'a promise, like any agreement, is at best a point of conjecture, a site at which conflicting goals, intentions, forces, and projects find a common expression or formulation but never an identity of meaning. ${ }^{\prime 17}$

As social contract theory attests, the capacity to make and keep promises is fundamental for securing the individual rights of who would enter into political society together. Arendt understands this role of a constitution in securing the private freedom of citizens to be, not the sole end of government, but an enabling condition for the exercise of political freedom (OR: 218). Far from being a natural attribute of individuals, equality is an artificial achievement of the political association, which establishes an 'equality of unequals' for the limited purpose of enabling politics between them (HC: 215). 'We are not born equal' but become so 'as members of a group on the strength of our decision to guarantee ourselves mutually equal rights' (OT: 301). As the plight of stateless people demonstrates, human rights acquire a concrete reality only to the extent that they are institutionalised and guaranteed by the political association (OT: 297; OR: 149).18 The constitutional guarantee of rights establishes civility by assigning public roles to private individuals. It provides 'channels of communication' between citizens by attributing to them a legal 'persona' (OT: 465; OR: 106109). The conventions and roles established by the law in this way depersonalise action in order to preserve the fragile inter-space of the world (Kateb 1984: 12). ${ }^{19}$

\footnotetext{
17 The context of this sentence in Keenan's critique suggests that he is making this point against Arendt, whereas this seems to me a fundamentally Arendtian insight.

${ }^{18}$ The predicament of the rightless is not that they lack equality before the law but that 'no law exists for them...If a human being loses his political status, he should, according to the implications of the inborn and inalienable rights of man, come under exactly the situation for which the declarations of such general rights provided. Actually the opposite is the case. It seems that a man who is nothing but a man has lost the very qualities which make it possible for other people to treat him as a fellow-man' (OT: 296, 300).

${ }^{19}$ In the theatrical metaphor borrowed by law, the civic persona or mask the actor adopts enables the truth of his opinion to resonate by distancing his private self from public act. By mediating action in this way, the roles and conventions established by law prevent conflict between political adversaries from degenerating into a relation of enmity (Villa 1999: 139, 123).
} 
As such, promising helps to constitute and preserve a 'space where freedom as virtuosity can appear' (OR: 175). Due to its frailties, action alone is insufficient to sustain a space for politics through time. Rather, it is the force of promise that establishes a measure of stability in human affairs and so makes possible an organised remembrance, which conditions the possibility of community in the future. In order to be actualised as a tangible reality, freedom must be 'spatially limited' (OR: 275). Politics is always transacted within a complicated framework of laws and institutions that are constituted through promising (BPF: 164). ${ }^{20}$ 'The laws hedge in each new beginning and at the same time assure its freedom of movement, the potentiality of something entirely new and unpredictable' (OT: 465). Without the common reference points that such limits provide, public action and speech would be incoherent. In this sense, the 'boundaries of positive laws are for the political existence of man what memory is for his historical existence: they guarantee the pre-existence of a common world' (OT: 465). Laws and covenants establish a continuity that transcends the life span of each generation. They provide a context within which action can appear meaningful by providing a stable structure to house the movement of action. In reducing the contingency of the future, a legal constitution thus not only forecloses certain options but 'makes available possibilities which would otherwise lie beyond reach' (Holmes 1988b: 226). ${ }^{21}$

Yet, despite her celebration of promising as a faculty inherent to action that mitigates the risk of unpredictability without reducing its performative quality, Arendt suggests (in her reflections on revolution) that promising may be insufficient to assure the perpetuity of a political association. If the legal constitution is to become the 'higher law' of the polity, 'authoritative and valid for all' both now and in the future, it seems it must derive its authority from a source that transcends politics (OR: 182). The fundamental

\footnotetext{
20 'Just as the inhabitants of an apartment house form a group on the basis of their sharing this particular building, so we, on the strength of the political and legal institutions that provide our general living together with all the normal channels of communication, become a social group, a society, a people' (EU: 357$)$.

${ }^{21}$ Stephen Holmes illustrates this power generating potential of promising by comparing constitutions to the rules of a game. Whereas regulative rules govern pre-existent activities (e.g. 'no smoking'), constitutive rules 'make a practice possible for the first time' (e.g. 'bishops move diagonally'). Constitutive rules, in this way, are not primarily disabling but enabling. They do not merely restrain power but assign and channel power.
} 
law of the polity seems to require a more stable ground than the promises of men can provide. In order to arrest the potentially destructive aspect of democratic will, it seems that revolutionaries must appeal to a higher source of authority - an Absolute - to authorise the fundamental law they seek to establish.22

Such an appeal to an Absolute is articulated, for instance, in the Preamble of the Declaration of Independence, which states 'we hold these truths to be self-evident' (OR: 192). As Arendt discusses, Jefferson's famous words paradoxically combine a relative agreement with an Absolute. ${ }^{23}$ To the extent that the truths of the Declaration are 'held' by those who articulate them they are a matter of opinion. They are relative because they relate those who acknowledge their authoritative status for the life of the polity. Yet, if they are self-evident they stand in no need of agreement because they compel with the force of reason. Their self-evidence 'puts them beyond disclosure and argument' so that 'they are not held by us but we are held by them' (OR: 192, 193). ${ }^{24}$ Their validity is independent of the democratic will. With this appeal to self-evidence, Arendt argues, Jefferson promotes reason to a transcendent source from which the legitimacy of the legal constitution is derived. Yet, she suggests, he must have been aware that the claim 'all men are created equal' is not self-evident to all or he would not have felt it necessary to include the performative "we hold", according to which moral truth becomes politically relevant.

Although the need for an Absolute was revealed in the moment of foundation, Arendt suggests that this dilemma was, in part, based on a

\footnotetext{
22 The mistake of the French Revolution, according to Arendt, was that it identified the will of the people as the source of both power and law. Yet since the will is by nature changeable, it subjects the law to the movement of politics, as was evidenced in the multitude of decrees and ordinances that were produced, which became obsolete the moment they were enacted, 'swept away by the Higher Law of the Revolution' (OR: 183). Similarly, in the case of the totalitarian regimes of the twentieth century 'the term "law" itself changed its meaning: from expressing the framework of stability within which human actions and motions can take place, it became the expression of the motion itself' (OT: 464)

${ }^{23}$ Or, as Honig (1991: 99) puts it, in terms of Austin's speech-act theory, it combines a performative utterance with a constative.

${ }^{24}$ As Bonnie Honig (1991: 100) observes, 'The appeal to self-evidence stands in opposition to the We hold. It expresses not a free coming together but an isolated acquiescence to compulsion and necessity. The appeal, therefore, coerces and disempowers. It violates the integrity of politics and denatures and disables it in practice.'
} 
misunderstanding of the nature of law. Only if law is conceived in terms of a commandment to which men owe their obedience irrespective of their consent and agreement does it require an absolute foundation (OR: 189). ${ }^{25}$ For the Romans, the law needed no such basis but was the outcome of conflict. Law was predicated on an alliance, which not only established peace but constituted a new unity between two different entities that had been thrown together by war. Thus, a war was concluded to the satisfaction of the Romans not merely with the defeat of an enemy but 'only when the former enemies became 'friends' and allies (socii) of Rome' (OR: 188). The Romans thus recognised in alliances and covenants a powerful institution for the 'creation of politics at the point where it was reaching its limits' (Arendt in Tamineaux 2000: 176). ${ }^{26}$ Indeed, the res publica was itself the outcome of war between the patricians and plebeians, 'whose internal strife was concluded through the famous laws of the Twelve Tables' (OR: 188). Moreover, the foundation myth of Rome was based on Virgil's reversal of the Homeric epic of the sacking of Troy according to which the 'end of the war is not victory and departure for one side, extermination and slavery and utter destruction for the others, but 'both nations, unconquered, join treaty forever under equal laws' [Virgil] and settle down together' (OR: 209). On this account, as Jacques Tamineaux (2000: 176) puts it, law is the 'institution of a relationship between conflictual sides of a pluralistic interaction.' Law expresses a relation or rapport (Montesquieu) rather than an imperative and so has no need of absolute validity (OR: 188-189).

As we have already seen, Arendt proposes to solve the problem of the Absolute, which seems to be required in order to break the vicious cycle of constitution, by looking not to a source of authority that transcends politics but to the foundational act itself (OR: 213). The founding act, in which the freedom to begin is dramatically enacted, becomes exemplary for all future action. The authority of the constitution thus depends on its illumination by the memory of the founding itself. For unlike law, which can only set limits

\footnotetext{
25 This traditional concept of law was an inheritance from: 1) the Hebrew tradition in terms of which law was understood on the model of the ten commandments; 2) the Christian tradition according to which an Absolute appears in history as the "word made flesh", and; 3) the Absolutist regimes displaced by the eighteenth century revolutions.

${ }^{26}$ For alliances allowed the extension of politics beyond 'relationships between citizens of one and the same City' (as the Greek conception of politics was limited) to include relations 'between foreign and dissimilar nations' (Arendt in Tamineaux 2000: 177).
} 
to action, the beginning carries its own principle in itself, which inspires the subsequent acts of citizens (OT: 467; OR: 212). In this context, Arendt suggests that 'the authority of the republic will be safe and intact as long as the act itself, the beginning as such, is remembered whenever constitutional questions in the narrower [legal] sense of the word come into play' (OR: 204). By conceiving authority in terms of augmentation of the founding act, Arendt claims to have established the basis on which change and permanence are tied together such that 'change could only mean increase and enlargement of the old' (OR: 201).

Yet, intriguing as Arendt's attempt to reconcile the contradictory constitutional moments of performance and legislation is, this is a reconciliation that ultimately fails. For, in emphasising the relational aspect of law - its capacity to create politics at the point at which it reaches its limits - she tends to neglect the extent to which this achievement rests on a reduction that simultaneously forecloses politics. If the achievement of law is that it establishes certainty and stability in human affairs, its failing is that it tends to over-determine the terms in which we make sense of the world. As system of representation, law reduces the vast complexity of the world by filtering information as either fulfilment or disappointment of the expectations it institutionalises. Consequently, much that happens in the world does not register at all or registers only on the law's own terms (Christodoulidis 2000: 198).

Thus, as Christodoulidis (2001b: 124 - emphasis in original) explains, a legal constitution at once 'frustrates and facilitates the political': facilitates, as Arendt recognises, by staking out 'joint boundaries' in terms of which it is possible for adversaries to engage in a rational dispute that lends itself to resolution; yet frustrates, as she sometimes forgets, because in order to discipline conflict the law must represent it selectively 'by setting the thresholds of valid dissensus, the when and how of possible conflict. ${ }^{27}$ In allowing political conflict to be 'played out and resolved as internal to the constituency' in this way, law 'removes any potential threat to the

\footnotetext{
${ }^{27}$ I say sometimes forgets because Arendt shows an awareness of this reductive tendency of institutions when she writes that the 'moment promises lose their character as isolated islands of certainty in an ocean of uncertainty, that is, when this faculty is misused to cover the whole ground of the future and to map out a path secure in all directions, they lose their binding power and the whole enterprise becomes self-defeating' (HC: 244).
} 
constituency, i.e. to the unity of the polity' (Christodoulidis 2001b: 127-128 emphasis in original). Since conflict can be concluded satisfactorily only with the establishment of society between former enemies, the law must represent political conflict as always-already communal.

Against Arendt, then, we must recognise the paradox of constitution as real and unavoidable, since it involves the articulation of the irreconcilable logics of law and politics. Constitutional democracy is, as Christodoulidis (2001b: 122) puts it, 'a hybrid, harbouring and enabling the co-existence of two radically incommensurable orders: one that is driven by disruption, and openness and is thus radically contingent; and one that is driven by the need to reach a state of order through normative closure and the curtailment of contingency.' 28 This paradox expresses itself in temporal terms, as we have already seen, in the way in which politics and law invoke the "we" of the constitution. Whereas law looks to the past in order to bring the future under control (i.e. by reducing contingency through securing expectations), politics freely inclines into the openness of future, imports the risk of what is not yet as its enabling condition in the present (Christodoulidis 2000: 196-199). If reconciliation relies on the under-determination of community to constitute a space for politics in the first instance, a legal constitution tends to undercut political reconciliation by making community a regulative ideal and, hence, over-determining the terms within which a reconciliatory politics can be enacted. A legal constitution thus seems to be predicated on a necessary forgetting of the founding act that brings it into being, the moment of beginning which imports an awareness of the frailty and contingency of community.

Yet, with Arendt, we might resist this tendency to forget by invoking politics as indispensable in prolonging the present moment in which the intention 'never again' is expressed. What I want to take from Arendt, then, is the idea that political reconciliation is impelled by an anticipated

\footnotetext{
${ }^{28}$ Similarly, Mouffe (2000: 2-3) writes: 'It is crucial to realize that, with modern democracy, we are dealing with a new political form of society whose specificity comes from the articulation between two different traditions. On one side we have the liberal tradition constituted by the rule of law, the defence of human rights and the respect of individual liberty; on the other the democratic tradition whose main ideas are those of equality, identity between governing and governed and popular sovereignty. There is no necessary relation between these two distinct traditions but only a contingent historical articulation.'
} 
remembrance, which emerges in the act of constitution out of the (ultimately impossible) effort to hold together the world-rupturing and world-delimiting moments of beginning and promising. As such, political reconciliation is impelled, on the one hand, by the recasting of the present as a point of origin and, on the other, by the attempt to memorialise this beginning by promising "never again". It is from the effort to hold together these two moments that a "we" might be constituted, in terms of which a collective reckoning with the past becomes possible. Yet, against the tendency of a legal constitution to over-determine the terms within which this "we" is constituted, political reconciliation must be conditioned by a sense of the risk of this venture: that the beginning we seek to enact in the present might not be remembered as such.

\section{4 "We the people"}

Bruce Ackerman (1992: 5-6) defines revolution as a 'successful attempt to transform the governing principles and practices of a basic aspect of social life through an act of collective and self-conscious mobilisation'. In this context, constitution should be understood not just in terms of the procedures and rules that discipline conflict but as the performative act in which 'a people constitutes itself into a body politic' (OR: 203). This aspect of constitution is vivid in the transitional moment of political reconciliation when 'citizens are most alive to their problem in political construction: How, given fundamental disagreements, are they to elaborate principles of justice that will give all a fair and equal opportunity to pursue their different lives?' (Ackerman 1992: 26). It is because the identity of the people cannot be taken for granted at such times that citizens are aware of the fragility of community. In these circumstances, constitutional politics inevitably turn around the question: who are "we"? It is by raising community as a question, in this way, that constitution initiates political reconciliation.

Of course, given the role a legal constitution is supposed to play in preventing state wrongs, there are other, common sense reasons why so much attention is paid to constitutional issues during a transition to democracy. The legitimacy of modern government depends upon its limitation by the rule of law whereas tyranny comes about when the will of 
the sovereign is presumed to be above the law (see 2.3). Constitution-making during a political transition, therefore, is typically associated with 'restoring' the rule of law, the reinstatement of a publicly known set of procedures by which to arbitrate political conflict and secure the rights of citizens. The turn to constitutionalism thus underscores both the legitimacy of the new regime (as Rechtstaat) and the illegitimacy of the old (Unrechtstaat). Whereas the legitimacy of the Rechtstaat depends on its 'self-binding', its commitment to abide by publicly agreed decision-making procedures, the illegitimacy of the Unrechtstaat was due to its failure to be bound by such predetermined procedural limitations to power. These kinds of concerns were clearly foregrounded, for instance, during the transitions to democracy in Eastern Europe following the collapse of the Soviet Union (see McAdams 2001: 41f.; Pribán 2002; Borneman 1997).

Yet, as Ackerman emphasises, the creative aspect of constitutionmaking is equally important. Negotiation over a new constitution provides a 'crucial mechanism' through which former enemies 'try to work out the terms of their new beginning together' (Ackerman 1992: 116). Indeed, Ackerman insists that this unifying project of constitutional creation should take precedence over the divisive concern with corrective justice, which tends to emerge from a rights-centred approach. For while an emphasis on corrective justice tends to divide a citizenry into 'evil doers and innocent victims', the framing of a constitution 'invites citizens to put the past behind them and to think about how they all might contribute to a definition of the new order' (Ackerman 1992: 70-71). Leaving aside doubts about what 'putting the past behind' means here, I agree with Ackerman that, given its orientation to the future, the constitution of a space for politics may initiate political reconciliation. However, I share Christodoulidis's (2000: 192-194; 2001b: 166-122) suspicion that Ackerman (like other republican legal theorists) is unduly optimistic in entrusting to a legal constitution the task of sustaining a reconciliatory politics.

For, as we have seen, law frustrates political reconciliation by representing community as the given end of politics rather than a contingent historical possibility that conditions the possibility of politics in the present. The tendency of a legal constitution to undercut the ethical constitution of a "we" in this way was demonstrated, for instance, in the constitutional 
politics of South Africa. The temporal modality of political reconciliation is clearly revealed in the much cited postscript to the Interim Constitution of South Africa (1993), in which it is declared: 'With this constitution and these commitments, we the people of South Africa open a new chapter in the history of our country' (emphasis added). The constitution is supposed to provide 'a historic bridge between the past of a deeply divided society, characterised by strife, conflict, untold suffering and injustice, and a future founded on the recognition of human rights, democracy, peaceful coexistence and development for all South Africans,' Moreover, it should establish the 'foundation for the people of South Africa to transcend the divisions and strife of the past', which left a 'legacy of hatred, fear, guilt and revenge' (cited in de Lange 2000: 21).

The present of the interim constitution is taken as a point of origin, a transitional moment between the 'no more' of civil strife and the 'not yet' of peaceful coexistence. In this context, the twofold aspect of constitution as beginning ('opening a new chapter') and promising ('these commitments') is explicit. But, as Christodoulidis (2000: 190-194) discusses, this renders the "we" that is invoked in the constitution problematic. For just as there could be no collective identity (no unified 'people' of South Africa) in the past characterised by strife and gross violations of human rights, so the legacy of hatred, fear and guilt precludes community in the present. The "we" that is invoked in the interim constitution can belong, then, only to the democratic future. And yet, since the legitimacy of the constitution is founded on the restoration of community, it must presuppose the continuity of this community (albeit a community that was previously divided) over time. But, as we saw in 3.3, in this the constitution makes an unwarranted presumption of a "we" since it elides the risk of politics by re-presenting the conflict of the past as communal. In doing so, the law takes as a given what political reconciliation is supposed to achieve: the performative constitution of a "we". In legal terms, the conflict of the past can only be 'resolved' and community thereby 'restored' by a reductive representation that silences political objections that question the legitimacy of the "we". Yet it is precisely the possibility of such questioning that is the enabling condition of a reconciliatory politics in the first place. 
If reconciliation is to be conceived politically, it must accommodate the risk that the beginning on which it is predicated may not eventuate. Though less dramatic than the transitions to democracy in South Africa and elsewhere, demands for constitutional recognition by indigenous groups in settled democracies may be similarly understood as attempts to establish such a new beginning, what Ackerman would call a constitutional moment (e.g. see Tully 1995: 1-25). It was no coincidence, for instance, that Aboriginal demands for a treaty coincided with the debate over whether Australia should become a republic in the late 1990s. For what was at stake in both issues was the question of identity of the Australian 'people', their relationship to their government(s) and the terms of association between settler and indigenous societies. Constitutional politics in Australia in the 1990s turned around competing interpretations of the founding moments of the state. While the settler society celebrated its bicentennial in 1988, many indigenous Australians and their supporters mourned what they called 'invasion day'. Similarly, during the republican conventions leading up to the celebration of the centenary of federation in 2001, Aboriginal leaders called attention to the fact that indigenous Australians were omitted from the original contract on which the foundation of the Commonwealth of Australia was based (Rowse 2002: 30).

State commemorative activities in this way provided focal points that were understood by some to present a political opportunity to establish a new beginning by calling into question the legitimacy of the "we" represented in the constitution while for others they were supposed to consolidate state sovereignty. While, for one side, the possibility of reconciliation depended on inaugurating a new friendship between settler and indigenous societies, on the other it depended upon leaving the past behind by assimilating indigenous Australians into the broader society. For instance, in his 1992 Redfern Park speech, Prime Minister Paul Keating (2000: 62) declared that the High Court's Mabo decision provided 'an historic turning point, the basis of a new relationship between indigenous and nonAboriginal Australians'. Yet, this was a beginning that never eventuated. For, under the Howard government, recognition of native title provided a legislative framework for reconciliation by extinguishment (as we saw in 3.4). 
Despite the well-attended celebratory marches for reconciliation in the 1990s, many indigenous Australians continue to insist that there is unfinished business between the settler and indigenous societies. In calling for a treaty, indigenous Australians have sought to establish a framework within which the new beginning that reconciliation was supposed to have establish might become more meaningful. A treaty would provide a measure of historical justice by recognising that indigenous peoples did have a political claim over the territories that were appropriated from them by the settlers and that treaties ought to have been sought with them at the time of settlement (Thompson 2002: 29f.). In this context, the failure to provide for constitutional recognition of indigenous Australia perpetuates this original justice into the present.

In the absence of a treaty, argues Aboriginal and Torres Strait Islander Commission (ATSIC) chairman, Geoff Clark (2000: 229), reconciliation is like 'a football game without goal posts or accepted referees'. The value of a treaty for Clark is the measure of continuity and certainty it would bring to relations between indigenous people and the settler society. For the history of indigenous peoples' dealings with the state 'leaves us suspicious. Decisions and agreements reached during one term are too easily revoked during the next.' What is required, rather, is 'an explicit commitment about our place in the community that will endure changes in political fortunes' (Clark 2000: 233). Without the common reference point that such a promise would establish there is only a directionless and futile talking-past-eachother. The opportunity for a meaningful political dialogue between indigenous and non-indigenous Australians - one which might transform their historical relation to each other - is undermined.

These examples reveal how a legal constitution both reduces and makes available political opportunity. By establishing a common reference point, it provides an opportunity for a meaningful dissensus. In this context, law institutes a relationship between conflicting sides of a pluralistic interaction. Consequently, the absence of a treaty in Australia appears to undermine reconciliation between indigenous and settler societies, since politics lacks a stable ground that the institution of common expectations establishes. However, as system of representation, a legal constitution renders conflict resolvable by reducing contingency, which is the enabling 
condition of politics. As such, a legal constitution forecloses the opportunity to contest the terms within which such a relationship is determined. Thus, because the legal constitution of South Africa presupposes that the conflict of the past will turn out to be communal, it cannot represent an objection that might call into question the legitimacy of this community in the first place.

Following Arendt, there can be no collective subject that pre-exists the act of constitution Rather this "we" emerges from political interaction. Since the possibility of this "we" depends on its ongoing actualisation through public action and speech, a legal constitution cannot guarantee community. As foundational act, constitution invites the risk and promise of politics by establishing reconciliation as a 'joint enterprise in time' (Bankowski 2002). As foundational law, however, it elides both by institutionalising the terms within which reconciliation is to be enacted such that any conflict which might call into question the legitimacy of community fails to register as meaningful. The ethical constitution of a "we", then, cannot be entrusted to the 'rule of law', but ultimately depends on the willingness 'to live together with others in the mode of acting and speaking' (HC: 246).

The ethical constitution of a "we" therefore depends on forsaking the certainty of law for the risk of politics. As such, the attempt to enact a new beginning in the present and to memorialise this beginning by promising "never again" always involves a leap of faith. It politicises reconciliation by inculcating an awareness that there is no inevitability to community; that the conflict of the past might turn out to drive communities further apart than bring them closer together. Yet, invoking community as a contingent future possibility also enables a reconciliatory politics in the present by projecting a shared horizon in terms of which former enemies might come to understand the past. As we shall see, this fragile politics can only be kept in play by a willingness to forgive, which enables us to resist the power of the past to determine the possibilities of the present. 


\section{Forgiveness}

I have just argued that political reconciliation is initiated by constituting a space for politics, which entails both beginning and promising. Because the "we" that is invoked in the founding moment is always not-yet, beginning conditions an awareness of the frailty and contingency of community. On the other hand, instituting shared expectations by promising "never again" conditions the possibility of community in the future by memorialising this beginning. Yet, because law establishes certainty through institutional closure, we cannot trust a legal constitution to hold open a space for politics. To be kept in play, rather, the fragile politics of reconciliation depend on the good will of those who would share a world in common to counter the risks of action by promising and forgiving.

If promising mitigates the unpredictability of action, forgiving mitigates its irreversibility. As unconditioned response rather than mere reaction to an other who has wronged us, forgiveness brings to an end a process initiated by an original wrong, which might otherwise have endured indefinitely in human affairs. Constitution clears the way for forgiveness by establishing a measure of security against the unpredictability of the future. This is required before those wronged might reasonably countenance community with their former oppressors. Yet, I will argue in this chapter, the possibility of reconciliation depends further on a willingness to forgive, which sustains a space for politics between former enemies. Against insisting that our enemy agrees with the moral truth of his wrongdoing before we engage him in inter-action, a willingness to forgive makes possible a reconciliatory politics by refusing to allow the past to determine the possibilities of the present.

As I discuss in 7.1, forgiveness involves not only relinquishing a just claim against one who has wronged us but setting aside resentment against 
one's enemy. While it may not be possible to cease resenting the other as an act of will, it is possible to want to forgive and to seek grounds for setting aside resentment. Yet, as I argue in 7.2, neither necessity nor reason are adequate grounds for political forgiveness. For if a willingness to forgive depends on the dictates of necessity it is reduced to compromise whereas if it is constrained by the logic of Right it becomes redundant. Following Arendt, I argue in 7.3 that appropriate grounds for forgiveness in politics are, rather, the natality of the other and frailty of the world. Political forgiveness, on this account, does not refer to the closing moment of reconciliation in which wrongdoers are restored to community with those they have wronged. Rather, wanting to forgive makes possible a politics in which members of a divided polity contest each other's understandings of the violence of the past and its significance for their political association. In 7.4, I consider the relation between amnesty and political forgiveness in the workings of the Truth and Reconciliation Commission in South Africa. ${ }^{1}$

\subsection{Setting aside resentment}

Forgiveness involves not only renouncing one's just claims against an other but setting aside a resentful view of her as 'the one who wronged me' (Hampton 1988a: 38). Ceasing to identify the other with the consequences of her actions establishes the possibility of friendship in the wake of wrongdoing. While we do not cease to judge the other's actions as wrong, we open ourselves to an understanding of her that is more encompassing than her singular relation to us as our transgressor. Yet resentment is not set aside easily. Nor, perhaps, ought it be. As Jeffrie Murphy (1988: 14-34) observes, we quite properly feel resentful in response to being wronged. What we resent is not only the material harm inflicted on us but the insulting message the harmful act carries with it. In wronging us the other reveals her contempt for us by failing to treat us as a moral equal. As response to this demeaning experience, resentment involves a defiant assertion of one's value and entitlement to respectful treatment. Resentment is oriented to the recovery

\footnotetext{
1 This chapter is based on my (2003) article 'Political grounds for forgiveness', Contemporary Political Theory 2(1): 77-87.
} 
and confirmation of one's moral status, which is called into question by a wrong. ${ }^{2}$

If we are often right to resent our transgressor, then, there may be circumstances in which we are wrong to forgive her. A forgiving disposition is commendable so long as it keeps resentment within proper bounds, checks it against the excesses that arise from human weakness and vanity (Murphy 1988: 15). Yet to forgive too readily may be to acquiesce in wrongdoing. Forgiveness risks lapsing into 'condonation' when we do not protest but simply overlook a wrong in order to maintain a relationship with the other (Kolnai 1977: 215-216). Being too ready to forgo resentment may betray low self-esteem and so constitute a failure 'to take oneself, one's projects and one's entitlements seriously enough' (Novitz 1998: 306-307). Or it might reflect a moral indifference to the other as someone who is "not worth my time". In this context, Murphy (1988: 24) insists that genuine forgiveness is not simply ceasing to resent but 'forswearing resentment on moral grounds' (Murphy 1988: 24). According to Murphy (1988: 24), forgiveness should be 'compatible with self-respect, respect for others as moral agents, and respect for the rules of morality or the moral order'. As such, forgiveness is only appropriate if the wrongdoer demonstrates genuine remorse. For, in doing so, he withdraws his endorsement of the insulting message the wrong communicated and re-affirms his commitment to the shared norm he violated.

Yet, as Jean Hampton (1988a: 36-37) argues, to insist too strongly on having moral reasons to forgive is to miss the gift-like nature of forgiveness (see also Twambley 1976). While retribution, remorse, reparation and restitution may make us more inclined to forgive they cannot be necessary conditions for forgiveness. For to demand reasons why one ought to forgive is, in fact, to assume an unforgiving disposition (North 1987: 505). Forgiveness becomes redundant when we reserve it only for those who have earned it from us. For then it is simply the acknowledgement that we are no longer the victim, that we are no longer justified in resenting our

\footnotetext{
${ }^{2}$ As Pamela Hieronymi (2001: 547) puts it, 'Resentment affirms what the act denies - its wrongness and the victim's worth. And so, in a way, resentment is a fight response. It fights the meaning of the past event, affirming its wrongness and the moral significance of the victim and the wrongdoer'.
} 
transgressor (Kolnai 1977: 217). In its gift-like aspect, by contrast, forgiveness is an offer of trust in advance. While our transgressor does not deserve our forgiveness, we venture it nonetheless for the sake of a potential relationship. By offering forgiveness we invite our transgressor into society with us and, thus, make ourselves vulnerable to being wronged again. But, in doing so, we present our wrongdoer with an opportunity to recognise the wrongfulness of his actions and assume responsibility for them. In this way, forgiveness forgoes guarantees, the certainty of reasons, 'in favour of a boldly, venturesomely aspiring and active pursuit of Value' (Kolnai 1977: 233).

The possibility of setting aside resentment, of comprehending the other as more than one's transgressor, must be allowed if there is to be a place for hope and trust in the politics of a divided society. However, those who have been the victims of an unjust regime might quite rightly be suspicious of the quietism implicit in making a political virtue out of forgiveness. From the perspective of the oppressor, the virtue of Christian practice of forgiveness may be that it assists in 'calming down the natives' (Fanon 1965: 53). Those who continue to benefit from unjust social arrangements are likely to counsel the oppressed to 'forgive and accept' when, arguably, they ought to 'resent and resist' (Murphy 1988: 11). Resentment may have an important role to play in politics, then, in animating protest, thereby drawing attention to the rights and respect due to members of an oppressed social group. It may sometimes be politically appropriate to resent those implicated in past wrongs by virtue of their position as beneficiaries of an unjust regime or as members of a group whose values are sovereign (Memmi 1990: 78-79). Indeed, such just resentment often animates demands for recognition. Central to a politics of recognition is the defiant self-assertion of an oppressed group, the reclamation of historical agency by remembering the past from the perspective of the defeated. Important as this task may be, however, it risks entrenching resentment. For such a history may fixate on grievances and emphasise 'events that reinforce [a group's] sense of injustice and bruised pride' (Novitz 1998: 305). While the demand for recognition often entails only the claim that a social group receives its due, when nurtured by a moralistic and unforgiving disposition, the fact of historical oppression may be taken as 'proof of ultimate merit' (Little 2001: 142). 
The establishment of friendly civic relations in a polity divided by past wrongs depends upon the possibility of setting aside the hard feelings occasioned by painful memories without forgetting or condoning what went before. The memory of offence may preclude the possibility of giving up resentment or hatred of our former enemy as a simple act of will. Yet, as David Novitz (1998: 309) recognises, it is possible to choose whether to fuel resentment through stubborn partiality or to seek grounds for forgiveness by entertaining the perspective of our transgressor. The task of relinquishing resentment, on this account, begins from a 'willingness and ability to see things differently and to depart from our own settled perspective' (Novitz 1998: 309). Wanting to forgive might, in this way, sustain a reconciliatory politics between former enemies in the absence of a moral consensus on the significance of past wrongs.

Cheshire Calhoun (1992) provides an insightful account of how one can be true to the past without making forgiveness conditional on the wrongdoer's repudiation of her acts. Grounds for the 'aspirational forgiveness' Calhoun advocates are revealed to us through telling a story that makes biographical, but not necessarily moral, sense of how the other could wrong us. Such as story is not intended to show the other as one worthy of forgiveness by separating the sin from the sinner. Rather, it situates the wrongs perpetrated against us in the biographical context in which the other makes sense of her own actions. This leads to a kind of understanding that confirms our perception of the past and the injury perpetrated against us. But it does not demand that the one who wronged us be different from what she is before we are willing to entertain society with her. We find grounds for overcoming resentment by making our transgressors' actions intelligible 'by forgivingly understanding how they have made sense of their lives' (Calhoun 1992: 96). Importantly, in the context of political reconciliation, this means engaging with the collective meanings and narratives by which our former enemy might have made sense of his life as, for instance, a freedom fighter rather than a terrorist. 


\subsection{Inadequacy of necessity and reason}

The value of forgiveness in our intimate relations with others is clear. In relations of love we are both most vulnerable and most likely to trespass moral bounds. Moral injury is so common that without the mutual capacity for forgiveness we could not sustain any friendship for long. Yet, although trespass is also frequent in politics, the appropriateness of forgiveness in public life is less obvious. As Arendt observes, although promising has long been recognised as indispensable to political life, forgiveness has 'always been deemed unrealistic and inadmissible in the public realm' (HC: 243). Realists, who construe politics in terms of strategy and power, are likely to consider a forgiving disposition soft-headed and bound to bring an actor to grief or else to suspect that it cloaks some particular interest he is actually pursuing. Liberals, anxious to devise just institutions to contain politics, are bound to worry that the partiality of forgiveness will compromise justice or that it will lead to intrusive demands being made of citizens. Whereas the former would subordinate forgiveness to the dictates of necessity, the latter would constrain forgiveness within the bounds of reason.

For the realist, forgiveness must be compatible with a 'responsibility to the future' that involves weighing 'objective interests that come into play' (Weber 1948: 116). In politics, according to Max Weber, an 'ethic of absolute ends' (which counsels the relentless pursuit of justice irrespective of its consequences in the world) must be tempered by this 'ethic of responsibility'. An ethic of ultimate ends is concerned only with the goodness of action. As such, it tends to encourage actors either to withdraw from worldly involvement (for fear of dirty hands) or to engage in revolutionary millenarianism (the appeal to commit one last evil to end all evils). By contrast, an ethic of responsibility demands a sensitivity to the consequences of our actions and a willingness to do what is necessary, which may mean employing morally dubious means, in order to secure the best outcomes in political affairs. Forgiveness (or its refusal) is unpolitical when animated by an ethic of absolute ends because it fails to recognise non-moral constraints imposed on action by circumstances. To follow the command to love one's enemy and turn the other cheek when wronged without regard for 
circumstances and consequences is therefore likely to lead to disaster in politics.

On the other hand, the political realist may be willing to forgo a just claim for retribution when this appears necessary for the survival of the political association. Conceived in terms of an ethic of responsibility, political forgiveness suggests what Peter Digeser refers to as a 'take-it-on-the-chin' attitude on the part of the victims. Acknowledgement of the tragic choices political actors must sometimes confront in politics suggests that those who become victims of political wrongs ought to 'simply accept that this is how the world works (sometimes we must do evil and sometimes we must suffer it) and get on as best we can' (Digeser 1998: 711). This kind of willingness to overlook wrongdoing for the sake of social harmony might be appropriate in certain political circumstances: for instance, when amnesty is granted to perpetrators in order to secure a peaceful transition to democracy. However, following Kolnai, forgiveness is reduced to condonation when justified in these terms. Whereas forgiveness condemns the wrong but seeks to set aside the resentment it occasions, condonation waives moral judgement entirely.

Furthermore, taking necessity as the ground of political action ultimately leads to cynicism in relation to the possibility of forgiveness in politics. For the realist is likely to suspect, with Nietzsche, that the weak wield the offer of forgiveness (which presupposes the guilt of those it is offered to) as a rhetorical instrument by which to gain political influence (see Digeser 1998: 705). Since politics is construed as a means through which actors pursue goals, talk of forgiveness can only obfuscate the material interests that are really at stake in political conflict. By keeping one eye fixed on the past, concern with forgiveness and guilt distract attention from the future with which the political actor is properly concerned. ${ }^{3}$ For the realist, the past has only marginal political importance in relation to the immediate

\footnotetext{
${ }^{3}$ Significantly, necessity provides not only a basis for assuming political responsibility (i.e. a willingness to do what is necessary) but also mitigates responsibility for wrongdoing. This is evident, for example, in the case of the state agent who 'regrets' the excesses of the oppressive regime he supported while insisting that these resulted from the necessary task of ensuring the security of citizens. Similarly, the freedom fighter who 'regrets' the civilian casualties inflicted through attacks on infrastructure but insists that such losses were an unavoidable consequence of a just war waged against an illegitimate regime. Appealing to necessity in this way shifts the attribution of 'responsibility' for wrongdoing from the agent who commissioned the act to the circumstances in which he acted.
} 
clash of interests and might as well be forgotten in order to concentrate our attention more thoroughly on shaping the future (Weber 1948: 198). Moreover, in the absence of freedom, forgiveness loses it normative significance as an invitation to society with the other. When those wronged forgive out of necessity (the recognition that they lack the power to pursue their claims to just retribution) forgiveness is not freely given but bargained away (van Roermund 2001: 181).

By contrast, liberals, who are concerned to establish and preserve the rule of law following grave state wrongs, demand moral reasons for forgiveness in politics. If politics is the public means through which the private freedoms of individuals are secured, then forgiveness is appropriate in the public sphere only if it does not exceed or compromise the rights and duties of citizenship appropriate for a plural society. We ought to forgive only if this is compatible with the dictates of justice and we need only forgive to the extent that this makes possible the minimal level of civility necessary to maintain peaceful civic relations.

Forgiveness sits uncomfortably with a liberal politics that 'shies away from demanding purity of heart from its citizens' (Digeser 1998: 705). For this reason, Digeser argues that it is a mistake to conceive political forgiveness in terms of overcoming resentment. For such an ideal of forgiveness is too demanding within a large political association that must accommodate moral plurality. While it may be laudable to strive to overcome resentment towards others in our private lives, we stretch the bonds of ordinary human sentiment too far in seeking to extend such generosity to those with whom we lack sustained emotional contact and whose values seem alien to our own. Moreover, it may be too intrusive, given the difficulty of properly discerning how people feel in the public sphere for political forgiveness to require a change of heart in the person wronged. Consequently, Digeser advocates a form of political forgiveness in terms of which citizens might publicly affirm their commitment to civic association with their former enemies while continuing to resent them in private.

Moreover, Digeser is concerned about the potential for short-circuiting justice that a willingness to forgive might lead to. There is a paradoxical relation between forgiveness and justice, which revolves around the problem 
of whether forgiveness is 'other' than justice. If forgiveness involves forgoing one's just claim against another this seems to implicate forgiveness in injustice. Kant, for instance, was 'suspicious of philanthropy, mercy and forgiveness in their efforts to limit justice. Fellow feeling is a duty but should not be allowed to dilute the demands of morality and justice' (Booth 2001: 783). Yet, if we should only forgive the other as justice demands, then forgiveness becomes redundant. In order to reconcile the possibility of forgiveness in politics with the dictates of justice and the demands of democratic citizenship, Digeser (1998: 706-708) argues against a gift-like conception of political forgiveness. While in our private life we might bestow forgiveness as a gift on an undeserving wrongdoer, in public life forgiveness cannot be a mysterious act of grace but must be predicated on reasons that are consistent with the demands of democratic citizenship. In his view, political forgiveness ought not be an alternative but a supplement to procedural justice. Political forgiveness ought to be offered in recognition of the imperfection inherent in basically just institutions and, as such, ought to 'pick up where justice reaches its limits' (Digeser 1998: 708). We ought to forgive state wrongs only when these are the outcome of basically just institutions, which realise justice imperfectly due to the complexity of the moral world.

The thin conception of political forgiveness that Digeser is led to advocate confirms the point I made in 2.3 that liberalism tends to deny reconciliation as a legitimate political aspiration. Both resentment and its overcoming, on this account, are fundamentally private emotions, appropriate in intimate and social relations with others, but certainly not the proper object of politics. While, following Arendt, it is indeed true that what counts in politics is the way we appear to others rather than our 'inner' emotional state, resentment is political when its enactment communicates a judgement of worth about the other. To argue that resentment and its overcoming are not political is, then, to limit value conflict in the public sphere and, thus, to avoid the kind of agonistic encounter with the other that might lead to the disclosure of the world in its commonness.

Moreover, taking moral reason as the only legitimate ground for forgiveness in politics precludes forgiveness as a legitimate response to injustice in those situations in which it is most needed. Due to his concern 
that forgiveness might lead to the short-circuiting of justice, Digeser (1998: 707) insists that political forgiveness 'should not be performed unless the government has publicly acknowledged the wrong that it has done; victims and transgressors must agree on a history of what has happened'. However, making political forgiveness conditional on a shared account of past wrongs, is to set a very hard condition for reconciliation indeed. Political forgiveness would be a simple matter in a polity whose members could broadly agree on the significance of past wrongs. For such a polity would no longer be divided but would have largely accomplished what political forgiveness must help to bring about. Contrary to Digeser, forgiveness is most often invoked as a source of hope in politics when the possibility of consensus about the past seems remote.

Neither reason nor necessity will do, then, as political grounds for forgiveness. Conceiving forgiveness in relation to a courageous facing up to political necessity implicates it in the condonation of wrongdoing. Yet, to dissociate forgiveness from overcoming resentment and make it conditional on just reasons is to make it redundant in political life. By contrast, an ethic of worldliness accords forgiveness a central role in politics because it takes the frailty of the world and natality of the other as grounds for forgiveness.

\subsection{Political grounds for forgiveness}

Following Arendt, political grounds for forgiveness stem from a recognition of the predicament of non-sovereign freedom. Like promising, forgiveness is an inherently political faculty because it presupposes plurality. We learn the need to forgive and be forgiven from our experience of living together with others. Moreover, we depend on others to forgive us. No one can forgive himself because a forgiveness enacted in isolation from others could 'signify no more than a role played before one's self' (HC: 237). On this account, grounds for forgiveness in politics are the frailty of the world and the natality of the other. Forgiveness is an appropriate response to frailty since it saves the world from ruin by bringing to an end a process of reaction that would otherwise endure indefinitely in the web of human relationships. As response to natality, forgiveness releases the other from the consequences of her action. By no longer holding her to account for 'what' she is, forgiveness 
frees the other to engage in the play of the world. In its world-delimiting moment, as response to the frailty of the world, forgiveness brings a process of inter-action to an end. In its world-rupturing moment, as response to the natality of the other, it affirms the possibility of a new beginning.

Arendt writes that forgiving 'serves to undo the deeds of the past, whose "sins" hang like Damocles' sword over every new generation' (HC: 237). But, of course, they cannot be undone in any literal sense. The accomplishment of forgiveness, rather, is to refuse the past the power to determine the possibilities of the present. Arendt's notion of a process of inter-action that endures in the web of human relationships captures the sense in which a past event may persist in memory as a 'present threat' to a particular category of people within a polity. This threat is a semantic one in the sense that the event continues to exert a claim, in the present, of the subordinate social status of those wronged. As Pamela Hieronymi (2001: 546) argues, the memory of an offence that goes publicly unrecognised as wrong 'makes a claim. It says, in effect, that you can be treated in this way, and that such treatment is acceptable.' It is in this context that we ought to understand Arendt's point that the achievement of forgiveness, as with punishment, is that it 'put[s] an end to something that without interference could go on endlessly' (HC: 241). Punishment and forgiveness undo the deed in the sense that they undo its meaning or, as Hieronymi (2001: 550) puts it, they allow us to 'leave the original meaning of the event in the past' (see also Lang 1994: 115).

In the case of willed evil and crime, punishment rather than forgiveness is appropriate in order to undo the meaning of the wrong. Punishment, undoes the meaning of a wrong by negating the 'evidence of superiority implicit in the wrongdoer's original act' (Hampton 1988b: 129; see also Morris 1976: 126-127). Through the symbolic defeat of the wrongdoer at the hands of the victim, punishment annuls the significance of the original act as evidence of the wrongdoer's superiority. It annuls the insulting message of the wrong that perpetrator and victim are not equal in value. Punishment leaves the meaning of the act in the past in the sense that 'then' the wrong confirmed the subordinate social status of those it was perpetrated against, 'now' it is re-cognised as illegitimate act of oppression. Similarly, apology is intended to undo the meaning of a wrong by withdrawing 
endorsement of the insulting message the act communicated: 'then' I believed myself to be better than you, 'now' I recognise I was wrong to think so.

Likewise, a political undertaking to forgive is a struggle to settle the meaning of the wrongful act in the past for the sake of our life in common. As Memmi demonstrates in his portrait of the coloniser who can only choose between evil or uneasiness (see 3.3), we become implicated in certain stories enacted in the world (such as the story of colonisation), in which we may not want to be involved but which we are dragged into nonetheless according to our position in the world. As response to the frailty of the world, forgiveness undoes the meaning of a wrong by bringing to an end the story that implicates the other in an original transgression. Trust is ventured in this moment since it involves a suspension of judgement or what Jean-Bethke Elshtain calls 'knowing forgetting'. As Elshtain (2001: 43) writes, this does not mean that 'one falls into radical present-mindedness and the delusion that the past counts for nothing; rather, one assesses and judges just what the past does count for in the present - how much it should frame, shape, and even determine present events'. What is suspended is not judgement of the wrongness of the act, but the judgement that this confirms the other as one's enemy in the present. ${ }^{4}$ Trust is ventured for the sake of establishing a new relation based on mutual recognition of each other as co-builders of a common world.

To forgive the other for the sake of the fragile world one holds in common with her is, therefore, to forgive her in her neighbourly relation to us rather than on the basis of our shared moral status as rational beings or creatures of God. This entails a kind of political humility, an attitude of care and moderation. We forgive because we may also need to be forgiven. For only a person who believes he has no need of forgiveness could wish to live in an unforgiving world. In being politically disposed to forgive, then, one discounts the historical fact of oppression as evidence of moral superiority or collective innocence. The possibility of forgiveness depends in this way on an

\footnotetext{
${ }^{4} \mathrm{I}$ am indebted to Zenon Bankowski for pointing out how forgiving sometimes involves suspending judgement. I think this is what Arendt is getting at when she looks for nontheological terms for forgiveness as dismissing or releasing the other. Similarly, she prefers trespassing, missing, failing and going astray to 'sinning' and changing one's mind, returning, retracing one's steps to 'repenting' (HC: 240, n. 78).
} 
'awareness that there is a virtual reciprocity in what the oppressors did to the oppressed', that those wronged were on the side of good as a matter of historical fact not as a matter of principle, that is, 'not because they are the good people' (van Roermund 2001: 182-183).5 As response to frailty, forgiveness involves an awareness of evil as mundane in the sense that it is 'of the world'. This is to recognise, as Bert van Roermund (2001: 183) writes, 'that what the oppressors did to the oppressed belongs to the evil humans do to each other, and not to a mythic evil that intrudes on the world of humans from outside. In reconciliation, evil becomes "ordinary" in the profound sense of "among us".'6

As response to the natality of the other, forgiveness undoes the meaning of the wrong by ceasing to recognise the other only in terms of his past actions or those of his fellow group members. We undo the meaning of the deed as evidence of the identity of the other. As Arendt puts it, to forgive in this sense is to insist on seeing the individual as 'more than whatever he did or achieved' (MDT: 248). Forgiveness, in this context, is world-rupturing because it resists the categories by which we habitually make sense of the world, inviting the other to disclose that difference which exceeds his identity. This moment is hopeful since it is predicated on the potential inherent in the other to begin anew. To forgive for the sake of who the other is, is to release him from the consequences of his actions so that he can

\footnotetext{
${ }^{5}$ As Zenon Bankowski (2002) writes, 'Victimhood cannot be something that is pure and making of the victim holy. Resting secure in your victimhood defines your identity as timeless and unwilling to engage. The political consequences of that can be disastrous. The Afrikaner view of things was constructed through their view of the victim status at the hands of the British. This also applies in the Middle East. Placing the Holocaust out of time and making Israel always the eternal victim means we cannot live in the politics of time and place in the Middle East.'

${ }^{6}$ David Cooper (2001: 207f.) discusses something like this 'virtual reciprocity' in terms of "moral luck". He cites Nagel's example of circumstantial moral luck whereby most ordinary Germans were morally culpable for having failed to act heroically while citizens of other countries, who might have acted just as badly in the same circumstances, are less culpable simply because they were lucky enough not have faced the same test. Cooper suggests that while we should hold our transgressors collectively responsible for harms perpetrated against us, an awareness of moral luck should temper our moral condemnation of them as individuals (214). However, this seems to me a grave mistake, both morally and politically. For, as Arendt often points out, 'where all are guilty none is' (more on this in 8.2). Against Cooper, my point here is that recognition of virtual reciprocity ought to temper our collective resentment, even though we should continue to hold individuals responsible for their particular actions and inactions.
} 
remain a free agent. We forgive the other 'what' he is (our transgressor) for the sake of 'who' he might reveal himself to be through action.

The release that forgiveness offers is indispensable in politics to mitigate against despair at the moral irresponsibility and haphazardness that arises from the predicament of non-sovereign freedom. Care for the world must balance but not overwhelm that agonistic striving through which the difference of individuals and the common-ness of the world is disclosed. When care overwhelms the agent it gives rise to depressive guilt, a surfeit of which leads to withdrawal from the world for fear of being implicated in political injustice (see Little 2001: 194-196). It is in this context that the possibility of forgiveness allows us to remain free agents, willing participants in the play of the world. As response to the other that is 'unconditioned by the act that provoked it', forgiveness testifies to our shared potentiality to act anew (HC: 241). Forgiveness reveals the natality of the forgiver since, in contrast to retaliation, it is not a predictable re-action. Rather it is a response that is both unexpected and unpredictable. As such, it entails an invitation to the other to engage in politics with us.

An ethic of worldliness thus furnishes political grounds for forgiveness, which are not reducible either to those of the realist or the liberal. Forgiving for the sake of a fragile world has an affinity with an ethic of responsibility in that it is distinct from a more absolute form of forgiveness based on love. In undertaking to forgive for the sake of the world we share in common, we must consider the significance and consequences of our act for our life in common. We cannot forgive with the blindness of love. However, it differs fundamentally from the realist's ethic of responsibility because it is not predicated on a consequentialist morality. For the struggle to settle the meaning of the wrong in the past is not the same as forgetting or 'overcoming' the past. Rather, it seeks to establish a provisional closure, one which acknowledges the persistent claims of the past in the present - and, therefore, the impossibility of any final reconciliation - but which resists the power of the past to determine the possibilities of present.

Moreover, a forgiveness based on respect for the other as co-builder of a common world does not presuppose a shared moral vocabulary or form of life but rather a willingness to entertain the other's point of view. As such it 
is compatible with citizenship in a diverse society. But in contrast to the benign indifference of the liberal, which would reduce forgiveness to toleration, an ethic of worldliness invites those who wronged us to engage with us in a contentious debate about the significance of past events for our life in common. In forgiving we affirm our potentiality to act anew, to establish new relationships. But since this is an inherently free act, its terms cannot be dictated in advance by the demands of justice. The way of political forgiveness does not necessarily follow the logic of right that the political liberal insists on. Rather, the willingness to forgive invites the other to politics. Instead of presupposing community between wrongdoers and wronged, a 'we' is invoked as a matter of faith, in terms of which former enemies might come to a shared understanding of what went before.

\subsection{Amnesty, amnesia and anamnesis}

If the moral achievement of retributive justice is, as Arendt insists, that it holds the individual to account for his actions and refuses to accept excuses such as 'just following orders', this can also be its political failure (EJ: $5 \mathrm{f}$.). For, as Pablo de Grieff (1996: 105) points out, imputing criminal guilt to particular individuals tends to exonerate those implicated in past wrongs as tacit supporters or beneficiaries of an unjust regime. Of course, amnesty is even more likely to obscure political responsibility for past wrongs. Punishment, at least, symbolises a collective condemnation of past wrongs. Amnesty, by contrast, suggests collective forgetting, a failure to take past wrongs seriously at all.

What was interesting in South Africa, however, was that amnesty was linked to reckoning with the past rather than simply wiping the slate clean. As van Roermund (2001: 178) succinctly puts it, amnesty was associated with 'anamnesis rather than amnesia'. The deal of granting amnesty in return for full disclosure of the truth was supposed to provide a way of burying rather than obliterating the past, 'a way of covering that uncovers the meaning of what has happened' (van Roermund 2001: 178). Consequently, a subtle relationship seemed to emerge between the provision of amnesty to perpetrators and the possibility of political forgiveness between ordinary citizens. This suggests that, in certain circumstances, a willingness to forgive 
might sustain a policy of amnesty and, conversely, amnesty might contribute to the possibility of political forgiveness.

So long as state crimes go unpunished what a wrongdoer gets away with is a 'claim of relative superiority' (Hampton 1988b: 134). Failure to prosecute a perpetrator in this way amounts to acquiescence in the message his crime communicated about the inferior social status of the victims. To add insult to injury, when amnesty is associated with forgiveness rather than acknowledged as strategic compromise, it seems that this failure is passed off as a moral achievement. Yet, during a transition to democracy or at the conclusion of a civil war, punishment of state criminals may not be politically feasible due to the kinds of reasons emphasised by realists. For example, military leaders may threaten to overthrow a civilian government that attempts to punish the leaders of the former regime. The relentless pursuit of justice might be self-defeating in such circumstances since it could well return a polity divided by past wrongs to authoritarian rule or civil war. An ethic of responsibility would demand that justice be sacrificed in order to safeguard the establishment of democratic institutions.

While Archbishop Desmond Tutu (1999) sometimes defends the provision of amnesty in South Africa on such grounds, he often also makes a stronger claim that it represents 'another kind of justice'. In contrast to a focus on retribution, restorative justice is centred on repairing relationships. As expressed in the interim constitution: 'there is a need for understanding, but not for vengeance, a need for reparation, but not for retaliation, a need for $u b u n t u$ but not for victimisation' (cited in de Lange 2000: 21). ${ }^{7}$ On this account, amnesty might be justified as a collective act of forgiveness, according to which waiving punishment does not simply sacrifice justice for politically expedient reasons but upholds justice according to the ideal of restoration.

According to Tutu, restorative justice is preferable to retribution, which is akin to revenge. However, as David Crocker (2000) discusses,

\footnotetext{
${ }^{7}$ The indigenous concept of $u b u n t u$ (according to which people should be friendly, hospitable, magnanimous, compassionate, open, and non-envious) was often referred to in South Africa to lend further legitimacy to the Christian ideal of reconciliation.
} 
retribution and revenge are not the same. ${ }^{8}$ Fundamentally, this is because retribution mediates the just demand to punish the wrongdoer with the intervention of an impartial third-party in the form of legal institutions. Although in practice revenge and retribution may go together, we commonly understand that retribution becomes unjust the more it shades into revenge. Indeed, it was to the extent that the post-war Nuremberg trials were perceived to amount to 'victor's justice' (according to which the conquerors exact tribute from the defeated) that they were regarded with cynicism. By contrast, the legitimacy of Nuremberg and more recent attempts to prosecute state criminals in an international court of law depends on the extent to which these are judged to have been impartial (rather than "political", in the realist sense of the word). Retribution is not reducible to revenge, then. Indeed, it is morally preferable to amnesty as a demonstration of a new regime's commitment to upholding the rule of law.

Moreover, Christopher Bennett (2003) argues that just retribution is as fundamental to the restorative ideal of reconciliation as is forgiveness. Bennett, himself an advocate of restorative justice, insists that genuine reconciliation requires the repudiation of past wrongs and this 'should be expressed publicly and institutionally through punishment'. Like apology, atonement and reparation, a willingness to accept just punishment demonstrates that a perpetrator is remorseful, which establishes the possibility of his forgiveness and return to the moral community. Amnesty, then, cannot be justified as a collective act of forgiveness in terms of the restorative ideal of justice because it fails to hold the wrongdoer to account for his actions. Consequently, Bennett insists, there is no 'third way' between the justice of retribution and the injustice of amnesty. Rather, we are left with

\footnotetext{
${ }^{8}$ Crocker distinguishes retribution from revenge on six grounds: 1) retribution addresses a wrong whereas we may seek revenge on our enemy in response to a slight or unintended injury; 2) retribution is constrained, proportionate to the wrong perpetrated, whereas revenge tends to be insatiable, limited neither by prudence nor a sense of just desert; 3 ) retribution is impersonal and impartial, imposed by a third party, whereas revenge is sought directly by an interested party who is aggrieved by the wrong; 4) retribution takes no satisfaction in seeing the other brought low (beyond the pleasure of seeing justice done) whereas revenge is "sweet"; 5) retribution is principled - it is committed to upholding a general rule or norm rather than being a response only to this particular injury; 6) retribution rejects collective guilt - it can only be dealt to individuals who are directly responsible for their own actions (or inactions). By contrast, a vengeful attitude tends to impute blame collectively and we may exact revenge on an enemy by harming his (innocent) fellow group members.
} 
a stark choice between the moral reasoning of the liberal that being true to the past requires retribution and the political willingness of the realist to forget past wrongs in order to ensure the survival of the political association. Though the compromise of the realist may sometimes be called for, we should recognise this for the sacrifice of justice that it is rather than pass it off as another kind of justice.

But reducing the question of amnesty to these terms seems to miss something important about what was aspired to in South Africa. This may not have amounted to another kind of justice, but it did appear to involve more than just Realpolitik. When Babalwa Mhlwuli appeared before the TRC and said 'We want to forgive, but whom should we forgive?', she did not demand reasons why she ought to forgive but sought grounds on which it was possible to forgive. This attitude of wanting to forgive, according to van Roermund (2001: 180), 'anticipates and eradicates the point where doing justice could become obstructive for civil peace. It steers away from the pitfalls of fiat justitia, perat mundus' (Let justice be done though the world may perish). In South Africa, it seems, it was not the acknowledgement of wrongdoing by perpetrators that established the possibility of forgiveness. Rather, it was the disposition to forgive, a willingness on the part of those wronged to defer the right to just retribution, that cleared the way for perpetrators to publicly disclose the wrongdoing they were involved in (van Roermund 2001: 179-183).

In South Africa, amnesty was not conditional on a perpetrator showing remorse but, rather, on his making a full disclosure of the truth and demonstrating that his wrong was associated with a political objective. This meant that the amnesty commission had to judge applicants both as individuals who committed isolated crimes and as members of a class who were pursuing political objectives. As Veitch (2001: 39) writes, judges were called on 'to make an overt judgement about the "political objective" of the offence, and in so doing...necessarily engage a collective meaning for both the offence and applicant's role in its commission' and somehow understand this to 'fit the "full disclosure" unique to the applicant'. It was this effort to make political sense of perpetrator's actions, one that necessarily deprioritised the logic of Right, which linked it with a wider struggle for political forgiveness. For in associating individual acts with political 
objectives, the amnesty process implicated all those on behalf of whom perpetrators claimed to act.

In this context, the truth the TRC sought to disclose was not the truth of the event but the 'truth of memory' (Veitch 2001: 40). The connection between political objective and full disclosure drew the amnesty applicants and the law into a political reassessment of the past, one which demanded a confrontation between actors' self understandings then and now. Being true to the past, in this sense, required both making political sense of how wrongs came to be perpetrated as well as the moral judgement that these acts were wrong. By making political sense of past wrongs those social meanings that structured the perpetrator's actions and that make his choice of evil comprehensible come to the fore. To be sure, granting amnesty based on such an understanding could not amount to a collective act of forgiveness. Yet, the amnesty process appeared to be sustained (in part, at least) by wanting to forgive. Similarly, the truth-telling associated with amnesty made way for a wider process of political forgiveness by engaging the collective meanings perpetrators shared with ordinary citizens.

The South African experience suggests that, in order to conceive reconciliation politically, we need to reverse the order of our moral thinking. In certain circumstances, it may be that forgiveness 'makes politics itself possible' (Elshtain 2001: 53). Rather than achieving closure by restoring social harmony, wanting to forgive creates a space for truth-telling and the assumption of political responsibility. As such, it opens the possibility of an interpretative struggle over the significance of past wrongs and the terms of political association. Political forgiveness is not so much oriented to restoring wrongdoers to a moral community but to disclosing the commonness of a world that is constituted by diverse and possibly incommensurable perspectives. As such, a disposition to forgive, indeed, describes an attitude with which we might come to politics, one which might enable us to work out and sustain a good we hold in common. However, it is not conditional on a prior moral consensus and recognition of common political authority. Rather, political forgiveness opens the way to their realisation.

And yet, although political reconciliation must be sustained by the willingness to forgive, the risk remains that we may find ourselves 
confronted by the unforgivable (see Govier 1999). Referring to Kant, Arendt describes offences to human society that are so grave they transcend our power to either forgive or punish them. To the perpetrator of such 'radical evil,' which resists human reckoning because it breaks down all standards of judgement, Arendt argues, 'we can only repeat with Jesus: "It is better for him that a millstone were hanged about his neck, and he cast into the sea"' (HC: 241). Indeed, it seems that Arendt eventually judged the crime of Adolf Eichmann in these terms, her description of his intentions and motivations in terms of the 'banality of evil' notwithstanding (see Bernstein 1996: 152f.).

According to Arendt, because Eichmann had lost the ability to tell right from wrong due to sheer thoughtlessness, he could not be held responsible in modern legal terms. In this context, she invokes a more ancient, elementary sense of justice. Unable to resist adding her own judgment to that provided by the court she declares that because Eichmann supported and carried out a policy that sought to rid the earth of a category of people 'we find that no one, that is, no member of the human race, can be expected to want to share the earth with' him (EJ: 279). For this reason, she insists, Eichmann had to hang. As terrible as Eichmann's crime was, I do not share Arendt's judgement that a human being could be so beyond redemption that his execution by a state is justified. Nevertheless, the possibility that past wrongs may turn out to be unforgivable is a risk that political reconciliation must accept. But to the extent that reconciliation is political, the unforgivable must be understood as a future possibility, a sign of the failure of our inter-action rather than a given that determines our relation to the other from the outset.

When confronted by the prospect of the unforgivable, the possibility of reconciliation is likely to depend significantly on the willingness on the part of a brave few to forgo the certainty of moral reason for the risk of politics. Rather than insisting on first establishing the moral truth of what went before, wanting to forgive might establish a context within which it is possible to contest the significance of past wrongs for the world that lies between former enemies. As such, an offer of political forgiveness might create a space for those implicated in grave wrongs as bystanders and beneficiaries to acknowledge these wrongs and assume political responsibility for them. 


\section{Responsibility}

Political reconciliation is initiated, as we saw in chapter six, by the invocation of a "we" that is not-yet. By interpreting the present as a moment in which this "we" might be understood (in retrospect) to have originated, constitution conditions an awareness of the frailty and contingency of community. Because the disclosure of a world in common depends on engaging in collective action, reconciliation unavoidably entails the risk of politics. Yet this cannot be dispensed with by the institutional guarantees of a formal constitution. Rather, as Arendt insists, there is ultimately nothing to guard against the risks of action but the practices of promising and forgiving. By establishing shared expectations for the future, promising allows political conflict to be cast as potentially resolvable. Wanting to forgive helps sustain a reconciliatory politics, as we saw in chapter seven, by refusing to allow history to determine our relation to others in the present. Insofar as frailty and natality provide grounds for forgiveness in politics, the possibility of reconciliation does not depend on first establishing a consensus about the moral significance of past wrongs. Rather, wanting to forgive opens the way for the transgressors to assume responsibility. If constitution establishes a space for a reconciliatory politics in terms of which it is possible to countenance forgiving one's enemy, wanting to forgive provides an opportunity for the acknowledgement of past wrongs and acceptance of political responsibility by those implicated in wrongdoing.

In this chapter, I consider in what sense ordinary citizens should be held collectively accountable for state wrongs and how they might assume political responsibility for the wrongs they are implicated in as tacit supporters or beneficiaries of an unjust regime. I take Karl Jaspers' [1947] influential book, The Question of German Guilt (hereafter QG), as a starting point for examining these issues in 8.1. In order to establish the extent and limit of collective responsibility, Jaspers differentiates political guilt (which 
may be incurred due to membership in a group) from criminal, moral and metaphysical guilt (which relate strictly to the individual as autonomous agent). As I discuss in 8.2, Arendt agrees that collective responsibility should be clearly distinguished from moral and legal guilt. But she also articulates a richer account of how political responsibility might be assumed. In its worlddelimiting moment, political responsibility is connected with care for the world, with acknowledging our implication in injustice as a consequence of our worldly inter-action. In its world-rupturing moment, it entails a responsiveness to the play of the world, a willingness to accept the risks of action in the hope of realising a world in common with our former enemy. Following from this, Arendt disagrees with Jaspers as to the value of the sentiment of shame in politics (8.3). While for Jaspers, shame provides an impetus to purification of the polity, Arendt suggests that such a sense of vicarious guilt is a potential vice in politics. In 8.4, I consider whether political responsibility for past wrongs fades with the passage of time in the context of the debate over whether indigenous peoples in Australia are owed an official apology. ${ }^{1}$

\subsection{Guilt and denial}

"You are guilty." In 1945, these words appeared on posters around towns and cities in occupied Germany as part of the denazification program instituted by the Allies. Above the words was an image of Buchenwald. Alongside them, an accusing finger pointed at the observer. While rumours of the death camps were deliberately circulated by the Nazis towards the end of the war, this was, for many Germans, the first confirmation of their truth. Consequently, the charge of collective guilt was met with widespread indignation and cynicism (QG: 47; Arendt 1950: 348-349). How could ordinary people be held responsible for wrongs from which they were far removed, which were perpetrated in distant places of which they had only the vaguest knowledge?

1 This chapter is based on my (2001) article, 'Guilty subjects and political responsibility', Political Studies 49(4): 749-766. 
Despite the difficulties of talking about collective responsibility within a liberal political vocabulary that cherishes the moral autonomy of individuals, it is commonly presupposed that acceptance of collective responsibility for past wrongs is a necessary condition for political reconciliation. In order to underscore a break with the past and secure a future in which such wrongs will not be repeated, what seems to be required is sincere public expression of remorse and widespread personal realisation of collective implication in past wrongs. Yet, like many Germans in 1945, citizens who find themselves identified as 'guilty' within the terms of political reconciliation often respond with denial.

In what sense, then, can ordinary citizens be held collectively responsible for wrongs that were perpetrated in their name but which they did not commit and may not even have supported? Jaspers and Arendt agree that all citizens, by virtue of their membership in a political community, are collectively responsible for reparations to those wronged by their state. This liability, however, does not imply moral blame because it is imputable on the basis of association rather than the actions and intentions of each person. Arendt and Jaspers thus implicitly draw a distinction, which is now common place, between collective responsibility and collective guilt (e.g. see Habermas \& Michnik 1994: 7). Attribution of collective guilt is unjust because it imputes blame without regard to the actions or intentions of individual group members. Attribution of collective responsibility, by contrast, is just because it refers only to a liability predicated on the duties of citizenship.

Jaspers differentiates this political responsibility without personal blame from criminal, moral and metaphysical guilt. He insists that Germans are collectively responsible for reparations for crimes perpetrated by their state, regardless of their particular involvement. A people must 'answer for its polity' (QG: 61). He identifies several reasons why it is just to hold the German people collectively responsible in this sense. Since members of a polity accrue common benefits by virtue of their association, they are similarly liable for common sanctions (QG: 40). To the extent that a state institutionalises common decision making structures, citizens can be collectively held to account for the outcomes of these (QG: 60). Moreover, even in the absence of such structures, denizens of a state are in some sense collectively responsible for the 'atmosphere of submission' on which a 
repressive regime depends to maintain its power (QG: 78). The corollary of this limitation of collective responsibility to the political realm is that it is unjust to attribute criminal, moral or metaphysical guilt to a 'people'. To do so would be to disregard the heterogeneity of the population and to fail to recognise its members as autonomous moral agents (QG: 40-42).

In differentiating between these four kinds of guilt, Jaspers' principal concern is to facilitate the 'moral and political self-clarification' of his conationals (Rabinbach 1996: 20). In particular, he wants to debunk the view that the prosecution of state-criminals and payment of reparations exonerates the population. This leads him to a cursory treatment of political and criminal guilt, which he discusses in order to demonstrate that prosecution of war criminals and the demand for reparations by the Allies do not necessarily amount to "victor's justice". Rather, the post-war measures imposed on Germany are just to the extent that they seek retribution not revenge, restitution not tribute. What criminal and political guilt have in common is that they are subject to public judgement and sanction. Just as the criminal must answer for his crimes, a people must answer for its polity.

In contrast to criminal and political guilt, however, moral and metaphysical guilt are a matter of individual conscience (QG: 39). Moral guilt might be incurred through conforming with an immoral system out of selfinterest, showing indifference to the suffering of others, failing to resist a criminal regime, genuflecting to its values while knowing them to be immoral, giving tacit support to a regime, trying to see something good in it, or deceiving oneself that one could change the system from within (QG: 6370). One might become guilty through passivity, an unwillingness to risk one's career or even one's life in defence of what one knows to be right. But there can be 'no moral obligation to sacrifice one's life in the sure knowledge that nothing will have been gained' (QG: 71). Impotence mitigates against moral responsibility.

However, even if an individual did all that could be 'reasonably expected' to prevent the perpetration of grave wrongs, as witness to such crimes he is likely to be haunted by a sense of what Jaspers calls metaphysical guilt. This kind of guilt stems from a failure to show 'absolute solidarity' with others regardless of our particular relation to them (QG: 32 ). 
Even if intervening to prevent a crime against another would almost certainly have resulted in one's own futile death, a sense of guilt might nonetheless arise from the self knowledge that one chose survival rather than staking one's life on being together with others. The survivor knows that he would rather live in a world where such crimes are possible than die in defence of a world in which they would not be. Although 'reasonable expectation' mitigates against moral culpability, it fails to alleviate the guilt of survivors because the certainty that we did all that could be done is impossible in the face of those who sacrificed their lives. The only evidence that could satisfy the truth of what we want to believe would be our own death (see also Morris 1976: 132-135).

While moral and metaphysical guilt are not collectively imputable in the sense of political guilt, the implication of Jaspers' analysis is that all Germans are morally and metaphysically guilty, to varying degrees, by virtue of their individual actions and inactions during the Nazi regime. That Germans are collectively liable for reparations is taken for granted by Jaspers. The pertinent question, for him, is to what extent each member of the polity should feel co-responsible (QG: 61). Publicly, assuming responsibility for wrongdoing depends on state reparations and punishment of the perpetrators. But the deeper process of purification that Jaspers advocates depends on the realisation of moral and metaphysical guilt by ordinary Germans in communication with one another. Just as the realisation of moral guilt brings insight, which involves 'penance and renewal' and leads to 'inner development', so recognition of metaphysical guilt leads to 'transformation of human self-consciousness before God' (QG: 36). The spreading consciousness of individuals of their personal implication in Nazi crimes will lead to a widening and deepening sense of co-responsibility and, consequently, to a transformation of the 'collective morality contained in the ways of life and feeling' of the German polity (QG: 79).

Jaspers differentiates German guilt, then, both to facilitate the realisation of individuals of their co-responsibility for Nazi crimes and to define the limit of public judgement. His distinction between political/criminal guilt and moral/metaphysical guilt is predicated on the liberal distinction between public and private since it circumscribes a private sphere of personal accountability that is not subject to public-legal 
jurisdiction. As the experience of 'lustration' in Czechoslovakia attests, it is important to limit the imputation of guilt in this way in order to protect individuals from unjust punitive state measures (or "witch hunts") following transition to a new regime. ${ }^{2}$ As Anson Rabinbach (1996: 21) points out, however, it also leads Jaspers to a somewhat thin account of political responsibility. To be sure, he emphasises the importance of public communication between particular individuals for coming to a realisation of moral and metaphysical guilt and, hence, a sense of co-responsibility. Yet this remains a personal process of self-realisation. Aside from the general obligation to make reparations, Jaspers hardly considers how this coresponsibility might be assumed politically.

\subsection{Good men and good citizens}

Arendt's ethic of worldliness furnishes a more robust conception of political responsibility than Jaspers can provide. ${ }^{3}$ Like Jaspers, Arendt (1987: 43-46) insists on a clear distinction between collective responsibility (which is always political) and personal responsibility (which is legal or moral). Political responsibility is distinct from personal responsibility in that it is vicarious and involuntary. It is vicarious because a citizen may be held liable for things he or she did not do and it is involuntary because it results from his or her membership in a political community. Although individuals may be held liable for acts that are involuntary and vicarious, they cannot be blamed for them. While liability is transferable between moral agents, blame is not. Because guilt always involves blame, it is a moral error to attribute it collectively.

\footnotetext{
2 "Lustration" referred to the purging of Communists and collaborators of the former regime from public office and state employment following the transition to democracy. However, because the main source of evidence was the files kept by the secret police of the former regime, their use often had the effect of continuing the unjust practices of the past into the present (see Teitel 2000: 98f.).

${ }^{3}$ According to Young-Bruehl (1982: 216), Arendt and her husband Heinrich Blücher were concerned that Jaspers' text was 'not political enough'. These concerns are reflected in a letter to Jaspers in which Arendt wonders whether the concept of metaphysical guilt should be predicated on the less 'absolute' and more worldly solidarity that ought to exist among citizens of a republic rather than Christ-like love (Arendt \& Jaspers, 1992: 54).
} 
While Arendt follows the same line of reasoning as Jaspers in defining this limit, she emphasises the other side of his moral point. She is less concerned that the imputation of collective guilt unjustly disregards the possible innocence of some individuals than that it diverts attention from the particular culpability of many others. The identification of all as guilty obscures the fact that state wrongs are possible only as a result of the particular actions (and inactions) of individuals. Consequently, as Arendt (1987: 43; 1964: 185) often puts it, 'where all are guilty none is' (see also JP: 230; EJ: 278; CR: 162). The generality of a theory of collective guilt has the effect of making judgement of particular acts and events superfluous. To confess collective guilt is devoid of all risk because it attempts to account for every event and deed in a single pronouncement. Collective blame suggests the inevitability of events, retrospectively removing outcomes in human affairs from the influence of individual action and attributing them to a national character or cultural predisposition (EJ: 297). Acknowledgement of collective guilt, then, actually amounts to a plea of personal and political irresponsibility.

This is especially pernicious because it was precisely a widespread abdication of moral and political responsibility that made the death camps possible. This was manifest both in an unwillingness to judge and a widespread personal feeling of being superfluous (OT: 311f.; EJ: 114; Arendt, 1964: 205). Arendt singles out bureaucracy and ideology as modern inventions that relieve individuals of political responsibility. Bureaucracy does so by evaluating individual actions according to their efficiency in performing a function rather than on the basis of the ends they seek to realise. Individuals are discouraged from evaluating these ends because they lack the expert knowledge deemed necessary to properly do so (OT: 214). In this way, bureaucracy leads to 'rule by nobody' (HC: 40; EJ: 289). Similarly, ideologies relieve individuals of the capacity to judge by attributing outcomes in human affairs to processes beyond the influence of spontaneous human action. Individuals relinquish responsibility by submitting to a 'tyranny of logicality' that rejects as anomalous all experience that contradicts an internally coherent system of thought (OT: 465).

Facilitated by bureaucracy and ideology, abdication of political responsibility enabled "normal" individuals like Adolf Eichmann to become 
functionaries in the Nazi regime (EJ: 276). Good family men were able to perform their murderous duties efficiently and without comprehending the gravity of their wrong doing because they perpetrated crimes in their professional capacity and not out of personal inclination. Because they related to the public sphere as a means to secure their private happiness, they failed to draw a connection between their private and public selves. In their public roles they acted according to the values of the job holder (security and efficiency) rather than those of the citizen (judging and acting for the sake of the world) (JP: 231-234). Since they were unable to transcend the subjectivity of their private lives, they failed to recognise the evil of their deeds, their impact on the world (HC: 57; Arendt 1964: 205; EJ: 25 f.). Importantly, this political irresponsibility, which made the crimes of the Nazis possible, is not peculiar to Germany but an 'international modern phenomenon' (JP: 233). Abdication of political responsibility is symptomatic of the modern condition of world-alienation, which arises when members of a polity cease to value the world-disclosing potential of politics (HC: 208f., 248-257).

As we saw in chapter four, it is against these anti-political tendencies of modern society that Arendt affirms her ethic of worldliness. The object of political responsibility, on this account, is the world we share with others, which precedes and succeeds our own transient lives. Whereas moral responsibility is associated with the integrity of the self, political responsibility is associated with care for the frail space of appearances. As discussed in 4.3, Arendt draws out this distinction between moral and political responsibility in terms of the contrast between the good man and the good citizen. Moral considerations are self-regarding in that they are guided by the kind of person one is or wants to be. By contrast, political considerations are not so much concerned with whether one is good as whether one's actions are good for the world in which one lives. For the good man, it is 'better to suffer wrong than to do wrong' because it is 'better for me to be at odds with the whole world than, being one, to be at odds with myself' (Arendt 1987: 47; TMC: 438-446). By contrast, the good citizen places his city higher than his soul. He cares more for the world than for his self. He knows that 'on the day that you must leave the world it will be of greater consequence to leave behind you a better world than to have been good' (MDT: 236). 
Moral responsibility, as articulated in relation to the Kantian ideal of autonomy, is primarily negative. It enjoins us to avoid wrongdoing and establishes our accountability for consequences of actions that may be imputed to us as intending subjects. We abide to live by the law that we give to ourselves as rational moral agents and seek to repair harms that we knowingly bring about when we fail to uphold this law. By contrast, political responsibility requires us not only to avoid wrongdoing but to preserve and look after the world. As such, it is associated with the virtue of prudence, an attitude of care for what is fragile. It enjoins us to prevent wrongdoing and to assume responsibility not only for actions of which we may be said to be the authors but for the unintended consequences that result from our interaction with others, the processes in which we become entangled not just as doers but as sufferers. This 'vicarious responsibility' is, according to Arendt (1987: 50), 'the price we pay for the fact that we live our lives not by ourselves but among our fellowmen, and that the faculty of action...can be actualised only in one of the many and manifold forms of human community.'

In contrast to the economy of rights and duties according to which we are morally accountable, political responsibility makes a claim on the individual for 'an on-going responsiveness to the world, including a need to respond for what has been done' (Williams 1998: 946 - emphasis added). ${ }^{4}$ It is unpolitical to accept responsibility only in terms of the first (albeit somewhat reductive) moral sense of accountability. For it limits responsibility to that part of our selves over which we are masters. It neglects the extent to which 'who' we are as agents in the world is beyond our control because it emerges from our inter-action with others. As Zenon Bankowski (2002) writes, if conceived exclusively in these terms, 'remorse would be repairing my timeless ahistorical self...we would be saved as long as we purify our interior self and our intentions are right'. By contrast, political responsibility is predicated on an acknowledgement of the extent to which who we are depends on our historical relation to others, the way we are

\footnotetext{
${ }^{4}$ As Ricoeur (2000: 29) writes, 'if we follow Emmanuel Levinas, it is from others rather than from our inner conscience or heart of hearts that the moral injunction is said to proceed. By becoming the source of morality, other people are promoted to the rank of the object of concern, in respect of the fragility and vulnerability of the very source of the injunction...one becomes responsible for harm because, first of all, one is responsible for others'.
} 
enmeshed in the stories enacted in the world irrespective of our particular motives and intentions.

Yet, conceiving political responsibility in terms of care for the fragile world we share with others seems to implicate us in every injustice. It extends our responsibility indefinitely in both time and space, according to the boundlessness of action, and so threatens to overwhelm us. As Ricoeur (2000: 33-34) observes, 'simply neglecting the side effects of an action would render it dishonest, but an unlimited responsibility would make action impossible'. Faced with this difficulty, it is important to recognise, with Ricoeur, the close connection between care for the world and the virtue of prudence. He understands prudence not just in the weak modern sense of prevention but the ancient virtue of phronesis, which I earlier referred to as reflective judgement (4.3). Political responsibility in this sense requires us to act in the broken middle of time, to find the 'just measure' between fleeing responsibility for actions of which we are not the authors and the paralysis that ensues from recognition of an infinite responsibility. In this context, following Bankowski (2002), accepting responsibility for the wrongs in which ordinary citizens are implicated would be 'not about stopping history and starting again' but 'living through the consequences of what has happened in the present'. We will examine further the implications of this in 8.4, but first we must consider to what extent a collective sense of atonement and remorse ought to animate a reconciliatory politics.

\subsection{Shame and sentimentality}

While the first government of the Federal Republic of Germany accepted a liability for reparations, it is often argued that it tended to 'instrumentalise' reparations as a means to 'normalise' its relations with the West (Rabinbach 1986: 5). Through reparations the new regime sought to settle accounts once and for all, to forget the past and move on. Chancellor Adenauer's reluctance to acknowledge collective guilt on behalf of the citizens he represented reflected the inability of most Germans to properly realise their implication in Nazi crimes (Olick and Daniel 1997: 928; Reuter 1990: 174-5). This was reflected in the 'silent' coming to terms with the past in the Federal Republic and the slogan of 'inner emigration', the claim by many Germans that they 
had always been 'inwardly opposed' to the regime (see EJ: 126-127). The Nazi past became a taboo subject amidst the post-war prosperity, the sense of responsibility of ordinary citizens exculpated by the myth that 'the barbarism of National Socialism had affected only a relatively small percentage of the country' (Adenauer quoted in BPF: 252).

According to some commentators, Jaspers' influential book contributed to this cultural milieu because the distinction he draws between moral and political responsibility is too neat. Rabinbach (1996: 23-24) argues that this legitimised the government's emphasis on reparations and official declarations in place of what could have been more effective and meaningful political attempts to acknowledge the truth of the Nazi past. Moreover, Dagmar Barnouw (1990: 159) insists, it resulted in the displacement of a collective reckoning with the past to the private sphere, where it became a psychological issue of personal healing rather than a properly political concern. ${ }^{5}$

If Jaspers' text did contribute to the failure in post-war Germany to openly reckon with the legacy of grave state wrongs, however, this was not due to a too rigid distinction between morality and politics. As we saw in 8.1, Jaspers does differentiate moral guilt from political responsibility in order to determine the limits of public sanctions. But he does not understand morality and politics as autonomous from each other. On the contrary, he insists that 'there can be no radical separation of moral and political guilt' (QG: 77). Like Taylor, Jaspers emphasises the dialogic relation of the moral self to the political community (QG: 33-34). The ethos of a political community arises from the 'moral everyday life of individuals' and the morality of individuals is, in turn, formed by the ethos of a political community. While moral guilt is strictly personal, there is nevertheless a 'collective morality contained in the ways of life and feeling, from which no individual can altogether escape and which have political significance as well' (QG: 78-79). Indeed, this collective

\footnotetext{
${ }^{5}$ These objections are difficult to reconcile with Arendt's description of Jaspers as one of those rare philosophers who unequivocally affirms the public realm and who possesses a 'political mentality par excellence' (MDT: 74, 79). Moreover, they seem to elide what Rabinbach (1996: 20) himself recognises as Jaspers' over-riding theme, 'the renewal of a German polity through communication'. Given Jaspers' Kantian insistence on the importance of publicity and communication for a healthy political life, his alleged contribution to the guilty silence of the post-war years seems unlikely.
} 
morality is prior to the political, on Jaspers' account, because it enables and sustains political freedom.

Jaspers does not radically separate morality and politics, then, but tends to reduce the political to the moral. This is apparent in the theological vocabulary of guilt, atonement, purification and grace in which he discusses the realisation of political freedom and democracy in Germany. For Jaspers, 'without purification of the soul, there is no political liberty' (QG: 121). While moral guilt cannot be determined from without, when felt from within it institutes 'an inner upheaval which seeks to realise political liberty' (QG: 77). In this way, the spreading consciousness of moral guilt leads to the transformation of the moral-political community. In order to trace the relation between the sentiment of guilt and the realisation of political freedom, Jaspers tempers his initially clear distinction between moral and political guilt. Individuals need not, after all, be directly implicated in particular wrongs in order to experience an 'inner upheaval'. Through sympathetic identification based on a shared cultural tradition, individuals may appropriately feel co-responsible for wrongs they neither perpetrated nor supported. Indeed, the fact of being German (of 'life in the mother tongue') means, for Jaspers, that he feels co-responsible for crimes perpetrated by his compatriots 'in a way which is rationally not conceivable, which is even rationally refutable' (QG: 80). He likens this feeling of coresponsibility to that which we feel for the deeds and misdeeds of family members. ${ }^{6}$

The sense of co-responsibility Jaspers refers to is commonly referred to as shame in contemporary debates about political reconciliation (e.g. Ignatieff 1996: 117). While it is irrational to feel guilt for things we have not done ourselves, it is often argued, we may reasonably feel shame due to our

\footnotetext{
${ }^{6}$ Paradoxically, Jaspers articulates the foundation of a post-war German identity in terms of the realisation of a universal citizenship predicated on the ruins of a shared tradition. For Jaspers, the destruction of Germany means that he is able to feel 'for the first time uninhibited as a German' (quoted in Rabinbach 1996: 22). The ruin of Germany frees the individual for self-fashioning. Anticipating Habermas' advocacy of 'constitutional patriotism', Jaspers embraces Germany's pariah status, the loss of sovereignty and lack of national cohesion as an opportunity for moral and political reinvention. Acceptance of guilt should become a 'fundamental trait of...German self-consciousness' (QG: 119). Jaspers thus made an important intellectual contribution to the post-war 'self-image and ideal of a nationless and cosmopolitan Germany' (Rabinbach 1996: 17).
} 
association with wrongdoers. Just as we may feel pride in the achievements of family members or co-nationals, so it is proper to feel ashamed when their actions reflect badly on us. Unlike guilt, the sentiment of shame does not presuppose direct wrongdoing but rather 'moral taint', which derives not from a sense of what one has done but from who one is (see May 1991: 239; Manderson 1998: 237f.). Whereas guilt refers to individual moral agency and issues from our private conscience, shame refers to our identification with others and arises from our concern with how we appear to others, our sense of honour (Morris 1976: 134; Little 2001: 207).

While 'guilt is often limiting in that it focuses on individual acts of wrongdoing' writes Drusilla Modjeska (2000: 161), 'shame can be a spur back into...community, by the recognition of forces much greater than our small guilty selves'. According to Raimond Gaita (1999: 99), pride and shame are 'fundamental to the kind of fellowship that makes community possible'. In his view, shame is necessary for the proper acknowledgement of one's implication in state wrongs. Shame is not merely an 'emotional addition' to recognition of wrongs perpetrated in one's name but, rather, is 'the form of that recognition' (Gaita 1999: 92). It is a sense of such shame that Chancellor Willy Brandt dramatically communicated when, during his visit to Poland in 1970 , he fell to his knees before a memorial to those who died in the Jewish ghetto in Warsaw. Brandt's gesture is often contrasted approvingly against Adenauer's post-war silence. ${ }^{7}$ Certainly, the sense of shame that often accompanies the efforts of those on the Left of politics to address a legacy of grave wrongs appears preferable to the denial of guilt typical of those on the Right. However, as Arendt warns, there is also a danger that the avowal of shame in politics may lapse into a kind of sentimentality that actually entails a further evasion of political responsibility. ${ }^{8}$

\footnotetext{
${ }^{7}$ According to Geiko Müller-Farenholz (1997: 32-33), for instance: 'That sudden gesture had been an act of surrender to the shame Germany felt with regard to the Polish people and the Jews among them. Having been a resistance fighter against Hitler, exiled in Norway, Brandt could easily have exonerated himself from any guilt of the Nazi regime. But he vicariously identified himself completely with the history of his nation, and so took it upon himself to humble himself so that the victims' honour should be restored.'

${ }^{8}$ As Graham Little (2001: 199) observes, 'To the Right, admitting guilt at all is a defeat, it's giving in. Confession hands your enemies a stick to beat you with. But Left-wing concern guilt announces itself: it's a profession, not a confession'.
} 
Arendt is as concerned as Jaspers that ordinary Germans should come to a realisation of their personal implication in the crimes of the Nazi state. On a return visit to Germany in 1950, she was appalled by 'a deep-rooted, stubborn, and at times vicious refusal to face and come to terms with what really happened' among the populace (Arendt 1950: 342). However, in contrast to Jaspers, she considers the vicarious feeling of guilt (which we recognise as shame) to be detrimental to the realisation of political freedom (Arendt 1987: 43-44). In particular (writing some years later), she is critical of those members of the radical student movement in Germany who occasionally indulge in 'hysterical outbreaks of guilt feelings'. According to Ian Buruma (1994: 25), the 'overriding moral aim' for the '68ers' was 'to be utterly different from their parents, to crack their guilty silence'. But, in Arendt's view, they are not 'not staggering under the burden of the past, their fathers' guilt' but 'trying to escape from the pressure of very present and actual problems into a cheap sentimentality' (EJ: 251). ${ }^{9}$ Arendt's objection to this sort of guilty politics is informed (as we saw in 8.2) by her recognition that collective guilt obfuscates individual culpability. However, she is also concerned that the sentiment of guilt denatures politics when it serves as a basis for association, motive for action, or standard of judgement in public life.

As Feinberg (1991) and Gaita (2000: 93) recognise, the feeling of shame or vicarious guilt requires that we identify with our compatriots. By virtue of a common identity, individuals feel a sense of shame that leads them to act politically in order to ameliorate past wrongs. However, as Arendt (1987: 44) writes in her response to Feinberg, such sympathetic identification would mean that 'the cry "We are all guilty" is actually a declaration of solidarity with the wrongdoers'. As with the solidarity of victims based on shared suffering, a solidarity of perpetrators based on shared guilt or shame is an unpolitical form of togetherness. This is because it is based on an imagined natural bond (the nation as family) rather than the artificial institutions and shared interactions that constitute a world in common. A shameful solidarity seeks to avoid the risk of politics. Rather than leaving who "we" are indeterminate, open to question by others, it seeks to redeem the identity of

\footnotetext{
${ }^{9}$ She is similarly dismissive of those 'good white liberals' in the United States who 'confess to guilt feelings with respect to the Negro question' (Arendt 1987: 43; CR: 162).
} 
the wrongdoers by demonstrating good intentions in the present. Moreover, it tends to both occlude differences within a 'perpetrating community' and to exclude different others. Consequently, those who do not accept this shameful identification might withdraw from politics altogether. ${ }^{10} \mathrm{By}$ implication, if reconciliation is conditional on a prior shameful acknowledgement of responsibility for past wrongs, as Gaita (2000: 92) insists it should be, this may prevent many (those in denial?) from being drawn into a reconciliatory politics in the first place.

There is a further danger that when guilt or shame motivate political action they will become distorted into a sentimentality that entails a peculiar insensitivity to those who have been wronged.11 As Morris (1976: 99-100) observes, the feeling of guilt is associated with suffering. We feel bad because we have hurt another whom we care about ('their being pained pains us') and because we have become alienated from this other person. The suffering associated with guilt is, therefore, a mark of one's care for others. One takes satisfaction in feeling guilt, for this is part of the suffering that one deserves for having unjustly hurt another. Yet, when the sentiment of guilt is made a virtue in politics, the self-satisfaction that comes from feeling bad may be perverted by the demands of public life into a moralism that is detached from the original object of concern. Because it is a sentiment, guilt (like compassion) can be 'enjoyed for its own sake' and this can quickly 'lead to a glorification of its cause' (OR: 89; EJ: 251). Guilt becomes anti-political when it encourages actors to turn away from the worldly activities of persuasion and compromise to assert the absolute validity of moral truth (OR: 86-87).12 Moreover, when publicly expressed in relation to a whole category of people it fails to comprehend these wronged others in their singularity (OR: 85). Rather than responding to the particular and diverse experience of those who

\footnotetext{
10 As Margaret Gilbert (2001: 227f) observes, identification with a group does not in itself establish a political obligation or provide a justification for whether one ought to feel remorse for what "we" did. Rather, it raises the question of justification.

11 As George Kateb (1984: 25-29) discusses, Arendt finds the ostensibly virtuous moral sentiments of love, goodness, conscience, compassion and pity to be potential vices in politics. Because moral sentiments are inherently self-regarding they tend to denature political action and speech. To Kateb's list we ought to add guilt.

12 While insisting that guilt and moral sentiments in general are anti-political, Arendt does not advocate a rationalistic, emotionless politics (CR: $160 \mathrm{f}$.). Indeed, an inability to be moved is as deleterious as sentimentality in politics (Arendt 1950: 342).
} 
have been oppressed, a guilty politics tends to represent the victims as an undifferentiated mass of sufferers.

Closely related to the distortion of shame into sentimentality is the problem that a guilty politics may lead to a search for pure motives and intentions among wrongdoers rather than an engagement with those wronged in the risky business of realising a world in common. When guilt is publicly and freely professed, the sincerity of the actor becomes questionable (OR: 85; HC: 73). Remorse often rings true in the confession box, rarely from the soap box. Given the performative quality of action, the demand for pure motives in the public sphere may lead to a disastrous politics of selfenactment (demonstrating that one's guilt is heartfelt) and unmasking (exposing those who are not sufficiently remorseful) (OR: 98-109; see Villa, 1999: 137-141). This has been evident in Germany, for instance, where there is considerable pressure for political actors to demonstrate that they are properly betroffen when speaking of the Nazi past. Ian Buruma (1994: 21) explains that to be betroffen is 'to be speechless'. Moreover, it 'implies an idea of moral purity. To be betroffen is one way to "master the past", to show contriteness, to confess, and to be absolved and purified'. However, a public expectation of such sincere expression means that utterances about the past become vulnerable to being questioned according to the true motives of the actor, which are veiled by his words. The demand for the expression of sincere remorse shifts the emphasis of political life away from contesting and debating the significance of past events towards conforming to a ritualistic mode of behaviour intended to convey that an actor has his heart in the right place. ${ }^{13}$

Contrary to Jaspers, Arendt's scattered reflections on the sentiment of guilt in politics suggest that we should be wary of affirming guilt (or its

\footnotetext{
13 This was evident, for example, in the hysterical reaction to Phillipp Jenninger's 1998 presidential address to the Bundestag to commemorate the fiftieth anniversary of kristallnacht. Members of the Bundestag walked out in protest during the speech. The foreign press accused him of anti-Semitism and Hitler worship. Two days later he resigned. But, according to Buruma (1994: 243-244), the worst that could be said of the speech, in truth, was that 'it was not betroffen enough...Jenninger's failure, so almost everyone thought, had been to misjudge the occasion, which called for a memorial, not a "sober historical speech."' Jenninger was a victim of a climate of suspicion in German politics, according to which 'Greens, liberals and leftists suspected conservatives of using every opportunity to whitewash the war, and conservatives suspected Greens, liberals and leftists of rubbing German noses in Auschwitz.'
} 
cousin shame) as a wholly benign catalyst for reconciliation. Due to the public nature of politics, there is an inherent tendency to corrupt moral sentiments into vices. To be sure, this kind of sentimentality is just as perverse in our intimate relations with others, and the same temptation to self-enactment is often present in our private lives. However, the public nature of political life increases this temptation in a situation in which not just the integrity of the self but the good of the world is at stake.

A further objection might be raised, with Kateb (1984: 29), that if we exclude sentiments such as guilt and shame as legitimate motives for action we deprive the world of the moral energy they bring to politics. Unless they experience such feelings, how could ordinary citizens ever be motivated to engage in a reconciliatory politics with their former enemies? With Arendt, we might answer that that they might be drawn to politics by the play of the world - the urge for self-disclosure. Yet we need not insist as stridently as Arendt does that there can be no place for shame in politics but only that shame cannot be a precondition for reconciliation. For then it would be unlikely that a reconciliatory politics could ever get off the ground. Just as a way must be found between conceiving responsibility too narrowly in terms of an economy of rights and duties and drawing it too widely so that we are implicated in every injustice, so it seems a compromise must be struck between the denial of guilt characteristic of the Right and a sentimental politics of shame that the Left is often drawn to.

\subsection{Apology, reparation and the passage of time}

Standing in Redfern Park in 1992, Paul Keating (then prime minister of Australia) claimed that the possibility of political reconciliation depends on non-indigenous Australians recognising our responsibility for wrongs perpetrated against indigenous peoples since the time of settlement. 'It was we who did the dispossessing', he declared:

We took the traditional lands and smashed the traditional way of life. We brought the disasters. The alcohol. We committed the murders. We took the children from their mothers. We practised discrimination and exclusion. It was our ignorance and our prejudice. And our failure to imagine these things being done to us.

(Keating 2000: 61) 
The "we" invoked by Keating extends across space to encompass all members of the settler society. But it also extends back in time so that the distinction between "us" in the present and our predecessors in the past is collapsed. Moreover, Keating presupposes continuity between the original act of dispossession and ongoing practices of 'discrimination and exclusion' in the present. Just as the agent of wrongdoing extends across generations, so the history of outrages is compressed into a single 'event' of wrongdoing.

But, in the absence of a shameful identification with our predecessors, how is it possible to account for political responsibility for wrongs from which we seem far removed not only in space but time? If the chorus "what have I done?" often resounds when ordinary citizens find themselves implicated in recent state wrongs (as in Jaspers' post-war Germany), it may be heard even louder when they are held to account for wrongs perpetrated by their past generations. By the time of the Reconciliation Convention in 1997, Keating's Labor government had been replaced by a conservative one. At this time the new prime minister, John Howard, was arguing for 'practical reconciliation' while rejecting the 'black armband' view of history taken by his predecessor. Although Howard professed 'deep personal sorrow' for the suffering of indigenous Australians, he refused to officially apologise for wrongs perpetrated against them. He insisted that:

Australians of this generation should not be required to accept guilt and blame for past actions and policies over which they had no control. But we do have an obligation and responsibility to overcome their legacies for our fellow Australians.

(Howard 2000: 90)

Rather than pointing the finger for past injustices, he argued, we should work to ameliorate the present economic and social disadvantages of Aborigines as part of a wider commitment to providing equality of opportunity to all Australians.

Howard's refusal to apologise was at odds with the end of millennium 'fever of atonement' observed by Wole Soyinka (1999: 90) and others. ${ }^{14}$ In the 1990s a rash of apologies were issued by heads of state for all manner of recent and ancient wrongs. Apparently, Howard feared that an apology

14 See Brooks 1999; Cunningham 1999; Moore 1999. 
might amount to an admission of fault and so establish a legal liability for the payment of reparations to Aborigines who had been removed from their families by the state, the so-called 'stolen generation'. He also wanted to avoid losing votes to the far-right One Nation party. Clearly, many citizens quietly supported Howard's stance. But many others expressed their sense of co-responsibility by participating in public demonstrations around the country on an unofficially declared national "sorry day", by signing "sorry books", wearing black arm bands and partaking in other forms of 'symbolic' politics. But Howard was right to recognise the connection between apology and reparation. Without reparations, reconciliation could only amount, as van Roermund (2002) puts it, to 'public confession, quasi-catharsis and warm feelings.'

In promoting 'practical reconciliation' against the symbolic politics of shame, Howard insisted that we should attend to present harms, no matter who suffers from them, rather than dwelling on past injustices. According to Jeremy Waldron (1992), this view has some merit. For it is often difficult to sustain claims to historic entitlement when these come into conflict with competing claims of equity in the present. Reparative justice is concerned with restoring things to the way they were prior to the wrongdoing, altering present circumstances to the way they would have been were it not for the wrong that was committed. But, given the sheer contingencies of history, it is extraordinarily difficult to establish how things might otherwise have been by use of counterfactual reasoning. Moreover, rectifying an old injustice may require perpetrating a new one. For instance, although the state might do right by some individuals in returning lands stolen from their ancestors over a century ago, it might have to wrong others by repossessing land their family legitimately purchased and have farmed for fifty years.

Furthermore, Waldron argues, claims to historical entitlement based on use and possession (such as those defended by Locke and Nozick) cut both ways. Just as the original claim of entitlement to an object rests on the fact that one has organised one's life around it, so the claim for restitution of the object is weakened by the historical fact of dispossession. The more time has elapsed, the less credible is the claim that one's life is organised around the use or enjoyment of the lost object. Although one's ancestors or community may have had a legitimate entitlement to a piece of land when 
initially dispossessed of it, such a claim may fade with the passage of time as one's involvement with the land becomes less evident. Indeed, this is precisely the logic by which native title was retrospectively recognised in Australia and then found to be extinguished according to the establishment of freehold property and the loss by many Aboriginal peoples of their traditional connection with the land. Given the difficulty of sustaining claims to historical entitlements and the fact that reparation is inevitably concerned with the redistribution of resources, Waldron (1992: 13-14) asks, why we should stop at trying to rectify one particular injustice in the light of the contingent facts of history? Why not redistribute resources more equitably across the whole of society according to universal principles and present needs of individuals? ${ }^{15}$

In an important sense, reparative justice is impossible. We cannot undo the wrongs of the past. Reparations will not bring back the dead. Moreover, to hold present generations responsible for wrongs perpetrated by their ancestors seems like visiting the sins of the fathers upon them. However, as Janna Thomson (2002) argues, although political responsibility to repair wrongs perpetrated by our predecessors is inherently backwardlooking, it does not derive from a duty to the dead. Rather, it is based on the forward-looking practice of promising, which (as we saw in 6.3) is integral to sustaining political community. Our expectation that future generations should abide by morally acceptable promises that we enter into today establishes a responsibility to make reparations for those commitments violated by our ancestors. Our 'authority' to enter into posterity-binding agreements today depends on our willingness to accept the obligation to honour the commitments of our predecessors. As such, recognition of historical obligations does not depend on our identification with the people of the past. But it does require us to see ourselves as 'participants in a transgenerational relationship in which each generation inherits obligations from its predecessors and passes these on to its successors' (Thompson 2002:

\footnotetext{
15 According to Waldron (1992: 27), claims for reparation and claims based on forwardlooking principles of justice often overlap. 'If the relief of poverty and the more equal distribution of resources is the aim of a prospective theory of justice, it is likely that the effect of rectifying past wrongs will carry us some distance in this direction.' Yet, he insists, 'it is worth stressing that it is the impulse to do justice now that should lead the way in this process, not the reparation of something whose wrongness is understood primarily in relation to conditions that not longer obtain.'
} 
18). Our historical obligations arise from our concern that our present commitments be honoured by our successors. ${ }^{16}$ If our promise 'never again' is to hold any weight with our contemporaries and our successors, it must be backed up by the willingness to assume responsibility for wrongs committed by of our predecessors.

In $6.1, \mathrm{I}$ argued that for reconciliation to be political it must also be historical. Our sense of acting in the broken middle of time politicises reconciliation. This is so, I argued, because it conditions an awareness of the contingency and frailty of community since it is only in retrospect that we are able to judge an event as the beginning of something new. This also has implications for our relation to the past and our sense of responsibility for past wrongs. For, as Robert Sparrow (2000: 348) puts it, it sensitises us to the fact that 'the distinction between our past and our present is not necessarily a historically significant one'. From the perspective of the future, what we take to be the 'present' extends both forward and backward in time. Consequently, as Sparrow writes:

What we see as the temporal distance between our actions and those of our predecessors, which distinguishes our actions from theirs, may not be apparent to those looking back on us from the future. Instead they may see us as sharing the same moment, characterised by a continuing dynamic of extermination, dispossession or forced assimilation.

(Sparrow 2000: 354)

From the perspective of our future anterior, our refusal to recognise responsibility for past wrongs is likely to appear as a further and continuing act of injustice toward the ancestors of those against whom an original wrong was perpetrated.

When combined with the knowledge that the significance of events is revealed fully only to the backward glance of the historian, our political concern that future generations should judge us favourably leads to a greater awareness of our ethical predicament. For it encourages us to see the time of reconciliation not only as the 'now' between our own past and future but as

\footnotetext{
16 As such, we are responsible not only for reparations in the case of treaties violated by our predecessors but for 'acts of disrespect' such as the failure to make an agreement as circumstances warranted, forcing another nation to make an unfair agreement or forcibly interfering in or undermining the way of life of another nation (Thompson 2002: 33).
} 
'a historical moment that extends to encompass the entire history of those relations' (Sparrow 2000: 354). And it makes us aware of the risks of action, the fact that 'we may be judged harshly in hindsight' and that 'good intentions may not be enough to preserve us from condemnation' (Sparrow 2000: 357). If we fail to establish a new beginning in the present, the distinction we would like to draw between our good intentions now and the wrongs perpetrated by our predecessors back then will not become historically significant. ${ }^{17}$ Moreover, far from diminishing our responsibility, our sense that we cannot bring back the dead or undo the suffering of the victims means that political responsibility requires not just the acknowledgement of a debt but acknowledgment that this debt can never be repaid (Perrin and Veitch 1998: 228). Reparations are required to acknowledge the debt in the first place. But there is an injustice discernable in the presumption of a moral account that could be settled. Rather, political responsibility means that acknowledgment of our implication in past wrongs remains unsettling.

With Bankowski (2002), I suggested in 8.2, that remorse is unpolitical when we want to stop history to start again. Rather, political remorse entails a willingness to live through the consequences of the past in the present. As such, remorse is not about wanting to purify a tainted identity by demonstrating good intentions in the present. Rather it means acknowledging one's implication in wrongdoing as a consequence of one's entanglement in history. In its world-delimiting moment, political responsibility enjoins us to care for and preserve the fragile web of human relationships that constitute the world. But in its world-rupturing moment political responsibility means engaging with our former enemy in collective action in order to change the circumstances in which we find ourselves. It means assuming the risk of politics in the hope that this world will be disclosed in its commonness. Remorse, then, is not so much oriented to soliciting forgiveness from those we have wronged as inviting them to a potentially agonistic struggle to understand the significance of past wrongs

17 As Sparrow (2000: 351) observes: 'Concern for the judgement of history forces a recognition of the importance of the historical circumstances in which we find ourselves. While we do not know how those who look back on us from the future will judge us, or according to what values, we do know that they will not see us independently of our history. It remains true that we must make do with our own judgements. But we should do so in the knowledge that we will be judged alongside our history.' 
for our political association. Because our understanding of historical injustice depends on how we remember the past this seems to open the way for interminable dispute about the meaning of historical events. But, as Thompson (2002: 85-86) suggests, lack of agreement over what happened is not fatal for reconciliation so long as former enemies share a commitment to dialogue. Indeed, as we shall see, this interminable struggle to understand the significance of past wrongs for our present political association is the always-unfinished business of political reconciliation. 


\section{Remembrance}

If the act of constitution depends on recasting the present as a point of origin, it is through remembrance that this moment might come to be judged to mark the end of enmity. In chapter six, we saw that political reconciliation is initiated by constituting a space for politics, which makes possible an organised remembrance. Political reconciliation is impelled by an historical consciousness, the hope that our present actions will be judged by future generations as having established a new beginning. Such a reconciliatory politics is sustained, I argued in chapter seven, by the willingness to forgive. Political forgiveness is neither determined by necessity nor conditional on having just reasons to release our transgressors from the consequences of their actions. Rather, it is a free offer to the other to assume responsibility for past wrongs by entering into the play of the world. In chapter eight, I argued that political responsibility extends beyond accountability for those actions and intentions of which we are authors. Due to the boundlessness of action, we are politically implicated in injustice as both doers and sufferers. To assume responsibility for past wrongs therefore requires not merely that we settle accounts with those wronged but that we join with them in the risky venture of realising a world in common.

In this way, the aspiration to reconcile enables a politics in which citizens strive toward but never finally realise a shared understanding of the significance of past wrongs for their civic association. Consequently, as I will show in this chapter, just as the reconciled community is always not-yet so the task of remembrance remains always unfinished. In a divided polity, the politics of remembrance circles around uncovering the truth of past wrongs. Yet, as I discuss in 9.1, truth both frustrates and enables politics. While factual truth seems to foreclose politics by precluding debate, it nonetheless provides the stable ground on which the world-disclosing potential of politics depends. In 9.2, I show that the world-delimiting moment of 
remembrance depends on the redemptive power of narrative. Story-telling reconciles us to the irrevocable consequences of action by revealing our isolated doings and sufferings as part of a coherent whole. Yet, in the case of grave state wrongs, we are often confronted by happenings that resist narration and public witnessing. In 9.3, I show that the world-rupturing moment of remembrance depends on a monumental regard for the past. Rather than explaining events according to their place in the continuum of history, we should look to the past to testify to the possibilities of freedom in the present. In 9.4, I consider the implications of this account of remembrance for the work of truth commissions in commemorating a painful past.

\subsection{Truth and Politics}

Truth is often unwelcome in politics. This is so because, politically speaking, the truth is 'what we cannot change' (BFP: 264). Truth is frequently resented by political actors who, by definition, are concerned with changing the world. By contrast, there is an affinity between lying and politics since both depend on the human capacity to imagine the world as being different from what it is (CR: 6). Whereas the truth-teller seems to acquiesce in the way things are, the liar shares the actor's desire that the world be different from what it is (BPF: 251). Nevertheless, as Arendt insists, without individuals who are willing to testify to the truth - to say what is and cannot be otherwise - no permanence or continuity would be possible in human affairs (BPF: 229).

According to Arendt, the traditional conflict between truth and politics first emerged in the clash between philosopher and citizen. The trial and execution of Socrates demonstrated to Plato the risks of insisting on truth in the public realm. It was as a consequence of this experience that Plato came to define truth in opposition not to falsehood but opinion. The rational truth sought by the philosopher is necessary and, therefore, imperative (BPF: 230). In contrast to power, which rests on the opinions of the many, such truth is independent of agreement and consent. In this sense, it has a 'despotic character' (BPF: 241). Paradoxically, however, politics destroys the truth discovered by the philosopher in the solitude of thought by reducing it to one opinion among others when he submits it to the public 
realm. It was this realisation that led Plato to propose his utopia of a Republic in which the reign of truth would be strengthened rather than emasculated by power (see Arendt 1990). With the separation of church and state in modernity, however, it is the potential conflict between politics and factual truth, rather than the rational truth of the philosopher, that is of fundamental importance. While there is an unprecedented toleration of diverse philosophical and religious opinions, Arendt argues, 'factual truth, if it happens to oppose a given group's profit or pleasure, is greeted today with greater hostility than ever before' (BPF: 236).

Indeed, this was precisely what Arendt had encountered when she reported on the unwelcome facts of Jewish co-operation with the Nazis during her coverage of the trial of Adolf Eichmann - the Nazi official responsible for the transportation of Jews to the death camps. Arendt was deeply affected by the hostile response her 'report' elicited from many Jews, including some good friends. Since she felt compelled to answer her critics and defend the views she had expressed, the controversy took up a considerable amount of her time and energy in the immediate years following the trial (see Young-Bruehl 1982: 328-378). In her later reflections on truth and politics, Arendt writes that she wanted to clarify two issues that emerged from the controversy. First, is it always legitimate to tell the truth? Should the truth be known though the world might perish? Moreover, she wanted to account for the amazing number of lies that had been told throughout the controversy concerning both what she had written and the facts she had reported (BPF: 227).

From the beginning, Arendt recognized that the trial in Jerusalem was to be political since the Israeli prime-minister intended it to provide the world with a lesson in history. 'It is not an individual that is in the dock at this historic trial', Ben-Gurion had insisted, 'and not the Nazi regime alone, but anti-Semitism throughout history' (quoted in EJ: 19). The intent of the Israeli government, in staging the trial, was not only to bring one individual to justice but to 'reverse the past symbolically' by putting the persecuted victims in the place of the prosecutors (Bilsky 2001b: 243). As such, it was associated with consolidating the self-image of Zionist Israel, which was based on a certain 'never again': identification with the victims of the Holocaust accompanied by the determination to fight heroically for the 
survival of the community against the Arab enemy. To this end, as Leora Bilsky (2001b: 243) discusses, the 'line between victims and perpetrators had to be clearly demarcated' in the courtroom.

Consequently, the most controversial aspect of Arendt's report on the trial was her inclusion of a chapter on the cooperation of the Jewish Councils in organizing the transports (EJ: 112-134). Given the overtly political nature of the trial, Arendt was quick to notice the omission of the role of the councils from the public record the trial was supposed to establish (EJ: 124). The facts of collaboration were well known. They were 'discussed quite openly and with astonishing frankness in Israeli schoolbooks' (EJ: 119). Yet, the attorney general had appealed to the witnesses to 'abstain from an internal reckoning' for this was to be 'a trial of the murderer, not of the victims' (Hausner in Bilsky 2001b: 235). ${ }^{1}$ According to Gershom Scholem, the emphasis Arendt decided to place on the role of the Jewish councils in her report showed that she was without 'love of the Jewish people' (in JP: 241). ${ }^{2}$ Yet, Arendt justified her inclusion of this 'dark chapter' of history in her report because it offered 'the most striking insight into the totality of the moral collapse the Nazis caused in respectable European society...not only among the persecutors but also among the victims' (EJ: 125).

Following the Eichmann controversy, Arendt reflected that unwelcome factual truths tend to suffer a similar fate to rational truths in politics. Even though facts are less open to argument and more easily recognised than philosophical truths, they likewise tend 'not to be countered by lies and deliberate falsehoods but by opinion' (BPF: 237). The predicament of the reporter is just as perplexing as that of the philosopher when she sees her truth reduced to one opinion among others. But she is also worse off. For, whereas the ground of rational truth is transcendent and so continues to hold regardless of the opinions of the many, factual truth depends for its existence

\footnotetext{
${ }^{1}$ Bilsky (2001b) argues persuasively that this staged silence must be understood within the historical context of the trial and, particularly, in relation to the earlier libel case brought by Kastner in 1952, a Hungarian Jewish leader who had been publicly accused of collaboration with the Nazis (see Bilsky 2001a).

${ }^{2}$ In reply to Scholem, Arendt writes: 'Generally speaking, the role of the "heart" in politics seems to me altogether questionable. You know as well as I how often those who merely report certain unpleasant facts are accused of lack of soul, lack of heart or lack of what you call Herzenstakt. We both know, in other words, how often these emotions are used in order to conceal factual truth' (JP: 247).
} 
on being witnessed and testified to (LM 1: 59). Factual truths are political, then, in the sense that they refer and belong to the space of appearances (BPF: 238). Yet they share the despotic character of rational truths in their mode of asserting validity. An unwelcome opinion may be argued with or rejected but an unwelcome fact 'peremptorily claims to be acknowledged and precludes debate' (BPF: 241). Moreover, factual truths have a peculiar opaqueness by virtue of their contingency. Unlike opinions (or rational truths), they require 'no conclusive reason for being what they are' (BPF: 242). They are so only because things were not otherwise.

This 'stubborn thereness' of factual truth is the source both of its fragility and its resilience in the space of appearances (BPF: 257). Its fragility arises from the multitude of alternative historical possibilities that were never realised. Given the contingencies of history there is no limit to the range of convincing lies that can be told about the past. By contrast, those who testify to factual truth are at a peculiar disadvantage when confronted with lies. For, while facts often offend our common sense, lies tend to be more believable because the unexpectedness that characterises most real events is absent from them. Against an unwelcome truth that seems questionable, the liar has 'plausibility on his side' because he can mould the "facts" to suit the expectations and interests of his audience (BPF: 251; CR: 6).

But despite this frailty, factual truth is surprisingly resilient in politics (OR: 25). Modern political lies manipulate facts that are not secrets but are widely known. This is obvious in the case of totalitarian regimes that rewrite history 'under the eyes of those who witnessed it' (BPF: 252). But it is true also of the kind of image-making to which end Ben-Gurion wanted to put the Eichmann trial. ${ }^{3}$ Yet, although political power can destroy factual truth by denying it or reducing it to one opinion among many, it inevitably fails to provide an adequate alternative to it. Power can provide no substitute for the 'secure stability of factual reality' because it depends on the 'unreliable and only temporary agreement of many wills and intentions' (BPF: 258; HC: 201).

3 The Israeli government could not change the fact that millions of Jews submitted meekly to their death instead of resisting their persecutors heroically (EJ: 11). Forgetting the facts of collaboration, however, allowed the government to construct an ahistorical image of Israel as the pure and holy victim of timeless anti-Semitism, which provided it with enough "moral capital" to overshadow the particular injustices it was implicated in by present historical circumstances (EJ: 19; see also Bauman 2000: 256-240). 
Consequently, when the past is treated as an horizon of potentiality by political actors the long term effect is not that lies are accepted as truth but that a polity is pervaded by cynicism. This is so because, although politics is conditioned by the fact that the world appears differently to each of us, the possibility of politics also depends on our sense that we perceive the same object in common. Consequently, without the stability that factual truths provide to the transience of human affairs, we lose the 'sense by which we take our bearings in the world' (BPF: 257).

In politics a balance must be struck, then, between denying human freedom by treating facts as the necessary outcomes of historical processes and the hubris of overestimating the scope of this freedom by acting into the past (BPF: 259). Politics does not encompass all of human existence but is importantly limited by what we 'cannot change at will' (BPF: 263-264). It is only by respecting the limits of action that the integrity of both politics and truth are preserved. For if we treat the past and present as an open horizon of potentiality, politics is 'deprived not only of its main stabilizing force but of the starting point from which to change, to begin something new' (BPF: 258).

The stability afforded by acknowledgement of factual truth is therefore fundamental for sustaining a politics of remembrance among citizens divided by past wrongs. If deliberate falsehoods (such as the denial that concentration camps ever existed) are treated with the same respect as political opinions, the possibility of reconciliation is doomed from the beginning. Without a shared acknowledgement of the brute facts of state violence a polity lacks a common starting point from which to initiate political reconciliation. Yet, as Arendt observes, reality is more than the 'totality of facts and events, which, anyhow, is unascertainable' (BPF: 261). Reporting factual truth always also involves interpretation and judgement since facts must be selected according to some criteria of significance and ordered on the basis of particular conventions in order to be publicly communicable. As such, remembrance always entails naming and narration (BPF: 5f.). 


\subsection{The redemptive power of narrative}

As that activity by which we strive to make our knowledge of facts meaningful, remembrance is 'helpless outside a pre-established framework of reference' (BPF: 6). While our understanding of the past depends on knowledge of the facts, we cannot know the facts in the first place without a 'preliminary, inarticulate understanding' (EU: 310). This pre-understanding, which conditions the way we approach the past, is contingent on our present situation and the categories and frameworks we inherit from tradition. The questions we ask of the past, the events that appear significant to us and the relations we perceive between them arise from our concerns and interests in action, our preoccupation with the world both as it is and as it will be.

Consequently, as Maurice Halbwachs (1992: 40) argues, the past is 'not preserved but is reconstructed on the basis of the present'. Our account of past events changes over time because the way history unfolds itself affects our understanding of the past (McClure 1998: 234; Sparrow 2000: 347). Recent events reveal the past in a new light, so that we discern beginnings that were previously unnoticed. Actions and events that once seemed of little consequence now become significant (EU: 319). Moreover, the past is recalled, re-described and re-organised in terms of the narratives and categories of understanding that our present culture makes available to us (see Prager 1998: 134f.). It is due to this dependence of the past on the present that history is always political. ${ }^{4}$ Yet, although the past is constantly being retold in order to legitimate present projects, it also often resists being reconstructed according to the demands of politics. Halbwachs (1992: 40) only states half the truth when he argues that we 'reconstruct an image of the past that is in accord, in each epoch, with the predominant thoughts of the society.' For, if it is true that our present situation shapes our understanding of the past, it is equally true that our past has shaped our present situation.

\footnotetext{
${ }^{4}$ However, as Arendt insists: 'Even if we admit that every generation has the right to write its own history, we admit no more than that it has the right to rearrange the facts in accordance with its own perspective; we don't admit the right to touch the factual matter itself' (BPF: 238-239).
} 
Our understanding of the past is not only the product of the present, then, but rather arises from a dialogic relation between the present and its past. ${ }^{5}$

Central to the task of acknowledging the past is our ability to name. By naming we individuate events (identify a range of actions as converging to form one significant historical outcome such as 'the Holocaust') and recognise sameness and difference (relate this event to others) (EU: 312 ). The possibility of remembrance depends on this 'thinking completion' of the enacted event through naming (BPF: 6). We always begin by construing recent events in light of old, naming the world according to the language inherited from those who came before us. However, it is only by transcending our familiar categories of understanding that we approach our object of inquiry more closely. True understanding requires that we return to the 'judgements and prejudices which preceded and guided' our initial encounter with the past in order to call them into question, to discover whether they properly articulate and make sense of this new experience (EU: 311). This new understanding we arrive at forms the basis for further inquiry. It is due to this virtuous hermeneutical circle that understanding is 'unending' and does not produce 'final results' (EU: 308, 322). ${ }^{6}$

But in remembering we not only name but narrate the past. For Arendt, the semantic richness of narrative inheres in its capacity to 'reveal meaning' without 'defining it' (MDT: 105).7 A story is intended to elicit understanding rather than to explain events and, in this way, differs fundamentally from what Walter Benjamin (1992: 88-89) calls 'information'. When communicated as information, an event comes to us 'shot through with explanation' so that it appears 'understandable in itself' (Benjamin 1992: 89). By contrast, the strength of a story depends on the absence of

\footnotetext{
${ }^{5}$ Our freedom to remake the past is limited by what Schudson (1989: 107) identifies as 'the structure of available pasts, the structure of individual choices and conflicts about the past among a multitude of mutually aware individuals and groups'.
}

${ }^{6}$ As Gadamer (1986: 272) writes: 'We are always affected, in hope and fear, by what is nearest to us, and hence approach, under its influence, the testimony of the past. Hence it is constantly necessary to inhibit the overhasty assimilation of the past to our own expectations of meaning. Only then will we be able to listen to the past in a way that makes its own meaning heard'.

${ }^{7}$ As Hutchings (1996: 88-89) points out, 'the storyteller does not exercise sovereignty but interprets without recourse to any rule or law, so that storytelling is like action in being neither legislative nor legislated'. 
explanation. The events unfolded in the narrative are left to "speak for themselves". This distinction between the explanatory nature of information and the understanding sought through narrative becomes apparent, for instance, in the inevitable failure of attempts to deal with past wrongs by explaining 'objectively' what happened. For, in the absence of an effective narrative, a surfeit of information leads us to become 'submerged in a chaos of details' and, thus, 'unable to understand or make clear the nature of the facts' with which we are confronted (EU: 197-198). ${ }^{8}$

'The political function of the story-teller' writes Arendt, 'is to teach acceptance of things as they are' (BPF: 262). We cannot change the unwelcome facts of our history but we can reconcile ourselves to 'what irrevocably happened and...what unavoidably exists' (EU: 322). By virtue of being incorporated into a story with beginning and end, facts lose the opaqueness associated with their contingency and acquire a 'humanly comprehensible meaning' (BPF: 261). Through its narration the past is revealed as a 'network of related events' (Honohan 1990: 315). By narrating past events, what would otherwise appear to us as 'an unbearable sequence of sheer happenings' becomes meaningful (MDT: 104). The apparent absurdity of our acting and suffering in the world is transformed into a tragic sense of how things came to pass (HC: 235 - n. 75). Our isolated doings and sufferings are drawn together into a significant whole. Or, as Ricoeur (1981: 174) puts it, the act of the plot elicits a pattern from succession.

The 'redemptive power of narrative' arises from this making whole of our otherwise fragmentary experience (see Benhabib 1994: 120f.). Narration initiates a process of understanding through which we orient our selves to 'a world changed through a new event' (EU: 325). With the re-collection of experience within a public space, the story becomes a 'thing outside' the subject who acted and suffered it, 'an "object" for all to see and hear' (BPF: 45). Human experience is 'transformed' by public narration, 'deprivatised and deindividualised' so that its significance for our life in common can be grasped (HC: 50 ). The reconciliation with reality that is elicited by story-

\footnotetext{
${ }^{8}$ As Buckler (2001: 292) writes, 'Neither forensic evidence nor personal testimony is, in itself, an articulation of a historical event. Collations of evidence do not in themselves answer the question: evidence for what? And personal testimonies in themselves beg the question: to what do they testify? Some version of events is [required] to which evidence and testimony may stand as contributions.'
} 
telling may be experienced as a catharsis in which the shock of experience is publicly felt and come to terms with (see Herzog 2000: 17-18). Catharsis overcomes the political actor's resentment of what cannot be changed, which Nietzsche calls 'the will's ill will against time and its 'it was" (in Beiner 1982: 149). By reconciling us to the 'changed set of circumstances the event has created', it clears the way for action, which treats this end as an opportunity to begin something new (EU: 319; BPF: 262).

Isak Dinesen's words that 'all sorrows can be borne if you put them into a story or tell a story about them', which are frequently cited by Arendt in this context, have become something of a platitude among advocates of truth commissions (HC: 175; MDT: 104; BPF: 262). They suggest that the possibility of mastering a painful past depends on public recollection and witnessing of the stories of survivors. ${ }^{9}$ For, as Arendt puts it, the meaning of an act 'is revealed only when the action itself has come to an end and become a story susceptible to narration' (MDT: 21 - emphasis added). Yet as Judith Herman (1992: 1) observes, 'certain violations of the social compact are too terrible to utter aloud'. Indeed, such 'unspeakable truths' tend to resist narration and, hence, remembrance (see Humphrey 2000: 10-13; Hayner 2002: 133-153).

As Steve Buckler (2001: 288-290) discusses, despite the tremendous documentation of facts and accumulation of testimony, the Holocaust remains susceptible to denial and emasculation. This fragility arises in part due to the fact that the truth is often unwelcome in politics because it offends against common sense, as already discussed. Yet, it is further complicated by the difficulty survivors have in testifying to the reality of the experience by naming and narrating the past. Survivors of the death camps are often frustrated in their attempts to find coherent narratives in terms of which to organise the facts of their experience. 'Far from being redemptive', such anguished memory, 'collapses into uncertainty' (Buckler 2001: 288). This is due to the anxiety, on the part of the survivor, that the story you tell 'drives off the audience you want to capture' and the 'further suspicion that the

\footnotetext{
${ }^{9}$ For instance Terry Dowdall (1996: 34) writes, in relation to South Africa, that a truth commission 'can contribute to rehabilitation by breaking the culture of silence. We all know that concealing, suppressing or repressing painful memories commonly brings in its wake psychological symptoms: stress, anxiety, and depression. We also know that speaking about upsetting things in a supportive and affirming setting makes people feel better.'
} 
story you tell cannot be precisely the story as it happened' (Langer in Buckler 2001: 288). Survivors' accounts lack plausibility because they fail to satisfy social expectations not only of what is believable but of what makes a coherent narrative, a story that is worth telling. Or else, to the extent that they do satisfy these expectations, they fail to adequately communicate the experience. ${ }^{10}$

This fragility extends beyond the personal memory of those traumatised by political violence to affect the collective memory also. For, in relation to the Holocaust, the 'external confirmation and memorialisation which might ameliorate the worst effects of personal trauma have failed to materialise' (Buckler 2001: 289). No adequate public history of the Holocaust has emerged into which the personal stories of the victims might be fitted. As Buckler (2001: 292) points out, for a narrative to be intelligible it must represent 'recognisable human disclosures'; that is, the 'motives, intentions, actions and responses that make up the narrative' must be able to establish a 'compelling and coherent sense of its dynamics' for the audience. Despite our knowledge of a bare set of occurrences (ghettos, deportation, concentration, annihilation) the reason that no consolidating narrative has emerged around the Holocaust seems to be related to the world-curtailing nature of the crime (see 4.1). The dehumanisation of the victims renders problematic the possibility of a cathartic remembrance. ${ }^{11}$

\footnotetext{
${ }^{10}$ As van Roermund (2002) writes: 'For the surviving victims, the suffering in the past is often one of absolute singularity. The mere demand that the past should be 'worth telling' (if only to prevent it from happening again in the future) entails that there be some general idea of suffering: its forms, its means, its sense, its cause. This contradicts the singular experience of survivors, who then may decide that there is 'no point' in telling their story.' What is more, 'survivors find themselves unworthy as narrators. For apart from the past having to be 'worth telling', it has to be told by someone who is entitled to tell it. The entitlement has to come from his or her community. But survivors often feel ashamed of their being alive, like traitors of the victims who died during oppression. They feel alone and without a community. They may also feel ignored or betrayed by the community they are surviving in.'

${ }^{11}$ If the achievement of narrative is, as Ricoeur (1981: 172) suggests, that it makes the succession of experience meaningful by ordering events according to the time of the world (i.e. 'time woven in common' by human inter-action) then the difficulty of reconciling ourselves to the reality of the Holocaust has something to do with our sense, due to the failure of narrative, of the event having occurring outside time. As Buckler (2001: 293) writes: 'In respect of the Holocaust and the story of the victims, where the experiences at issue are the experiences of persons turned effectively into "non-persons" and where identities are not disclosed in the usual way, meaning may prove illusive. And although we can know and recognise as persons those who survived to recount the experience, we find difficulty in
} 
A redemptive remembrance requires not just the narration of actions and events but their public articulation and witnessing, which establishes enough distance between the agent and what he has done and suffered for him to be reconciled to what has irrevocably happened. The public communicative setting provides a cognitive guarantee that saves the past from oblivion. Yet such witnessing does not appear to be available in the case of the Holocaust, which is in danger not so much of being forgotten but of not being adequately remembered. For events surrounding it resist objectification, the shift from personal to public memory, from the first person to third person perspective, which makes it safe to let go. Buckler (2001: 295-296) argues that signs of a 'communicative malformation' abound in the Holocaust debate, which compromise our ability to collectively "witness" the Holocaust. ${ }^{12}$

Many of the difficulties surrounding attempts to commemorate the Holocaust appear to recur in other contexts where people have been traumatised by widespread state violence. ${ }^{13}$ As Michael Humphrey (2000: 7) observes, political violence does not only terrorise by inflicting physical injury but also traumatises by 'inscribing the memory of violence in the bodies of the victims.' When widespread, such painful personal memories can have disastrous consequences for human society. Trauma, as we saw in 1.4 , expresses itself as time standing still, the continual re-enactment of the past in the present. Thus, Michael Ignatieff (1996: 120-121) suggests, in polities divided by grave state wrongs people often do not live in a 'serial order of time' but a 'simultaneous one, in which the past and present are a continuous, agglutinated mass of fantasies, distortions, myths and lies.' Journalists reporting on the Balkan wars, for instance, were sometimes

knowing them as participants in that unimaginable setting; just as, in the same way, they cannot readily identify themselves as such.'

12 These include 'the non-availability of plausible generalisation, the misfiring of analogies, indeterminacy of authorial intentions, the curtailment of reflexive certainty' (Buckler 2001: 296-297).

${ }^{13}$ For instance, Claire Moon (2002) argues that, in general, torture 'cannot be assigned retrospectively a place within a unified narrative, that is, a newly made world, not only because its narration elides the victim's experience but also because it breaks with the teleological function of narrative: its inexplicability and inexpressibility resist narrative formulation...Torture represents an assault on narrative itself if narrative is constitutive of causality, knowledge and teleology.' 
unsure whether atrocities recounted to them had occurred 'yesterday or in 1941 or 1841 or $1441^{\prime}$ (Ignatieff 1996: 121).

Since experience only makes sense to the extent that it is spoken about, the potential incommunicability of the memory of violence presents a grave challenge for political reconciliation. For it suggests that the failure to integrate the memory of offence into a coherent narrative and, thus, to reconcile ourselves to the changed reality it has brought about, prevents us from acting anew in the present. Yet political reconciliation is threatened not only by the failure of memory in the absence of a redeeming narrative but also by the prospect of a surfeit of a memory that seems to unduly limit the possibilities of the present. As such, political reconciliation seems to require not only the making whole of fragmented experience but salvaging from the past such forgotten fragments that point to the possibilities of action in the present.

\subsection{The judgement of history}

Confronted by the failure of a redemptive narrative we might wonder whether it is better to forget the past than remain in its grip. Nietzsche (1983: $62,67)$, for one, argues that 'forgetting is essential to action of any kind' and that an 'excess of history is harmful to the living man'. And yet, as Adorno (1986: 125) warns, the danger of forgetfulness is that it 'too easily goes along with and justifies what is forgotten'. But Nietzsche does not advocate historical oblivion. While all happiness depends on forgetting, a life without memory would be a life without depth. Rather, he insists, we must employ history for the purpose of "life". Every individual and every political community requires, 'in accordance with its goals, energies and needs, a certain kind of knowledge of the past' (Nietzsche 1983: 77). What we do not need, however, is history "for its own sake." For the past then threatens to overwhelm us. History is in the service of life only to the extent that we judge it rather than judging ourselves according to it. History serves life when we wrest the significance of events from the past. But history diminishes us when we seek to explain the significance of events and actions according to their place in within its sequence (Nietzsche 1983: 105-106). 
Following Nietzsche, Arendt rejects the aspiration to a science of history, according to which the meaning of events could be derived from their function in an historical process. This turn to history for meaning offends against human dignity because it reduces the significance of the particular to its place in the whole, the meaning of an individual's life to its contribution to an ultimate end he will never comprehend or enjoy (BPF: 56f.; LKPP: 56-58). Moreover, far from avoiding prejudice, leaving history to be the judge of human affairs means that the implicit criterion of significance is success (see Honohan 1990: 320). If it is the tendency of the actor to overestimate the extent of human freedom by denying factual truth, then, it is in the nature of the professional historian to deny this freedom by discovering the causes of human action in preceding events (BPF: 250-251). Yet, the seeming inevitability to a chain of historical events is an illusion that appears only in retrospect, when action loses its aspect of contingency and becomes part of the unchanging factual reality of the world.

With his metaphor of the angel of history, Walter Benjamin (1992: 249) presents an alternative philosophy of history to that which Arendt rejects. Instead of waiting at the end of time to deliver its final judgement, the angel of history is blasted backwards into the future. ${ }^{14}$ For Benjamin, there is an urgency to historical reflection because the past is irretrievable if we miss the present moment in which it is revealed to us (see Beiner 1984: 247). Whereas the historicist sees an inert chain of events, Benjamin sees a ruined past in need of salvation. It is complacent to view history as a continuum of progress. For every success on which this progress is built consigns to oblivion the failed hopes and deeds of the defeated. Against the complacency of the historicist, he insists, we must 'brush history against the grain' (Benjamin 1992: 248). We must attend to moments of rupture and discontinuity in history in order to redeem the memory of the vanquished

\footnotetext{
14 'His eyes are staring, his mouth is open, his wings are spread... His face is turned toward the past. Where we perceive a chain of events, he sees one single catastrophe which keeps piling wreckage upon wreckage and hurls it at his feet. The angel would like to stay, awaken the dead, and make whole what has been smashed. But a storm is blowing from Paradise; it has got caught in his wings with such violence that the angel can no longer close them. This storm irresistibly propels him into the future to which his back is turned, while the pile of debris before him grows skyward. This storm is what we call progress' (Benjamin 1992: 249).
} 
since 'even the dead will not be safe from the enemy if he wins' (Benjamin 1992: 247). 15

Arendt similarly wants to deny History's right to be the 'ultimate judge' in human affairs (LM I: 216; BPF: 51). ${ }^{16}$ Against the modern conception of history, which reduces the meaning of action to its place in an historical process, Arendt insists that the meaning of action must exceed that which can be derived from a temporal order (see Beiner 1982: 145). Human dignity rests on our 'possible independence of things as they are or as they have come into being' (LM I: 216). In order to dignify human affairs we must be able to judge the moment as meaningful in itself. The significance of action must be 'independent of victory or defeat' because time will only "tell" the story of the victors (HC: 205). In judging the past, therefore, we must attend to its unfulfilled revolutionary moments, to failed beginnings as well as successes.

Yet Arendt wants not only to do justice to the memory of the defeated but, like Nietzsche, to find a way of 'preserving the past without being enslaved by it' (Benhabib 1994: 120-121). Whereas Benjamin sees in the present the possibility of redemption for the defeated in history, Arendt looks to the past for exemplars that attest to the 'positive possibilities of human existence' in the present (Honohan 1990: 313). In doing so, she adopts what Nietzsche (1983: 67f.) calls a monumental regard for the past. Such historical judgement, as Judith Shklar (1998: 359) observes, is 'selective, dwelling only on those moments that have a constructive present bearing, and it emphasizes the avoidable in contrast to the inevitable'. Attention to the deeds and aspirations of the defeated is important because it points to a 'counter-world' in the present, to how things might otherwise be (Nietzsche 1983: 68). The criteria of significance, then, is not success but greatness. We look to those extraordinary events and actions that might illuminate everyday occurrences by testifying to human freedom (HC: 79, 205-207; BPF:

\footnotetext{
${ }^{15}$ As Annabel Herzog (2000: 16) writes, such an attitude to the past reveals the deeds and aspirations of the defeated 'as absence in collective memory. It deciphers the traces of history as if they were symbols, symptoms of the holes of history - holes of memory; it shows these as holes.'

${ }^{16}$ Several commentators have observed Benjamin's influence on Arendt. See especially Beiner (1982: 155-156; 1984: 433, n. 12); Benhabib (1994: 124-131), Herzog (2000); Honohan (1990: 313-322) and d'Entrèves (1994: 31).
} 
153; LM I: 131). Arendt recognises that the periods in which human freedom has been realised 'have always been relatively short in the history of mankind' (BPF: 169; OR: 265-267). Yet the greatness of such historical moments does not depend upon their influence in human affairs but their affirmation of the possibilities of action in the present (see Honohan 1990: 316).

The significance of this monumental regard to the past for reckoning with grave wrongdoing is revealed by Arendt's remarks about Anton Schmidt, a German sergeant who assisted the Jewish underground in Poland by supplying forged papers and military trucks without seeking personal gain. This went on for five months before he was arrested and executed in March 1942. With the mention of Schmidt's name during the course of the Eichmann trial, Arendt reports, 'a hush settled over the courtroom'. In this moment a single thought seemed to hang in the air: 'how utterly different everything would be...if only more such stories could have been told' (EJ: 231).

To explain why there are so few similar stories to be told, Arendt turns to the memoirs of Peter Bamm. He accounts for his own lack of heroism by protesting that while such sacrifice would not have been morally meaningless it would have been practically useless because one would have died an anonymous death at the hands of the regime. In response, Arendt insists that such exemplary action is never useless but stands as a monument to human dignity. There are 'too many people in the world' for totalitarian regimes to succeed in consigning the deeds of their opponents to oblivion since 'one man will always be left alive to tell the story' (EJ: 233). Moreover, there is an urgent need, in the wake of grave state wrongs, for stories like that of Schmidt. For they demonstrate that although many people will support a murderous regime under conditions of terror some will not. And acknowledgement of this truth, Arendt concludes, is sufficient for the world to remain a 'fit place for habitation' (EJ: 233). In revealing that there was no inevitability to the wrongs that were perpetrated, such stories shows a way to resist the legacy of grave state wrongs.

Yet how might such a monumental regard for the past guide remembrance of acts that, far from disclosing the ethical possibilities of the 
present, remind us of the potential for world-curtailing violence? According to Arendt, 'all historiography is necessary salvation and frequently justification' (EU: 402). But, in the case of an unprecedented negative event such as the Holocaust, then, we are confronted with the predicament of recalling something we do not want to preserve but feel compelled to destroy. Arendt observes that the achievement of memory is that in presenting the past and then depriving it, in a sense, of its bygone quality, [it] transforms the past into a future possibility' (LSA: 48). We have seen why this prompts us to recall those events that attest to the potential for freedom in the present. In the case of recalling negative events, however, the fearful anticipation of the event recurring undermines the conditions of trust that might sustain a reconciliatory politics. ${ }^{17}$

As Buckler (2001: 296) observes, the significance of foundational acts 'lies in their articulation of the power of beginning and their tendency to leave a communicative legacy in the form of "an entirely new story, a story never known before"' (OR: 28). Such events are enabling since they inspire and provide a context for future action. The source of their communicative power arises from the world-disclosing potential of collective action and the establishment of limits in relation to which actions may be judged. By contrast, the event of the death camps threatens to explode 'all conditions of trust and agreement...through the fullest enactment of the notion that "everything is possible"' (Buckler 2001: 298). As unspeakable memory that resists narration, this unprecedented negative event is potentially selfreproducing. The 'corrosive suspicion that everything is possible, that the possible may outrun the "speakable,"...threatens to erode communicative confidence and to collapse the space in which freedom is enacted' (Buckler 2001: 299). That is, the collective memory of grave wrongdoing, on which the possibility of community is frequently assumed to rest, threatens to undermine the conditions in which an organised remembrance is possible in the first place.

\footnotetext{
${ }^{17}$ For instance, Zygmunt Bauman (2000: 233) observes that 'Among the Jews...living in a world contaminated by the possibility of a Holocaust rebounds time and again in fear and horror. To many the world appears suspect to the core; no worldly event is truly neutral each event is burdened with sinister undertones, each contains an ominous message aimed especially at the Jews, a message that can be overlooked or played down only at the Jews' own peril'.
} 
In such circumstances, a monumental regard for history suggests that remembrance should be animated by the awareness of a predicament: the potentially self-reproducing negative legacy of grave wrongdoing. The acknowledgment that something has happened that should never have been allowed to occur establishes the urgency of politics in the present. If a monumental regard for history celebrates moments of greatness in the past that testify to the possibilities of freedom in the present, in attending to moments of violence it reminds us that we must invoke politics to resist the inevitability of a world created by past wrongs. As such, a monumental regard for history requires, as Aletta Norval (1998: 259) suggests 'remembrance of the logic of closure' and its disastrous effects for human society. Remembrance of grave wrongs is often urged on the grounds that those who forget the past are likely to repeat it (Hayner 2002: 30). Further to this, a monumental regard for history suggests that, against the desire to reify the past in order to cordon it off from the present, the past must be constantly revisited and renegotiated, its continuity with the present acknowledged in order that its negative legacy - the corrosive suspicion that what has been could be again - might be resisted. ${ }^{18}$ As such, remembrance always involves "unfinished business."

\subsection{Commemoration}

Kader Asmal and others (1996: 46) have argued that the "memory-work" of political reconciliation involves 'the facing of unwelcome truths in order to harmonise incommensurable world views so that inevitable and continuing conflicts and differences stand at least within a single universe of comprehensibility.' There is, in this, both an acknowledgement of the politics of remembrance and an elision of its risks. For, although there is recognition of the inevitability of continuing conflicts and differences, there is an

\footnotetext{
18 Such an attitude to the past is evidenced, for instance, in the 'counter'-monument against fascism in Hamburg: a 12 metre high obelisk that is gradually sinking into the ground, on which people are invited to mark their names. Inscribed on it are the words: 'One day it will have disappeared completely and the site of the Hamburg monument against fascism will be empty. In the end, it is only we ourselves who can rise up against injustice' (in Norval 1998: 260).
} 
unwarranted presumption that incommensurable world views can and will be brought into a single universe of comprehensibility.

As we have already seen, if reconciliation is to be political it must be predicated on an awareness not only of the inevitability of conflict but that the conflict of the past might not turn out to be communal (see $3.3 ; 6.4$ ). While the invocation of a community that is not-yet constitutes a shared horizon in terms of which past conflict might be collectively understood, there is no inevitability to this. Remembrance of past wrongs must be conditioned by an awareness of this risk because the presumption of a common past undercuts reconciliation in the present. Against such presumption, political reconciliation depends upon an awareness that every act of remembrance also entails forgetting, that beyond the narratives by which we make sense of experience lies a surfeit of memory that remains unrepresented and, perhaps, unrepresentable, and, therefore, that past wrongs can never be adequately acknowledged. Consequently, a joint remembrance (or co-memoration) of past wrongs must involve not only the effort to establish a common memory by virtue of a redemptive narrative that reveals our isolated doings and suffering as part of coherent whole. It must also entail a monumental regard for the past, which checks the impulse to leave the past behind by calling attention to new aspects of old injustices in the light of contemporary conflicts. If the desire for redemption is not to lead to the appropriation of the suffering of others for the sake of a national catharsis, this desire must be tempered by a sense of the unacknowledgeability of the past.

As Bert van Roermund (2001: 177) observes, political reconciliation 'both requires and forestalls the revelation of truth.' Without acknowledgement of the brute facts of state violence, former enemies lack a common reference point in terms of which to engage in a reconciliatory politics. And yet, given the fragility of factual truth, the difficulties of testifying to and witnessing grave wrongs and the erosion of trust and human solidarity insinuated by the memory of offence, we can see why political reconciliation cannot be conditional on first establishing a shared account of past wrongs. 
Truth commissions can play an important role in commemorating the past, both in establishing a public record of the elementary facts of wrongdoing and providing a context within which former enemies can contest the significance of past wrongs for their political association. ${ }^{19}$ Given the denial of wrongdoing by the former regime, official acknowledgement by the successor regime is a fundamental achievement of a truth commission. Often enough, the facts are widely known. However, putting them on public record makes them more difficult to deny and thus helps to establish the common ground on which political reconciliation must be predicated. Yet, as Primo Levi (1986: 132) points out, descriptions of the facts of wrongdoing tend to be of minor interest since they now belong to history. 'Much more important and interesting are the motivations and the justifications: Why did you do it? Were you aware of committing the crime?' In this context, the importance of a truth commission for reconciliation is not primarily that it establishes a final, authoritative record of past wrongs, which might provide the basis for a settling of accounts. Rather, it can help to establish those communicative conditions that were negated by wrongdoing (and which continue to be undermined by the memory of offence) by calling former enemies to account for the past.

Amy Gutmann and Dennis Thompson (2000: 35-38) argue that a fundamental goal of truth commissions should be to contribute to the establishment of a 'democratic reciprocity' in the culture of a divided society. ${ }^{20}$ Through its work, a truth commission ought to 'exemplify how people can live with continuing disagreements about what exactly happened in the past and why, and still respect each other as fellow citizens.' For the

\footnotetext{
${ }^{19}$ While the structure and terms of reference of various truth commissions have varied considerably from case to case, Priscilla Hayner (2002: 24-31) identifies five basic aims that are common to many of them: to clarify and acknowledge the truth; to respond to the victims; to contribute to justice and accountability; to outline institutional responsibility and recommend reforms; and to promote reconciliation. Political trials, such as that of Eichmann, may serve a similar role in providing a site for collective memory (see Osiel 1997). However, whereas a trial must ultimately concern the criminal culpability of a particular individual, truth commissions allow for a fuller accounting of past wrongs in relation to the political context in which they were perpetrated.

${ }^{20}$ Drawing on their work in deliberative democracy, Gutmann \& Thompson (2000:36) explain that reciprocity 'asks citizens to try to justify their political views to one another, and to treat with respect those who make good-faith efforts to engage in this mutual enterprise even when they cannot resolve their disagreements. Reciprocity also calls for establishing social and economic conditions that enable adults to engage with each other as civic equals.'
} 
efforts of citizens to provide an interpretation of their political past that others might agree with or call into question indicates the willingness of citizens to acknowledge each other as co-builders of a common world. For all its failings, there were moments during the course of the Truth and Reconciliation Commission in South Africa when such a reckoning was dramatically enacted. For instance, Christodoulidis (2000: 179f.) discusses the opportunity the TRC provided for Tony Yenengi to ask his torturer, Jeffrey Benzien, "what kind of man could do this to another?" Torture, as Christodoulidis points out, is not just a violation but a negation of the ethical, according to which his position as interlocutor, as speaking subject, is denied. By contrast, communication 'invokes ethics back.' In the forum of the TRC, Yenengi 'becomes someone to whom an explanation is owed... what is undergone, ever so tentatively, is the experience of community as communication.'

Yet truth commissions sometimes also attempt to do more than this. In collating personal memories of the past they hope to establish a redemptive narrative, a collective memory that might provide the basis for a new civic identity that could encompass both victims and perpetrators. Identity, as John Gillis (1994: 3) observes, is sustained by memory just as 'what is remembered is defined by the assumed identity.' 21 The constitution of a space of appearances establishes the possibility of a shared understanding of the past by establishing a subject in terms of which a plurality of memories can be organised. As we saw in chapter six, it is in the context of revolution, when actors seek to enact a break with the past, that the need to commemorate the past becomes most urgent. ${ }^{22}$ Modern commemorative practices emerged from an awareness of the contested nature of the past and its importance for legitimating present projects (Gillis 1994: 8-9). The fact that the new republics of France and America were so fragile seemed only to intensify commemorative efforts after the revolutions. 'If the conflicts of the

\footnotetext{
21 Since identity refers to a sense of sameness over time and space, every identity has a history. But similarly, no history cannot be told in the absence of a subject that persists through time (Sparrow 2000: 348).

22 A traditionalist society that understands itself to have been unchanging, to have followed the same traditions since time immemorial, has no need for commemoration. For the dead and the living are felt to 'inhabit the same space and time' (Gillis 1994: 11). By contrast, it is a sense of social change and thus a concern that this community be sustained, this beginning preserved, that drives us to commemorate the past.
} 
present seemed intractable, the past offered a screen on which desires for unity and continuity, that is, identity, could be projected' (Gillis 1994: 9).

Members of two different groups might participate in the same historical event, such as "the Troubles" in Northern Ireland. Yet, as Paul Connerton (1989: 7) suggests, it is conceivable that their understanding of this event may be incommensurable so that 'their subsequent memories of that event, the memories they pass on to their children, can scarcely be said to refer to the 'same' event.' Yet this is a possibility that the restorative conception of reconciliation cannot acknowledge. Underpinned by the sense that an identity is sustained by remembrance, restorative reconciliation presupposes that the conflict of the past was communal. In doing so, it seems to require a 'collective memory that could never have been and yet seemingly must be' (Veitch 1999: 157). The assumption underwriting the recollection of past wrongs is that without a common memory there is no community, that unity may be measured by the extent to which a common memory subsists (Niebuhr quoted in Veitch 1999: 154). In this context, it is not just the fragmentary experience of survivors that truth commissions seek to make whole but that of the polity. As James Booth (2001: 787) suggests, memory-truth, in such instances, is concerned less with establishing what took place than with restoring unity to a shattered community. Consequently, the 'truth at issue is the truth of that unity or identity, secured through remembrance.'

Healing the lives of individuals traumatised by state violence in this way becomes a metaphor for 'healing' the body politic (see Trumper 1999). As Michael Humphrey (2000: 9f.) discusses, truth commissions invert the politics of pain of the former regime by shifting the focus from terror to trauma. They recover meaning by 'addressing the pain inflicted rather than by inflicting the pain.' The purpose of listening to the stories of violence told by victims is to 'make private pain public' and to identify the 'political origins of that pain' (Humphrey 2000: 14). Following the restorative account of reconciliation, the revelation of the origins of violence evokes the basis of its prohibition and so restates the moral relations upon which community is predicated. The assumption of community recalls the conflict of the past as 
communal in order to establish the possibility of reconciliation. ${ }^{23}$ Through commemoration, past wrongs are re-presented, as we saw in 1.4, in terms of an account that must be settled, a wound that must be healed, an alienation that must be overcome.

In her influential book, Trauma and Recovery, Judith Herman (1992: 1) insists that, 'remembering and telling the truth about terrible events are prerequisites both for the restoration of the social order and for the healing of individual victims'. Yet, as Jeffrey Prager (2001b) discusses, psychologists such as Herman tend to neglect the extent to which the meaning of past events is contingent on the present cultural narratives into which we fit them. Rather than attending to 'what narratives of the past reveal about meanings and perceptions in the present' they tend to isolate narrative from its production. The story that the therapist or truth commission elicits from the victim thereby tends to be treated as 'external to the narrator and as revelatory of the historical origins of the narrator's current pain' (Prager 1998: 136). By isolating narrative from its social production, in this way, the therapeutic metaphor tends to depoliticise the terms within which the past is recovered.

A "therapeutic" politics of remembrance thus tends to forget what must be excluded in order to "redeem" the suffering of the victims in accord with the unifying narrative it seeks to establish. Indeed, reconciliation itself provides a meta-narrative according to which the violent events of the past are selected, ordered and made meaningful. As Claire Moon (2002) explains, in Chile and South Africa, reconciliation provided a governing narrative according to which individual testimonies were organised into a new moral and political framework. ${ }^{24}$ However, rather than capturing the singularity of survivors' experience, the narrative of reconciliation appropriates it for the sake of the nation. In the case of the TRC, for instance, Michael Humphrey

\footnotetext{
23 'The TRC, the forum of collected memories, becomes the institution that marshals collective memory; the assumption that collected can become collective usurps and overdetermines; it is an a priori assumption that when read into reconciliation cancels it out by doing violence to the understandings that might have established it' (Christodoulidis 2001a: 222).

24 'As a disciplinary narrative, reconciliation permitted the rewriting of the past and the emergence of a concomitant moral vocabulary with which to tell a story that was coherent with contemporaneous political propensities' (Moon 2002).
} 
(2000: 18) argues that 'all injury, death and suffering was homogenised' in terms of 'an heroic nationalist narrative' according to which these were understood to have been for the sake of 'a better society'. Far from bringing about personal healing this 'co-optation and translation of individual victim stories into heroic narratives often left individuals feeling that they had reproduced themselves as victims' (see also Veitch 1999). As we saw in 9.3, rather than restoring the dignity of the victims, this kind of remembrance offends against human dignity by explaining suffering in relation to an ultimate end of history. ${ }^{25}$

Against this tendency to redeem the past in terms of a teleological order, we must invoke politics. For, when a restorative conception of reconciliation comes to serve as a meta-narrative, a template of meaning against which the significance of the past is measured, it provides too easy an escape from the interpretative agonistic struggle by which the significance of the particular might be disclosed. Instead the particular is subsumed under the general, rendered familiar according to common sense. The commemorative practice of reconciliation is in this way reduced to 'a sharing that trivialises: from stark singularity to banal familiarity' (Christodoulidis 2001a: 223). A monumental regard for the past that seeks to preserve the memory of injustice is frustrated by such domestication which forgets the other it seeks to make present. Moreover, when undertaken in these terms, commemoration 'requires the forgetting of that which may question the community and its legitimacy' (Lyotard in Christodoulidis 2001a: 222). ${ }^{26}$ For instance, David Blight (2001) discusses how the desire for reconciliation between North and South in the wake of civil war in the United States led to the production of a collective memory that omitted questions of race and slavery as central to the conflict. It is against such exclusions, on which a redemptive memory is invariably predicated, that a monumental regard for history must be invoked.

\footnotetext{
${ }^{25}$ As Nancy Scheper-Hughes (1998: 123-124) argues, there is an injustice discernable in attempting to make meaningful the suffering of others. Following Levinas, she suggests that we ought to understand suffering as evil and absurd. Therefore, any attempt to account for the other's suffering is immoral. We may attribute meaning to our own suffering but we can only understand the suffering of the other as evil and tragic.
}

${ }^{26}$ As Veitch (1999: 155) puts it, the institution of a common memory is 'always in danger of failing to recognise, or even of deliberately suppressing divergent commonalities that cannot be reduced to or which in fact cut across the creation of the collective.' 
Reconciliation needs redeeming narratives. It must seek to reveal the past as a network of related events that might provide a basis from which members of a political association can reconcile themselves to the irrevocable consequences of action. It is only by coming to terms with the past in this way that the new beginning political reconciliation seeks to establish might be memorialised. At the same time, it must resist the tendency to bring about a final closure - to let the past 'become simply the historical past, the past perfect' (Booth 2001: 788). ${ }^{27}$ To avoid doing violence to the memory of victims, a reconciliatory politics must retain a sense of the unacknowledgeability of suffering, of what is unspeakable but at the same time demands acknowledgement. As Perrin and Veitch (1998: 232) point out, we cannot acknowledge what is unacknowledgeable but we can acknowledge the fact that it is unacknowledgeable.

Just as the community that political reconciliation seeks to constitute must remain always not yet, so the task of remembrance must be always unfinished. Any closure that a redemptive narrative helps to bring about must remain provisional. For since the past is not static but a constantly shifting horizon in which we move and that moves with us, so the past reveals itself in a new light according to our present situation. Remembrance of past wrongs, then, will continue to unsettle our attempts at reconciliation as new aspects of old injustices are revealed to future generations. As Arendt observes, the past can never be mastered. Rather, she suggests, 'the best that can be achieved is to know precisely what was, and to endure this knowledge and then to wait and see what comes of knowing and enduring' (MDT: 20). And yet, given the limits of narrative - that a painful past may remain unsusceptible to narration - even this may be asking too much. We must try to know, yes, and we must endure. Moreover, we cannot know where such a reckoning with the past will lead us. However, we must avoid presuming that we could ever adequately acknowledge the past. For to do so would not only be an injustice to the dead, but would undercut reconciliation in the present by consigning the past to history rather than memory.

\footnotetext{
${ }^{27}$ As Mario Di Paolantonio (1997: 454) argues, 'To say that we have explored, catalogued, and finally "know" the "facts" of the past is inevitably to reduce the otherness of the past to that which the present is already familiar with. In this sense, history is ossified within the norms and conventions of the present; it could very well be, then, that pasts that exceed or inconvenience the present would have no recognition in this scheme.'
} 


\section{Conclusion}

If reconciliation is to be conceived politically, I suggested in chapter five, it must be conditioned by an awareness of its own impossibility. Consequently, it is a political mistake to think of reconciliation in terms of the restoration of moral community. For, on this account, the transmundane memory of a prepolitical community is posited as an ideal future possibility toward which the existing political association should be brought as close as possible. The telos of a harmonious community (in which politics has been overcome once and for all) provides the rule by which the success of reconciliation in the present is gauged. But positing reconciliation as the ultimate end of politics in this way obscures the political nature of the terms within which it is enacted - the exclusions on which it is predicated. By contrast, attending to the risk that a conflict might turn out to be irreconcilable brings the politics of reconciliation back into view.

Since it takes a relation of antagonism between enemies (rather than one of alienation between co-members) as its starting point, this account of political reconciliation is underpinned by an awareness of the frailty and contingency of community. The aspiration to reconcile enables politics in the present by constituting a potential horizon in terms of which citizens of a divided polity might reckon with the past. Yet to the extent that this future ideal is actualised it would undercut such a reconciliatory politics by overcoming the conditions of plurality and contingency that constitute its possibility in the present. In this sense, reconciliation is, as Mouffe (2000: 137) suggests, 'a good that exists as good only as long as it cannot be reached.' While a shared faith in reconciliation conditions the possibility of politics in the present, politics must be invoked to resist the moment of closure that reconciliation might otherwise tend towards. As such, political reconciliation entails a fragile holding together of the world-delimiting and world- 
rupturing moments of politics. Moreover, it proceeds in an inverse sequence to that which we presuppose according to our ordinary moral intuitions.

Political reconciliation is initiated, as I showed in chapter six, not by invoking an ideal image of community that should be restored but by conceiving the present as the moment from which a future community might understand itself to have originated. As such, political reconciliation is impelled by an anticipated remembrance that becomes available by constituting a space for politics within which conflicting memories and expectations can be brought to bear on each other. The world-rupturing moment of constitution consists in acting in concert to establish a new beginning in the present. The world-delimiting moment of constitution consists in the effort to memorialise this beginning by promising 'never again.' While the possibility of community emerges in the moment of beginning it remains utterly fragile in the absence of the shared expectations that promising establishes. Yet the contingency of the beginning must be invoked in order to resist the tendency of a legal constitution to overdetermine the terms of reconciliation by re-presenting community as always already rather than recognising it as an ever-present possibility that is brought to presence through collective action.

If promising mitigates the risks arising from the unpredictability of action by establishing shared expectations, forgiveness mitigates the risks associated with its irreversibility by preventing the past from determining the possibilities of the present. Wanting to forgive helps sustain the space for a reconciliatory politics that constitution establishes by interrupting a negative, re-active process that threatens to undermine the fragile web of human relationships. In the world-delimiting moment of forgiveness, trust is ventured in advance for the sake of the fragile inter-space that is shared with one's transgressor. The judgement that our historical relation to the other confirms her as our enemy in the present is suspended. In its worldrupturing moment, forgiveness releases the other from the consequences of her actions in order to enable her to act anew. As such, forgiveness has a miraculous quality because it does not simply re-act but responds to the other in a manner that is unexpected. When animated by care for what is fragile, forgiveness delimits the world that lies between former enemies. In this sense, it calls the other to account by acknowledging that she is in need 
of forgiveness. On the other hand, it invites our transgressor to respond by entering into a potentially world-disclosing politics. By releasing her from the consequences of her actions it frees her to call this world into question

Forgiveness thus clears the way for the assumption of political responsibility. This vicarious responsibility arises due to the boundlessness of action, which implicates us in injustice as both doers and sufferers. In its world-delimiting moment, political responsibility entails the shameful acknowledgement of an obligation to repair the harm that was wrongfully inflicted. Reparation implicitly acknowledges the other as co-builder of a common world who is entitled to respectful treatment. In its world-rupturing moment, however, political reconciliation entails a responsiveness to the other, the will to live together in the mode of acting and speaking. In assuming political responsibility, then, we do not so much hope for forgiveness and redemption than that the other will join us in the risky venture of realising a world in common. In its world-delimiting moment, responsibility seeks to repair the fragile world that lies between perpetrator and victim. Yet, given the boundlessness of action, care for the world threatens to overwhelm and thus prevent us from acting for fear of being implicated in further injustice. In its world-rupturing moment, political responsibility requires that we accept this risk - the possibility that an agonistic encounter with the other will confirm a relation of enmity - in the hope that it might initiate a new relationship.

Acknowledgement of the moral truth of wrongdoing is not a precondition for reconciliation, then, but rather reconciliation makes possible a collective remembrance of past wrongs. The invocation of a community that is 'not yet' establishes a context within which it is possible that a shared understanding of what went before might emerge. This coming to terms with the past is sustained by wanting to forgive and kept in play by the assumption of political responsibility. It is in this way that the invocation of a "we" that is not yet makes available a past to look forward to; that is, a collective past that never was but can only appear so in the light of a community that is yet to be. In its world-delimiting moment, remembrance reveals our isolated doings and sufferings as part of a network of related events as represented in a coherent narrative. In its world-rupturing moment it entails a monumental regard for the past, according to which we attend to 
those moments of greatness that attest to the possibilities of action in the present. In its world-delimiting moment, remembrance redeems the past by revealing our acts as part of a significant whole. Yet, it also threatens to appropriate the singularity of experience by determining their meaning in relation to the telos of reconciliation. Against this tendency, the worldrupturing moment of remembrance reveals the extent to which the past is not independent of us but emerges from our present concerns with action.

We have seen, then, that at each step on the way political reconciliation is confronted by the risk of politics: the possibility that the new beginning we seek to enact in the present will not come to pass. The fragile "we" that is constituted in the foundational act may disappear just as quickly as it appears on the scene of politics. The will to forgive is confronted by the prospect of the unforgivable. The boundlessness of action threatens to overstretch our capacity to assume a responsibility of care for the world. The possibility of a redemptive remembrance is challenged by what is unspeakable and immemorial.

Yet, in the face of all this, there is only politics to fall back on since institutional remedies that seek to contain these risks end up undercutting political reconciliation by forcing an unwarranted closure. The presupposition of a "we" that already is in constitutional discourse renders social conflict commensurable by reduction. Punishment is inadequate in the face of crimes that are unforgivable. An injustice is done in presuming the possibility of repairing what is irreparable. The memory of the victims is appropriated and 'redeemed' according to the telos of national unity. In these contexts, politics must be invoked to resist the moment of affirmative closure that reconciliation might otherwise tends toward. Politicising the terms within which reconciliation is enacted thus means recognising the contingency of community, recalling the virtual reciprocity of evil, acknowledging a debt that cannot be repaid, attending to the limits of memory. Political reconciliation thus always involves this constant back and forth between sustaining politics with the promise of reconciliation and holding open the horizon of reconciliation by attending to the risk of politics. 
This thesis has provided an opportunity to consider the issues surrounding transitional justice in the context of current debates about the nature of 'the political.' I have shown how Locke, Taylor, and (especially) Arendt help to illuminate the fundamental issues that reconciliation must address: the constitution of the political association, the possibility of forgiveness in politics, the nature of collective responsibility and the role of remembrance in sustaining a political identity. But, perhaps more interestingly, this thesis has provided an opportunity to reflect on the nature of the political in the light of the issues that transitional justice raises for political theory. It has provided an opportunity to consider the merits of various accounts of politics in terms of the "hard case" transitional justice presents: namely, a situation in which community cannot be presupposed as it often is in political theory. This context reveals the limits of liberal and communitarian understandings of politics. At the same time, it enables us to look on Arendt's work from a perspective that reveals the richness of many of her insights, which might otherwise escape our attention.

In appropriating Arendt's account of the political for a theory of political reconciliation I have understated some of the difficulties that are often observed in her work. For instance, I have referred only implicitly to several fundamental distinctions - i.e. between private and public, between the social and political, and between labour, work and action - around which her thought revolves. Arendt is often criticised for overdrawing and reifying these distinctions (e.g. Benhabib 1996; Kateb 1984; Pitkin 1998). It seems to me that these criticisms are often overstated. At any rate, the creative reading of Arendt's ethic of worldliness on which I rely in this thesis does not depend on these distinctions being drawn in the manner that is often imputed to Arendt.

More to the point, an aspect of Arendt's political theory that does have a direct bearing of transitional justice - to which critics such as Habermas (1977) and Dietz (1994) draw our attention - is her exclusion of violence and strategic action from the concept 'the political.' I have sought to acknowledge this aspect of politics in the theory of political reconciliation developed in terms of the 'risk of politics'. However, with Arendt, I have insisted on establishing a separation between this risk and 'the political' in the normative sense in which I have employed it through this thesis. 
Consequently, it might be suggested that I have failed to fully acknowledge the inevitable antagonism and ineradicable violence that is inherent to the political. Following from this, the kind of pluralism that I have insisted political reconciliation must celebrate implies the possibility of plurality without antagonism, of a friend without an enemy, an agonism without antagonism' (Mouffe 2000: 134).

Indeed, it does. For what I have affirmed here is an account of the political as ethical commitment: the will to live together with others in the mode of speaking and acting. In my view, Arendt is profoundly right in her insistence on the 'pure politics' for which she is often taken to task (e.g. Connolly 1997; Feldman 1999; Keenan 1994). For, if Arendt presents 'an image of true politics that often taunts us in its unavailability' (Kateb 1984: 28), this utopian aspiration is critical in order to affirm human freedom against the apolitical complacency of much contemporary political theory. Indeed, what is at stake in political reconciliation - the ethical constitution of a "we" - ultimately rests on that intangible quality of performative action that Arendt attempts to illuminate in all her work. In order to recognise this as a political possibility we need to clearly distinguish the political (as ethical commitment) from strategy, rule and violence.

While I want to insist on the importance of this distinction, the relation between politics and violence remains an intriguing but underdeveloped theme of my research. It thus remains to further interrogate, challenge, broaden and deepen the understanding of the political I have developed here by examining violence as a political phenomenon - as it emerges, for instance, in war, revolution, colonisation, torture, genocide, terrorism and institutions. In this context, I believe it would be fruitful to bring Arendt and Foucault into a conversation with the tradition of political realism (especially, Weber, Schmitt, Strauss) in order to consider in what sense violence might be understood to be political, whether violence can be meaningful and how our understanding of politics influences the way we view violence. This remains a task for future research. 


\section{References}

Ackerman, Bruce. 1992. The Future of the Liberal Revolution. New Haven: Yale University Press.

Adorno, Theodor W. 1986. 'What Does Coming to Terms with the Past Mean?' in G H Hartman (ed) Bitburg in Moral and Political Perspective. Bloomington: Indiana University Press.

Appiah, K. Anthony. 1994. 'Identity, Authenticity, Survival: Multicultural Societies and Social Reproduction' in A Gutmann (ed) Multiculturalism: Examining the Politics of Recognition. Princeton: Princeton University Press.

Arendt, Hannah. 1950. 'The Aftermath of Nazi Rule: Report from Germany,' Commentary, October: 342-353.

Arendt, Hannah. 1958. The Origins of Totalitarianism, second edition. London: Allen \& Unwin.

Arendt, Hannah. 1964. 'Personal responsibility under dictatorship,' The Listener. August 6: 185-187, 205.

Arendt, Hannah. 1965. On Revolution. London: Penguin.

Arendt, Hannah. 1968. Men in Dark Times. New York \& London: Harcourt Brace \& Company.

Arendt, Hannah. 1970. Crises of the Republic. New York \& London: Harcourt Brace Jovanovich.

Arendt, Hannah. 1971. 'Thinking and Moral Considerations: A Lecture,' Social Research 38(3): 417-446.

Arendt, Hannah. 1977. Eichmann in Jerusalem: A Report on the Banality of Evil. New York: Penguin Books. 
Arendt, Hannah. 1977. Between Past and Future: Eight Exercises in Political Thought. Harmondsworth: Penguin.

Arendt, Hannah. 1977. The Life of the Mind, one volume edition, Mary McCarthy (ed). New York \& London: Harcourt Brace \& Co.

Arendt, Hannah. 1978. The Jew as Pariah: Jewish Identity and Politics in the Modern Age. Ron H Feldman (ed), New York: Grove Press.

Arendt, Hannah. 1979. 'On Hannah Arendt' in M Hill (ed) Hannah Arendt: The Recovery of the Public World. New York: St Martin's Press.

Arendt, Hannah. 1982. Lectures on Kant's Political Philosophy, R Beiner (ed). Brighton: Harvester Press.

Arendt, Hannah. 1987. 'Collective Responsibility' in J Bernauer (ed) Amor Mundi: Explorations in the Faith and Thought of Hannah Arendt. Dordrecht: Martinus Nijhoff.

Arendt, Hannah. 1990. 'Philosophy and Politics,' Social Research 57(1): 73-103.

Arendt, Hannah. 1994. Essays in Understanding 1930-1954, J Kohn (ed). New York \& London: Harcourt Brace \& Co.

Arendt, Hannah. 1996. Love and Saint Augustine, J V Scott \& J C Stark (eds). Chicago \& London: University of Chicago Press.

Arendt, Hannah. 1998. The Human Condition, second edition. Chicago: University of Chicago Press.

Arendt, Hannah \& Karl Jaspers. 1992. Arendt-Karl Jaspers Correspondence 19261969, L Kohler \& H Saner (eds). New York \& London: Harcourt Brace Jovanovich.

Ashcraft, Richard. 1994. 'Locke's influence' in V Chappell (ed) The Cambridge Companion to Locke. Cambridge: Cambridge University Press.

Asmal, Kader. 1995. 'Kader Asmal' in A Boraine \& J Levy (eds) The Healing of a Nation? Capetown: Justice in Transition.

Asmal, Kader, Louise Asmal \& Ronald Suresh Roberts. 1996. Reconciliation through Truth: a reckoning of Apartheid's criminal governance. Oxford: James Currey Publishers. 
Bankowski, Zenon. 2002. 'Remorse and Reconciliation,' paper presented at the colloquium on Law, Time and Reconciliation, Centre for Law and Society, University of Edinburgh, 15-16 May.

Barnouw, Dagmar. 1990. Visible Spaces: Hannah Arendt and the German-Jewish Experience. Baltimore \& London: The John Hopkins University Press.

Bauman, Zygmunt. 2000. Modernity and the Holocaust, second edition. Cambridge: Polity.

Bauman, Zygmunt. 2001. 'The Great War of Recognition,' Theory, Culture $\mathcal{E}$ Society 18(2-3): 137-150.

Beiner, Ronald. 1982. 'Interpretive Essay: Hannah Arendt on Judging' in H Arendt, Lectures on Kant's Political Philosophy, R Beiner (ed). Brighton: Harvester Press.

Beiner, Ronald. 1984. 'Walter Benjamin's Philosophy of History,' Political Theory 12(3): 423-434.

Benhabib, Seyla. 1988. 'Judgment and the Moral Foundations of Arendt's Thought,' Political Theory 16(1): 29-51.

Benhabib, Seyla. 1994. 'Hannah Arendt and the Redemptive Power of Narrative' in LP Hinchman \& SK Hinchman (eds) Hannah Arendt: Critical Essays. Albany: State University of New York Press.

Benhabib, Seyla. 1996. The Reluctant Modernism of Hannah Arendt. London: Sage Publications.

Benjamin, Walter. 1992 [1955]. 'The Storyteller' and 'Theses on the Philosophy of History' in Illuminations, H Arendt (ed). London: Fontana.

Bennett, Christopher. 2002. 'The Varieties of Retributive Experience,' The Philosophical Quarterly 52(207): 145-163.

Bennett, Christopher. 2003. 'Is amnesty a collective act of forgiveness?,' Contemporary Political Theory 2(1).

Berlin, Isaiah. 1990. 'The pursuit of the idea' in H Hardy (ed) The Crooked Timber of Humanity. London: John Murray. 
Bernstein, Richard. 1986. 'Judging - the Actor and the Spectator' in Philosophical Profiles: Essays in a Pragmatic Mode. Cambridge: Polity Press.

Bernstein, Richard. 1996. Hannah Arendt and the Jewish Question. Cambridge: Polity Press.

Bilsky, Leora. 2001a. 'Justice or Reconciliation? The Politicisation of the Holocaust in the Kastner Trial' in E Christodoulidis \& S Veitch (eds) Lethe's Law: Justice, Law and Ethics in Reconciliation. Oxford \& Portland: Hart Publishing.

Bilsky, Leora. 2001b. 'Between Justice and Politics: The Competition of Storytellers in the Eichmann Trial' in S Aschheim (ed) Hannah Arendt in Jerusalem. Berkeley: University of California Press.

Biskowski, Lawrence J. 1993. 'Practical Foundations for Political Judgment: Arendt on Action and World,' The Journal of Politics 55(4): 867-887.

Black, Sam. 1998. 'Toleration and the Sceptical Inquirer in Locke,' Canadian Journal of Philosophy 28(4): 473-504.

Blight, David. 2001. Race and Reunion: the Civil War in American Memory. Cambridge, MA: Belknap Press.

Booth, James W. 1999. 'Communities of memory: on identity, memory, and debt,' American Political Science Review 93(2): 249-263.

Booth, James W. 2001. 'The Unforgotten: Memories of Justice,' American Political Science Review 95(4): 777-791.

Borneman, John. 1997. Settling Accounts: Violence, Justice, and Accountability in Postsocialist Europe. Princeton: Princeton University Press.

Bowen-Moore, Patricia. 1989. Hannah Arendt's Philosophy of Natality. Basingstoke: Macmillan.

Brooks, Roy L. 1999. 'The age of apology' in R Brooks (ed) When Sorry Isn't Enough: The Controversy over Apologies and Reparations for Human Injustice. New York \& London: New York University Press.

Buckler, Steve. 2001. 'The curtailment of memory: Hannah Arendt and postHolocaust culture,' The European Legacy 6(3): 287-303. 
Burns, Robert. 1987. 'Hannah Arendt's constitutional thought' in J Bernauer (ed) Amor Mundi: Explorations in the Faith and Thought of Hannah Arendt. Dordrecht: Martinus Nijhoff.

Buruma, Ian. 1994. Wages of Guilt: Memories of War in Germany and Japan. London: Random House.

Calhoun, Cheshire. 1992. 'Changing one's heart,' Ethics 103: 76-96.

Canovan, Margaret. 1992. Hannah Arendt: A Reinterpretation of Her Political Thought. Cambridge: Cambridge UP.

Canovan, Margaret. 1997. 'Hannah Arendt as a Conservative Thinker' in L May \& J Kohn (eds) Hannah Arendt: Twenty Years Later. Cambridge, MA: MIT Press.

Chandra-Shekeran, Sangeetha. 1998. 'Challenging the Fiction of the Nation in the 'Reconciliation' Texts of Mabo and Bringing Them Home,' Australian Feminist Law Review 11: 107-133.

Chen, Selina. 1998. 'Locke's Political Arguments for Toleration,' History of Political Thought 19(2): 167-185.

Christodoulidis, Emilios. 1998. Law and Reflexive Politics. Dordrecht: Kluwer Academic Publishers.

Christodoulidis, Emilios. 2000. ' 'Truth and Reconciliation' as Risks,' Social and Legal Studies 9(2): 179-204.

Christodoulidis, Emilios. 2001a. 'Law's Immemorial' in E. Christodoulidis \& S. Veitch, Lethe's Law. Oxford: Hart Publishing.

Christodoulidis, Emilios. 2001b. 'The Aporia of Sovereignty: On the Representation of the People in Constitutional Discourse,' King's College Law Journal 12: 111-133.

Christodoulidis, Emilios. forthcoming. 'Constitutional Irresolution: Law and the Framing of Civil Society,' European Law Journal.

Clark, Geoff. 2000. 'Not much progress' in M Grattan (ed) Reconciliation: Essays on Australian Reconciliation. Melbourne: Black Inc.

Cooke, Maeve. 1997. 'Authenticity and Autonomy: Taylor, Habermas and the Politics of Recognition.' Political Theory 25(2): 258-288. 
Coombe, Rosemary J. 1993. 'Tactics of Appropriation and the Politics of Recognition in Late Modern Democracies.' Political Theory 21(3): 411433.

Cooper, David. 2001. 'Collective Responsibility, "Moral Luck," and Reconciliation' in Aleksander Jokic (ed) War Crimes and Collective Wrongdoing: A Reader. Oxford: Blackwell.

Connerton, Paul. 1989. How Societies Remember. Cambridge: Cambridge University Press.

Connolly, William. 1993. The Terms of Political Discourse, third edition. London: Blackwell.

Connolly, William. 1997. 'A critique of pure politics,' Philosophy and Social Criticism 23(5): 1-26.

Creppel, Ingrid. 1996. 'Locke on Toleration: The Transformation of Constraint,' Political Theory 24(2): 200-240.

Crocker, David A. 1998. 'Transitional Justice and International Civil Society: Toward a Normative Framework,' Constellations 5(4): 492-517.

Crocker, David A. 1999. 'Reckoning with Past Wrongs: A Normative Framework,' Ethics and International Affairs 13: 43-64.

Crocker, David A. 2000. 'Retribution and Reconciliation,' Institute for Philosophy and Public Policy, University of Maryland, Winter-Spring Report, http:/ / www.puaf.umd.edu/IPPP.

Cunningham, Michael. 1999. 'Saying Sorry: The Politics of Apology,' Political Quarterly 70(3): 285-293.

d'Entrèves, Maurizio Passerin. 1994. The Political Philosophy of Hannah Arendt. Routledge: London \& New York.

de Brito, Alexandra Barahona, Carmen González-Enríquez \& Paloma Aguilar. 2001. 'Introduction' in A B De Brito, C González-Enríquez \& P Aguilar (eds) The Politics of Memory: Transitional Justice in Democratizing Societies. Oxford: Oxford University Press.

de Grieff, Pablo. 1996. 'Trial and Punishment: Pardon and Oblivion,' Philosophy and Social Criticism 22(3): 93-111. 
de Lange, Johnny. 2000. 'The historical context, legal origins and philosophical foundations of the South African Truth and Reconciliation Commission' in C Villa-Vicencio \& W Verwoerd (eds) Looking Back Reaching Forward: Reflections on the Truth and Reconciliation Commission of South Africa. London: Zed Books.

Di Paolantonio, Mario. 1997. 'Argentina After the "Dirty War": Reading the Limits of National Reconciliation,' Alternatives 22(4): 433-465.

Dallmayr, Fred 1997. 'The Politics of Nonidentity: Adorno, Postmodernism And Edward Said,' Political Theory 25(1): 33-56.

Derrida, Jacques. 1986. 'Declarations of Independence,' New Political Science 15: 7-15.

Dietz, Mary. 1994. "'The slow boring of hard boards": methodological thinking and the work of politics,' American Political Science Review 88(4): 873-886.

Dietz, Mary. 2000. 'Arendt and the Holocaust' in D Villa (ed) The Cambridge Companion to Hannah Arendt. Cambridge: Cambridge University Press.

Digeser, Peter. 1998. 'Forgiveness and Politics: Dirty Hands and Imperfect Procedures,' Political Theory 26(5): 700-724.

Dillon, Michael. 1999. 'Another Justice,' Political Theory 27(2): 155-175.

Dowdall, Terry. 1996. 'Psychological aspects of the Truth and Reconciliation Commission' in H R Botman \& R M Peterson (eds) To Remember and to Heal. Cape Town: Human \& Rousseau.

Dunn, John. 1984. Locke. Oxford: Oxford University Press.

Dunn, John. 1991. 'The claim to freedom of conscience: freedom of speech, freedom of thought, freedom of worship?' in P Grell, J Israel \& N Tyacke (eds) From Persecution to Toleration: The Glorious Revolution and Religion in England. Oxford: Clarendon Press.

Duvenage, Peter. 1999. 'The politics of memory and forgetting after Auschwitz and apartheid,' Philosophy and Social Criticism 25(3): 1-28. 
Elshtain, Jean Bethke. 2001. 'Politics and Forgiveness' in N Biggar (ed) Burying the Past: Making Peace and Doing Justice after Civil Conflict. Washington, D.C.: Georgetown University Press.

Fanon, Frantz. 1965. The Wretched of the Earth. London: Macgibbon \& Kee.

Fanon, Frantz. 1967. 'Racism and Culture' in Toward the African Revolution. New York \& London: Monthly Review Press.

Fanon, Frantz. 1986. Black Skin, White Masks. London: Pluto Press.

Feinberg, Joel. 1991. 'Collective Responsibility' in L May \& S Hoffman (eds) Collective Responsibility: Five Decades of Debate in Theoretical and Applied Ethics. Savage: Rowman \& Littlefield Publishers

Feldman, Leonard C. 1999. 'Political Judgment with a Difference: Agonistic Democracy and the Limits of "Enlarged Mentality",' Polity 32(1): 1-24.

Ferrara, Alessandro. 1998. 'Judgment, identity and authenticity: a reconstruction of Arendt's interpretation of Kant,' Philosophy and Social Criticism 24(2/3): 113-136.

Fives, Allyn. 2001. A Hermeneutic Defence of Social Citizenship. PhD dissertation, Politics, University of Edinburgh.

Foucault, Michel. 1984. 'Nietzsche, Genealogy, History' in P Rainbow (ed) The Foucault Reader. New York: Pantheon.

Fraser, Nancy. 2001. 'Recognition Without Ethics,' Theory, Culture \& Society 18(2-3): 21-42.

Gadamer, Hans-Georg. 1986. 'The historicity of understanding' in K MuellerVollmer (ed) The Hermeneutics Reader. Oxford: Blackwell.

Gaita, Raimond. 1999. A Common Humanity: Thinking About Love and Truth and Justice. Melbourne: Text Publishing.

Galeotti, Anna Elisabetta. 1993. 'Citizenship and Equality: The Place for Toleration,' Political Theory 21(4): 585-605.

Galeotti, Anna Elisabetta. 1994. 'A Problem with Theory: A Rejoinder to Moruzzi,' Political Theory 22(4): 673-677. 
Gallie, W,B. 1969. 'Essentially Contested Concepts' in M Black (ed) The Importance of Language. London: Cornell.

Garton Ash, Timothy. 1997. 'True Confessions,' The New York Review of Books, 17 July: 33-38.

Gilbert, Margaret. 2001. 'Collective Remorse' in A Jokic (ed) War Crimes and Collective Wrongdoing: A Reader. Oxford: Blackwell.

Gillis, John R. 1994. 'Memory and Identity: The History of a Relationship' in J R Gillis (ed) Commemorations. Princeton, NJ: Princeton University Press.

Gough, J W (1991) 'The development of Locke's belief in toleration' in S Mendus \& J Horton (eds) John Locke: A Letter Concerning Toleration in Focus. London: Routledge.

Govier, Trudy. 1999. 'Forgiveness and the Unforgivable,' American Philosophical Quarterly 36(1): 59-75.

Govier, Trudy \& Wilhelm Verwoerd. 2002. 'Trust and the Problem of National Reconciliation,' Philosophy of the Social Sciences 32(2): 178-205.

Grattan, Michelle. 2000. 'Introduction' in M Grattan (ed) Reconciliation: Essays on Australian Reconciliation. Melbourne: Black Inc.

Graybill, Lyn S. 1998. 'South Africa's Truth and Reconciliation Commission: Ethical and Theological Perspectives', Ethics and International Affairs 12: 43-62.

Gutmann, Amy \& Dennis Thompson. 2000. 'The Moral Foundations of Truth Commissions' in R Rotberg \& D Thompson (eds) Truth $v$ Justice: the Morality of Truth Commissions. Princeton, NJ: Princeton University Press.

Habermas, Jürgen. 1977. 'Hannah Arendt's Communications Concept of Power,' Social Research 44(1): 2-24.

Habermas, Jürgen. 1994. 'Struggles for Recognition in the Democratic Constitutional State' in A Gutmann (ed) Multiculturalism: Examining the Politics of Recognition. Princeton: Princeton University Press. 
Habermas, Jürgen \& Adam Michnik. 1994. 'Overcoming the Past,' New Left Review 203: 3-16.

Halbwachs, Maurice. 1992 [1941/1952]. On Collective Memory. Chicago \& London: University of Chicago Press.

Hamber, Brandon \& Hugo van der Merwe. 1998. 'What is this thing called reconciliation?,' paper presented at the Goedgedacht Forum 'After the Truth and Reconciliation Commission,' Goedgedacht Farm, Cape Town, 28 March. http:/ / sunsite.wits.ac.za/csvr/artrcb\&h.htm]

Hampton, Jean. 1988a. 'Forgiveness, resentment and hatred' in J Murphy \& J Hampton Forgiveness and Mercy. Cambridge: Cambridge University Press.

Hampton, Jean. 1988b. 'The retributive idea' in J Murphy \& J Hampton Forgiveness and Mercy. Cambridge: Cambridge University Press.

Hayner, Priscilla B. 2002. Unspeakable Truths: Confronting State Terror and Atrocity. New York \& London: Routledge.

Hegel, G.W.F. 1977 [1807]. Phenomenology of Spirit. Oxford: Oxford University Press.

Herman, Judith. 1992. Trauma and Recovery. New York: Basic Books.

Herzog, Annabel. 2000. 'Illuminating inheritance: Benjamin's influence on Arendt's political storytelling,' Philosophy and Social Criticism 26(5): 127.

Hieronymi, Pamela. 2001. 'Articulating an Uncompromising Forgiveness,' Philosophy and Phenomenological Research 62(3): 529- 555.

Holmes, Stephen. 1988a. 'Gag Rules or the Politics of Omission' in J Elster \& R Slagstad (eds) Constitutionalism \& Democracy. Cambridge: Cambridge University Press.

Holmes, Stephen. 1988b. 'Precommitment and the paradox of democracy' in J Elster \& R Slagstad (eds) Constitutionalism and Democracy. Cambridge: Cambridge University Press.

Honig, Bonnie. 1988. 'Arendt, Identity and Difference,' Political Theory 16(1): 77-98. 
Honig, Bonnie. 1991. 'Declarations of Independence: Arendt and Derrida on the Problem of Founding a Republic,' American Political Science Review, 85(1): 97-114.

Honig, Bonnie. 1992. 'Toward an Agonistic Feminism: Hannah Arendt and the Politics of Identity' in J. Butler \& J.W. Scott (eds) Feminists Theorize the Political. New York \& London: Routledge.

Honohan, Iseult. 1990. 'Arendt and Benjamin on the Promise of History: A Network of Possibilities or One Apocalyptic Moment?,' Clio 19(4): 311-330.

Honneth, Axel. 1995. The Struggle for Recognition: The Moral Grammar of Social Conflicts. (trans. Joel Anderson) Cambridge: Polity Press.

Honneth, Axel. 2001. 'Recognition or Redistribution? Changing Perspectives on the Moral Order of Society,' Theory, Culture \& Society 18(2-3): 43-56.

Howard, John. 2000. 'Practical Reconciliation' in M Grattan (ed) Reconciliation: Essays on Australian Reconciliation. Melbourne: Black Inc.

Humphrey, Michael. 2000. 'From Terror to Trauma: Commissioning Truth for National Reconciliation,' Social Identities 6(1): 7-27.

Huntington, Samuel P. 1991. The Third Wave: Democratization in the Twentieth Century. Norman: University of Oklahoma Press.

Hutchings, Kimberly. 1996. Kant, Critique and Politics. London \& New York: Routledge.

Ignatieff, Michael. 1996. 'Articles of faith,' Index on Censorship 25(5): 110-122.

Ignatieff, Michael. 1999. 'Nationalism and toleration' in S Mendus (ed) The Politics of Toleration: Tolerance and Intolerance in Modern Life. Edinburgh: Edinburgh University Press.

Jaspers, Karl. 1961 [1947]. The Question of German Guilt. New York: Capricorn Books.

Kateb, George. 1984. Hannah Arendt: Politics, Conscience, Evil. Oxford: Martin Robertson. 
Kateb, George. 2000. 'Political action: its nature and advantages' in D Villa (ed) The Cambridge Companion to Hannah Arendt. Cambridge: Cambridge University Press.

Keating, Paul. 2000. 'The Redfern Park Speech' in M Grattan (ed) Reconciliation: Essays on Australian Reconciliation. Melbourne: Black Inc.

Keenan, Alan. 1994. 'Promises, Promises: The Abyss of Freedom and the Loss of the Political in the Work of Hannah Arendt,' Political Theory 22(2): 297-322.

Kelly, Erin \& Lionel McPherson. 2001. 'On Tolerating the Unreasonable,' The Journal of Political Philosophy 9(1): 38-55.

Kelly, P.J. 1991 'Authority, Conscience and Religious Toleration' in S Mendus \& J Horton (eds) John Locke: A Letter Concerning Toleration in Focus. London: Routledge.

Kerruish, Valerie \& Jeannine Purdy. 1998. 'He "Look" Honest - Big White Thief', Law/Text/Culture 4(1): 146-

Kiss, Elizabeth. 1998. 'Saying we're sorry: liberal democracy and the rhetoric of collective identity,' Constellations 4(3): 387-398.

Kitchen, Gary. 1999. 'Charles Taylor: The malaises of modernity and the moral sources of the self,' Philosophy and Social Criticism 25(3): 29-55.

Kojève, Alexandre. 1980. Introduction to the Reading of Hegel: Lectures on the Phenomenology of Spirit. Ithaca \& London: Cornell University Press.

Köker, Levent. 1996. 'Political Toleration or Politics of Recognition: The Headscarves Affair Revisited' Political Theory 24(2): 315-320.

Kolnai, Aurel. 1977. 'Forgiveness' in Ethics, Value and Reality. London: The Athlone Press.

Kraynak, Robert. 1980. 'John Locke: From Absolutism to Toleration,' American Political Science Review 74(1): 53-69.

Kritz, Neil J. (ed) 1995. Transitional Justice: How Emerging Democracies Reckon with Former Regimes. Volume I: General Considerations. Washington D.C.: United States Institute of Peace Press. 
Krog, Antjie. 1998. Country of my Skull. Johannesburg: Random House South Africa.

Kruks, Sonia. 1996. 'Fanon, Sartre, and Identity Politics' in L R Gordon, T D Sharpley-Whiting \& R T White (eds) Fanon: A Critical Reader. Oxford: Blackwell Publishers.

Levi, Primo. 1986. 'The memory of offence' in G H Hartman (ed) Bitburg in Moral and Political Perspective. Bloomington: Indiana University Press.

Little, Graham. 2001. The Public Emotions: From Mourning to Hope. Sydney: ABC Books.

Locke, John. 1975 [1690]. An Essay Concerning Human Understanding, P H Nidditch (ed). Oxford: Clarendon Press.

Locke, John. 1988 [1689]. Two Treatises of Government, P Laslett (ed). Cambridge: Cambridge University Press.

Locke, John. 1991 [1689]. 'A letter concerning toleration' in J Horton \& S Mendus (eds) John Locke: A Letter Concerning Toleration in Focus. Routledge: London \& New York.

Locke, John. 1997 [1667]. Political Essays, M Goldie (ed). Cambridge: Cambridge University Press.

Lowe, E J. (1995) Locke on Human Understanding. London: Routledge.

McAdams, A James. 2001. Judging the Past in Unified Germany. Cambridge: Cambridge University Press.

McClure, Kirstie M. 1998. 'Speaking in Tenses: Narrative, Politics, and Historical Writing,' Constellations 5(2): 234-249.

MacIntyre, Alasdair. 1985. After Virtue: a study in moral theory, second edition. London: Duckworth.

Maier, Charles S. 1988. The Unmasterable Past: History, Holocaust and German National Identity. Cambridge, MA: Harvard University Press.

Manderson, Desmond. 1998. 'Unutterable shame/Unuttered Guilt: Semantics, Aporia and the Possibility of Mabo,' Law, Text, Culture 4(1): 225-232. 
Mann, Michael. 1999. 'The Dark Side of Democracy: The Modern Tradition of Ethnic Cleansing,' New Left Review 235: 18-45.

May, Larry. 1991. 'Metaphysical Guilt and Moral Taint' in L May \& S Hoffman (eds) Collective Responsibility: Five Decades of Debate in Theoretical and Applied Ethics. Savage: Rowman \& Littlefield Publishers.

Meier, Heinrich. 1995. Carl Schmitt and Leo Strauss: The Hidden Dialogue, trans. JH Lomax. Chicago \& London: University of Chicago Press.

Memmi, Albert. 1990. The Coloniser and the Colonised. London: Earthscan Publications.

Mendus, Susan. 1989. Toleration and the Limits of Liberalism. Basingstoke: Macmillan.

Milliken, Robert. 2000. 'A new confidence' in M Grattan (ed) Reconciliation: Essays on Australian Reconciliation. Melbourne: Black Inc.

Minnow, Martha. 1998. Between Vengeance and Forgiveness: Facing History after Genocide and Mass Violence. Boston: Beacon Press.

Modjeska, Drusilla. 2000. 'A Bitter Wind' in M Grattan (ed) Reconciliation: Essays on Australian Reconciliation. Melbourne: Black Inc.

Moon, Claire. 2000. 'Prelapsarian State: The Metaphor of Reconciliation in South Africa,' paper presented at Political Studies Association conference, London School of Economics, 10-15 April.

Moon, Claire. 2002. 'Unspeakable. Torture: Making (Non)Sense of Narrative,' paper presented at the colloquium on Law, Time and Reconciliation, Centre for Law and Society, University of Edinburgh, 15-16 May.

Moore, John. 1999. 'Some Notes on Political Apology,' Social Politics Paper No.1. London: University of East London.

Morris, Herbert. 1976. On Guilt and Innocence: Essays in Legal Philosophy and Moral Psychology. Berkeley: University of California Press.

Moruzzi, Norma Claire. 1994. 'A Problem with Headscarves: Contemporary Complexities of Political and Social Identity,' Political Theory 22(4): 653-672. 
Mouffe, Chantal. 1999. 'Deliberative Democracy or Agonistic Pluralism?,' Social Research 66(3): 745-758.

Mouffe, Chantal. 2000. The Democratic Paradox. London \& New York: Verso.

Müller-Farenholz, Geiko. 1997. The Art of Forgiveness: Theological Reflections on Healing and Reconciliation. Geneva: World Council of Churches.

Murphy, Jeffrie. 1988. 'Forgiveness and resentment' in J. Murphy \& J. Hampton Forgiveness and Mercy. Cambridge: Cambridge University Press.

Nicholson, Linda. 1996. 'To be or not to be: Charles Taylor and the politics of recognition,' Constellations 3(1): 1-16.

Nietzsche, Friedrich. 1983 [1874]. 'On the Uses and Abuses of History for Life' in Untimely Meditations, trans. RJ Hollingdale. Cambridge: Cambridge University Press.

North, Joanna. 1987. 'Wrongdoing and Forgiveness,' Philosophy 62: 449-508.

Norval, Aletta J. 1998. 'Memory, Identity and the (Im)possibility of Reconciliation: The Work of the Truth and Reconciliation Commission in South Africa,' Constellations 5(2): 250-265.

Norval, Aletta. 1999. 'Truth and Reconciliation: the Birth of the Present and the Reworking of History,' Journal of Southern African Studies 25(3): 499-519.

Novitz, David. 1998. 'Forgiveness and Self-Respect,' Philosophy and Phenomenological Research 58(2): 299-315.

Nussbaum, Martha. 1996. 'Compassion: the basic social emotion,' Social Philosophy and Policy 13: 27-58.

Olick, Jeffrey K. \& Levy Daniel. 1997. 'Collective Memory and Cultural Constraint: Holocaust Myth and Rationality in German Politics,' American Sociological Review 62(6): 921-936.

Osiel, Mark. 1997. Mass Atrocity, Collective Memory and the Law. New Brunswick \& London: Transaction Publishers.

Perrin, Colin \& Scott Veitch. 1998. 'The Promise of Reconciliation,' Law, Text, Culture 4(1):225-232. 
Pitkin, Hanna Fenichel. 1998. The attack of the blob: Hannah Arendt's concept of the social. Chicago : University of Chicago Press.

Povinelli, Elizabeth A. 1998. 'The cunning of recognition: real being and Aboriginal recognition in settler Australia', Australian Feminist Law Journal 11 (October): 3-27.

Prager, Jeffrey. 1998. Presenting the Past: Psychoanalysis and the Sociology of Misremembering. Cambridge, MA: Harvard University Press.

Prager, Jeffrey. 2001a. 'Human Frailty and Lost Generations: The Intergenerational Transmission of Trauma,' paper presented at Human Frailty: Rights, Ethics and the Search for Global Justice, Centre for Critical Theory, University of West England. Bristol,. September.

Prager, Jeffrey. 2001b. 'Collective Memory' in N J Smelser \& P B Baltes (eds) International Encyclopaedia of the Social and Behavioural Sciences. Oxford: Pergamon.

Pribán, Jirí. 2002. 'Constitutional Justice and Retroactivity of Laws in Postcommunist Central Europe,' paper presented at the colloquium on Law, Time and Reconciliation, Centre for Law and Society, University of Edinburgh, 15-16 May.

Rabinbach, Anson. 1986. 'Introduction: Reflections on Germans and Jews since Auschwitz' in A Rabinbach \& J Zipes (eds) Germans and Jews since the Holocaust: the Changing Situation in West Germany. Holmes \& Meier: New York \& London.

Rabinbach, Anson. 1996. 'The German as pariah: Karl Jaspers and the Question of German Guilt,' Radical Philosophy 75: 15-25.

Rasch, William. 2000. 'Conflict as a Vocation: Carl Schmitt and the Possibility of Politics,' Theory, Culture and Society 17(6): 1-32.

Rawls, John. 1999. A Theory of Justice, revised edition. New York: Oxford University Press.

Reuter, Lutz R. 1990. 'Political and Moral Culture in West Germany: Four Decades of Democratic Reorganisation and Vergangenheitsauseinandersetzung,' in K Harms, L Reuter \& V Dürr 
(eds) Coping with the Past: Germany and Austria after 1945. Madison: University of Wisconsin Press.

Ricoeur, Paul. 1981. 'Narrative Time' in W.J.T. Mitchell (ed) On Narrative. Chicago \& London: University of Chicago Press.

Ricoeur, Paul. 1983. 'Action, Story and History: On Re-reading The Human Condition,' Salmagundi 60: 60-72.

Ricoeur, Paul. 2000. 'The concept of responsibility' in The Just. Chicago: University of Chicago Press.

Rowse, Tim. 2002. 'Treaty Talk 2002: Notes on three conferences,' Arena Magazine 62 (Dec): 30-37.

Said, Edward W. 1978. Orientalism. London \& Henley: Routledge \& Kegan Paul.

Sartre, Jean-Paul. 1963. Black Orpheus. S.W. Allen (trans.), Paris: Editions Gallimard.

Sartre, Jean-Paul. 1970. Anti-Semite and Jew. trans. George J. Becker. New York: Schocken Books.

Scanlon, T.M. 1996. 'The Difficulty of Tolerance' in D Heyd (ed) Toleration: an Elusive Virtue. Princeton, NJ: Princeton University Press.

Schaap, Andrew. 2000. 'Power and Responsibility: Should We Spare the King's Head?,' Politics 20(3): 129-135.

Schaap, Andrew. 2001. 'Guilty Subjects and Political Responsibility: Jaspers, Arendt and the resonance of the "German question" in politics of reconciliation,' Political Studies 49(4): 749-766.

Schaap, Andrew. 2003. 'Political Grounds for Forgiveness,' Contemporary Political Theory 2(1): 77-87.

Scheper-Hughes, Nancy. 1998. 'Undoing: Social Suffering and the Politics of Remorse in the New South Africa,' Social Justice 25(4): 114-142.

Schmitt, Carl. 1985 [1922]. 'Definition of Sovereignty' in Political Theology: Four Chapters on the Concept of Sovereignty. Cambridge, MA: MIT Press. 
Schmitt, Carl. 1996 [1932]. The Concept of the Political. Chicago: University of Chicago Press.

Schneewind, J.B. 'Locke's moral philosophy' in V Chappell (ed) The Cambridge Companion to Locke. Cambridge: Cambridge University Press.

Schudson, Michael. 1989. 'The Present in the Past versus the Past in the Present,' Communication 11: 105-113.

Schwan, Gesine. 1998. 'Political Consequences of Shared Guilt,' Constellations 5(4): 472-491.

Shklar, Judith N. 1989. 'The Liberalism of Fear' in N Rosenblum (ed) Liberalism and the Moral Life. Cambridge, MA: Harvard University Press.

Shklar, Judith N. 1998. 'Rethinking the past' in Political Thought and Political Thinkers. Chicago: University of Chicago Press.

Soyinka, Wole. 1999. The Burden of Memory, The Muse of Forgiveness. New York: Oxford University Press.

Sparrow, Robert. 2000. 'History and Collective Responsibility,' Australasian Journal of Philosophy 78(3): 346-359.

Starman, Hannah. 1999. 'Trauma and Identity: Israel and the Holocaust,' paper presented at Contesting Identities postgraduate conference, University of Edinburgh, 26-27 November.

Strauss, Leo. 1996. 'Notes on Carl Schmitt, The Concept of the Political' in G Schwab (ed), C Schmitt, The Concept of the Political, trans. J H Lomax. Chicago: University of Chicago Press.

Tamineaux, Jacques. 2000. 'Athens and Rome' in D. Villa (ed) The Cambridge Companion to Hannah Arendt. Cambridge: Cambridge University Press.

Tavuchis, Nicholas. 1991. Mea Culpa: A Sociology of Apology and Reconciliation. Stanford: Stanford University Press.

Taylor, Charles. 1975. Hegel. Cambridge: Cambridge University Press.

Taylor, Charles. 1979. Hegel and Modern Society. Cambridge: Cambridge University Press. 
Taylor, Charles. 1985a. Philosophical Papers 1: Human Agency and Language. Cambridge: Cambridge University Press.

Taylor, Charles. 1985b. Philosophical Papers 2: Philosophy and the Human Sciences. Cambridge: Cambridge University Press.

Taylor, Charles. 1989. Sources of the Self: The Making of Modern Identity. Cambridge: Cambridge University Press.

Taylor, Charles. 1991. The Ethics of Authenticity. Cambridge, MA: Harvard University Press.

Taylor, Charles. 1994. Reconciling the Solitudes: Essays on Canadian Federalism and Nationalism, G Laforest (ed). Montreal \& Kingston: McGill-Queen's University Press.

Taylor, Charles. 1995. Philosophical Arguments. Cambridge, MA: Harvard University Press.

Taylor, Charles \& Philippe de Lara. 1998. 'From Philosophical Anthropology to the Politics of Recognition: An Interview with Charles Taylor,' Thesis Eleven 52: 103-112.

Teitel, Ruti. 2000. Transitional Justice. Oxford and New York: Oxford University Press.

Thompson, Janna. 2002. Taking Responsibility for the Past: Reparation and Historical Justice. Cambridge: Polity Press.

Trumper, Ricardo. 1999. "Healing" the Social Body: Silence, Terror, and (Re)Conciliation in Neoliberal Chile,' Alternatives 24: 1-37.

Tully, James. 1993. An Approach to Political Philosophy: Locke in Contexts. Cambridge: Cambridge University Press.

Tully, James. 1995. Strange Multiplicity: Constitutionalism in an Age of Diversity. Cambridge: Cambridge University Press.

Tully, James. 2002. 'The Unfreedom of the Moderns in Comparison to Their Ideals of Constitutional Democracy,' The Modern Law Review 65(2): 204-228.

Tutu, Desmond. 1999. No Future Without Forgiveness. New York: Doubleday. 
Twambley, P. 1976. 'Mercy and Forgiveness,' Analysis 36: 84-90.

Van Roermund, Bert. 2001. 'Rubbing Off and Rubbing On: The Grammar of Reconciliation' in E Christodoulidis \& S Veitch (eds) Lethe's Law: Justice, Law and Ethics in Reconciliation. Oxford \& Portland: Hart Publishing.

Van Roermund, Bert. 2002. 'Never again,' paper presented at the colloquium on Law, Time and Reconciliation, Centre for Law and Society, University of Edinburgh, 15-16 May.

Veitch, Scott. 1999. 'Pro Patria Mori: Law, Reconciliation and the Nation' in D Manderson (ed) Courting Death: The Law of Mortality. London: Pluto Press.

Veitch, Scott. 2001. 'The Legal Politics of Amnesty' in E Christodoulidis \& S Veitch, Lethe's Law. Oxford: Hart Publishing.

Villa, Dana. 1996. Arendt and Heidegger: The Fate of the Political. Princeton: Princeton University Press.

Villa, Dana. 1999. Philosophy, Politics, Terror: Essays on the Thought of Hannah Arendt. Princeton: Princeton University Press.

Villa, Dana. 2001. 'Totalitarianism, Modernity and the Tradition' in SE Aschheim (ed) Hannah Arendt in Jerusalem. Berkeley: University of California Press.

Villa-Vicencio, Charles. 2000. 'Restorative justice: dealing with the past differently' in C Villa-Vicencio \& W Verwoerd (eds) Looking Back Reaching Forward: Reflections on the Truth and Reconciliation Commission of South Africa. London: Zed Books.

Villa-Vicencio, Charles \& Wilhelm Verwoerd. 2000. 'Introduction' in C VillaVicencio \& W Verwoerd (eds) Looking Back Reaching Forward: Reflections on the Truth and Reconciliation Commission of South Africa. London: Zed Books.

Vollrath, Ernst. 1977. 'Hannah Arendt and the Method of Political Thinking', Social Research 44(1): 160-182. 
Waldron, Jeremy. 1991. 'Locke: Toleration and the rationality of persecution' in S Mendus \& J Horton (eds) John Locke: A Letter Concerning Toleration in Focus. London: Routledge.

Waldron, Jeremy. 1992. 'Superseding Historic Injustice,' Ethics 103: 4-28.

Waldron, Jeremy. 2000. 'Arendt's constitutional politics' in D. Villa (ed) The Cambridge Companion to Hannah Arendt. Cambridge: Cambridge University Press.

Walzer, Michael. 1997. On Toleration. New Haven \& London: Yale University Press.

Weber, Max. 1948. 'Politics as a Vocation' in From Max Weber: Essays in Sociology, trans. HH Gerth \& W Mills. London: Routledge \& Kegan Paul.

Weinstock, Daniel M. 1994. 'The political theory of strong evaluation' in J Tully (ed) Philosophy in an age of pluralism: The philosophy of Charles Taylor in question. Cambridge: Cambridge University Press.

Williams, Gareth. 1998. 'Love and Responsibility: a Political Ethic for Hannah Arendt,' Political Studies 46(5): 937-950.

Williams, Robert R. 1992. Recognition: Fichte and Hegel on the Other. Albany: State University of New York Press.

Wolin, Sheldon. 1961. Politics and Vision: Continuity and Change in Western Political Thought. London: George Allen \& Unwin.

Wolin, Sheldon. 1996. 'Fugitive Democracy' in S Benhabib (ed) Democracy and Difference: Contesting the Boundaries of the Political. Princeton: Princeton University Press.

Wolterstoff, Nicholas. 1994. 'Locke's philosophy of religion' in V Chappell (ed) The Cambridge Companion to Locke. Cambridge: Cambridge University Press.

Woolhouse, Roger. 1994. 'Locke's theory of knowledge' in V Chappell (ed) The Cambridge Companion to John Locke. Cambridge: Cambridge University Press. 
Yar, Majid. 2001. 'Recognition and the Politics of Human(e) Desire,' Theory, Culture \& Society 18(2-3): 57-76.

Young, Iris Marion. 1997. 'Difference as a Resource for Democratic Deliberation' in J Bohman \& W Rehg (eds) Deliberative Democracy: essays on reason and politics. Cambridge, MA: MIT Press.

Young-Bruehl, Elisabeth. 1982. Hannah Arendt: For Love of the World. New Haven \& London: Yale University Press.

Zalaquett, José. 1995. 'José Zalaquett' in A Boraine \& J Levy (eds) The Healing of a Nation?. Capetown: Justice in Transition.

Zizek, Slavoj. 1999. 'Carl Schmitt in the Age of Post-Politics' in C Mouffe (ed) The Challenge of Carl Schmitt. London \& New York: Verso. 